The pionts Thout Wh
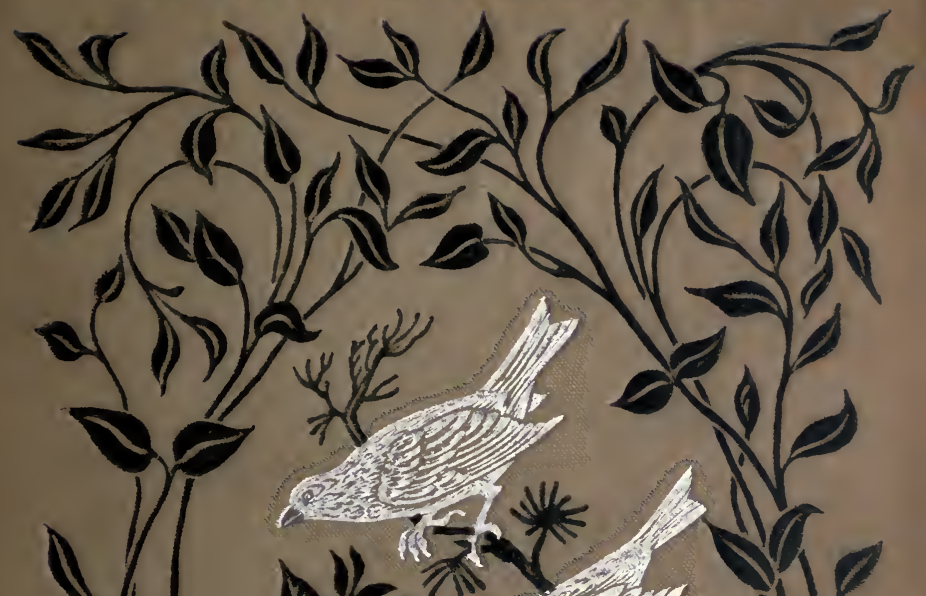


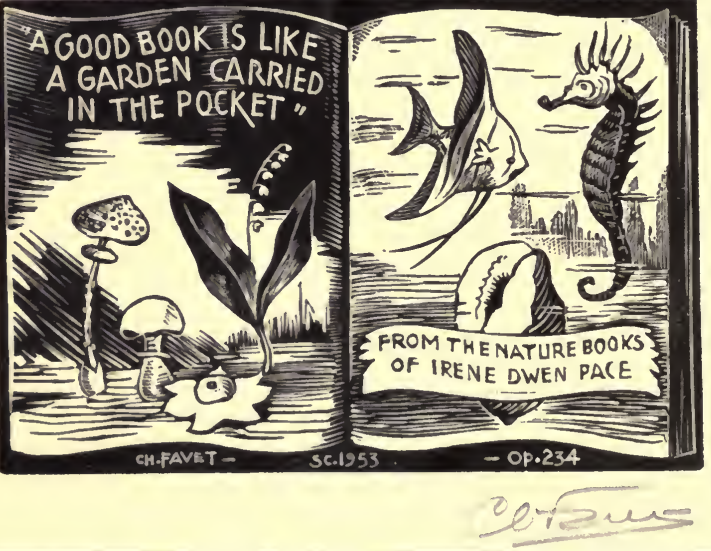









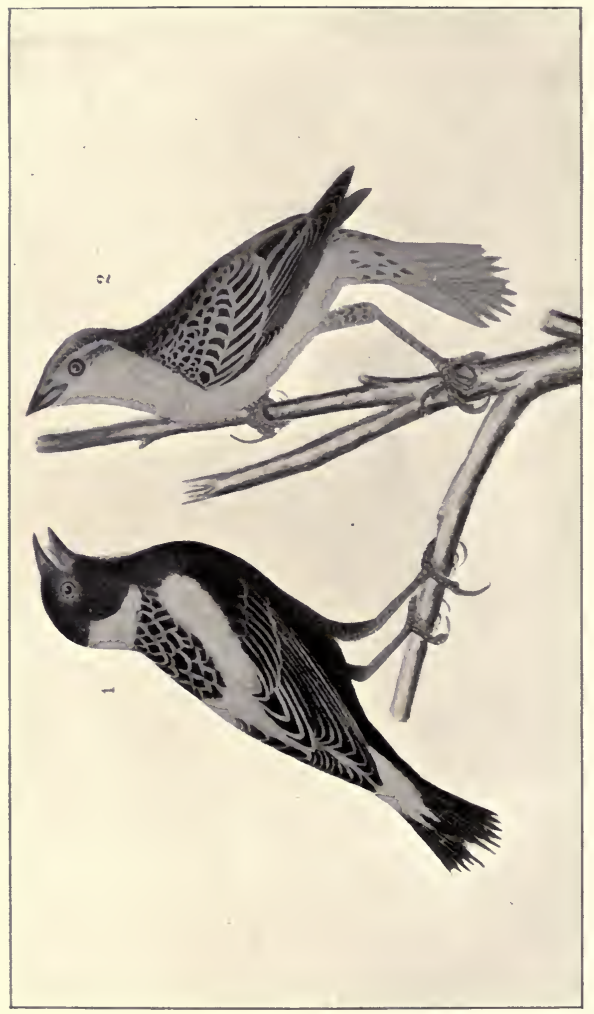

Ð0

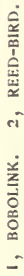




\section{The Birds}

\section{About Us}

\section{By}

Charles Conrad Abbott, M.D.

Author of Recent Rambles

Travels in a Tree-Top, etc.

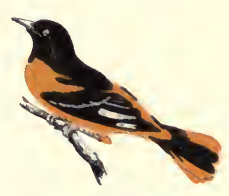

Philadelphia

J. B. Lippincott Company

1895 
Copyright, 1894 ,

BY

J. B. Lippincott Company.

Printed oy J. B. Lippincott Company, Philadelphia, U. S. A. 


\section{PREFACE TO THE SECOND EDITION.}

THE fact that a second edition of this volume is so soon required is the source of much personal gratification to the author.

The purpose of the work is twofold: to give a necessarily brief but correct idea of the variety and character of bird-life almost everywhere about us, and to rouse such an interest in our birds in the minds of readers that they will be ready to act as their defenders rather than persecutors. Until the impression is firmly grounded in the minds of young people that birds are more interesting alive than dead, and the fact is recognized by all that bird-life, as a whole, is pre-eminently useful, there will continue that criminal destruction of our feathered friends which has already proved disastrous to many sections of the country. That an era of saner views may soon be ushered in is the desire of the author.

Grateful acknowledgment is here made of many courtesies shown by the Curators of the Academy of Natural Sciences of Philadelphia to the author, while preparing the text and illustrations of the work.

C. C. A.

TRENTON, N. J., January, 1895. 



\section{CONTENTS.}

INTRODUCTION ....................... 9-2I

CH A P T E R.

THE PERCHING BIRDS.

Classification of North American birds-Thrushes-Bluebird - Blue-gray Gnatcatcher-Kinglets - NuthatchesTitmice-Tree-creeper-Wrens-Marsh-wrens and nests - Thrasher-Cat-bird - Mocking-bird: Its remarkable song-American Dipper: Its curious nesting babitsAquatic habits of land birds ........

CHA PTER II.

THE PERCHING BIRDS.-(Continued.)

Titlark-Wood-warblers: Their migratory habits: Variation of song-power-Myrtle-bird-Redstart-Maryland Yellow-throat-Chat: Its curious habits and ventriloquial power - Accentors or Wagtails-Vireos - Shrikes-Flysnapper-Cedar-birds_Swallows-Tanagers ....

CHA PTER III.

THE PERCHING BIRDS.-(Continued.)

Sparrows: Great variety of these birds: General attractiveness-Evening Grosbeak-Pine Grosbeak-Purple Finch -Cross-bills-Redpolls-Thistle or Yellow-bird-Snowbunting-Lapland Longspur-Grass-finch or "Rut-runner"-Grasshopper-finch-Sea-side Sparrows-Peabodybird and White-crowned Sparrow-Tree-sparrow-Snowbird-Song-sparrow: Its beantiful song-Swamp-sparrow: Curious habit-Foxie Finch-Chewink or Pipilo: Peculiar habits-Cardinal Grosbeak: Its splendid song -Rose-breasted Grosbeak: Its beauty of plumage and 
superb singing - Indigo-bird - Painted Bunting and "Dickcissal" . . . . . . . . . . . .

CHAPTER IV.

THE PERCHING BIRDS.-(Concluded.)

Tyrant Flycatchers-Fork-tailed and Scissor-tailed Flycatchers: Accidental occurrence in Northern StatesKingbird: Its quarrelsome disposition-Great-crested Flycatcher: Use of snake-skins in nest-building-Pewee -Black Pewee-Olive-sided Flycatcher-Wood PeweeOthers of this family-Horned Lark : Geographical races of this bird-Magpie-Jays-Raven-Crow-Fish-crow -Bobolink or Reed-bird - Cow-bird - Yellow-headed Troopial_“ Red-wings"-Meadow-lark-Orioles-Baltimore or Hang-nest-Orchard Oriole : Song and habitsRusty Grakle or Blackbird-Purple Grakle or Crow Blackbird: Enormous flocks in autumn: Their value as insect-eaters. . . . . . . . . . . 113-137

\section{CHA PTER V.}

THE GOATSUCKERS, ETC.

Whippoorwill: Its curious song and habits-Night-hawkChuck-will's-widow-Chimney-swift: Not a swallow as popularly supposed: Curious nest-building: Their great value as destroyers of insects-Humming-bird: One species only in Eastern States ........ 138-142

\section{CHA PTER VI.}

THE WOODPECKERS.

Woodpeckers: Their arboreal habits-Ivory-billed Woodpecker: One time abundant, now rare-Hairy and Downy Woodpeckers: Larva-hunters, but also insect-eatersArctic Three-toed Woodpeckers-Yellow-bellied Sapsucker: Its destructive habit, as name indicates-Black Log-cock - Red-headed Woodpecker-Golden-winged Woodpecker or Flicker: Not as arboreal as other species: Curious habit said to be true of them ....... 143-153 


\section{CH A PTER VII.}

THE CUCKOOS, ETC.

Ground-cuckoo of Southwest Territories : Curious appearance and habits-Yellow-billed Cuckoo-Black-billed Cuckoo: Invaluable as insect-eaters : Without any objectionable habits : Poor nest-builders, but excellent parents : Curious voices, hence the common name-TrogonsMotmots-Kingfisher : Common inland water-bird: Nests in the ground-Carolina Paroquet: Once abundant, now almost extinct ............. 154-159

\section{CHAPTER VIII.}

BIRDS OF PREY.

Their general characteristics and habits-King VultureTurkey-buzzard-Black Vulture-Swallow-tailed Hawk: Mississippi Kite-Marsh-hawk-Sharp-shinned and other small hawks-Goshawk-Red-tailed Hawk: Value as mousers more than compensates for poultry destroyedBroad-winged Hawk-Red-shouldered or Winter Falcon -_" Feather-boots" or Black-Hawk-Golden Eagle-Bald Eagle-Gyrfalcons-Peregrine Falcon or Duck-hawkSparrow-hawk-Osprey or Fish-hawk-Owls: Their peculiarities: Crepuscular and nocturnal habits: Also a diurnal bird-Barn-owl: Shrill voice of, when alarmed: Valuable as a mouser-Long-eared or Cat-owl : Interesting account of a colony of these birds-Marsh-owlAcadian Owl-Little Red or Screech-owl-Snowy Owl -Hawk-owl-Burrowing-owl-Pygmy-owl . . . . I60-186

\section{CHAPTER IX.}

GAME-BIRDS AND PIGEONS.

Quail or Bob-white-California Quail-Dusky GrouseCanada Grouse-Ruffed Grouse or Pheasant of Middle States-Ptarmigan or White Grouse-Prairie-chicken or Pinnated Grouse-Sharp-tailed Grouse-Wild TurkeyWild Pigeon-Turtle-dove: Curious nesting habit of dove in Arizona-Ground-dove . . . . . . . 187-197 


\section{CH A P TER X.}

THE SHORE BIRDS.

Shore birds: One time more abundant than at presentTurnbull's account of those which have become rarePhalaropes or "Coot-footed Snipe"-Red PhalaropeWilson's Phalarope-Stilt_Avocet-Woodcock : Curious courtship of this bird-Common Snipe-Robin Snipe -The Sand-pipers: Their great variety-Teeter-TiltupSolitary Sand-piper : Its nesting habits-Bartram's Tattler or Grass Plover-Peeps or Least Sand-piper-Black-bellied Plover-Golden Plover-Other Plovers-Killdeer: An inland bird-Turnstone-Oyster-catcher . . . . 198-216

\section{CHAPTER XI. \\ HERONS, RAILS, ETC.}

Herons: Their common features: One time abundant, but now less common : Nesting in colonies or "heronries"Roseate Spoon-bill-Scarlet Ibis-Glossy Ibis-Wood Ibis-Common Bittern: Its curious cry or "booming :" how produced-Least Bittern-Great and Little Blue Heron-American Egret or Snowy Heron-Green Heron or Fly-up-the-Creek - Night-heron - Yellow-crowned Night-heron-Cranes: At one time common in New Jersey, when migrating: Now never seen-Clapper-rail -King-rail: Its nesting habits-Virginia Rail-SoraYellow-breasted Rail-Purple and Florida Gallinules-

Coot. . . . . . . . . . . . 217-238

\section{CHAPTER XII.}

\section{DUCKS, GEESE, AND SWANS.}

Once much more abundant than at the present time-Quotation from Peter Kalm's travels in North America, 17481749-Swans-The Trumpeter Swan-The Whistling Swan-Wild Geese: Eight species, but two of which common on Atlantic seaboard-Sheldrakes-DucksMallard, Black Duck, and other species : Common in autumn in our larger river valleys-Wood-duck not migra- 
tory : Nests in hollow trees-Eider-duck-Surf-ducks or Scoters. . . . . . . . . . . 239-251

\section{CHAPTER XIII.}

PELICANS, CORMORANTS, AND PETRELS.

Pelican: No longer found in Middie States, but at one time common-White Pelican-Brown Pelican-CormorantsSnake-bird or Water-turkey-Petrels-Giant FulmarNoddy_Gannet-Shearwater-Mother Carey's Chickens -Albatross ... . . . . . . 252-265

\section{CHAPTER XIV.}

\section{GULLS AND TERNS.}

Familiar birds of our sea-coast and along our principal rivers and lakes: Their harmlessness, that should insure protection, but does not: Many varieties: Habits not materially different_Skuas, Jaegers, and Kittiwakes: Gull-like birds, that are strictly marine : All are scavengers-Laughing or Black-headed Gull-Herring Gull-Terns or Seaswallows-Wilson's account of nesting habits of ternsSkimmer, Razor-bill, or Cut-water . . . . . 266-276

\section{CHAPTER XV.}

THE DIVING BIRDS.

Auks - Murres - Guillemots - Puffins - Loons - Grebes :

Mostly marine species-Loons, or Divers, and Grebes also inland birds, common to rivers, creeks, and ponds-Great Auk : Now extinct-Little Auk : Lockwood's account of one kept in confinement-Puffin: Its curious box-like beak-Loon: Its strange cries: Sndden appearance on mill-ponds and rivers: Migratory-Dabchick or Devildiver: Very common ........... 277-281 



\section{LIST OF ILLUSTRATIONS.}

\section{PLATES.}

Bobolink and Reed-bird .

PAGE

Bluebirds

Frontispiece.

Long-billed Marsh-wrens and Nest . . . . . . . . 47

Parula Warblers and Nest .......... . 60

White-eyed Vireos and Nest .......... 68

Bank Swallows and Nests .......... . 77

Pine Grosbeaks and Cross-bills . . . . . . . . . . 88

Snow-buntings and Horned Larks. . . . . . . . 93

Sea-side Finches and Nest . . . . . . . . . 100

Rose-breasted Grosbeaks . . . . . . . . . . 108

Tyrant Flycatchers ............. II4

Baltimore Oriole ............. 130

Purple Grakles . . . . . . . . . . . . 136

Ruby-throated Humming-birds ......... 142

Bald Eagle . . . . . . . . . . . . 160

Duck-hawk ............... 174

Wild Turkey. . . . . . . . . . . . 187

Golden Plover and Turnstone . . . . . . . . . . 208

Killdeer Plover (Young) . . . . . . . . . 214

Spoon-bills and White Herons ......... 217

Night-herons and Nest . . . . . . . . 220

Great Blue Heron . . . . . . . . . . 228

Clapper-rail and Nest ........... 235

Loons................ . . . 279 


\section{ENGRAVINGS IN THE TEXT.}

Wood-thrush ............... 24

Robin ................ . 29

Bluebird . . . . . . . . . . . . . 31

Golden-crowned Kinglet . . . . . . . . . . 33

Chickadee .... . . . . . . . . 37

Crested Titmouse . . . . . . . . . . . 39

Brown Tree-creeper ........... 40

House-wren ............. . . 43

Brown Thrasher ............ . 49

Cat-bird .............. . 50

Myrtle-bird ............. 59

Redstart.................. 62

Maryland Yellow-throat ............ 63

Chat ................ 64

Shrike................ . . 74

Cedar-bird ................ 76

Barn-swallow ............ 80

Scarlet Tanager. . . . . . . . . . . 85

White-throated Sparrow . . . . . . . . . 98

Snow-bird ................. 100

Foxie Finch . . . . . . . . . . . . 105

Cardinal Grosbeak .......... . . . . . I09

White-crowned Sparrow . . . . . . . . . . . II2

Blue Jay . . . . . . . . . . . . . . . I22

Raven . . . . . . . . . . . . . . 124

Meadow-lark ............... 132

Nest of Acadian Flycatcher ......... . . 137

Night-hawk . . . . . . . . . . . . 139

Yellow-bellied Sapsucker ... . . . . . . 147 


\section{List of Illustrations.}

PAGR

Red-headed Woodpecker . . . . . . . . . . 147

Flicker . . . . . . . . . . . . . . 152

Yellow-billed Cuckoo ... . . . . . . . . . 156

Kingfisher . . . . . . . . . . . . . . . I57

Red-tailed Hawk . . . . . . . . . . . . . 169

Sparrow-hawk ... . . . . . . . . . . I75

Wild Pigeon ....... . . . . . . . . . I95

Woodcock . . . . . . . . . . . . . . . 204

English Snipe . . . . . . . . . . . . 205

Solitary Sand-piper . . . . . . . . . . . 208

Killdeer ....................... 2 I4

Coot . . . . . . . . . . . . . . . . 238

Whistling Swan .. . . . . . . . . . . . . 243

Golden-eyed Duck .... . . . . . . . . . 246

Pelican . . . . . . . . . . . . . . 254

Gannet .. . . . . . . . . . . . . . . $26 \mathbf{r}$

Albatross ... . . . . . . . . . . . 264

Bonaparte's Gull ............ . . . . 270

Least Tern . . . . . . . . . . . . . 274 



\section{INTRODUCTION.}

I $\mathrm{T}$ is not necessary in a book of this character to physiology of birds, important as these are to a thorough comprehension of bird-life as a whole. We will pass over, too, the subject of the relationship borne by this class of animals to the other great groups of the animate world.

It is sufficient to say that birds are known instantly by their feathers, a covering not to be confounded with any other, and peculiar to them. Birds, as we know, are creatures of flight, but so are insects and some of our mammals, and indeed, in whatever way we propose to distinguish this group from the others, it will be found that there are some exceptions to be made, but not one in the matter of the first distinctive feature that I have mentioned, that of feathers, which are beautiful in themselves because of their delicate structure, and often so exquisitely colored that they rival the richest orchids of the tropical jungle.

Feathers in some respects are so far like the hair of mammals that a close relationship in their nature has been confidently asserted; but it is now generally agreed that the true relationship is with the scales of reptiles, and this is the more probable, in that the general relationship between reptiles and birds is very 
close, and a bird away back in Jurassic time was little more than a feathered reptile.

Birds are everywhere. There is no country too cold nor any territory too hot for some of them ; and in those areas where the extremes of climate occur, it is not the apparently most rugged species only that are found: there are as many small and delicate forms as those of more sturdy build. Birds are everywhere, in a more restricted sense. They are not given to dwelling in remote spots, far from their arch-enemy, man, but come boldly into our towns, nest in our door-yards, and, as an extreme case, sparrows have been known to build in a locomotive round-house, where they were hidden half the time by steam, and compelled to excessive screeching to make themselves heard. Not all birds are as tame as this, of course, but it is safe to assert that the very wildest of them all would be less wary if man would treat them with more consideration. This has been so often demonstrated that no additional evidence need be adduced.

Man's thoughtlessness and greed have gone so far as to render extinct some of our North American birds during the present century, and others are threatened. This is often commented upon, and suggestions made to stop the work of destruction before it is too late; but nothing comes of it. Every book or essay upon birds in general, therefore, is a matter of ancient history to some extent. It is little more than half a century since Wilson, Audubon, and Nuttall wrote of the birds of this country; and now some of the species common then are gone entirely 
or are nearly extinct. To some extent this is unavoidable. The general deforesting of the country, and consequent complete change of the face of vast areas, has deprived many birds of such localities as their habits of life demanded; but in many cases these same birds would have adapted themselves to the new condition but for the inhuman persecution to which they were subjected. The phrase "there are more gunners than birds" is often literally true, and raises the question of the propriety of allowing fire-arms to be so freely carried as they are. Birds should be the wards of the general government, and not the property of the individual upon whose land they happen for the time being to tarry. This, doubtless, will never be brought about, and unless a very radical change takes place in the mind of the community, the great bulk of bird-life will soon be a thing of the past, and when too late the agricultural interests will awake to the fact that the birds were better friends than they supposed, and did better works than the insecticides that have now to be used so freely upon fruit-trees, and even annual growths. The rose-breasted grosbeak, the scarlet tanager, and the cardinal red-bird are all fond of potato-beetles; but how long would they remain unmolested if they appeared boldly in the fields? Loafers with shotguns and boys with slung-shots would quickly make way with them; and why? Because there are silly women who will pay well to put such birds upon their bonnets.

Nor can the professional ornithologist escape censure in this matter of bird-slaughter. There has 
been too much collecting by far, that has yielded nothing worth the knowing. It is not justifiable to kill a hundred warblers in a day just to see if a particular one was among them. There is nothing to be gained in determining that there are possible hybrids or, it may be, an overlooked good species found in a given area. Let what we do not know go unknown until discovered by accident, and let the birds live. Remember that it is true of every one of them, that-

He who sings and flies away

Lives to sing another day.

When we take up the subject of birds and their place in Nature, we are brought face to face with that very technical, dry-as-dust matter, their classification. It is necessary to be methodical in considering them, and particularly so when we are concerned with groups rather than individuals; but whether we begin with a little brown diver and wind up with a thrush or vice versa does not matter so much. A glance merely at technical ornithology is sufficient to show that the biologists who have closely studied birds are not quite of one mind as to the positions the various groups should have in the class Aves. Considering zoology as a whole, the most logical plan is to commence at the bottom, or lowest form, and proceed to the top, or highest form; and these, in North America, are represented by the diver and the thrush; but for personal convenience, and because the thrush is more widely known than the diver, we will reverse the plan, and starting with the birds that are the climax of avian development, glide leisure'y 
(and pleasantly, I hope) to that fag-end of featherdom, a dabchick.

North American birds, taken as a whole, are not brilliantly colored, but there is not one that is positively ugly, except, perhaps, one or more of those that live on the water, and so hardly count. There are scores that are plain as pikestaffs, like the pewee or cat-bird; but this want of fine feathers is always compensated for by a gentleness of manner, sweetness of voice, or pert vivacity, that renders these very birds more dear to us than the gaudy cardinal or reclusive tanager.

This subject of color should, perhaps, be treated in a more serious way, for it is one that has great bearing on philosophical zoology, but the reader must refer to technical works for a detailed discussion. Let me here say, however, that the most brilliant birds are not necessarily very conspicuous. In summer, with dense foliage about them, they have a knack of moving in and out among bushes and flowers in such a way that very sharp eyes are required to see them; and I have often been surprised to find that our cardinal grosbeak, in winter, is not so very showy, if there are a few yellow and brown oak leaves scattered about. When perched upon a bare twig extending from a snow-bank and whistling like a cowboy, he attracts a deal of attention naturally, but his wits are equal to the occasion, and not often does the lively sparrow-hawk surprise him. The cardinal can slide into a tangle of green brier with a celerity that only an advanced mathematician can calculate. 
Much has been written upon the instincts of birds, and a great deal of this would have been better had the authors treated of intelligence instead. Birds, of course, have instincts; so have men; but the former are not guided by them blindly, as so commonly was taught in the not very distant past. Instead, they depend upon the exercise of a faculty which in ourselves we call "common sense."

Nuttall, in the Introduction to his "Manual of the Ornithology of the United States and Canada," says, "In respect to the habits of birds, we well know that, like quadrupeds, they possess, though in a lower degree, the capacity for a certain measure of what may be termed education, or the power of adding to their stock of invariable habits the additional traits of an inferior degree of reason." This is both true and not true. They are, I hold, at least the equals of quadrupeds, and the "degree of reason" is not so very inferior. Compare, without prejudice or preconceived notion, a mouse and a sparrow, an opossum and a crow, a weasel and a hawk, and invariably you will find that the feathered is the superior of the furred creature in just this very point of what I call common sense, or, more properly speaking, cunning. The mammal when surprised is most frequently confused, and if the simplest methods of escape fail, it falls a victim, but a bird is equal in more than one way to the occasion, and by pure brain-power escapes when a merely physical effort would not avail. Birds have not been sufficiently studied in this respect. We have been content to determine the ordinary events of their daily lives, and forget that with them, as with our- 
selves, it is the extraordinary that develops what is really in us. We give full credit to the cunning fox and wary trout, because we know them so well; we admire the caution of the crow, because it is set before us continually, and drift into the belief that these are exceptional cases; but it is not so, as will be found out when we know all other creatures as well as we know those that I have mentioned. Perhaps we never will, but this is to be hoped, for such knowledge will lead to a more humane treatment of them all, even the despised worms of the dust.

It is so rarely that we meet with a person who is indifferent to birds that we may say of them that they are a necessity to our surroundings, unless pent up in town. Certainly when we walk afield and neither see nor hear them, there is a feeling of desolation that destroys the pleasure of an outing. The lusty growths of summer are not enough of themselves: they are but the set scenes of a stage whereon no actor treads; but, on the other hand, we have but to place a singing-bird in a bare bush, and we forget that there are no leaves and flowers.

Perhaps no one phase of bird-life has received more careful attention than that of migration. The word needs no definition, but the act still calls for considerable explanation. A very large proportion of the birds of this country pass their summers in the north and their winters in the south: this is called migration; but it is not a uniform matter, and the length of the migratorial journey varies exceedingly, and with some species it has materially shortened in recent years, or else the observers of a century ago 
were not so sharp-sighted as the ornithologists of today. It is not within the scope of this volume to enter into the varied details of the migration of our birds. It is a moderately uniform movement from points widely distant, and the question of a foodsupply is the principal incentive. When migration commenced, and why, cannot be determined. Geologically, probably, it is of recent date,-that is, brought about by changes wrought during the growth, climax, and disappearance of the Glacial Period; but of course all this is conjectural. We cannot conceive of migration in a climate without seasonable changes, unless an effort to escape enemies during the breeding period should induce a general exodus from the ordinary haunts; but these enemies would soon be able to follow unless a climatic bar shut them out. Coming down to details in the matter, and considering individual species rather than birds en masse, it will be found that many birds that migrate in easy stages are very deliberate, and when they find comfortable quarters remain until a change of weather warns them to proceed. This is not noticeable to any degree in the spring-tide northward journey, but is very decided in the autumn return trip along the Atlantic coast, and presumably equally true of the interior. Early or late in September, as the case may be, the woods will fill up with warblers. Even the trees along the village street and the bushes in town gardens will be visited by a throng of dainty birds, some conspicuously colored, but mostly plain and likely to pass unnoticed, unless their ceaseless activity calls attention to them. Often they do not 
even twitter, but at times some one of their number will warble snatches of a summer-tide melody, and the whole company applaud by a faint chirrupy twitter that makes the hearer think of the far-off springtime of the coming year. Now the stay of the visitors is very uncertain as to length: perhaps but for the day, possibly for more than a week, and if we have a long, dry, warm autumn, at least a fair proportion may remain even longer. I am writing now of the lower Delaware River Valley region, but the same holds good elsewhere. It is well known that one or more hardy species remain in New England all winter, and so here a great deal depends upon the weather and the food-supply as to when or how far south they go. There are others of these warblers, on the other hand, remarkably like many people we meet,-all method and without the power of novel action. They go just so far north every May, and proceed many miles farther south every autumn than there is the slightest necessity for, if it is a matter of food and warmth. They must do as their ancestors did, and anything different is something to be deplored. It is different with some others of our birds. They appear to be of an experimental frame of mind, and it is now no uncommon sight to find overstaying cat-birds, chewinks, thrushes, and a few summer sparrows that, as a rule, look up warmer quarters when the river freezes. The water-birds, too, are disposed to stay to some extent; and herons, bitterns, and rail-birds linger about the open spring-holes in the marshes, and enliven many a stretch of nut-brown meadow. But did those birds that come to us in 
spring all leave us in the autumn there would be no birdless interim; and this applies to the whole country. There is everywhere a complement of resident birds, and in autumn, too, there comes from the north a goodly supply of those birds that live the greater part of the year in the far north, but find the winters there too severe. This migratory flight is one of considerable irregularity, and often a wide extent of territory is visited for some years, every winter, by large numbers of northern birds, and then a year or two will pass and not a specimen be seen. It is a popular fancy that the appearance in unusual numbers of birds belonging to the Canadian fauna in the Middle United States portends a severe winter; but this is true only in a limited sense, if true at all. There may be severity of weather in the region forsaken, but not necessarily in the one visited. It is probably wholly a matter of food, and we can readily see that some freak in the summer weather may lessen the supply of this. Certain it is that little birds, like little boys, do not like to go hungry, and to carry the simile still further, there is practically no limit to their powers of consumption. Just as I have often eaten-in years gone by-until I could scarcely walk, so I have found birds so full that it was with much difficulty that they could fly. This has been seen in the case of robins, reed-birds, and cedarbirds. I remember, too, a lovely little chipping sparrow that lived in my yard, and which became quite tame. We fed it on crumbs until it became round as a ball, and when hopping on the path you could not see its feet. 
Birds lay eggs, as everybody knows, but not every bird builds a nest for their reception, as everybody doesn't know. The vast majority of them are nestbuilders, if we include in that term those that merely scratch a shallow pit in the ground and leave the eggs among the pebbles. This may seem a good deal like brutal indifference, but such eggs are very safe, because so hard to discover; a great deal more secure, indeed, than are those that are placed in large nests, open at the top, and near the runs and general pathways of both men and wild life. It must be remembered, too, that the birds that place their eggs on the bare ground are not able to build nests in trees, unless of so simple a pattern that they are about worthless. There is a well-known little heron that builds a nest of sticks placed criss-cross and not tied together, or at least this amount of carelessness is frequently seen; and it is not uncommon for the weak-kneed, helpless young birds to kick the structure all to pieces and be forced to sit on the nearest branch until able to take care of themselves. I have long been familiar with a heronry near my home, and have found that by reason of this insecure nest-building a considerable number of young birds come to grief. This spring-tide haunt of the little green herons is in a swampy sink-hole well grown with small birches, and the largest bull-frogs and snapping-turtles and flesh-eating creatures generally are always to be found here. Has the supply of unfortunate young herons anything to do with it ?

Of carefully-constructed birds' nests there is found, in the United States an infinite variety, but in other 
countries the art has reached a higher development. The purpose of the nest is merely to secure the safety of the eggs and young, and it is not quite clear why such very different methods should be pursued to accomplish this rather simple matter. A strong cupshaped nest, inconspicuously placed, would seem to be all that is necessary; but instead of this, we have. long pendent nests on the terminal twigs of elmtrees, and showy nests on slight shrubs, even sometimes decked out with bits of newspaper. There are swallows that build clay houses on the outside of bridges or barns where everybody can see them, instead of placing them in the nooks and corners where they would be concealed even from that arch-villain, nobody's cat. Some birds will hollow out a deep cavity in the sound wood of a healthy tree, when next door there is a natural hollow in dead wood, just as warm, as capacious, and as safely situated; and the great crested flycatcher advertises his home by hanging a snake-skin where the door-knob ought to be, if he had use for one.

There have been many learned essays written about birds' nests and a variety of conclusions reached, but it is, after all, much a matter of theory. Had there been good field ornithologists in the earliest days of bird-life and the record of the race kept until the dawn of history, a great deal would be intelligible now that must forever remain a mystery. But there is one important fact of which we must not lose sight : the fashions are slowly changing. There is one bird we call a "chimney-swallow," but these birds were about before the first chimney was built, and so lived 
a different life from what they do now, and built their nests in hollow trees instead of smoke-stacks. The purple martin is not content now unless you build a house for him, and the chances are that you will have no wrens or bluebirds about unless you provide them with suitable nesting quarters. These are all changes brought about since the days of the Indians, for certainly their mode of life was not one to attract birds, unless it was that the filth about the wigwams attracted insect-life and the birds followed it.

Having briefly touched upon some of the more characteristic phases of bird-life in general, with the expression of the hope that this volume may add its mite to the growing disposition to cultivate rather than persecute our feathered friends, let us pass to the consideration of these creatures as we find them, not only in the distant forest, but at our very doors; in the fields and upon the mountains; far from all water but the tiniest brook, and treading the sandy beaches or crowding the rocks of the sea-coast. 


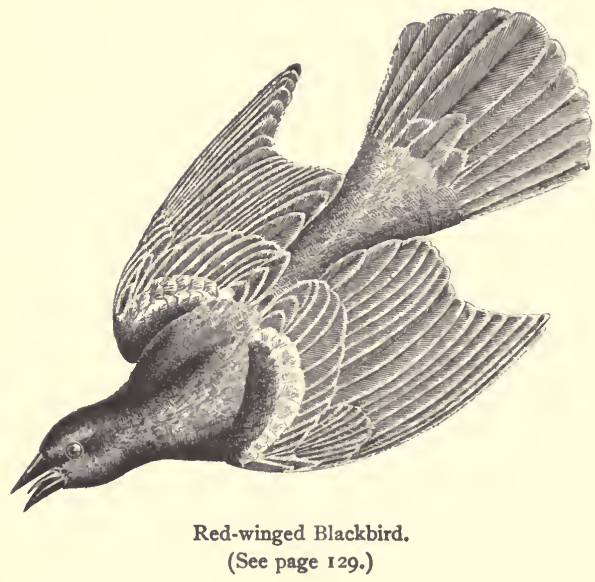




\section{THE BIRDS ABOUT US.}

\section{CHAPTER I.}

\section{THE PERCHING BIRDS.}

$W^{\mathrm{E} \text { find, on consulting Ridgway's "Manual of }}$ North American Birds," that in this country the birds have been grouped by ornithologists into seventeen orders, and these subdivided into sixty-eight genera. Each genus is made up of few or many species, and these, again, so very precise are the ornithological brethren, have been subspecied and sub-subspecied, until a suspicion arises that every man who has a cabinet of his own has represented therein a variation from normal conditions unknown to the luck of any other collector.

We do not propose to travel that far with the minutiæ champions. It will suffice for all our purposes to call a song-sparrow by that simple name, for the geographical variations are not so marked that confusion will arise, even if the reader has in his mind the sparrow of the Rocky Mountain district, that of the Delaware Valley, or the little chap that finds it in his heart to sing away off in the Aleutian Islands.

The order, last in Ridgway's proper and scientific 
series, because the highest, and first in ours, because the most interesting, is that of Passeres,- - the Perching Birds; and the leaders of this goodly company are the well-known and well-loved thrushes. However delighted we may have been with the songs of our resident birds, which in April have so much meaning, for the nesting-time draws near,-the trill of the song-sparrow, the warble of the bluebird, and the wild whistle of the cardinal,-we are apt to forget them all when for the first time, through some lone path-

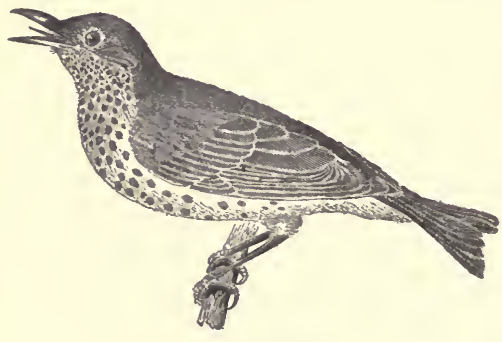

Wood-thrush.

way in the forest, floats the matchless melody of the Wood-thrush. There may be sweeter sounds the wide world over, but he is blessed that has heard this one. That this thrush is a bird of the evening, too, adds to the charm, for the song fittingly blends with the fading light; is meditative and vespertine rather than matutinal and rejoicing. But the wood-thrush sings at other times. Indeed, it seems to do little else than sing, when the matter of nesting is so far advanced as the completion of the structure, a large 
cup of sticks and grass, that has little merit beyond strength.

"The nest of this thrush is nearly as bulky as the robin's, but generally has little or no mud in its composition. It is placed upon the horizontal branch of a forest-tree, anywhere from six to forty feet above the ground, or in the forks of a sapling. The materials are twigs, coarse grasses, and dried leaves, - of which latter, in damp situations, there is often a great thickness underneath,-well combined, and lined with fine roots and grasses."-ERNEST INGERSOLL.

The early writers appear to have overlooked the sociable side of this bird, or else a change has come about in its habits during recent years. Nuttall speaks of it as "this solitary and retiring songster." As the country has been very much settled up since that author wrote, and solitudes are far less extensive, it might be claimed that the wood-thrush was more sociable now from necessity and not choice, but I do not think this the case. The bird will freely enter villages and remain throughout the season. A suitable nesting-place, if found, is very likely to be occupied, and all goes well unless the singing attracts some inhuman cur, who sets birdlime or trap and captures the unfortunate thrush. I have known this to happen and no one willing to protest against the outrage.

Another tuneful thrush is known in New England as the "Veery."

"This beautiful singer breeds from the latitude of Pennsylvania and Iowa, northward to Quebec, westward along the Upper Missouri, and in the valleys of Utah and Colorado.

"The veery makes its appearance in New England, from the south, early in May, and begins to build during the third week of that month; but in the centre of Maine the date is a fortnight later. At 
Pembina, Dakota, Dr. Coues found fresh eggs on June 9, and in Southern Colorado Mr. Henshaw took them on the rgth. Except in the far north, where its breeding is delayed until midsummer, it no doubt brings up two broods in a season. Audubon and Wilson Flagg speak of the nest as being built on mounds of sticks and grass, in the darkest part of the woods, and say that it is made to resemble the surrounding objects; while Nuttall and others write that it sometimes chooses bushes and low trees. These situations are exceptional, for the nest is almost invariably placed unsupported upon the ground."ERNEST INGERSOLL.

Quite unlike the wood-thrush, while it is content to stay all summer south of New England, it does not sing as well as when farther north. It is rather mopish, and if we had only those of the Middle States to consider, it would not be considered a success. In its habits generally the bird does not differ from the others of its family. All are insect-eaters, and this one fact should insure them freedom from all interference on our part. We hear at times of the destruction of fruit as a reason for persecution, but reasoning with people that make such remarks is useless.

Still another, a smaller but more richly-colored thrush, is the Hermit, or, as known northward, the Swamp Robin. It is thought by very many that this is our finest song-bird, and no praise bestowed by enthusiastic admirers upon it has by others been considered excessive. Its song is not unlike that of the wood-thrush, but richer, more flute-like and dreamy.

There is one point in the consideration of these brown, speckle-breasted thrushes, and that is that the difference in vocal power among individuals is very marked. While, comparing species with species, it is 
fair to class one above the other in merit, it is unquestionably true that we often find individual thrushes of one species the equals of the species considered, or, as a whole, superior. I am confident that no hermit in the wilds of Maine ever excelled a wood-thrush that for four consecutive summers nested in an appletree in my lane. Its song was more prolonged and varied than any description of such vocal efforts by Nuttall, Cheney, or other authors. This thrush differed from his fellows in another way. He came earlier in the spring, bringing a mate with him, and stayed nearly a month later. I never quite fathomed the cause, but suspect that it had something to do with the fact that the old tree was one great insectarium, and the supply of white ants, among other forms, was apparently limitless. That it was the same thrush each year was apparent; that it came early in April, mated, was significant, and I quote Nuttall to that effect:

" Conjugal fidelity and parental affection are among the most conspicuous traits of the feathered tribes. The pair unite their labors in preparing for the accommodation of their expected progeny; and during the time of incubation their participation of the same cares and solicitudes continually augments their mutual attachment. When the young appear, a new source of care and pleasure opens to them, still strengthening the ties of affection; and the tender charge of rearing and defending their infant brood requires the joint attention of both parents. The warmth of first affection is thus succeeded by calm and steady attachment, which by degrees extends, without suffering any diminution, to the rising branches of the family.

"This conjugal union in the rapacious tribe of birds, the Eagles and Hawks, as well as with the Ravens and Crows, continues commonly through life. Among many other kinds it is also of long endurance, as we may perceive in our common Pewee and the Blue- 
bird, who year after year continue to frequent and build in the same cave, box, or hole in the decayed orchard tree."

While I cannot see that the facts offered in the conclusion of the lines quoted are necessary evidence of Nuttall's inference, I bring without hesitation my wood-thrush to notice as an instance of the same bird returning to the same spot, and returning mated, which at least proves courtship prior to the northward migratorial journey, or, as I believe, permanent marriage.

Another small thrush is Swainson's, or the Olivebacked, and this, again, is one of those migrants that favor the people of the far north only with their nesting-time melodies.

"The tone of its voice is richer and rounder-more flute-like and less metallic-than that of any other of the small thrushes; but the song lacks that spiritual quality so conspicuous in the hymn-like melody of the Hermit."

The Gray-checked Thrush is rare and local, and with no marked peculiarities over its more abundant brethren.

But over all in importance, although without any of the musical charm of the thrushes we have mentioned, is the ever-abundant, omnipresent Robin. Everybody knows a robin at a glance. It is one ornithological fact that has penetrated even our large cities, and so, too, has the bird. If a tall tree happens to be in a city church-yard, the robin, when flying over, will spy it out, and accept it as a nesting-place.

"The robin is distributed in the breeding season over the whole United States, excepting the extreme south, and over the most of 
British America. Everywhere it is one of the earliest birds to nestle, and in the southern part of its range raises two or more broods in a season. In the Middle States the robins have paired by April I, and have begun to build their homes before the middle of the month. As far north as Detroit, fresh eggs are to be had the second and third weeks of April in abundance, while even on the Upper Missouri and at Puget Sound, the first broods of young are out early in June, and a second brood prepared for."-ERNEST INGERSOLL.

As everybody knows the robin, and most of us have told innumerable stories about the bird, perhaps the least said the better; but the subject cannot be passed over in positive silence. The robin is wandering rather than sys-

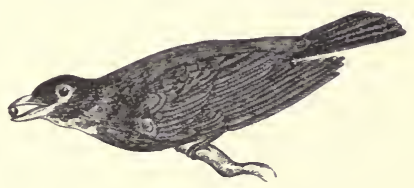

Robin. tematically -migratory. The northern birds drift southward, and those of the Middle States go farther south, but in no regular way; and if the weather is mild, they drift back in midwinter, and add their mite to our midwinter minstrelsy. The January robin is a lively fellow, and his clear, metallic chirp goes a great way towards enlivening the landscape; but this same noisy chatter in May is an intolerable nuisance.

Robins have no remarkable habits, and are patterns of propriety when keeping house and concerned with the care of their offspring. Later in the season they lead restless, wandering lives, a great many being together often, but not closely flocked as are the red-winged blackbirds. This disposition 
to remain with their own kind shows itself in the habit-not an invariable one-of roosting together in some secure, secluded, thick-set growth of small trees; at least such places have always been chosen, so far as my personal observation goes. One robinroost was on a rather steep bluff, forming at that point the bank of the river. The spot was densely covered with hemlocks and rhododendron. Here, in October and later until severe weather set in, hundreds of robins gathered about four P.M. The noise they made was quite equal to the chatter of as many crows. How early in the morning they scattered I could not learn, but almost none remained in the immediate vicinity through the day.

It has been stated that no reference to this habit appeared in print prior to 1890 , but it was known outside of books for more than a century. Probably the remarkable roosts seen in Massachusetts, where thousands of robins were congregated, is extremely unusual, but to find at least one thousand roosting in a space of less than half an acre is by no means uncommon.

The Varied Thrush, a Pacific coast robin, is so far of a wandering disposition as to have reached the Eastern States, but none have apparently taken up permanent quarters here. A new bird has little chance shown it, thanks to the extreme zeal of professional ornithologists. To demonstrate the fact that a bird was here is considered of more scientific value than to assure the public that it is here.

A thrush according to the "system" (i.e., its anatomy), but not thrush-like in appearance, is the one 


$$
x_{4}^{x}
$$



time very common, and to all people delightful, Bluebird. This bird early attracted attention, and because of its pleasing warble, bright colors, and sociable disposition became a favorite at once. Its nesting habits being recognized, boxes for its accommodation were set about dwellings, and there was probably not a farm-house in the country but had its bluebirds. What a change has taken place! Now one seldom sees these birds except as wild wanderers in the fields or forest. They come and go, even in our villages, it is true, but not as a regular feature of early spring. In the Middle States the bluebird is not migratory. They collect in considerable numbers in September, and, associated with kingbirds and orioles, seek the warm, low-lying ground, where the last of the summer's insect-life still lingers. At such a time they have much of the movements of typical flycatchers. Not long ago I watched one bird for nearly an hour. It was perched upon a tall, outreaching stake in the angle of an old worm - fence. From

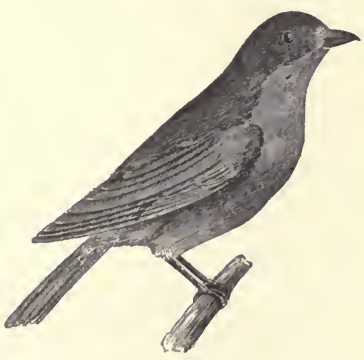

Bluebird.

this it sallied out, pewee-like, into the upper air and seized some insect, and then returned to its post. Occasionally it would fly a hundred yards or more and try some other outlook; but none other suited it so 
well, and it soon returned. Not once did it fly downward to catch an insect. Is it because it can only see a fly when the sky is beyond, and insects are not discernible against the dull background of dead grass? This bluebird, while I watched it, seemed generally to have its attention drawn upward, and only flew out in that direction.

It would seem to be a law of bird-life that the smaller the body the greater the activity. Of course our very largest birds are active enough in one sense, but it is deliberate action. I have watched vultures soar by the hour in the sky, so high above the earth that they seemed no larger than swallows, and the same is true of eagles. But this soaring probably calls for little exertion. On the other hand, there comes from the south to the Middle States, and sparingly to the north, a little blue-gray gnatcatcher that is just as active, erratic, and impetuous as any humming-bird, and is something smaller, too, than the largest of the hummers. This little bird is not generally known. It does not come to town, or, if it does, pays only a flying visit to the tallest tree-tops. It stays all summer, and builds a dainty nest of unsubstantial bits, always in a tree, and sometimes very near the top of it, and lays a few beautiful yellow-brown and white eggs.

Anent the matter of classification, this little bird used to be looked upon as a "flycatcher." It is still a catcher of flies, but, because of its bones and feathers having certain twists, "is now ranked as one of the highest types of the Oscines, or Singing-birds," and the song is usually likened to the squeak of a 
mouse, and, according to Nuttall, "scarcely louder." This is very true, so far as it goes, but there are extraordinary occasions when it can raise its voice to some purpose and squeak very shrilly. This little bird has something of a temper when nesting, and while timid as a rule, may be roused to rashness, and will dart at you as angrily as ever did the irate humming-bird.

There are two birds much alike in all respects, the Golden-crowned and Ruby-crowned Kinglets. They

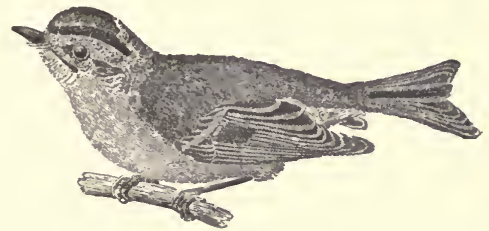

Golden-crowned Kinglet.

spend their summers in the far north, and winter, the former in the Middle States and southward, and the latter altogether far south. So it is written; but I have seen ruby-crowns at Christmas in Southern New Jersey, and occasionally elsewhere. The goldencrowned is the common one with us all the winter, and a very companionable little fellow it is. While preferring evergreens, it is satisfied with shrubbery of any kind, and will cheerfully pick its way through tangled vines, all the while singing or trying to, which is just as well, for the simple sound shows what a cheerful heart the kinglet has, and we are as quick to respond to an effort as to a great feat accom- 
plished. I doubt if, in the long run, the elaborate performances of our accomplished songsters afford more real pleasure than the less elaborated utterances of unpretentious birds. The golden-crowned kinglet occasionally leaves the trees and shrubbery in winter, and, entering unoccupied buildings, as stables, barns, and wood-sheds, goes upon a spider hunt. Whether an original conception or he took the hint from the wrens, I do not know. In general make-up and manner this bird is very wren-like, and is looked upon as one by the majority of people. A word more. This species is not a fair-weather creature; the winter of $1892-93$ was a proof of this. These birds were very common and suffered no inconvenience, although the temperature was at zero (Fahrenheit) and there was much snow. They congregated in the spruces, larches, and cypresses, and twittered as merrily as did the tree-sparrows all winter long. The kinglet is not supposed to breed south of Massachusetts, and very sparingly there. I am inclined to think that careful search would result in finding a nest now and then in the hemlock swamps of Pike County, Pennsylvania.

The ruby-crowned kinglet passes "the summer and breeding season in the colder parts of the North American continent," and while there gives abundant evidence of its superior vocal powers. The majority of our people know it, necessarily, as a pretty migratory bird, that merely twitters as it leisurely goes northward in early spring or southward in autumn. In the Middle States it is seen at its best in April. Given a warm, sunny day and plenty of underbrush, 
and the kinglets are pretty sure to be found. Then their mingled voices will ring through the leafless woodland, but not loudly.

The nests of both kinglets are huge, nearly globular affairs, made of light, flimsy material, but well knit, and so a warm home for the young. This, of course, is needed, considering the cool, damp localities chosen for a home during the breeding season. That the nests should be large, when the bird is so small, need not excite surprise when we know that many eggs are laid. In one instance eleven eggs were found in a nest, and if all hatched, the room the growing kinglets would require would be considerable.

As constituting the family Paride, tits and nuthatches, we have four of the latter and a variety, and eleven titmice, with a few varieties. Only the unmistakable species above need concern us.

The two common nuthatches are the Red- and the White-bellied. They are everywhere abundant in the Middle States from October to April, and in the summer are found northward; but single birds-old bachelors, shall we call them?-do not take the northward journey in the spring, and are seen in evergreen woods practically all summer. They are, however, outside of Canada, essentially a winter bird, and more steady, earnest, and successful insecthunters cannot be found. They are fearless, too, and often will cling to a window-sash and peck against the glass, seeing a spider or a fly on the inside. Nuttall has recorded that nuthatches, "when baffled by the slippery sleet which denies him a foothold, . . . is sometimes driven to the necessity of approaching 
barn-yards and stables." That was sixty years ago. Now the stables are as trees to the birds, and out of necessity, for sometimes there are more buildings than trees. To me these birds seem equally at home in any locality, and have but the one thought, - a sufficient food-supply. It is quite evident that the general deforesting of the country has brought about a material change of habits, especially in what we might call strictly arboreal birds.

Speaking of the red-bellied nuthatch, Wilson remarks as follows :

"This bird is particularly fond of the seeds of pine-trees. You may traverse many thousand acres of oak, hickory, and chestnut woods during winter without meeting with a single individual; but no sooner do you enter among the pines than, if the air be still, you have only to listen for a few moments, and their note will direct you where to find them. They usually feed in pairs."

Nuthatches build in hollow trees, making their own homes or using an old woodpecker's nest. Like some other birds that nest in such places, they occasionally carry sticks and grass into some hole in a rotting tree in midwinter, but do not seem to make use of the place when fitted up by them.

Of the true titmice whole volumes might be written. Emerson has immortalized one of them in verse:

"Piped a tiny voice hard by,

Gay and polite, a cheerful cry,

Chick-chickadeedee! saucy note

Out of sound heart and merry throat

As if it said, ' Good-day, good sir!

Fine afternoon, old passenger!

Happy to meet you in these places,

Where January brings few faces.'” 
Probably there is no more characteristic bird of the winter landscape of the Northern and Middle States than the black-capped titmouse, or Chickadee, as it is usually called. As I have said of the nuthatches, they have no predilections as to locality, and are as ready to glean from trees about your yard as to hunt in the depths of the woods. They are happily constituted as to food, and when one supply fails can readily turn to another, and thrive as well on vegetable substances as upon the fat larvæ of in-

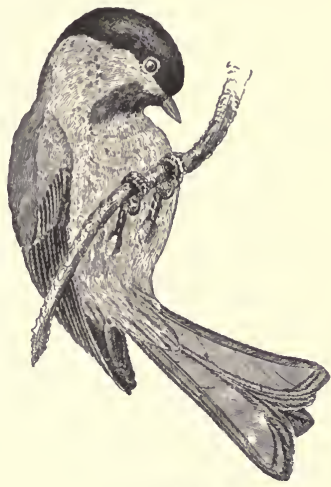

Chickadee.

sects. They are never silent. It is a matter of chick-a-dee-dee, or tsee-deet, or phe-bee, all the day long, the last of the three notes perhaps being a love-call.

Yet, common as they are, they never startle you with some strange act that makes you wonder if birds are as brainy as people. They are commonplace, and yet have such winning ways that you never tire of them. Even when they have nests in the hollows of old trees, and are concerned about their young, they do not forget to be cheerful, and sing as constantly as though care was unknown. Of all our birds, they are the tamest, I believe. I have often 
had them within arm's length, and when so near, to look at me with a curious twist of the head and expression of satisfaction, as much as to say, "I'm glad I'm not such a looking thing as that;" and well they may be.

Thoreau, under date of October 4, records,-

"The birds seem to delight in these first fine days of the fall, in the warm, hazy light,-robins, bluebirds (in families on the almost bare elms), phœbes, and probably purple finches. I hear half-strains of many of them, as the song-sparrow, bluebird, etc., and the sweet phe-bee of the chickadee. Now the year itself begins to be ripe, ripened by the frost like a persimmon."

Again, he says,-

"As I stood looking, I heard a smart tche-day-day-day close to my ear, and, looking up, saw four or five chickadees which had come to scrape acquaintance with me, hopping amid the alders within three or four feet of me. I had heard them farther off at first, and they had followed me along the hedge. They day-day'd and lisped their faint notes alternately, and then, as if to make me think they had some other errand than to peer at me, they pecked the dead twigs, the little top-heavy, black-crowned, volatile fellows."

The above tells the whole story of a chickadee's winter life, and no professional naturalist ever told it half so well.

It is to be regretted that the Crested Titmouse is not a New England bird. Emerson and Thoreau would' have made good use of it. Strangely enough, Wilson says but little about it, and Nuttall goes extensively into the matter of its song, but nothing else. In New Jersey this bird is a resident, and whatever the weather, is not to be found skulking. I have seen one clinging to the very top of a tall shell-bark in the 
meadows while it was blowing half a gale, and shouting to all the world $t$ 'sweet here! $t$ 'sweet here! I was on the point of turning homeward, but sought the lee of the hickory instead, and while the blow lasted, and through a short summer shower, the bird kept whistling, not to keep its courage up, but through excess of spirits, t'sweet here! 'tsweet here! Birds like that are a blessing.

This titmouse, being a resident, affords abundant op-

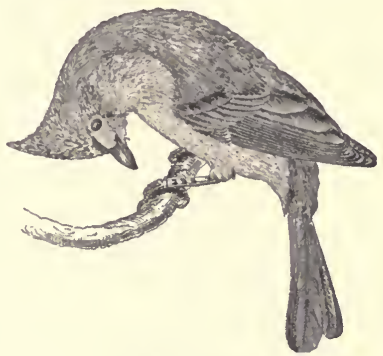

Crested Titmouse. portunity to carefully study it. As a summer bird, associated more or less with half a hundred other birds, it is not particularly prominent except when it happens to take advantage of a quiet moment and whistle so loudly that every dog within half a mile pricks up his ears.

There are several other titmice found in the South and far West, and all maintain the reputation of the group for liveliness and pluck; but not one is the superior of the crested tit of which I have spoken, nor have any of them any marked peculiarity from the general habits of the Eastern species.

A very common little bird, that because of its unobtrusive habits is not generally known, is the Brown Tree-creeper. The name, coupled with the color, describes it most accurately. As a tree-creeper we 
know it, and as nothing else. If it ever happens elsewhere than on a tree-trunk, it must be by accident. I found one once that had evidently been blown into the room through an open window during a storm. Its effort to creep over the wall was not a success, and when it finally sank to the floor, its claws took such hold upon the carpet that I could not dislodge it without injury. Any attempt to touch it was resented by vicious thrusts of its beak, which

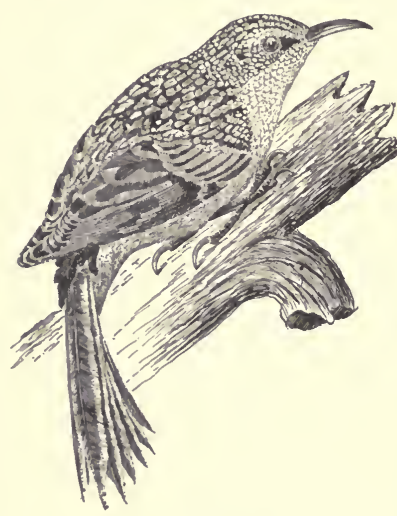

Brown Tree-creeper.

I found quite equal to piercing the skin. I had in this instance an opportunity of hearing its voice, and all I could make of it was an impatient sibilant squeak, a tsit, not unlike the hiss of a captured bat. I have never heard any other sound or attempt at singing. This bird is not unknown to the Middle States in summer, and I believe occasionally nests with us. Many years ago I found one of these birds busy about an old apple-tree, and carrying fluffy material into an irregular cavity caused by the loosening of a sheet of the bark.

There are thirteen wrens and varieties or geograph- 
ical races of nearly all of them. In the Eastern and Middle States we are pretty well supplied, and no one, I imagine, has lived in the country or in a village but what has seen and heard the common summer resident "house" or "little brown" wren. Much that was said of the bluebird can be repeated of this little bird. It was once very much more abundant than now. The imported sparrow is responsible for the sad fact. The two birds cannot or will not live together, and while a wren can thrash a sparrow in open combat, a pair of them cannot withstand the assault of a whole horde of the pestiferous foreigners.

The Wrens as a family have a good deal in common, seen as individuals, and a person who is familiar with the species on our Eastern seaboard will at once recognize the Cactus-wrens of the far West. They all have a quick, nervous, irritable way about them that is unmistakable.

The Common House-wren of the East-which has a range west to the Mississippi Valley and goes as far north as Canada, and winters in the Southern States -has been a favorite theme for ornithological writers, and the stories of its eccentricities, ready wit, and daring ways are innumerable. Its decided preference for the neighborhood of human habitations has to do with this. I doubt not it lingered about the Indians' wigwams, welcomed the earliest European settlers, and, until the introduction of the sparrow, was a fixed feature of every farm-house, and was almost as common in the towns as in the country. All it asked was a little box wherein to nest, and it paid rent therefor in musical notes. Those who have lived 
in the country must have a lively recollection of that bright, sunny April morning when, for the first time in months, they heard the cheery singing of this lively minstrel. It is always ready with a full performance. There is no tuning up, no interminable twanging of strings, or dead-and-alive tooting upon horns, but the full measure of the song proposed, and it is a welcome to spring that puts faith in the hearts of all hearers.

Year after year the same birds come to the same old quarters, and no time is lost in renovating them for the coming summer. This means work, of course, but the labor is not depressing. There goes a song along with every twig that is carried in-doors, a round of exultation with every egg that is laid, and a general rejoicing until the young have gathered strength sufficient to go out into the world. And all the while these birds are devouring thousands of insects,--literally, thousands.

I do not know how far, years ago, these wrens frequented the remote woods, but of late I have found far more in the weedy meadows, wandering about old worm-fences and making their homes in hollow trees, than about the out-buildings on the farm. Here, however, whether they felt out of place or not, they were just as lively and ready to pick a quarrel as when the lords of the door-yard. The change may not have been a sorrowful one for them, but it was for me.

The house-wren is sensitive to cold, and early in October they leave for warmer regions; but it is very difficult to make many people believe this. Time 
and again I have been assured that the wrens are here all winter, "only they don't sing," being usually added. This misconception arises from the fact that at about the time the summer bird leaves us the Winter-wren comes down from Canada and New England,

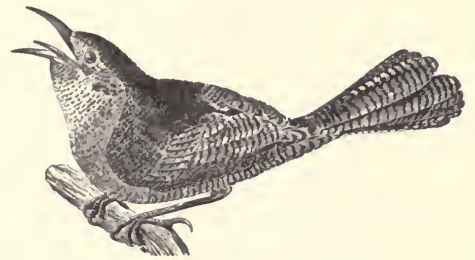

House-wren.

and stays with us until, according to some, the snowbirds go home, and it goes with them. This winterwren is a superb singer, but practically mute in the Middle States. Occasionally I have heard it warble a few rich notes, but as a general thing the bird's presence would only be known by being seen. Almost like a mouse it creeps about fences, out-buildings, and thick underbrush, uttering a sharp squeak at times when startled. A favorite winter haunt, according to my own observations, is about springs where they are surrounded by dense sapling growths and windrows of dead leaves. Among the latter it will worm its way industriously, often overturning a broad leaf of an oak to catch at any minute spider or other form of life that may be lurking there. Occasionally a severe winter makes them very bold, and they enter the out-buildings and there hunt for spiders, as does the house-wren in summer. 
Writing of the song of the winter-wren, Torrey states,-

"The great distinction of the winter-wren's melody is its marked rhythm and accent, which give it a martial, fife-like character. Note tumbles over note in the true wren manner, and the strain comes to an end so suddenly that for the first few times you are likely to think that the bird has been interrupted. In the middle is a long indrawn note, much like one of the canary's."

But if the people of the Middle States and southward are denied the privilege of hearing the shy winter-wren, we have some consolation in the fact that the Carolina wren is a resident bird, and stirs up all the quiet places, whether in the woods or on the plains, far from our dwellings or sitting on our doorsteps. The Carolina wren comes to stay, when it decides to come at all, and makes itself immediately at home; and no bird varies so much in its fancies as to locality. I have known them to occupy a boxnest in the chicken-house, filling it nearly full of sticks and feathers, and to have a cave in the steep hill-side. A huge hollow in an old locust-tree was once occupied, the birds ousting a tufted titmouse, and a corner of the hay-mow, then empty, was selected, and possession held until the rats disputed the claim.

Like all wrens, the Carolina, or " Mocker," is lively, and while it sits in one place when singing, it droops its wings and trembles all over. The song is chiefly remarkable for its clear, fife-like tone and the great variety of its utterances; but I never have found that it imitates other birds. Other birds have notes somewhat similar, and whether it is this wren or a tufted titmouse that whistles pe-to must be determined by 
the eye and not the ear. We have seen that the winter-wren sings only during nesting-time; but no such matter affects the Carolina. It is just as lively in January as in June, and I shall long remember one bitter cold morning, when a cardinal grosbeak on one side of the river, there nearly a mile wide, was answered by a wren on the opposite shore. It may have been a mere coincidence, of course, but the effect was that of giving and returning a challenge, and the clear, sweet notes of the two songsters rang out in the still, frosty air as distinctly as the cawing of the crows that filled the river valley. Nuttall gives an elaborate description of the bird's song, and speaks of the imitation of the notes of this and that bird, giving details so minutely that the thought arises, Has the habit of the bird undergone a change? Its range appears to have done so, for it is now very common in New Jersey and does not seem to stray at all. In the hills of the upper Delaware Valley, in May, 1892, I found them very abundant, and one pair at least were nesting on a shelf of rock overhung by a jutting mass of stone. It was the most open nest I had ever seen. Others of these birds were clambering in and out among the rocks, and doubtless other nests were near, but in more secluded positions.

The banks of streams are favorite localities, and I have sometimes seen the birds hop upon a muddy flat as if looking for food, but such a change is uncommon. They prefer climbing or clinging when not on the wing, and no position seems unsuitable for singing.

This bird is one of many that sing at night. Not 
merely during the twilight, but long after the sun has set and stars are visible. In the summer of 1893 I heard one singing long after twilight, while passing a dense growth of rhododendrons on the water's edge. There was no moon, and the general hush that rested over the landscape indicated that no disturbance of the locality had occurred. The notes were many, varied, and in full tone, and not the drawn-out ones that indicate the bird is singing in its sleep.

Bewick's wren is a Western species that bears a close resemblance to the Carolina, but is slightly smaller, and not nearly so fine a singer. Its general habits are about the same.

Holding prominent place among the small birds of the far West is the Cactus-wren.

Dr. Coues says of this bird,-

“The English name which the 'Cactus'-wren has acquired indicates the nature of its customary resorts, and affords a hint of its peculiar nidification. As we have already seen, several of the Arizona birds are architects of singular skill and taste; the Cactus-wren is one of them. In the most arid and desolate regions of the Southwest, where the cacti flourish with wonderful luxuriance, covering the impoverished tracts of volcanic debris with a kind of vegetation only less surly and forbidding than the very scoria, this wren makes its home, and places its nests on every hand in the thorny embrace of the repulsive vegetation. True to the instincts and traditions of the wren family, it builds a bulky and conspicuous domicile; and when many are breeding together, the structures become as noticeable as the nests which a colony of marsh-wrens build in the heart of the swaying reeds."

Probably no two small birds common to the Eastern States, and found in almost every reedy meadow, are so little known to people generally as the Marsh- 


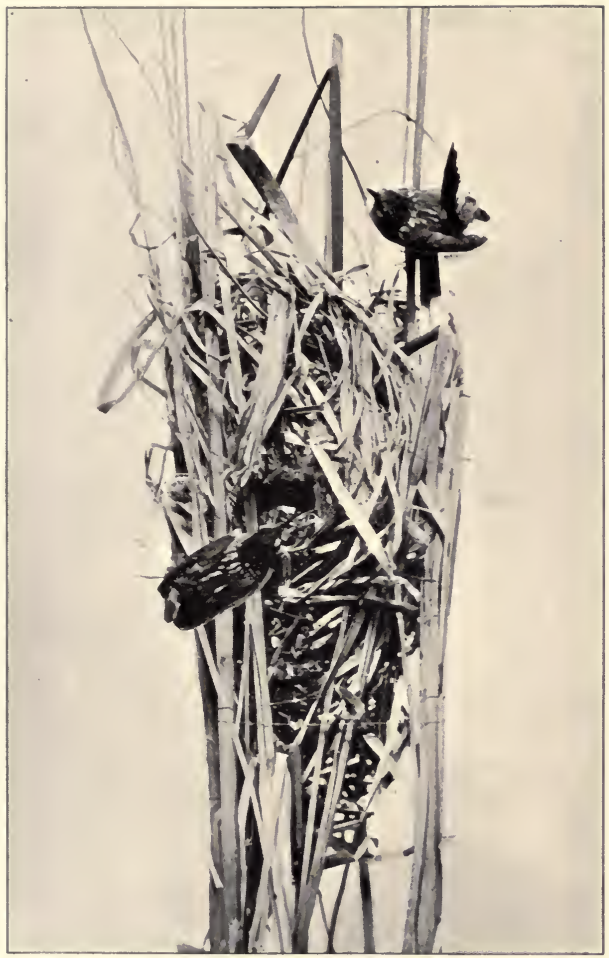

LONG-BLLLED MARSH-WRENS AND NEST. 

wrens. There are two, the long- and the short-billed species, the former being more common in the Middle States in summer, and the latter the more common in New England. In general habits they are quite alike, building nests of the same pattern. One, however, the short-billed species, lays white eggs; the other, the long-billed wren, eggs that are so speckled with chocolate dots that they appear at first glance to be of a uniform brown.

In the valley of the Delaware the marsh-wrens are abundant as far as tide-water extends, but I have not noticed them in and about the ponds above it. They may be there in abundance, however. There are three features of these wrens' lives that are prominent characteristics : they live in colonies; they build huge globular nests in reeds and bulrushes; they never leave their homes, and always half the colony sings at once, or one bird rising above the reeds gives the order, as it were, and the colony joins in the chorus.

Is it quite fair to speak of a bird's song as "contemptible," as has been done, when it is a clear, rippling note, admirably adapted to the surroundings? This little wren's voice always suggested to me that it gathered up drops of water, charged them with music, and let them trickle down the reeds.

My own observations of the nests have all been made in the same neighborhood that Wilson studied them, and now these nests lack a great deal of the mud, and of many hundreds I have found only one had a " penthouse."

It is often asserted that our climate is changing, and probably in one respect it is: we are having 
longer and warmer autumns. I think, take them as a whole, our migratory birds linger longer than formerly. I have seen marsh-wrens as late as October 4, and they were singing, too. Their stay is long enough to raise three broods, but I have no knowledge that they do.

The Brown Thrasher, which is not a "thrush," as is generally supposed, is a familiar feature of the country in the Middle States and New England during the summer, and of the Southern States in winter. It comes to New Jersey in April, and later as it proceeds northward, but is nowhere a laggard as a migratory bird. It does not worry if Jack Frost dusts its tail with salt. Having reached its chosen summer home, it immediately begins a series of rejoicings over the fact, singing songs peculiarly its own and of remarkable range, expression, and feeling. No description can give a correct idea of how it sings and what it seems to say. Nuttall correctly says, -

" His music has the full charm of innate originality; he takes no delight in mimicry, and has therefore no title to the name of Mocking-bird. On his first appearance he falters in his song like the nightingale, but when his mate commences her cares and labors, his notes attain all their vigor and variety."

I have for years listened to the best efforts of what I call the pioneer thrashers, and I could not detect a trace of faltering. There appears to be always a few in advance of the general flight, and these birds make themselves known in no uncertain way. I have seen one very early in April, when the morning was glittering with hoar-frost, perch upon the very top of a 
tall, slender birch, and while the bended twig swayed with the bird's weight and motion, this forerunning thrasher filled the whole air with melody. The united voices of the restless red-wings, the twanging of the grakle's wiry tongue, the cry of the sparrow-hawk, and the morning hymn of the foxie sparrows could not drown it. Of all spring-tide sounds, it most thoroughly puts the world in touch with the new year, with the days of budding trees and the greening of the grass.

The thrasher locates his nest in such a variety of places that it is difficult to know where to look for it, but Wilson does not mention the fact that it is very often directly upon the ground, and I have often heard the name Brown Thrasher. "ground-thrush" given to it on account of this habit. On the other hand, it is often built in a pretty elevated position. For several years a nest of this bird was rebuilt among the rank cables of a poison-ivy that covered the trunk of a large sassafras. The nest was about twenty feet from the ground. There were always two broods raised.

It is scarcely safe to speak too confidently of the character of a bird's nest, unless you hold one in your hand and describe it. The great degree of 
individuality among birds necessarily results in two things: degrees of energy and degrees of skill. Birds are no more mere machines cast in the same mould than are men, and hence arises the insuperable difficulty of giving an account of a bird's habits that every observer will find tallies with his experiences and impressions. A description so general as to do this will not be of any value to those who really wish to know something of the bird-life about them.

Everybody is supposed to know the Cat-bird, and it deserves to be known. For some unaccountable reason there is a wide-spread prejudice existing, but the birds are worth their weight in gold to every farmer; are excellent singers, and have such delight-

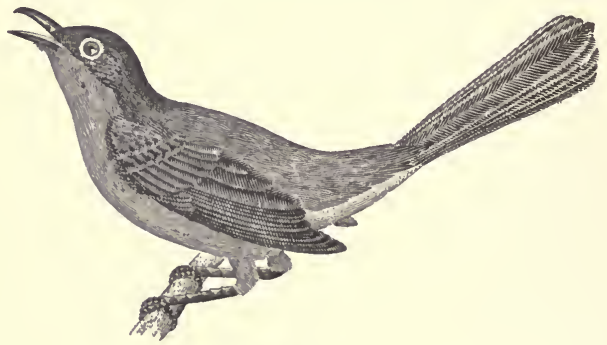

Cat-bird.

ful, pert ways, that no one, not a positive brute, can deliberately do them harm. Their habit of mewing like a cat should prejudice no one against them, for they are not cats nor cat-like, but jolly song-birds who eat enormous quantities of noxious insects and pay ten times over for all the fruit they take. I have heard 
a deal of argument about this, but every one who disputes my assertion is too lazy to prove it for himself or has not wit enough to reach any conclusion.

Cat-birds, as we have seen, are migratory. They love the sunny south, and are on their way as soon as the frosts of October dull the green meadows and paint the forest; but of late there have been some that are too lazy or have changed their mind. They linger now in New Jersey, in sheltered places, few in numbers, of course, feeding on the berries of the greenbrier. But other food is not denied them. The last I saw was scratching, chewink-like, in the dead leaves; and there is animal life among these even in the depths of winter. This overstaying catbird did not seem out of place; his fretful cry was almost musical, and the confident hop, straight and certain flight, and general well-to-do manner quite clearly evidenced that the bird was suffering no inconvenience. The winter sunshine was good enough for him, and well it might be, for he was never without company.

So much has been written about the Mocking-bird that any detailed account is uncalled for. Essay after essay have appeared in magazines; columns of newspapers have been given up to discussions concerning it, and the bird is so common in cages, that to merely name it calls up a vivid picture of this "prince of song."

In Central New Jersey this bird was a regular summer visitor fifty years ago, as I find by many references to him in unpublished records, and I have been informed that about Philadelphia, in the begin- 
ning of the century, it was almost as abundant as the cat-bird. Now it is rare. The reason for this change of habit is difficult to determine, unless it be that every one that appears is chased away or captured.

The following is W. L. Baily's admirable account of this strange bird:

"The air is soft and balmy, and possessed of a peculiar freshness which is characteristic of a pine forest. Nature here seems to have profusely spread her charms on every side, pointing us at each step to some new object of admiration. The mellow whistle of the Redbird is heard overhead, together with the call of the Jay, the soft warbling of the Vireos, the mewing of the Cat-bird, the loud, clear melody of the Wood-robin, the shrill cry of the Woodpecker, and many other voices equally attractive. As we advance into the thicket the confusion of sounds increases; every song with which we are familiar, and many more, seem suddenly let loose upon the ear; and last, though it is broad day, we are surprised to hear the cry of the Whip-poor-will. This exciting our curiosity, we naturally look around to discover the cause of so strange an occurrence; but still sounds the clear cry of 'Whip-poor-will! whip-poor-will!' When suddenly there darts up from a low bush near by a fine Mockingbird, and settling on a branch within our view, continues his varied melody. The secret is at once explained; the little mimic before us has been the sole cause of our surprise, and there he sits flirting his long tail from side to side with an air of perfect satisfaction, expanding his wings and stretching his neck in all directions, while he calls out with much animation, 'Bob-White! Bob-White!' and before poor Bob-White has time to scamper to his covey, the screams of the Pigeon-hawk are heard wild and clear; then immediately his voice falls into some soft and tender warble, gradually rising higher and higher until we recognize, among a host of others, the clear and ringing melody of the Brown Thrush, set off with the gentler tones of the Robin and Bluebird, occasionally interspersed with some fine, pleasing original notes. We stand and listen with delight to this grand concert of Nature's great musician, his voice ever changing, ever sweet, until the twilight unconsciously steals upon us; still the serenade continues. The pale moon glimmers in the eastern sky, 
and as it grows brighter and brighter and darts its vivid beams into the forest's deep recess, our little performer, as though animated with fresh spirit, seems to strain his utmost powers in pouring forth a food of the most enchanting song. This exquisite aerial music is often maintained during most of the night, or until the moon sets, two or three birds sometimes vying with each other in the strength of their voices."

It is a matter of much annoyance to find that nature has fitted the American Dipper to inhabit the mountainous districts of Western North America north to Alaska and south to Guatemala, and vouchsafed no nook or corner of eastern land a few representatives even of this strange and most interesting bird. J. K. Lord, who had abundant opportunities of observing this ouzel, or dipper, says,-

"It eschews all sociable communion, disdaining the slightest approach to a gregarious life except when mated, choosing invariably wild mountain streams, where, amidst the roar of cascades, whirling eddies, and swift torrents, it passes its lonely life.

"I once found the nest of the American dipper built among the roots of a large cedar-tree that had floated down the stream and got jammed against the mill-dam of the Hudson's Bay Company's old grist-mill, at Fort Colville, on a tributary to the upper Columbia River. The water, rushing over a jutting ledge of rocks, formed a small cascade that fell like a veil of water before the dipper's nest; and it was most curious to see the birds dash through the water-fall rather than go in at the sides, and in that way get behind it. For hours I have sat and watched the busy pair passing in and out through the fall with as much apparent ease as an equestrian performer jumps through a hoop covered with tissue-paper. The nest was ingeniously constructed to prevent the spray from wetting the interior, the mass being so worked over the entrance as to form an admirable veranda."

In the Eastern States we have nothing approaching this bird in all its peculiarities, yet there are some 
points in the nesting and other habits of well-known birds that bear a faint resemblance. Our common pewee, for instance, breeds in excessively damp places occasionally. I remember having my attention called by the miller to a pewee's nest that was so near the edge of the water-fall that it was difficult to see how it remained dry when there was an excessive flow, or when the wind was directly north. The miller told me he had seen the mist so dense that the bird was lost to sight in it going and coming from the nest. I remember, too, finding a nest on a ledge of rock, overhung by another, from which the waters of a spring were trickling. This falling water was too great in volume and the bird too large for it to fly between the drops on coming from or going to its nest.

Winter-wrens, notwithstanding the time of year, seem quite indifferent to water, and more than thrust their bills into the shallow brooks, and explore damp, dripping, gloomy caverns where all is sodden, and yet come to the light again with every feather dry and a chirp of satisfaction at their beak's end. Swallows, as we all know, do not object to a spray bath, and I have a strong inclination to believe I have seen our common spotted sand-piper deliberately dive; still, I am not sure; but enough has been seen to show that the habits of the dipper have come about quite naturally, and have nothing marvellous about them. 


\section{CHAPTER II. \\ 8}

THE PERCHING BIRDS.-(Continued.)

I $\mathrm{N}$ the Titlark we have one of those northern birds that enter the United States in autumn and remain until spring, and often until the weather is quite warm, or nearly the first of May. As a winter bird they would be a grand success if they had any music in their souls, but they have not, or, having it, let not the outside world have any intimation of the fact. A whole flock of these birds, however, tripping over the frost-bitten fields, or drifting before the wind when a gale sweeps across the meadows, is really a very pretty sight. I have often found them associated with another and far prettier so-called "lark," of which more hereafter.

In the interior plains of North America, breeding from Central Dakota north to the Saskatchewan, south, in winter, over southern plains to Southern Mexico, is found Sprague's Pipit, which is much the same bird as our eastern species in its habits.

We are now brought to consider a group of North American birds which have much in common, and yet present more variations from a common type than is usual; these little birds, and they are all small, are known popularly as Warblers. I say "known popularly," but it is a rather remarkable fact that the great mass of our people do not yet recognize them 
as a feature of our own fields and forest. It is safe to assert that a hooded or blackburnian warbler being exhibited in a mixed assembly will not be recognized by one person in five hundred; yet these superb birds are not from the tropics, but a home product.

On referring to Ridgway's Manual, we find that the Wood-warblers, known scientifically as Mniotiltide, are divided into fifteen genera, and of species there are some fifty-five, four of which straggle to Texas from the south; three are "oven-birds" or "water-thrushes," and one is the yellow-breasted chat. Of course there is an endless series in the books of "races," subspecies, and all that result of excessive museum zeal; but probably the birds that have been separated by the ornithologists are one with their brethren, in their own estimation; and certainly to him or her who in May watches a flight of warblers in the blooming orchard, it will matter little whether the blue-winged species, for instance, has a yellow chin or white. They move in the trees in the same way, lisp the same simple song, and breed among themselves, be they of the white or yellow branch of their immediate family.

As a group, the warblers spend the summer in the more northern portion of the country, and retire to warmer districts on the approach of cold weather. As they are insect-eaters, this is more or less of a necessity; and yet we have more than one species that can brave a winter of the Middle States, and they have been found in Massachusetts at this time of year, where the season is more prolonged and the average degree of cold greater. 
Warblers, viewed as to their habits, are birds of the trees, of the low bushes, of the ground, and of the water. It is seldom, then, that we can wander out of town in any direction, from April to October, and not see one or more members of the great group. But how are they to be recognized from true flycatchers, or sparrows, or greenlets? This is not always an easy matter, but there are a few points that may be borne in mind. Warblers are little birds, less rather than more than five inches in length, slender, with a narrow, sharp bill, and usually colored very conspicuously. They are warblers by name, but do not, as a rule, have any song that attracts attention; and when migrating, often merely utter a sibilant lisp that is harsh and unpleasant. The "song," of course, varies among the different species, and the birds can be recognized, in many cases, by the character of the utterance. They are all extremely restless birds, and move among the branches of the trees with so rapid a movement that identification becomes difficult, especially among those that are rather plainly colored. This quick manner indicates at once that they are not sparrows.

The number being so great, it is impracticable to give a detailed description of each, even of those that are common to our Atlantic seaboard. The first of the great migratory troupe to appear is the "Yellow Red-poll," and often, very early in April, a hundred or more will be found in an orchard or among the pines about the farm-house. They twitter rather than sing, hunt insects with tireless assiduity, remain but a short time, and leave their hunting-grounds for 
others, who find just as abundant a supply of food, if we may judge from their actions. It sometimes happens that we will see no other warblers for several days, but as May approaches the Black-throated Green Warblers make their appearance: these have a louder and rather pleasing song. But by the first of May (I am writing of Philadelphia, Pennsylvania, and vicinity) all that are coming have generally arrived, and a merry time then there is in the tree-tops. They are all very lively, and some of them decked out almost like clowns. They are yellow and black, and such make a splendid show; they are blue, black, and white, and these are as conspicuous as the bloom on the fruit-trees. There is one with an orange front that glows like a flame, and one, dearer than all the rest, of rich yellow with faint dashes of red. I say dearer than the rest, because a sweet singer, and has the good taste to remain in this favored part of the world all summer long.

"This is a very common summer species, and appears almost always actively employed among the leaves and blossoms of the willows, snow-ball shrub, and poplars, searching after small green caterpillars, which are its principal food. It has a few shrill notes, uttered with emphasis, but not deserving the name of song. It arrives in Pennsylvania about the beginning of May, and departs again for the south about the middle of September. It is a very sprightly, unsuspicious, and familiar little bird; is often seen in and about gardens, among the blossoms of fruit-trees and shrubberies; and, on account of its color, is very noticeable. Its nest is built with great neatness, generally in the triangular fork of a small shrub, near, or among, brier-bushes. Outwardly it is composed of flax or tow, in thick circular layers, strongly twisted round the twigs that rise through its sides, and lined within with hair and the soft downy substance from the stalks of fern. The eggs are four or five, of a dull white, 
thickly sprinkled near the great end with specks of pale brown. They raise two broods in the season. This little bird, like many others, will feign lameness to draw you away from its nest, stretching out his neck, spreading and bending down his tail until it trails along the branch, and fluttering feebly along to draw you after him; sometimes looking back to see if you are following him, and returning back to repeat the same mancuvres in order to attract your attention. The male is most remarkable for this practice."-WiLson.

Judged by numbers alone, the "Myrtle-bird," or Yellow-rumped Warbler, is the type of the whole group, as we see it represented in the Delaware Valley. A few are here all winter, and however

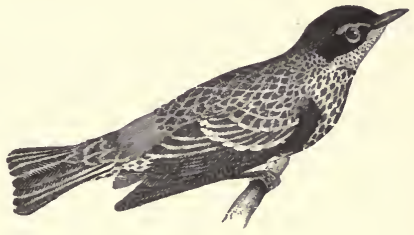

Myrtle-bird.

correct may have been the statement at the time, the remark that their spring sojourn is very brief will now no longer apply to this vicinity. They come in full force in early April, and I have seen many a dozen among the willows along the river after the middle of May; and a few appear so very early again in September that it would not be surprising if they were found breeding in the hemlock swamps of Northern Pennsylvania, but, of 'course, these early autumn birds may have come from Vermont or New Hampshire.

A conspicuously colored and unwarbler-like war- 
bler is the "Black-and-White Tree-creeping" one, that here, too, is a resident, making a neat nest on the ground, but living in the trees even more closely than most of the family. In its movements it is quite like the brown tree-creeper already noticed. This species is really quite hardy, and braves a good deal of cold, and yet is stated to be one that quickly seeks a semi-tropical climate when our winter approaches. I believe they do not all leave their summer haunts, for they are back again in April, when we are apt to have quite cold storms that do not disconcert them.

Another summer resident in the Delaware Valley, but one that varies in numbers year after year, is the Worm-eating Warbler. Its brown head with distinct darker streaks render it easily recognized, and in Southern New Jersey the Parula and Hooded Warblers tarry all summer, while more than one "Canadian" form is to be found nesting in the hemlock swamps of Northern Pennsylvania.

But to see the warblers in their glory; to hear the music they are capable of performing; to know them at their best, it is necessary to visit the woods and wastes of Canada and Northern New England. Their presence, at such a time, makes the country south of it almost commonplace. The birds of the region known as the Carolinian fauna are well enough in their way, but their united efforts do not eclipse the northern woods in the time of the nesting warblers.

There is one warbler, however, that for beauty and vivacity, and with some pretension to song, is almost the equal of the brilliant migrants. I refer to the 


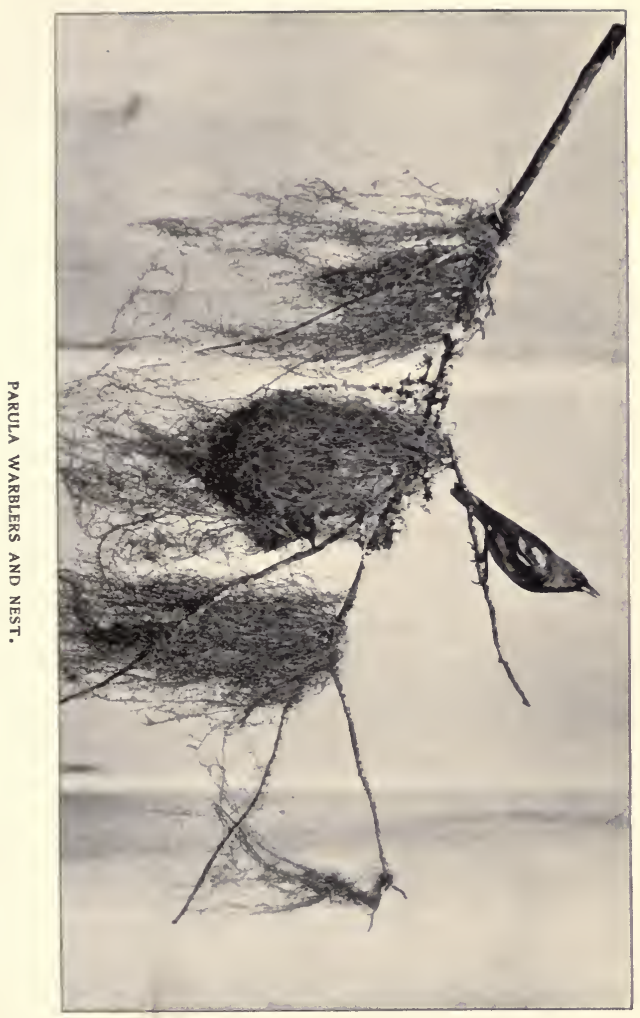



Redstart, that comes early in spring and stays until frost, and is everywhere abundant. Although a bird of the trees, it is not necessarily a shy bird and seen only away from dwellings. I have often seen scores of them in the village street. The following from Wilson will enable one to recognize this black and red-orange bird :

"This species has the constant habit of flirting its expanded tail from side to side as it runs along the branches, with its head levelled almost in a line with its body; occasionally shooting off after winged insects, in a downward zigzag direction, and with admirable dexterity, snapping its bill as it descends. Its notes are few and feeble, repeated at short intervals as it darts among the foliage; having at some times a resemblance to the sounds sic-sic-saic, at others of weesy-weesy-weesy; which last seems to be its call for the female, while the former appears to be its most common note."

All the nests of redstarts that I have found have been built in bushes overhanging the water. They are elaborate structures, and not concealed in any way; and to overcome this objection, the location mentioned may have been selected. This experience of mine in nest-hunting does not agree with Nuttall's description of the chosen spots, but he may have made his observations in a far-distant region. Certainly, to-day, the redstart has no objection even to village streets if there are trees in abundance, and I have frequently seen them in the open "squares" of Philadelphia.

The song is a pleasing tsee-tsee-tseet, with some variations, and appears to be uttered at the rate of twelve times a minute. At least this was accomplished by one individual that I watched for seven 
minutes while it gleaned the visible insects of a tall tulip-tree.

A splendid representative of the warblers that remains all summer in the Middle States, and sings rather than splutters over squeaky efforts at melody, is the Maryland Yellow-throat.

Given a piece of marshy ground, with an abundance of skunk-cabbage and a fairly dense growth

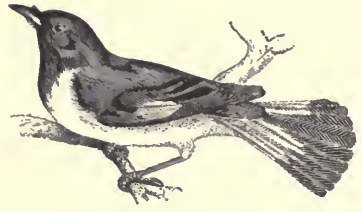

Redstart. of saplings, and near by a tangle of greenbrier and blackberry, and you will be pretty sure to have it tenanted by a pair of yellow-throats. If they are there you will quickly know it, even if you do not see them, for they are forever tswee-tee-tee, tswee-tee-tee-teeing, or, changing their tune, ask, in sweetly-warbled words, "Where did you get it?"

The yellow-throat has grown bolder since Wilson's day, and now some modifications are called for in the following by that author :

"This is one of the humble inhabitants of briers, brambles, alderbushes, and such shrubbery as grows most luxuriantly in low watery situations, and might with propriety be denominated Humility, its business or ambition seldom leading it higher than the tops of the underwood. Insects and their larvæ are its usual food. It dives into the deepest of the thicket, rambles among the roots, searches round the stems, examines both sides of the leaf, raising itself on its legs so as to peep into every crevice; amusing itself at times with a very simple, and not disagreeable, song."

If you happen to disturb the nest the "humility" 
will be found to have given way to boldness, and the wren-like habits otherwise are added to by a decided disposition to defend its own. Again, its song, of late, has a great deal of self-assertion in it, if loud, distinct utterance has any signification. I doubt if any crested tit or cardinal makes itself heard for a greater distance than travels the shriller notes of this warbler.

While I have never seen these birds in the city, they do not hesitate to go into the

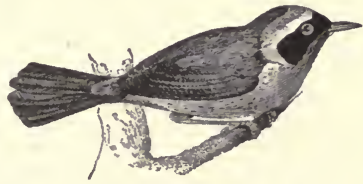

Maryland Yellow-throat. good old-fashioned gardens in the country, however near the house they may be, and are quite disposed to forage on the sunny sides of cow-sheds and stables.

I have found several nests in skunk-cabbage plants, and still wonder if they were placed there for protection, for probably no animal is disposed to touch the plant if it can avoid it; but what of the sense of smell in the birds ?

Classed as a warbler, but unlike them in every particular as we see the bird in nature, is that remarkable mimic and strange creature generally, the Yellow-breasted Chat. "The bird does not appear to winter anywhere in the United States; it breeds throughout its United States range."

According to the temperature, but never very early, in April, and sometimes not until May, does the chat appear in the Delaware Valley, and then he betakes himself immediately to a locality suited to his needs, and there he stays. They spend no days in sight- 
seeing, and leave untravelled all the tree-tops save the very few that surround the little spot they have chosen for a home. The coming is abrupt; and even if it be true that their mates come later,- - that is, the males are always in advance,- - they do not wait in silence until they are moved by the arrival of partners, but commence that strange series of cries that

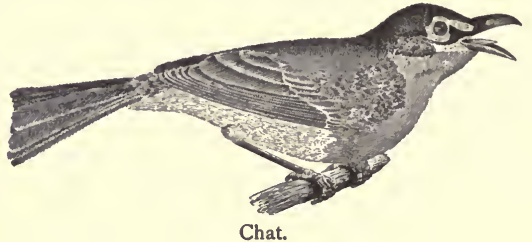

are so remarkable. If the females follow, they are either aware of where their mates are, or accept the very first bachelor they meet. For years I have been familiar with the movements of these birds, and I have never seen anything suggestive of courtship. But once mated and their married life is one long series of ecstatic demonstration. The climax of the bird's eccentricity is while the female is sitting, when he rises to a height of several feet above the nest and, with fluttering wings and dangling legs, sings a strange and never a melodious medley. These strange sounds are imitative of every distressing and harsh sound the bird has ever heard, and what adds to the weirdness of it all, it is often ventriloquially expressed. The bird has this power, and is aware of its value in deceiving any intruder. I have experimented too often with dozens of these birds not to be 
convinced of this, and it is an open question if some other birds do not also "throw their voice" with the intention to deceive. When the chat is not hovering, he sticks pretty close to the underbrush in which is placed the nest, and here and on the ground he feeds. One chat, or pair of them, that I closely watched during an entire season, did not appear ever to wander more than fifty yards from the nest, and I am puzzled to think how a sufficient supply of food could have been obtained. As insects are depended upon, they apparently only had those that wandered within the precincts of their summer home, and I never saw them in my near-by berry-patches.

The chat is a night singer. I have heard them as late as midnight, when the moon was full, in June, and as early as 3.30 A.M. the next morning, when it was rather cool and a decided fog covered the lowlands. Being astir at all hours, can it be that they wander a little more at such times and forage in areas they do not visit in daylight?

Birds far removed from typical warblers and from the chat, and yet belonging to the same great group, are the "Accentors," "Water-thrushes," "Ovenbird," and "Wagtails." There are but three species, with a far western variety of one of them. The resemblance of one to the other is pretty close, and all three are aquatic in habit, sand-piper-like in movement, and good musicians.

The "Oven-bird," so-called from the character of its earth-built nest, is much the best known of the three. It reaches the Middle States in April and lingers well on into October, if we have a series of 
those hazy, golden, dreamy days, such as our grandfathers talk of, as Indian summer and a feature of November. We have such days now, but they usually come a month earlier, and while the ripening chestnuts are being scattered by the squirrels I have heard the lingering oven-birds singing, but with no such ardor as characterizes their evening song in June; for the $t$ seé-tseé-tseé-tseé-tsé, five or six times repeated, has a good deal of music in it, when all we hear is the chirps and twitters of lazy resident birds or the chatter of blue-jays. The occasional splendid burst of song, first described, I believe, by John Burroughs, I have sometimes heard. It is as described, "clear, ringing, copious, rivalling the goldfinch's in vivacity and the linnet's in melody."

"Its nest is placed on the ground, nsually among dead leaves on an inclined surface, and though usually arched over with a lateral opening, is often of a simpler construction."

The two Water-thrushes are migratory birds, appearing in the Middle States in spring and autumn.

Let us consider these birds as we see them tripping along, either in May or September. Here we have, according to ornithologists, a warbler, but our eyes tell us it is a curious combination of a thrush and a sand-piper. They delight not only in the more quiet inland waters, but seem to have a fancy for the windtossed ripples of tide-water streams. I have watched them rush in and out, as the waves came and went along the river-shore, with all the dexterity and grace of a sand-piper. There was the same apparent unsteadiness of the legs; the same dipping of the tail 
and bobbing motion of the head. Every movement suggested an aquatic life; and while so engaged the only sound they make is a single, short, sharp chirp when alarmed. But there are occasions when all this is changed. In the early summer it finds time to leave the water's edge and go deeply into the swamps, where the undergrowth is almost impenetrable. It moves amid this tangle with the same ease that marked its progress on the pebbly beach or over the yielding mud-flat. But when in the woods it does something more than merely chirp. In an extensive tide-water swamp, where I have often found these birds, I have heard them sing, seldom in light of day, but often in the gloaming. Clear, flutelike notes in rapid succession were poured forth, then shriller and wiry ones, and these followed by a trill that slowly died away. The song is not always the same, and probably no two individuals perform it quite alike. To my hearing, it bears no resemblance to the evening song of the oven-bird. The nests of the two water-thrushes are always on the ground. and those of the short-billed species that I have seen were composed almost wholly of dried sphagnum and lined with fine grass.

A family of warbler-like birds, yet with characteristics quite their own, that are strictly arboreal, and so, naturally, insect-eaters, are the plainly colored, but neat, active, musical Vireos, or Greenlets. The facts that they are greenish-olive above and yellow or yellow-white below, and have rather stout, hooked beaks that seem better adapted than a warbler's bill for holding on to big insect game,--these points will 
enable the observer to guess pretty shrewdly, particularly if the bird in question is in the tree-tops singing loudly, even vociferously, and often launching out like a pewee to catch some passing insect.

There are three that are found here in the Middle States abundantly, - the Red-eyed, the White-eyed, and the Warbling Vireo. Warren, in "Birds of Pennsylvania," says that the Yellow-throated Vireo "breeds sparingly or irregularly in nearly all sections of the State, but is apparently much more frequently met with in the mountainous and elevated woodland regions, particularly in the northern counties, than elsewhere as a summer resident." Like many another insect-feeder, they can take to a vegetarian diet when necessity calls, and this, I think, explains why the date of departure in autumn is so irregular. Certain it is that the low-lying land along the tidewater reaches of the river does not yield to winter's onslaught as does the hilly back country, and here birds congregate and sometimes remain all winter. The cat-bird and some warblers remain; the chewink and several water-birds find a sufficient foodsupply; and what I have always insisted upon was a closer inspection of some bird-full localities that ornithologists have persistently ignored. Warren's "Birds of Pennsylvania" gives a considerable number of birds as breeding within the limits of that State not accredited to it in the general ornithologies of the continent.

The Red-eyed Vireo comes to the Middle States early in April, if the weather proves mild, and remains until the middle of October. In the autumn 


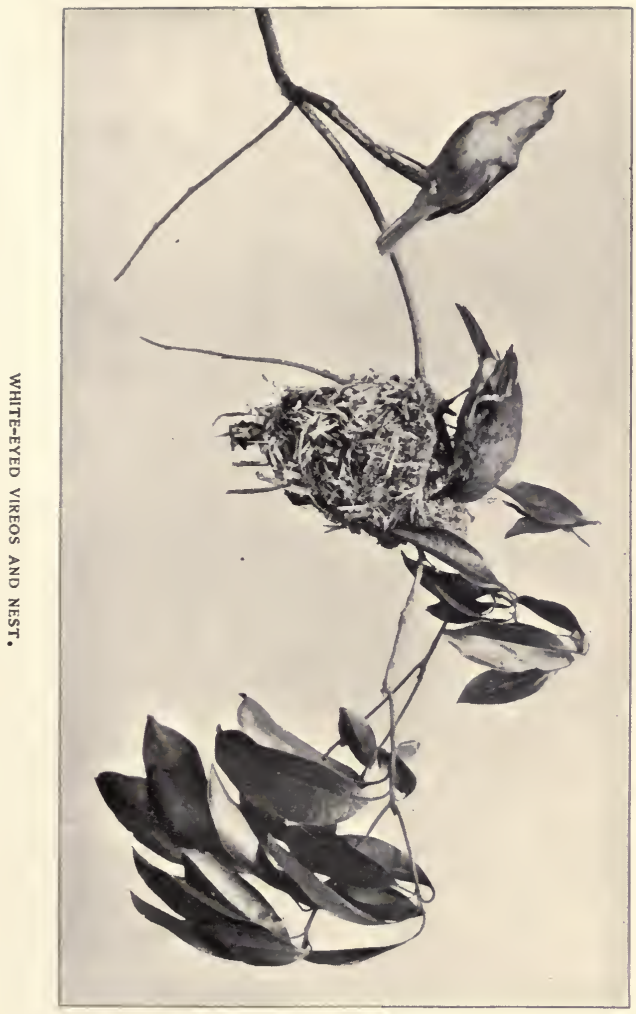



of 1893 , while I was sitting at a window in the second story of the house, one of these birds came to a maple-tree on the street not ten feet away, and there, with all the animation of an August forenoon, sang its well-known song. This was November 6, two days after a cold northeast rain-storm. But usually all the vireos are gone before the end of October.

The song of the red-eye is not readily described. It is fairly uniform as different birds sing it, and, once heard, it is easily remembered. It may be called an "up-and-down" warble, the notes being high and low alternately, and have animation or not, as the bird happens to feel. The long lists of strangelyspelled syllables given by Nuttall convey some meaning to those who have learned the song from the bird itself, but are a poor equipment if by their aid we expect to recognize the bird. Indeed, it is not the songs of birds alone that are beyond the power of a pen to convey to the minds of others. We can describe the plumage, the nest, and the eggs, but what of the spiritual part of the bird? It goes for little to say that the red-eye is an all-day insecthunter, and builds a thin-walled pensile nest in the trees, where among he spends the summer. There is an individuality that is more than all else, and yet no words can depict it. In all birds there is something that we can realize by our eyesight, but must keep to ourselves. Unless a bird is so marked as to stand out as prominently as the mountains on the plain, the chances are he will be confounded with his fellows. The red-eye is a bird of our towns, provided there be shade-trees; and though the pavements 
and fronts of the houses may reflect heat as from a furnace-mouth, the bird will hunt for every lurking fly among the leaves, and sing his strange, half-melancholy song, a part of which is lamely represented by tsheevoo tshuvee peeait peroi; this from Nuttall.

The cow-bird carefully attends the red-eyes, and deposits an egg in the nest; and the one ornithological wonder is that the bird is fool enough to take care of it. This it does almost always, although evidence of rebellion is not wanting. How the habit ever came about is a mystery, and why the red-eyes should be so patient about it is more of a one. When they have young birds they are careful to look after them and defend them when danger threatens. Perhaps the recent influx of red-eyes to our towns is to escape the cow-birds, for the latter do not appear to follow.

Very different is the White-eyed Vireo. The name indicates one of these differences, and this bird has two white bands across the wing, which are wanting in the preceding species. It is a bird, too, of the shrubbery, of tangled nooks in the country; a bird we must look for, not a town-dweller that invites us to inspect it. It comes in spring, about the same time, and makes the neighborhood lively at once. Probably there is no more energetic singer. There is not a muscle of its body not in motion, nor a feather that is not a-tremble when it fairly shouts, "Take it up easy, easy," let us hope referring to life's burden that it prophetically sees before it. Of course this is not its only song, but one of many that have a general resemblance to each other; in other words, 
are characteristic of the creature that utters them. It has all the vireonine energy and a dash of originality that make it a delightful companion. It has often been my fate to linger long in solitary places performing many a piece of distasteful drudgery, but I invariably took heart when I heard the white-eye, and held it a piece of good fortune, after all, that my daily toil took me to the haunts of so inspiriting a bird. Writes Wilson,-

"This bird builds a very neat little nest, often in the figure of an inverted cone; it is suspended by the upper edge of the two sides, on the circular bend of a prickly vine, a species of smilax that generally grows in low thickets. Outwardly it is constructed of various light materials, bits of rotten wood, fibres of dry stalks, of weeds, pieces of paper, commonly newspapers, an article almost always found about its nest, so that some of my friends have given it the name of the Politician; all these substances are interwoven with the silk of caterpillars, and the inside is lined with fine dry grass and hair. The female lays five eggs, pure white, marked near the great end with a very few small dots of deep black or purple. They generally raise two broods in a season. They seem particularly attached to thickets of this species of smilax, and make a great ado when any one comes near their nest; approaching within a few feet, looking down, and scolding with great vehemence. In Pennsylvania they are a numerous species."

Add to this the following by Dr. Coues, and you have a very complete story:

"The White-eyed Vireo has always been notable, even in groups of birds whose spirit is high, for its irritable temperament; and, during the breeding season, nothing can surpass the petulance and irascibility which it displays when its home is too nearly approached, and the fuss it makes when its temper is ruffled in this way. It skips about in a panicky state, as regardless of exposure as a virago haranguing the crowd on a street corner, seemingly at such loss for adequate expletives that we may fancy it quite ready to say, 'Thank you,' if somebody would only swear a little." 
Some years ago I suggested that the wrens had a limited profane vocabulary of their own, reaching this conclusion after watching a Carolina undergo some mishaps. This may all be a wild fancy, but there are very few birds but have expressions of anger, utterances indicative of disgust and allied emotions, and all this is but one remove from poor weak humanity.

The Warbling Vireo brings us back to town, but it must not be supposed that this bird has no other home than in the trees of our village streets. You can find them along many a country road that has, as it should have, a fair complement of way-side trees. You can find them, too, in the yards of our farm-houses, and certainly wherever there is a fine old buttonwood, planted in the days of our great-great-grandfathers. About such a tree the warbling vireo can spend its whole seven months' sojourn and have no occasion to leave it. There is, not far from Philadelphia, a buttonwood so large-thirteen feet in diameter-that a pair of these birds would require all summer to go over every twig, and two pairs might be living in its branches and not necessarily meet.

The warbling vireo comes to us in early spring without any flourish of trumpets. It has been before, and knows every nook and corner of our leafy ways. There is not a branch of any village maple, no drooping limb of any church-yard elm, no clustered trees upon the common, or stately rows of pines about our houses, but the warbler knows full well; and at home the moment he reaches us, he goes forthwith upon his musical rounds, and, gentle as a spirit though he seems, dealing death to the insect hordes that Nature 
has here, too, given a home. But we cannot think of this little bird as other than all innocence. We are interested in the murderer and not the murdered, and that makes all the difference in the world. "How shall I describe its song ?" I asked of a veteran student of our native birds. "Say it is like a distant flute," he replied, "that because of the wind we hear at brief intervals." As I listened to the bird, nearly one hundred feet above the ground, I knew what he meant, but do not expect these mere words will enable you to recognize it. It is not interrupted and out of tune like the red-eye's song, and if you hear both in the village street or on the town's outskirts, you will recognize them then, the one as troubled water flowing over rocks, the other the quiet ripple of the meadow brooks. But we at all times need sharp eyes to see these little birds. Their plumage blends admirably with the leaves that all summer long conceal these rangers of the tree-tops; and so stealthy and serpent-like is their movement, rapid though it be, that sharp eyes are needed to distinguish the bird from that perpetual game of hide-and-seek the lights and shadows play, and all the while the rippling flow of music goes on, a song that greets the gray dawn in the east and bids a fitting farewell to the dying day.

It is never pleasant to pass abruptly, or to pass at all, from the contemplation of innocence to that of crime; but, as I have intimated, there is nothing much but red-handed murder characteristic of insecteating birds' daily lives. They cover it over with music and a sweet smile for us, but this does not alter the facts one iota. These vireos are closely 
akin to the shrikes, birds of a harsh name, or butcher-birds, which is full of bloody meaning; and certainly the birds have nothing to commend them. They are not pretty, they are not sociable, they have no song-power worthy of attention, and they do go about seeking whom, among weaker animals, they may devour.

Dr. Coues says of the two species found in the United States, -

" Matching the bravest of the brave among birds of prey in deeds of daring, and no less relentless than reckless, the shrike compels that sort of deference, not unmixed with indignation, we are accustomed to accord to creatures of seeming insignificance, whose exploits demand much strength, great spirit, and insatiate love of carnage. We cannot be indifferent to the marauder who takes his own wherever he finds it,- - a feudal baron, who bolds his own with undisputed sway, -an ogre whose victims are so many more than he can eat that he actually keeps a private graveyard for the balance."

There are two of these shrikes: the "Loggerhead" comes in April to the Middle States, and northward,

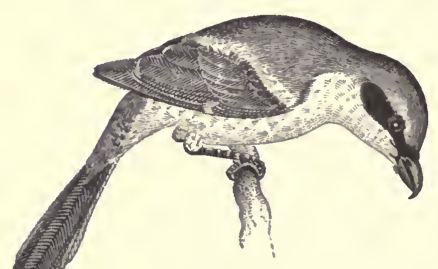

Shrike. and remains all sum mer, although not equally distributed; and in November the Great Northern Shrike comes down and stays until April, so we are never without one or the other of them. Did they not kill small birds we would have no com- 
plaint against them, and as it is, this is quite unreasonable, for small birds will kill each other rather than be incommoded, and a state of perpetual warfare is only avoided because of lack of weapons and strength.

The ordinary utterances of the shrike are harsh and thoroughly disagreeable, fitting with the general character of the bird, but it has one faculty that shows the bird has a pretty high degree of intelligence, that of imitating the cries of birds in distress, and when, responsive to this, a number are gathered together, to choose a victim. This is a degree of cunning that always excites my admiration.

Sandwiched between the shrikes and the cedarbird-and what a difference there is between them!is a far southwestern and Mexican bird to which Dr. Coues has given the name of Crested Shining Black White-zinged Flysnapper. I saw this bird in July, 1890, near Bisbee, Arizona, and the brief glances that I had made me think of the bird as one. that would be a great addition to any avifauna. It sang with much effect, caught flies with admirable grace, and looked so princely in its shining suit that I could but wonder that it should be content to have wandered into such a heaven-forsaken region. It is said they feed "almost exclusively" on the mistletoe. Well, the mistletoe was extraordinarily abundant, and did the flysnapper only make believe to launch out after insects?

Probably there is no more marked bird in the United States than the well-known Waxwing, or, as it is more generally known, the Cedar-bird. His 
cousin, the Bohemian Chatterer, is sometimes here, but is too rare a bird to be considered. Not so the

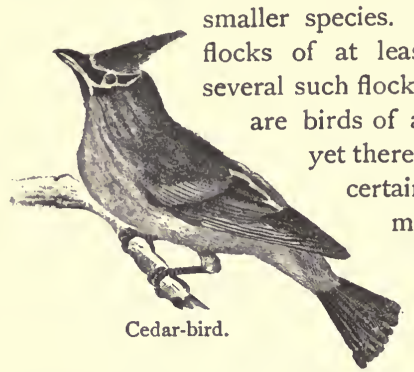

I have often seen flocks of at least a hundred, and several such flocks in one day. They are birds of all the year round, yet there is an element of unments. They are deliberate, and this impresses you at once when you see the flock leave one halting-place and seek another. They never hurry, and when they alight, the position in the tree of each one is the concern of all, and it is some moments before they get settled to their satisfaction. There must be no crowding, no ruffling of the plumage. They live forever in a prescribed suit, and never permit a particle of dust to rest upon it. Being both vegetarian and carnivorous, we look for some slight variation in their habits when they change from cherries and cedar-berries to gnats and caterpillars; but there is none. They are as neat in managing a squirming worm as a juicy berry, and never need a napkin.

Late in the summer a number of pairs agree upon some orchard or clump of wild crab-trees, and there build a "somewhat flat and rather bulky nest, composed of small twigs, roots, grasses, bits of string, feathers, or other soft materials." The nesting duties over, the young and old return to their lazy ways, 


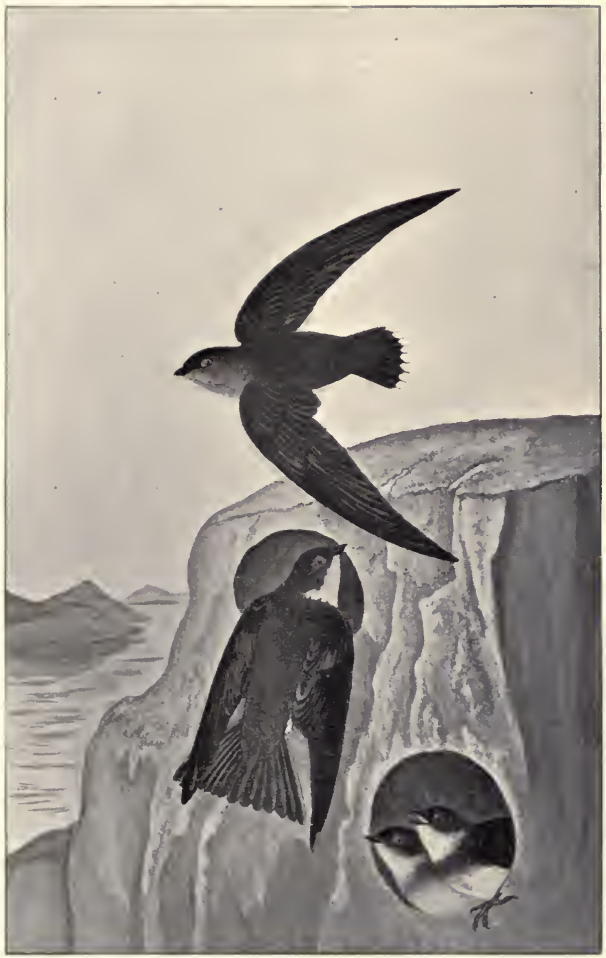

BANK SWALLOWS AND NESTS. 

for of all our birds, there is no other that takes life so easily.

Of seven species of swallows, six are found on the eastern side of the continent, and only one of these, the Rough-winged, is not very common and equally widely spread over the country. The Violet-green Swallow is a Pacific coast form. It would be a difficult matter to say of the Martin, Cliff, Barn, Whitebellied and Bank Swallows which is the best known. The last two as they dash through the air are one to most people, but no one ever mistakes the martin or the slender fork-tailed barn-swallow. It is not everywhere that the cliff-swallow is content to build his curious nests, which look so like squatty bottles with mere apologies of necks.

Hitherto, we have been considering the birds of trees, of bushes, or of the ground, but now it is literally the birds of the air. A swallow loses its identity when it rests; even the long rows that we see perched upon the telegraph-wires, although an airy perch, are out of place. Their long slender bodies and projecting wings lose all their grace when the bird is at rest. The short legs fail to easily support the body, and we see helplessness written over them until they launch again into the air, when every forward flight, graceful curve, quick turn, and downward plunge alike exhibit, as we can see nowhere else, the poetry of motion. They twitter as they go, a gladsome, ringing twitter, bespeaking a merry heart; and this attempt at song has become so inwoven with our summer days that its loss would now be more keenly felt than the happiest efforts of a thrush or the more 
marvellously sweet rose-breasted grosbeak. A summer without swallows would be a summer with summer left out. I cannot conceive it.

A bird so common, so fearless, so completely at home in our largest towns, and ready in some instances to take advantage of the facilities afforded by man to nest securely, has necessarily resulted in the bird entering more than any other into our folklore, and as the years have rolled on strange tales have been told about them. So ready of wing are they that distance means nothing; but before this was realized, strange stories of their hibernating in the mud were abroad and very generally believed. That people should have thought this possible a thousand years ago is strange enough, but that in these latter days it should be reasserted as not impossible is one of the remarkable features of modern ornithological literature. Swallows migrate, not hibernate, and that is the whole story. Dependent upon insects for food,- - they eat berries along the sea-shore when migrating, it is said,- -and forced to capture them in the air and swallow them at the same instant,- -hence the common name?-these birds can only stay while insects last, and so migrate with something more of regularity than birds that can, if they choose, creep up our coast and follow a river valley in short and easy stages.

Wherever he comes nowadays these birds do not find accommodation. The imported sparrows have changed all that; and where we once had music, grace, and direct benefits conferred, we now have wrangling, obscenity, and injuries inflicted. The town 
sparrows and modern municipal politicians are much alike, and the world will be bettered when both are exterminated. Experiment has shown, however, that we can have martins, if we will, in spite of the sparrows. This means no greater labor than to close the boxes erected for them while the birds are gone. When they come and are given possession, they can hold their own against the pothouse politicians or sparrows. I know of instances where this has been tried, and with complete success. I know of nothing more summery, more complete in the way of birds and their music, than to listen to their few notes, which being so frequently uttered, and by so many individuals, is rather the slightly interrupted flow of sweet sounds, the momentary dying away of the æolian harp when the wind ceases for the instant.

The species known as the Eave, Cliff, or Crescent Swallow is of somewhat irregular distribution, judging from what we read, but probably there is no bird that was earlier impressed upon my attention. As long ago as 1848 there was a colony of them in sight of my home, and from I 850 to I 862 they occupied the eaves of a barn that was within the range of my earliest rambles. My neighbors all knew them as "Rocky Mountain Swallows," saying they had but recently arrived, but in an old manuscript there is a reference to these swallows as building on the "old" bridge, which was removed in $182 \mathrm{I}$, and they had been building there for several years. I am surprised that Wilson overlooked this colony, not thirty miles from Philadelphia, and more than once he was in this immediate neighborhood. The principal feature that 
characterizes this beautiful bird is the gourd-shaped mud nest that it builds. The typical nest was a symmetrical flattened oval with a "bottle-neck" entrance. I remember seeing long rows of these under the projecting roof of an old barn. That was over thirty years ago; but now there seems to be a tendency to greater simplicity, and the last nests I saw were largely without this feature. Was it omitted because no longer a necessity? It certainly was not because of a scarcity of building material. A correspondent of Warren's, quoted in that author's "Birds of Pennsylvania," refers to the entrances of some nests being from three to five inches long. On the other hand, I have found many a nest that was merely a teacup with a goodsized notch in the rim on one side.

It sometimes happens that while the cliff-swallow's colony occupy the available nesting space on the

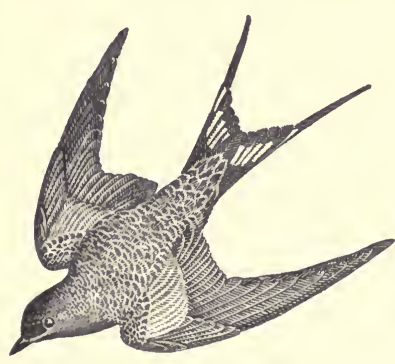

Barn-swallow. outside, more than one pair of barnswallows occupy the inside, and prettier, more graceful, and useful birds do not exist. If a person at all interested in such matters will take the pains to watch a nesting barn-swallow, he will find that the bird is most beautifully clothed, and the feathers have, as a whole, a sheen equal to that upon the throat of 
a humming-bird. Like all the others of its race, these birds come in early spring and remain until some time in September; but, whimsical creatures that they are, they have been known to debate the matter in August, and deciding affirmatively, leave then. Perhaps this early move was not strictly a migratory one, for sometimes it happens, many days after the swallows are gone,- that is, deserted their nesting-places,-they, or others, reappear and people the air, but not the old-time roosts. These, I take it, are swallows from some more northern locality.

As in all cases where birds of a kind keep together and live in so-called colonies, it is necessary that some method shall be pursued by which concerted action without confusion can be obtained, so among the swallows we find instead of an acknowledged leader, an open congress without a chairman, but where parliamentary rules are as well obeyed, if not better, than, we will say, in our legislatures. It is one of the most interesting of the annual occurrences among our birds to witness the congregating of the barn-swallows of a neighborhood in August, and see them, while perched in line on a telegraph-wire, discuss the pros and cons of departure. It is fairly safe to assume that this is their business at such a time, for they never disperse, go home, and reassemble. At least, I have never known them to do so; but then, if they always end by going, why discuss the matter for a whole day? As it may be, the whole procedure is a token of summer's ending, and though there may be, and surely will be, weeks of 
as warm and sunny weather when the swallows go, somehow the summer goes with them.

The common White-bellied Swallow is not a gregarious species. It comes to the Middle States early in April and not uncommonly in March, and keeps closely to the watercourses. It builds in hollow trees, and is evenly distributed over the country. Occasionally quite a large number will be found flitting over the marshes and flying very near the tops of the tall grasses, but generally only two or three will be noticed. Nuttall records that

“On its arrival, like many other species, it seeks out the society of man, and frequently takes possession of the mansion of the Martin. When these advantages are unattainable, it will be content with the eaves of some deserted dwelling."

They seem, in the valley of the Delaware, to content themselves with hollow trees, and the nests are very scattered. Altogether, it seems to me to be a retiring "country" swallow that cares far more for Nature than any of man's modification of it. The twitter of this swallow is quite musical, and is a pleasing addition to the sounds of the lowlands, where the swamp-sparrows and marsh-wrens hold forth so acceptably.

There is no school-boy who lives in the country, and no observing man in or out of town, but has seen some time in his life a colony of bank-swallows. Those who have not should hunt them up the first opportunity. A clay- or earth-bank with three hundred holes, and each the home of a pair of old birds, is one of the few fine showings of our ornithology, for the days of bird exhibits on a grand scale are 
almost over. My grandfather has often told me of the day being darkened by wild pigeons, and of ponds "black" with wild ducks, of the air "filled" with geese, and such strange tales even as an orchard red with tanagers. The only approach to all this is an occasional flock of perhaps one thousand blackbirds, and even a "cloud" of them of ten times that many birds. But man's interference has not yet extended to the swallows, and they make when opportunity affords a fine showing. Indeed, were it not for this feature of close association they would make no showing at all, for a single swallow is a most insignificant affair.

Great flights of swallows have been noticed in the valley of the Delaware even in November, after a long interval with no swallows in the air. At such a time they are all beating directly southward, and have a steady, direct flight unlike their summer-day progress when chasing insects as erratic in movement as they themselves are. Are such belated swallows likely to have been driven in-shore by contrary winds caught while wending their way over the ocean?

The Rough-winged Swallow is readily recognized by its dull-gray throat and the absence of the dark breast-band that characterizes the bank-swallow. The habits of the two are quite the same, except that the rough-wing is sometimes too lazy to build a nest in a bank, but will put up with some nook in an old wall, or covered corner in a bridge, or natural crevice in a rock. Those that I have seen, however, were associated with the foregoing and had nests precisely like them. The two were so intimately asso- 
ciated that it took excellent eyesight to determine which was which, as they darted about in the open space that extended from their nests to the opposite shore of the wide expanse of water.

In the Tanagers, which have, so far as habits go, absolutely nothing in common with swallows, we have a small family or group-so far as the United States is concerned-of gaudily-colored birds of moderate size. The true home of these birds is in Central and South America, and the few that we have within our limits are by no means the best examples, if guided by mere brilliancy of color. One, the Blue-headed Euphonia, is but a visitor to Southern Texas, if that, but there is no question about the others. The Hepatic Tanager of Arizona and New Mexico is scarcely known except to the professional ornithologist, but the Scarlet Tanager and Summer Red-bird are known to most people; the former migrating into New England, the latter seldom venturing beyond Southern Pennsylania. In the extreme Western States, going north into British Columbia, is the Louisiana Tanager. This is a beautiful black, yellow, and red bird; but the Eastern ones are no less gayly colored; the summer red-bird being of a uniform red; the tanager, scarlet, with black wings and tail. Forty years ago the summer red-bird was a regular visitor to Central New Jersey, coming in May and remaining until October. They were birds of the orchard, and as such I well remember them. Wilson speaks of them in a rather cold, unenthusiastic way, as if the journey into Jersey from Philadelphia was too much trouble: even if sight of the red-birds did reward it: 
“In Pennsylvania they are a rare species, having myself sometimes passed a whole summer without seeing one of them; while in New Jersey, even within half a mile of the shore opposite the city of Philadelphia, they may generally be found during the season.

"Its manners, though neither its bill nor tongue, partake very much of those of the Flycatcher; for I have frequently observed both male and female, a little before sunset, in parts of the forest clear of unilerwood, darting after winged insects, and continuing thus engaged till it was almost dusk."

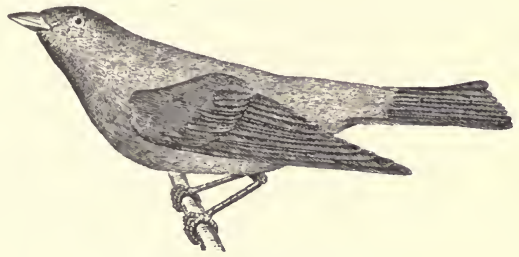

Scarlet Tanager.

I do not know how abundant the summer red-bird may be in the Southern States, but as a bird of New Jersey we have now to speak of it in the past tense rather than the present. It was a bird of our orchards forty years ago, but is such no longer. The few that wander this far north now constitute no distinct feature of the blossoming orchard. It is said-which goes for very little-that the scarlet tanager has slowly taken its place. If so, it is a poor exchange. The good old-fashioned summer red-bird was a songster of that emphatic kind which appeals to young people. He whistled with a vim. I fancy I can hear them still, when of a bright May morning their shrill voices sounded wet-WET-WET, clear as a fife, and the housedog would look as if some one were calling him, and 
my grandfather would remark, "The red-bird says 'wet,' so it's going to rain." Of course it did not rain that day; it never does when the May day is as bright as those that made the world beautiful when I was a boy. Then the orchard in full bloom and every blossom blushing as a rose! Have the flowers faded within forty years? Why have the new orchards such a pallid face? The world is forever moving forward; we are now in the electric age and steam is slow. A vast improvement, it is said, but I would that our young orchards were old and every tree had its red-bird.

I did not and do not purpose speaking slightingly of scarlet tanagers, but it must be confessed that if you took away a few red feathers there would be absolutely nothing left. As a song-bird you cannot name a more melancholy failure; and as they do not show themselves more than is necessary, and are sluggish creatures at best, why not set up bits of red flannel in the trees and call them red-birds?

As an insect-hunter the scarlet tanager is a grand success, and for this alone he merits endless praise. Here are three lines from a recent newspaper which mean a vast deal :

"In Burlington grub-worms and mice did some harm, more so than during the past twenty-five years."

Not long ago I passed, early in May, a ploughed field and noticed on the brown earth here and there a bright-red dot. Stopping by a little cedar that concealed me from their view, I saw at second glance that the red dots were tanagers, and with my field- 
glass to aid me counted sixty-three, and every one I think was busy grub-hunting. These birds were migrating northward, but had stopped here to feed, and the man who owned that field was highly favored; and yet I venture to say that if any loafer had happened along with a gun and killed a dozen or more of these birds, the owner of the field would not have entered a protest. It is this culpable indifference on the part of so many farmers, and a fancy that the birds take too much fruit, that causes them to cry out in despair that the grubs are too much for them and farming doesn't pay, and all that twaddle. Per contra, I knew a bird-loving farmer who persistently took the law in his own hands and personally arrested every bird-shooter, and thrashed them in advance of arrest, and the result was his door-yard even was full of singing-birds, and people came from the town to hear and see them. This has been preached by others since the beginning of the century and has done but little good; but I, for one, shall keep on preaching. "But we have plenty birds," says one, "in spite of the gunners." Very true, but not as many as we did have, nor as many as we might have; and the grubworms we have more than ever in spite of Parisgreen and London-purple. What we want now to know about birds does not call for the shot-gun. Our museums are overstocked and the amateur collector is a nuisance. 


\section{CHA PTER III.}

THE PERCHING BIRDS.-(Continued.)

SOME one somewhere has referred to our country $S$ as one much be-sparrowed. If this remark referred to the nuisance of our city streets, it might well be said to be overmuch be-sparrowed; but as a class, and placed where Nature purposed them to be,- - the sparrows, buntings, finches, and grosbeaks that go to make up the group known as Fringillida, -these birds are a delight, and being harmless-but all birds really are-and many of them excellent musicians, their places would be sadly missed did they forsake our fields and meadows, our gardens and door-yards, our woodlands and the sandy shores of the resounding sea. Sparrows of one or more species everywhere abound, and the sun shines more brightly, the flowers are fairer, the grass greener, the very air balmier, because of their presence. Nor are they fair-weather friends only. There is no midwinter day too arctic for a slate-colored snow-bird. or possibly, even as far south as the Middle States, a snow-flake or a long-spur; and whatever weather rages in circumpolar lands there are sparrows near at hand; and in summer at noontide, when the heat threatens to scorch the whole living world, I have heard the indigo-finch singing by the hour, and not seeking the shade of even a single leaf. We are to 


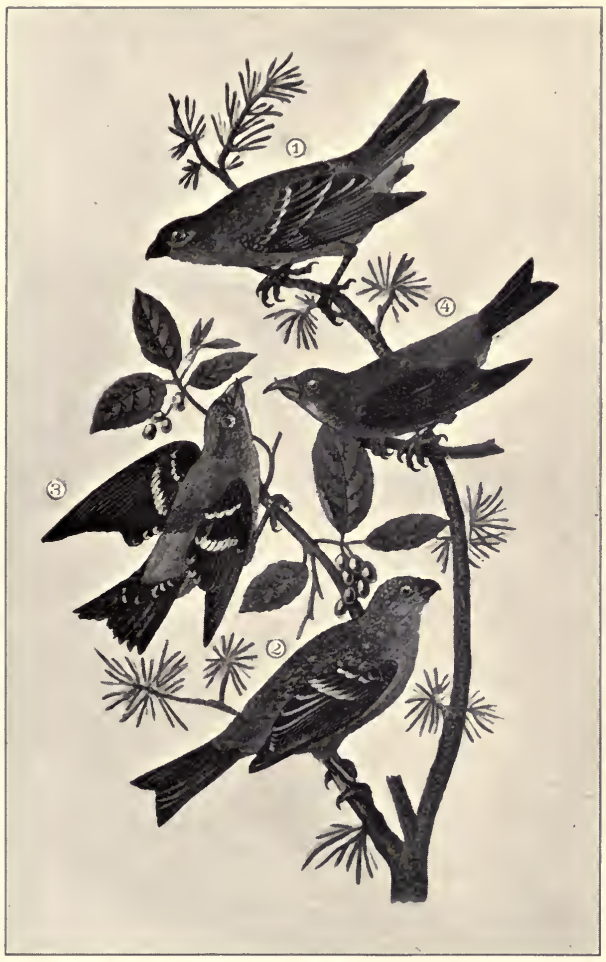

I, 2, Pine grosbeaks. 3, 4, Cross-bills. 

be thankful that we are blessed with so many sparrows of so many kinds.

Ridgway's Manual calls for ninety-two species, and, of course, of varieties and geographical races there is a goodly number. "Of these, a very large proportion are Eastern species, and their Western representatives do not materially vary in the matter of habits. Of course difference of environment causes some variation in habits, and different areas that are much alike to our eyes have some subtle peculiarities that affect the voices of the birds. More than one bird that is common to New England and the Middle States does not sing in the same way in the two localities. Again, I have heard song-sparrows, thrushes, and the rose-breasted grosbeak singing in almost a monotonous way at the sea-shore, when their songs were clear and far-reaching not fifty miles away, but at a considerable elevation, and this difference of atmosphere may be an all-important matter.

The leader of the sparrow host is the Evening Grosbeak, which has its home in the far northwest, where in comparative solitude the males warble in a manner suggestive of the beginning of a robin's song, which is saying but little in way of praise, the entire song of the robin not being remarkable as a whole, and the beginning really the poorer end of it.

Occasionally this far-off bird wanders eastward, as in the winter of $1889-90$, when numbers entered the New England States, and presumably were all killed to prevent the possibility of their return or of their remaining as residents. They were in Pennsylvania, 
too, at this time, and a good many were killed, of course.

The Pine Grosbeak, a dull-red bird with white wing-bands, is another winter visitor, and the weather has to be very snowy to bring him down very far from his native haunts. The few records I have of this bird are all connected with phenomenal snowfalls and not of the ordinary steady cold weather. This reminds me that the reading-matter in our many bird books is rather confusing. The general ornithologies say the pine grosbeak is very rare, of " accidental occurrence," and so on; but in the birdfull winter of $1889-90$, Dr. Warren records, in his "Birds of Pennsylvania," receiving forty specimens, and refers to the bird simply as "irregular." Considering the hot reception they receive, even with the temperature at zero, it is not strange that they are irregular. The wonder is that they do not learn enough to keep altogether away.

Writing of this grosbeak, as seen in the mountains of Colorado, T. M. Trippe informs Dr. Coues that

"It is very tame, frequently alighting and feeding within a few feet of one with the greatest composure. Its food seems to consist principally of pine-seeds, but it is also fond of those of the birch and alder, and occasionally descends to the ground, where it picks up the seeds of various plants and probably a few insects. During late summer and winter it has a very pleasing song,-clear, sweet, and flowing like that of the purple finch."

In the Purple Finch we have a delightful New England bird that comes into the Middle States and southward every autumn, and while here is provokingly silent, except that certain localities in Penn- 
sylvania seem to be favored with this bird as a resident.

Nuttall, writing in Cambridge, Massachusetts, says of this bird,-

"Their notes are very similar to those of the Warbling Vireo, but louder and more diversified."

As I have heard them, singly, in late autumn and even in winter, their singing was as above described, but not so loud as the vireo's song. They always appeared to me to be humming to themselves.

There are many varieties of the purple finch scattered over the West and on the Pacific coast. One of these, called the "Burion," is in some localities as semi-domesticated as the alien sparrow. Dr. Coues remarks, -

"It is a pleasing feature in the dirty Mexican settlements, which, with questionable taste, it selects as its abode, and where the air is vocal all the day long with its delightful melody."

The Cross-bills, in the Middle States, are occasional visitors in winter and residents of the far north at all times. They are red birds, without being particularly bright, and differ in that one has narrow white wing-bands. Their habits generally are the same, and in their south-bound migrations they are associated; but the white-winged species is less abundant. The common name at once describes the bird's most striking feature, and is the explanation of certain habits that are so very like the parrot's. They are altogether boreal birds, and maintain their reputation as lovers of the northern regions by nesting in winter and migrating northward as soon as the young can fly. 
They are found (the Common Cross-bill) in Pennsylvania all the year round, but only in a mountainous region. Occasionally a large flock will appear in the valley of the Delaware in the winter and scatter among the evergreens in the villages; but as soon as seen the village paper reports them, and that means waging a war of extermination.

The true Linnets, or Redpolls, are other arctic birds that occasionally come well southward if there is a severe winter, and it has been that this even was not essential to bring them. It is said to be a pretty common and regular winter visitor to Northern Pennsylvania. Probably much depends upon the character of the woodland tracts. I believe when our upper Delaware Valley had its original pine and hemlock forest that a great many of these "irregular" and rare birds were common, and a constant feature of the winter or summer as the case might be. So far as the redpolls are concerned, I have seen flocks of from fifty to a hundred suddenly come upon the scene, and then after a brief stay mount upward and make off, not to be seen again perhaps all that winter. If it is correct that they are regular visitors to Pennsylvania, it is not strange that occasionally a flock should wander to the Delaware Valley, not more than one hundred miles away.

At last we come to a common and common-sensed bird that not only lives where the bulk of humanity does, but stays about all the year round. If you have the courage to go into a snow-clad field, where a few seed-bearing bushes and rank grasses project beyond the glittering plain, it is not improbable that you will see a few dusty yellow and blackish birds 


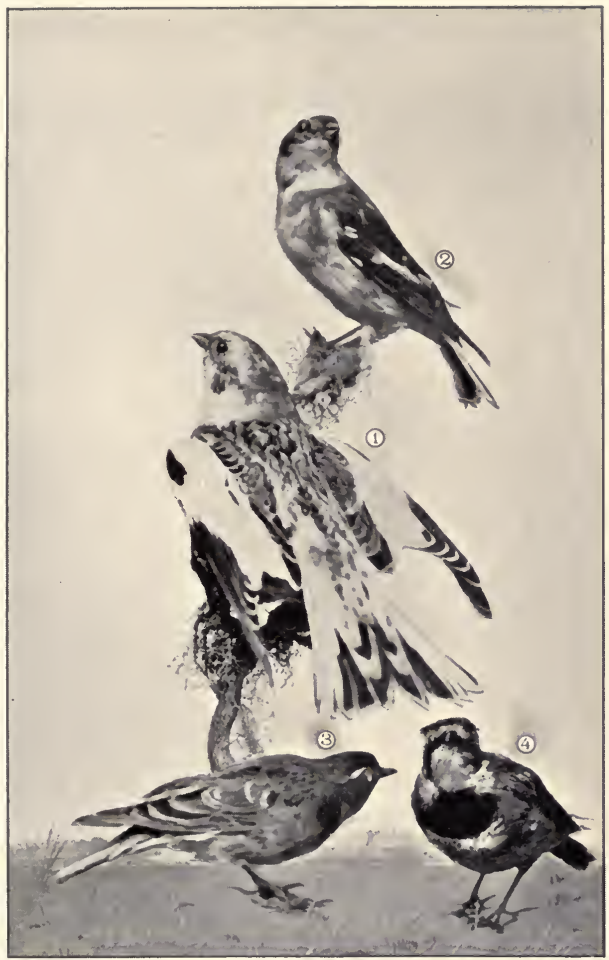

1, 2, SNOW-BUNTINGS. 3, 4, HORNED LARKS. 

swaying on the slenderest stems they can grasp, and as you approach they dart away with a wavy flight and twittering to the time of their wing-beats. Go in August to the same field, and about the same rank but now green growths you will find these same birds, but the males in less shabby clothes, having now a smart yellow and shiny black suit. Startle them and you will have the same performance,-undulatory flight and a song to match it. It is seldom that you find one alone. They have a most hearty appreciation of the merits of their kind, and often half a hundred will be found together. Given an old field with plenty of blooming thistle, and the Yellow-birds thank you for the paradise.

In autumn there comes down to us from more northern regions another of these yellow-birds, but it is never bright yellow, and when in the Middle States is as much like the preceding as two peas in a pod. It has, of course, a variety of common names, when not confounded with the common or resident species, as Pine-linnet, Pine-siskin, and Pine-finch. All these names refer to the same sort of tree, but the bird itself is really not so particular and has equal fondness for other tall trees, if they will provide it any food, and some of them appear to do so. At times, too, a huge flock of them will descend to a rank growth of weeds. A heavy snow-fall tames them, of course, and I once fed a large flock for four days with bread-crumbs, which they ate greedily; so greedily, indeed, that their husky twitter I translated as give me more, give me more.

In the beautiful Snow-bunting or Snow-flake, as 
it is sometimes called, we have one of our handsomest sparrows. It is a northern bird, and not at all disposed to wander out of New England if it can help it. Its summer home is "the circumpolar region," and yet it may be an occasional pair nest out of bounds. I well remember a superbly snowy winter day some thirty years ago, not too cold, but every object hidden by a dense mantle of feathery, clinging snow. About noon the sun shone out brightly and the landscape was too dazzling for the unprotected eye. I set forth, peering painfully under the rim of my hat, but ready to take note of any bird that came by. Before I had gone twenty paces there were birds on the stilts of the wheelbarrow, they were scattered over the few projecting stakes in the woodpile, and a host of them had gathered in the open wagon-shed. These were particularly happy, for they were eagerly picking at the bits that lay about where the carcasses of pigs had been cut up a few days before. My near presence seemed to worry them, and they gathered into a loose flock and hurried to the fields. I followed, and still recall their head-overheels flight, and remember their cheery whistling chirp. Since then I have seen but few of these birds. The winter of I 892-93 was a "circumpolar" one in the valley of the Delaware, and I am told brought a considerable number of these birds; so many, indeed, that under the name of "winter reedbirds" they were sold in the markets.

The Lapland Long-spur comes to Pennsylvania every winter where that State touches upon Lake Erie, but it does not wander beyond unless moved 
by the same influences that induce the preceding to take such a journey. Of course there always will be exceptions to such "laws" of migration. I have seen a mounted skin of a long-spur that must have been killed in New Jersey in November, and it has always seemed probable that one or more of these birds might be associated with flocks of horned larks, and so pass, unnoticed, the winter among us. This bird is said to be a fine singer. There are other long-spurs found in the far west and northwest.

The Grass-finch, Vesper-sparrow, or Rut-runner next commands attention. This is a native bird, migratory also to some extent. I have never failed to see them all winter in Southern New Jersey. In the lower Delaware Valley, where these birds are extremely common, and of course called by that wondrously comprehensive name "Chippy," I have heard the name "Rut-runner" also applied, some observing sweet-potato grower having actually noticed that this little sparrow has the habit of keeping just ahead of an approaching wagon, and, when not on the wing, "runs like a killdeer up the rut." There are few grassy fields, I imagine, where this bird is not found, and you are not likely to mistake it, for it shows two white feathers in its tail when flying. It is a ground bird the greater part of each day, and chirps when startled like any other "chippy;" but it is a master musician for all that, and, singing at or after sundown, has been aptly called the vesper-sparrow. Burroughs's "Wake Robin," which everybody should read, will tell you all about the bird, and in a way, too, that no one else can. 
This sparrow builds its nest on the ground, laying pretty white eggs with a goodly sprinkling of reddishbrown.

A group of sparrows known scientifically as the Ammodrami, includes some migratory species, and the Grasshopper-finch, that loves to twitter from the lower rails of an old worm-fence, is one of them. Seen at a little distance you might not distinguish it from some of our other and even commoner ones, but if you caught a glimpse of the bright-yellow bend of the wing you could make no mistake. What a queer little wheezy song it has! Not much louder than the squeak of a mouse, and suggestive of the grasshopper's stridulation; hence one of its common names. Like the grass-finch, it nests on the ground.

Going to the sea-coast and following the immediate shores of the rivers until the water ceases to be brackish, and sometimes where it is quite fresh but still tide-water, you will find two very interesting sparrows. The larger one and most prominent generally is the Sharp-tailed Finch, or "Quail Head," as it is sometimes called. It is a quick-motioned bird that climbs as readily through reedy growths as it flies over them, and can run with a mud-hen's speed over the mud. Nuttall says they cannot sing, but their nesting-day twitter, heard in the marshes, where we have so little music, is not so harsh as he intimates. A great deal in bird music depends upon association. After a day on the sea-shore with but the grating of a gull's cry in your ear, the lively twitter of a sharp-tailed finch is certainly refreshing. 
The Sea-side Finch is more strictly marine than the preceding, and what the sand-pipers do in the way of running and wave dodging is quite within this sparrow's capabilities; but it does more: it does its best to enliven the salt marshes by a lively little song which it hears, doubtless, but which is often drowned by the ceaseless clack and clatter of the clapper rails.

Both the sharp-tailed and sea-side finches are crepuscular, and run up and down the reeds and on the water's edge long after most birds have gone to sleep; and late at night, on the shore of Chesapeake Bay, I have heard the simple song of the sea-side sparrow.

The White-crowned Sparrow is a beautiful northern bird that comes southward in autumn and remains until spring. Along the coast-line and through the Delaware Valley they are irregular in their appearance, but less so in the interior. The greater portion continue into the strictly Southern States, and a mild winter is called for to keep them where there is likely to be much ice and snow.

The white-crowned sparrows of our Atlantic seaboard go out of the country to breed, and congregate in Labrador and Newfoundland. Here Dr. Coues found them nesting, the structure being placed upon the ground. This author states,-

"The song of this species bears a close general resemblance to that of the White-throat, but is, nevertheless, instantly distinguishable."

In the West, this bird breeds in mountainous regions. Mr. Trippe describes their song, as he heard it in Colorado, as 
" a lively, agreeable song, fine and clear, and frequently heard from a score or more of birds at once, with a most pleasing effect. While his mate is sitting, the male sings almost constantly through out the day, and sometimes even late into the evening."

The more abundant and better known Peabody. bird, or White-throated Sparrow, scarcely calls for special notice. Everybody seems to know (c) it, and to know all about it. In summer it is a New England bird, and in autumn it comes by the hundreds into the Middle States and southward. A

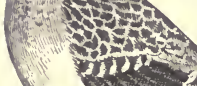
great many stay all winter in Southern New Jersey, and there are few thickets of greenbrier in sheltered places on the east shore of the Delaware River but harbor some of these birds. They are always perched on comWhite-throated Sparrow.

the sun does shine out on half a dozen in a row their whistling commences.

Very different is the active Tree-sparrow that comes down from the far north, and is so abundant in Pennsylvania and New Jersey from November until April. They are as active as the white-throats are lazy, and keep up a merry twitter while seedhunting. They are always in large, loose flocks, and when you startle one he will give a shrill alarm-cry, and a hundred that you did not see will start up out of the dead grass and weeds, and every one will sing after its fashion. This bird has ever been a favorite 
of mine, not because there is so much of him as so much of them. It is a case where one is not as good as a hundred, but just the opposite, and a hundred, fortunately, are easier found than one. Nuttall speaks of two or three singing together. I have heard a full chorus, and it is then music that makes you forget the "deadness" of the season.

Akin to this bird is the true "Chippy," the little chestnut-crowned fellow that becomes so delightfully tame. If it were not for the infernal cats that people persist in keeping about, I believe the chippies would venture in through open windows and peck crumbs from the table. This bird is the type of gentleness, and I have several times obtained its perfect confidence. To a certain extent they are migratory, coming early in spring and retiring when winter fairly sets in; but a few remain, finding some cosey nook that shelters them in severe weather; but if there is food sufficient, mere cold of itself does not seem to incommode them.

Strangely enough, many people confound the Fieldsparrow with the Chippy. They are only alike in being equally delightful. The chippy's song, so simple yet so sweet, a mere $t$ st-tst-tst-tst-tsee, the last "syllable" being long-drawn, "almost like the jingling of farthings," as Nuttall puts it, is very different in tone, volume, and animation from the clear, well-rounded te-de-de-de-de-d-d-d that rings from early morning until after sunset in our pastures. I say "pastures" rather than "fields," for the bird has always seemed to me to prefer the grass and a goodly sprinkling of weeds to cultivated acres. 
There should be a small tree or two scattered about, for the elevated perch with a commanding outlook is almost needed to induce our little favorite to put forth his best efforts.

The Field-sparrow comes early and stays late, and not a very small percentage have of late omitted the migratory flight. In May they build pretty little nests, usually just off the ground, and in Central New Jersey raise two broods.

Those that migrate do so in loose flocks, and, associated with chippies, remain in companies until it is time to return to their proper homes, their summer nesting- and resting-places.

In various parts of the country there are snowbirds that are peculiar to the areal limits they visit. Ridgway mentions seven and some varieties. Some of these are more elaborately marked than others, though none are brightly colored. All are lively, sociable little birds, and as a class are fond of each other's company, and wander in loose flocks, often containing a large number of individuals.

The Snow-bird " breeds from Northern New England northward, and on the higher hills south to

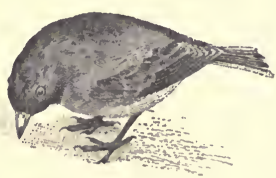

Snow-bird. North Carolina. It is an abundant summer resident" of Eastern Canada. "The song is very similar to that of the Chipping Sparrow." It usually places its nest upon the ground. My own impression of the song is that it is sweeter and more elaborate than that of the chippy. On April 6, I 879, I 


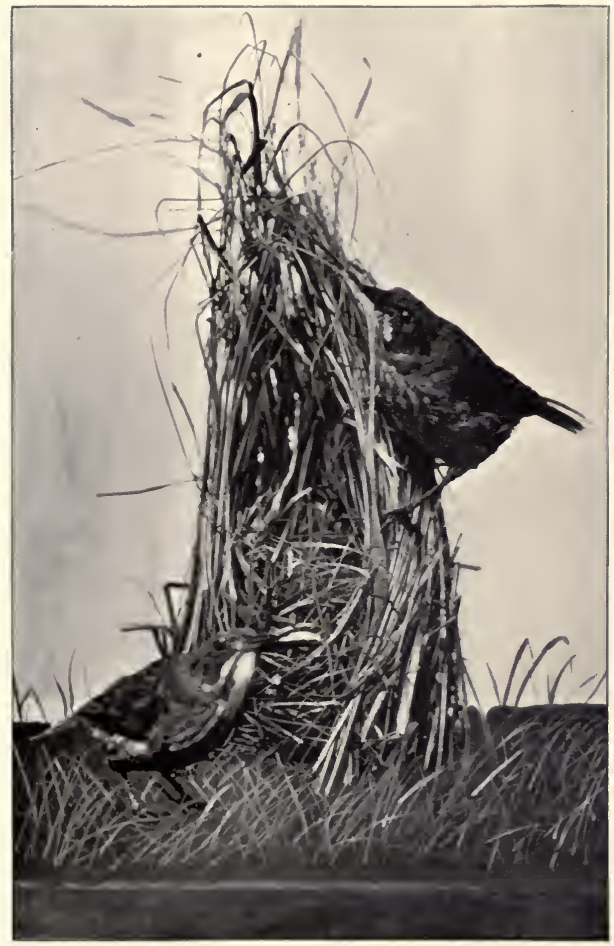

SEA-SIDE FINCHES AND NEST. 

wandered over a pretty high hill in North Carolina, and found many snow-birds about the bushes lining the rough mountain road. They appeared to be all singing, and made a ringing clatter that drowned other bird-voices deeper in the woods. Singling out separate birds, I heard two long-drawn and clearly-uttered notes that preceded the twitter, and if it had been in November and at my Jersey home, I should have translated it as "Snow's coming, 'tis, 'tis, 'tis." But here there was no sign of winter. The ground was pink with blooming arbutus, the air heavy with odor and the hum of bees. I was told these snow-birds remained all summer, and their singing meant "Spring's coming," and not the approach of a snowstorm. Occasionally, since then, I have heard in midwinter a song of this bird that was even of fuller volume.

In the Song-sparrow we have a resident species in the Middle States, but one that is migratory in the northern parts of the country; as, for instance, when "it arrives at St. John, New Brunswick, during the second week in April in immense flocks, and is usually accompanied by similar flocks of Robins and Juncos (snow-birds)." I would that we could speak of "immense flocks" of these birds here in the Middle States. Abundant, widely spread, and a feature of the whole year, and yet there was never enough of them. Unfortunately, too, the English sparrow has in a great measure driven them away from our town and the immediate surroundings of our country houses. I always associate the song-sparrow with a gooseberry-hedge, a dilapidated, lichen-coated paling, 
and a half-dead plum-tree; the last remnants of an old garden set apart for a few flowers and some beds of herbs in the closing years of the last century. Here the song-sparrows lived, and never seemed to wander away from it. In April, when the robins roused all sleepers at dawn, the sparrow was among the first to respond, and while yet the sun was below the horizon assured all the plain Quakers within hearing that he was a good Pres-pres-pres-pres-pres$b y$-té-rian. One needs the fresh eyes, quick ears, and supple limbs of youth to rightly study birds. Then I knew every song-sparrow on the farm, and there was a good deal of difference among them. Scarcely two sang quite alike, and yet there was that family resemblance that made the song unmistakable. In nesting, too, the birds differed, as many having nests in low bushes as others did upon the ground. The eggs varied so as to clutches, that in the common mind it was held that there were "bush chippies" and "ground chippies," for, curiously enough, all the small birds, except the humming-bird, whether warblers, flycatchers, or the small thrushes, were called by that one word "chippy." It was the extent of the average man's ornithological knowledge, beyond swallows and the game-birds.

Not very unlike the song-sparrow is another species that does not come even into our old-fashioned gardens, but lives in just such places as we are apt to keep clear of, as the swamps, marshes, and low riverbanks that are covered with bushes, and for this reason it is known, when known at all, as the Swampsparrow. They are not such sprightly musicians as 
the others, but have such good opinion of their own efforts that from April until October they enliven these waste places with

"a few trilling, rather monotonous minor notes, resembling, in some measure, the song of the Field-sparrow. . . . These notes are made with considerable effort, and sometimes with a spreading of the tail. In the spring, on their first arrival, this song is delivered with much spirit, and echoes through the marshes like the trill of the Canary."

Nuttall, from whom I have quoted, says these birds "thread their devious way with the same alacrity as the Rail, with whom they are indeed often associated in neighborhood. In consequence of this perpetual brushing through sedge and bushes, their feathers are frequently so worn that their tails appear almost like those of rats."

I have never noticed this, but the habit of wagging or dipping the tail, and, indeed, of teetering the whole body, as do the oven-birds, is very noticeable. Near a shad-fishery, about which I love to loaf in early spring, these birds are very abundant, and during the hauls of the seine, while waiting for the net to be drawn inshore, I have amused myself by the hour watching them hopping and running over the smooth beach, and often perching on a small projecting pebble. It was here that I learned of the bird's fondness for fish, and have often seen two or three tugging at a dead herring, trying to get from beneath the scales a good bite of the flesh. Fresh fish had, I judged, no attraction for them, but such as had lain in the sun for several days and were literally dry as a chip. Wilson states,-

"They form their nest in the ground, sometimes in a tussock of rank grass surrounded by water, and lay four eggs of a dirty white, 
spotted with rufous. So late as the fifteenth of August I have seen them feeding their young that were scarcely able to fly."

So far, so good; but he did not follow the bird up very closely, or he would have seen how very abundant they are in localities that suit them,-i.e., in the Middle States, - and that a considerable proportion do not migrate at all. When, as sometimes happens, we have no winter at all, these birds make their favorite haunts as lively in January as ever they do in June.

Another strictly migratory sparrow, and a very prince among the tribe, is the large, beautiful Foxie Finch. They come to the Middle States in October and generally pass on southward, but occasionally some remain. I know that in mild winters this is true. At such times the little flocks are skulkers, and have to be started up by throwing a stick into the thicket, when they rise with quite a whirring of the wings and twitter musically. Their single cheep has a bell-like ring that fits well with the bright, crisp air of a frosty October morning, and when a dozen sound this note together the effect is very pleasing. Their favorite haunts in autumn, and, indeed, also in spring, are the old weed-tangled worm-fences, with here and there a tree towering above it. The trees do not figure in their history in October, but in March, when they are northward bound for their far Canadian homes, they are in an anticipatory frame of mind, and often going well up towards the tops of the trees, they sing an exultant song that is positively charming. William Brewster admirably describes it as a 
"fervent, sensuous, and withal perfectly-rounded carol. . . . It expresses careless joy and exultant masculine vigor rather than the finer shades of sentiment."

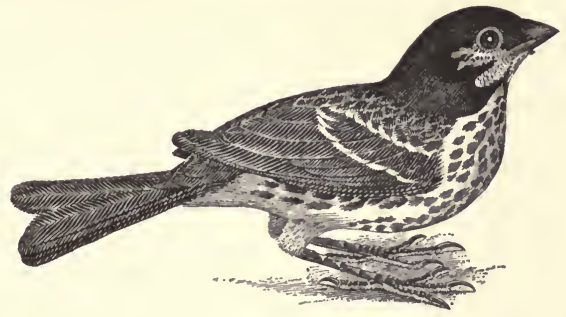

Foxie Finch.

On the Pacific coast, in the mountains of California, and in the Rocky Mountains there are foxie sparrows that are "varieties" of our Eastern form, much like him in a general way, but with no characteristic that is an advance over the bird that has ever been a delight to all who are fortunate enough to know him.

When, forty years ago, it was my good fortune to be allowed to go with "the boy" after the cows, about sunset, as I passed along a narrow path that extended for several rods through a briery tangle, I never failed to see a strange black, white, and brown bird that seemed to follow us and resent our intrusion by the vehement utterance of what sounded like re-treat, re-tréat. I was told then that the bird was the Swamp-robin, and later fell to calling it "Chewink." As with many another bird that gets its familiar name from the fancied resemblance of its 
song to words in our language, this one has received several, and as all are objectionable, or for some other reason, they are spoken of now in genteel society as Pipilos. To me they are Chewinks, and ever will be.

In April or earlier they make their appearance and stay until November; but, as in many other cases, quite a number remain during the winter in their summer haunts. Their requirements are wet ground, weeds, and dense underbrush. If among this are many tall trees, so much the better. In other words, they love a swampy woods better than a dry one. The chewink is not restricted to a simple calling out of his own name. In May the male birds attempt an elaborate song, and if not wholly successful, it is by no means a complete failure. The efforts of various writers to express it in syllables are not quite satisfactory; at least, they use too many consonants and not enough vowels. The love-song of this bird sounds to me like $\overline{\mathrm{ee}}-\overline{\mathrm{oo}}$, еуее е. It is soft, liquid, and without trace of consonantal harshness, and being continued with slight variations, is free from monotony. This song is only uttered, I think, when the bird is perched some ten or twelve feet from the ground.

The nest is placed directly upon the ground, is made of dead leaves and grass, and the eggs are as inconspicuous as dirt color can make them. It is not easy to find them, but very easy to step where you should not have put your foot and so destroy them. Whether this happens or not, your presence is a matter of great distress to the birds, and if you have 
proper regard for another's feelings you will retire. There is not a vestige of reason, at this late day, why any one should rob a bird's nest.

In the summer of 1893 I had a curious experience with a male chewink. I was on a legitimate errand in a tangled swamp, when suddenly a chewink appeared directly above me, scolding vehemently. I went about my business, and having gathered the plants that I was after, walked a full eighth of a mile to a grassy bank among old oaks to take a deliberate, long-drawn-out nooning. The bird followed me, and when I laid down and attempted to take a nap, came very closely and chirped che-wink into my ears so that sleep was impossible. I remained in the one spot from I P.M. to 2.30 P.M., and then started for home, the bird still there, but showing no disposition to still remain in my company. I never knew what was the trouble, but think it probable I had stepped upon its nest while botanizing in the swamp.

I have often wondered if any one was so indifferent to birds that he would not turn his head if a Cardinal Grosbeak flashed by. I would rather see than know such a man. All my life I have known the Winter Red-birds, for by this name in my early days they were always spoken of to distinguish them from the Summer Red-bird, or Tanager; and in Central New Jersey, too, the name of Winter Red-bird was a most appropriate one, for the bird was a common, persistent feature of the December landscape. I never could understand why it was that Wilson should assert of them that 
"They are in song from March to September, beginning at the first appearance of dawn, and repeating a favorite stanza, or passage, twenty or thirty times successively; sometimes with little intermission for a whole morning together; which, like a good story too often repeated, becomes at length tiresome and insipid. But the sprightly figure and gaudy plumage of the Red-bird, his vivacity, strength of voice, and actual variety of note, and the little expense with which he is kept, will always make him a favorite."

They are every whit as much in song the other months. They are, as a matter of fact, never out of it. Mute, indeed! I have seen many a score of them, singly, of course, when the ground was completely covered with snow, perched upon a low shrub, whistling so clearly and loudly that they could be heard in the house with the windows closed. A bright sunny morning after a snow-storm seemed always to be a favorite time with them, and the whole range of their songs would be performed at a single sitting. As a winter bird they are a superb success.

From April to October they lead a commonplace life,-a well-behaved sparrow and nothing more. Of course their bright plumage makes them conspicuous, and they are themselves aware of this, for they are ever on the alert and flit out of sight at the slightest hint of danger. Of course a thick tangle of greenbrier is a great protection, and I have often wondered why they did not nest in them instead of in more exposed places, for I have found many nests that were of easy access.

A condition not common to the sparrows obtains among the Cardinals, that of the females being excellent singers and much given to exercising their powers. But they are not the equals of their lords 


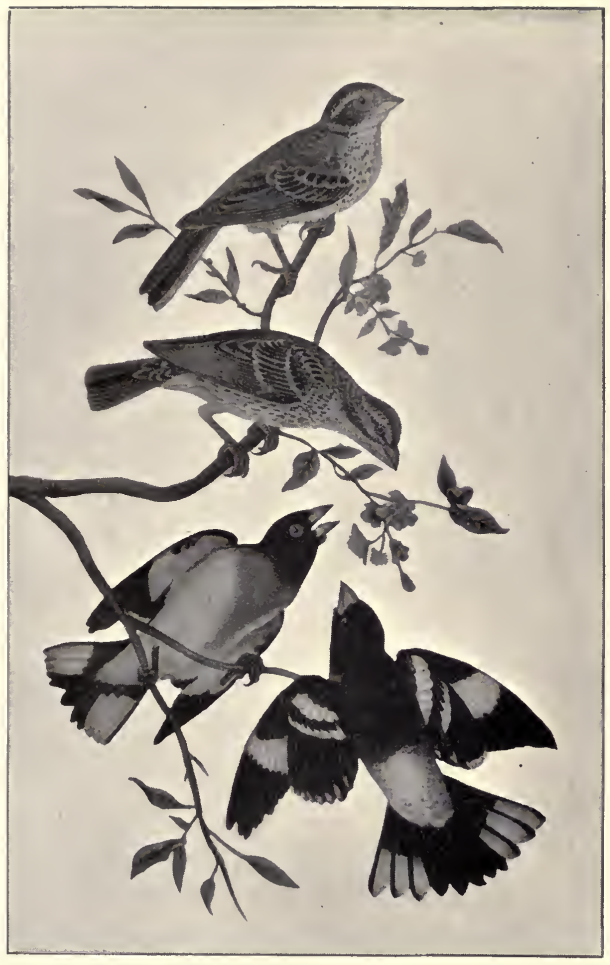

ROSE-BREASTED GROSBEAKS. 

and masters, and, as in mankind, they should not be. Occasionally these birds, both male and female, take to imitation, and where the note mimicked is a clear, full one, the success is pronounced. I remember hearing a whippoorwill imitated, and as it was in broad daylight, the sound was the more noticeable; for, contrary as birds are disposed to be, I never heard the whippoorwill at high noon.

Nuttall has treated of the Cardinal's song most exhaustively and correctly, but so very varied are the many whistlings that the bird must be heard to be appreciated. Nuttall gives a dozen variations of the bird's song. It were easy to ditional ones. We get an ever, by remembering one tones of the Cardinal are in the manner of the Cardinal Grosbeak.

A migratory grosbeak, brilliantly black and white, with a superbly rose-tinted breast, comes from the south to the Middle States every spring, and while many remain, others go farther north, even to Canada, although beyond the United States they are said to be rare. We all have our preferences and are entitled to them, and my fancy is that this Rose-breasted Grosbeak is our finest singer. Of course there goes up the shout, "What of our thrushes?" That has 
nothing to do with it. I am speaking for myself only. It has always been a matter of surprise to me that those who have had the best opportunities of studying this bird have spoken of it in such an unenthusiastic way, even actually comparing it to the tiresome cacophony of the commonplace robin.

I have never seen any description of the song that seemed to do it justice, although Nuttall's is an approach to it, when he says it is "with all the varied and touching tones of the Nightingale." And adds, "while thus earnestly engaged it seems to mount on tiptoe in an ecstasy of enthusiasm and delight at the unrivalled harmony of its own voice. The notes are wholly warbled; now loud, clear, and vaulting with a querulous air, then perhaps sprightly, and finally lower, tender, and pathetic."

In the West is found the Black-headed Grosbeak, of which Dr. Coues says,-

"Like others of the same beautiful genus, it is a brilliant and enthusiastic vocalist, its song resembling that of the Rose-breasted Grosbeak, and having much similarity to that of the Baltimore Oriole."

Its habits generally are the same as those of the Eastern bird.

The Blue Grosbeak belongs to the "more southern eastern United States," and comes north " regularly (but very locally) to Pennsylvania, Kentucky, Kansas, etc."

There is no possibility of confusion or doubt as to the distribution in summer of the Indigo-bird. It is too abundant for that, and cannot be mistaken for any other species. 
"Its favorite haunts while with us," remarks Wilson, "are about gardens, fields of deep clover, the borders of woods, and roadsides, where it is frequently seen perched on the fences. In its manners it is extremely active and neat, and a vigorous and pretty good songster. It mounts to the highest tops of a large tree, and chants for half an hour at a time. Its song is not one continued strain, but a repetition of short notes, commencing loud and rapid, and falling by almost imperceptible gradations for six or eight seconds, till they seem hardly articulate, as if the little minstrel were quite exhausted; and after a pause of half a minute or less, commences again as before. Some of our birds sing only in spring, and then chiefly in the morning, being comparatively mute during the heat of noon; but the Indigo-bird chants with as much animation under the meridian sun in the month of July as in the month of May, and continues his song, occasionally, to the middle or end of August."

In the South and West are found the Varied, Lazuli, Beautiful, and Painted Buntings, all belonging to the genus Passerina, of which our Indigo-bird is the Northern representative. They are all more beautiful birds than the one we have treated of, but in general habits much the same, the song even having a strong family resemblance, and no one much the superior of the others. Occasionally a "straggler" Painted Bunting has been reported as found "wild" in Pennsylvania. One of these, I am positive, was an escaped cage-bird.

The Black-throated Bunting, or " Dickcissal," ends the sparrow series, but because last is by no means least. In 1873 I spent several months in a house in Central New Jersey beside which was an open lot. There was some grass and more weeds growing in it. For convenience, I adopted the lazy man's plan of making a short cut across this open space, and before I had worn much of a path I found that the 
lot was literally full of birds. They came one morning or in the night, about May I, and remained until late in October. They were almost as noisy as the street sparrows, but a good deal more musical. They were black-throated buntings. My attempt made at the time to imitate their song resulted in se-tsee-sit$\ddot{a}-s \overline{e e}-s \overline{e e}$. As this differs somewhat from Nuttall's and Wilson's account, I will add that I think I never failed to hear two or three singing at once, and so may have added notes of one bird to the song of another. This weedy, open lot, on the edge of the town, seemed to be wholly to their liking, and they did not stray from it. There was water at the lower end and grasshoppers innumerable, so the birds remained eating, drinking, and making merry until autumn was well advanced.

I found several nests, all upon the ground, but none with eggs. They all contained young birds, and how they escaped the long procession of prowling tomcats that made night hideous and marred many a day is one of Nature's unsolved problems.

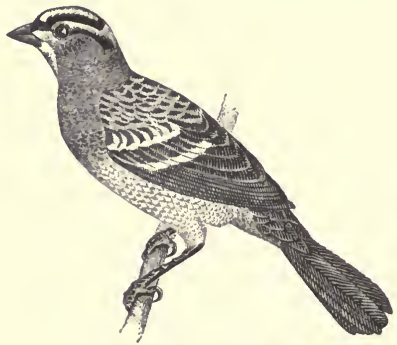

White-crowned Sparrow. 


\section{CHAPTER IV.}

THE PERCHING BIRDS.-(Concluded.)

$\mathrm{HE}$ first of the several groups to be considered
in this chapter is that important one, the Tyrant Flycatchers. The very name suggests a lively time, and I certainly never saw a lazy bird among them. They are fly-catchers, not fly-hunters, and it is the insect on the wing that concerns them more than the crawling slug down in the dirt. These birds are divided by ornithologists into eleven genera, and, of course, there are many species, but I think that the general family likeness is so pronounced that no one will be likely to confound them with birds of other families. Some of them are beautifully colored, but in the United States the great majority have neither color nor voice to commend them. They are practical birds, eminently useful rather than ornamental.

The most beautiful of these birds are two species that are distinguished by their long forked tails and light, gray-white, pink, and yellow coloration. The Fork-tailed Flycatcher is said to be "accidental" to Mississippi, Kentucky, and New Jersey, and the Scissor-tailed is a real resident of our territory, keeping closely to the Southwest, but occasionally going so far from home as British America.

Of Kingbirds proper there are five species, and they do not differ much among themselves. Every 
boy in the country knows the Kingbird. No one has probably missed the sight of a little dark-gray bird with a bit of a topknot and white edging to his tail launch out and upward, and when above some passing crow dip down and nip, or make believe to nip it, about the head.

In May or June, when the kingbirds have their nests, there are so many other and more attractive birds that we do not notice them so much, but they play a prominent part in August and September, when young and old gather in loose companies, often associated with birds of other kinds, and long before cold weather has set in proceed on their southward journey.

Another flycatcher, and one that we are sure to hear before we see, is the Great-crested. It is very plainly dressed, and of all our birds has the most disagreeable voice, a veritable grating squawk that must be uttered of necessity rather than choice, for the bird can surely only be pained when it hears itself speak. They reach the Middle States in April and make as long a stay as the kingbird. As flycatchers they are much the same, and are just as brave so far as defending their nests is concerned, but do not seem to be anxious to forever have a quarrel on hand.

Unlike the kingbird, which builds an open nest, the great-crested wants a commodious hollow in a tree, and will not hesitate to question the rights of the little red owl, although the latter has had undisturbed possession all the previous winter. As Wilson states,- 


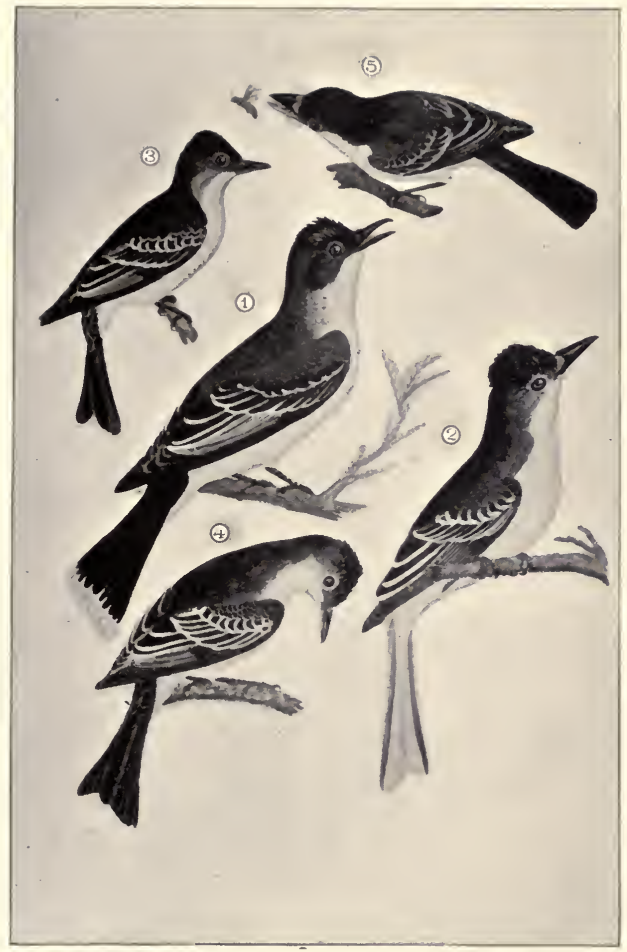

1, KING-BIRD. 2, GREAT-CRESTED FLYCATCHER. 3, WOODPEWEe. 4, PHFBE-BIRD. 5, SMALL GREEN CREST. 

" $\mathrm{He}$ builds his nest in a hollow tree deserted by the Bluebird or Woodpecker. The materials of which this is formed are scanty and rather novel. One of these nests, now before me, is formed of a little loose hay, feathers of the Guinea-fowl, hog's bristles, pieces of cast snake-skins, and dog's hair. Snake-skins with this bird appear to be an indispensable article, for I have never yet found one of his nests without this material forming a part of it. Whether he surrounds his nest with this by way of terrorem, to prevent other birds or animals from entering, or whether it be that he finds its silky softness suitable for his young is uncertain; the fact, however, is notorious. The female lays four eggs of a dull cream color thickly scratched with purple lines of various tints, as if done with a pen."

An almost domesticated species is the familiar Pewee, or Phœbe as it is often called. In some localities the name Bridge Pewee is heard, this name being derived from the locality chosen for the nest. But these birds build much nearer dwellings than that, and often on the pillars of porches where people are continually going and coming. Indeed, when a spot is once chosen by them they are not at all disposed to give it up, and when the locality meets with no opposition, if the first occupancy is successful, the birds will continue to occupy it year after year. It is the same pair of birds, too, as has been proved by experiment, and we have in pewees certainly a very prominent instance of migratory birds that are permanently màted.

The pewee is the earliest of our flycatchers to arrive. I have seen it as early as the end of February, and to find them lingering during our November Indian-summer days is not unusual.

This bird is represented along the Pacific coast by a black phœbe, and there is also another, not so darkly colored, known as Say's Flycatcher. Their 
habits are not materially different. Dr. Coues says of the latter, "It is a bird of open country, the Flycatcher of the plains. ... It has the same vibrating motion of the tail so characteristic of the Eastern pewee."

In New England and "higher mountain districts of the United States" is found the Olive-sided Flycatcher, which does not with any show of regularity visit the lowland tracts of the Middle States, although they have been found in the neighborhood of Philadelphia. As a Colorado bird, it is described as keeping to "the tops of the trees, and is an active flycatcher; its voice is loud and distinct, and its nest is placed in the top of a pine and zealously guarded from all intrusion with as much fierceness and energy as the kingbird's."

The Wood Pewee is almost as common as the phœbe bird, but it has not yet become so familiar as to nest otherwheres than in trees, and among them it passes the whole summer away. It comes to the Middle States in April and disappears some time before the common pewees have departed. While not a shy bird as I have seen it, it prefers shade to sunshine and tall trees to scrubby ones. It loves an orchard, but it must be one of the old-fashioned kind, with enough of general neglect about it to attract insects of all kinds. Then, too, the trees must be large and have in their branches a good range of hunting ground. I have often been amused at the diving for insects practised by these birds. Perched on a dead twig of some tall tree projecting into open space, the wood pewee will look down for insects 
that may pass beneath, and sighting one, it glides gracefully downward, seizes the insect, and then returns to its perch with a graceful upward curve that shows how beautiful a movement flight may be. And again, it will often launch leisurely into space, and with outspread wings and upward toss of the head sing as lazily as it is possible to utter the syllables $p \vec{e} \vec{e}-w \vec{e} \vec{e}$. The words, if we may call them such, are the same, but they have none of the snap of the phœbe.

Wood pewees are found in the West and South and in British Columbia, migratory like the Eastern bird, and much the same in all respects.

The Yellow-bellied Flycatcher is rare in the Middle States, not common in New England, and found nesting in Canada. It is migratory. It has "gone against the rules" more than once and stayed all summer in New Jersey, even nesting there; and Warren, in "Birds of Pennsylvania," gives various parts of that State as its summer home. The song is rather pleasing and more elaborate, as I have heard it, than it is described by Nuttall even. The nest that I have seen was in a tangle of Virginia creeper that clung to a small tree, and was fully twenty feet from the ground.

When the April sunshine has caused the leaf-buds to open, and as we look through the woods we see a pale-green shimmer, and sunlight penetrating to where in a few weeks it will be effectually shut out,at such a time and in such a place you will see a small greenish-gray flycatcher,-the Acadian,-now sailing from tree to tree, now pitching down from higher to lower perches, and again mounting up. 
ward. All the while, besides the snapping of the beak with a little click, you can hear a faint peeping sound, as if the bird was fretful, and at stated and not long intervals the bisyllabic refrain that is much the same in all the species. After listening to them for many years, I believe that tshee-kee as nearly as may be describes their notes, the greater stress being laid on the first syllable. This bird is common in New Jersey, in woodland tracts, and will come into villages where there are abundant shade trees and in old church-yards.

In Central New Jersey they build in trees at a few feet only from the ground, and secure the nest to two or more limbs that are growing in the same direction. Southward the bird is more abundant, and its place in New England is taken by the Least Flycatcher or "Chebec," a name derived from the song or utterance of this species. This species breeds abundantly in most parts of New England. Dr. Coues says, "It is not ordinarily found in gloomy woods like $E$. acadicus, nor even in heavy timber of any kind." The bird's nesting habits are much the same as those of the preceding.

Another of these little fellows is Traill's, which is a migrant, going into New England to breed, and of course away beyond, northward. The bird has some minor peculiarities that have to be closely studied to distinguish it, when alive, from the others. Thus, Mr. Maynard, a very close observer, calls attention to the se-witk of the least flycatcher being more rapidly uttered and in a lower tone than the ke-wink of the Traill's. 
I am very sure that Traill's flycatcher does occasionally linger in New Jersey, and the other, the least flycatcher, is not uncommon. There are no birds that give to our quiet woods a greater charm than these little flycatchers. The right royal songsters generally seek the edges of woodland, or content themselves with thickets, the river's banks, or even the open field. The high, dry, open woods are so apt to be deserted in summer that we have a feeling of loneliness when in them; but if, happily, an Acadian flycatcher wanders your way, you have excellent company. He offers no music and performs no acrobatic feats; is neither philosopher nor fool ; but what we all enjoy more than either, a right royal good fellow.

Following in the order given by Ridgway, but a wonderfully different bird, is the beautiful Horned Lark. We have been considering birds of the trees and of the air, and are now brought to the ground, for these larks are either on the grassy fields or in the air, going from one field to another. Unless, therefore, seen in flight, it is quite possible to pass them by, for they not only are not shy, but if busy feeding prefer to squat rather than expose themselves by taking wing.

The horned lark of the Atlantic seaboard is the lark, and the eleven varieties scattered in the West are only varieties, with a little more or less tone in the color of the feathers to give joy to museum students and confuse those who like the live bird in the home of its own choice. Our horned larks, then, spend their summers in Newfoundland and Labrador, 
and come down to civilized regions in November and stay until March. They come in companies and remain thus associated. In their travels they sometimes hit upon spots quite to their fancy and show no disposition to leave them. A flock of considerable size was seen December II, I893, in a field on Burlington Island in the Delaware River, and at this time, March 15, I894, they are still there. If the food supply is sufficient, there appears to be no disposition to continue on the move.

\section{Wilson says,-}

"This is the most beautiful of its genus, at least in this part of the world. It is one of our winter birds of passage, arriving from the north in the fall, usually staying with us the whole winter, frequenting sandy plains and open downs, and is numerous in the Southern States, as far as Georgia, during that season. They fly high in loose, scattered flocks, and at these times have a single cry, almost exactly like the Skylark of Britain. They are very numerous in many tracts of New Jersey, and are frequently brought to Philadelphia market. They are then generally very fat, and are considered excellent eating. Their food seems principally to consist of small, round, compressed black seeds, buckwheat, oats, etc., with a large proportion of gravel. On the flat commons within the boundaries of the city of Philadelphia flocks of them are regularly seen during the whole winter. In the stomach of these $I$ have found, in numerous instances, quantities of the eggs or larvæ of certain insects mixed with a kind of slimy earth. About the middle of March they generally disappear on their route to the north. Forster informs us that they visit the environs of Albany Fort in the beginning of May, but go farther north to breed; that they feed on grass seeds and buds of the sprig birch, and run into small holes, keeping close to the ground, from whence the natives call them chi-chup-pi-sue."

The Western forms are not reported to materially differ in their habits. According to Warren ("Birds 
of Pennsylvania"), one of these varieties is a summer resident about Lake Erie.

We have two species of Magpie in this country, but none of the more Eastern form ever venture along our Atlantic coast.

$\mathrm{J} . \mathrm{K}$. Lord, in his delightful volumes on British Columbia, has the following gruesome account of magpies:

"These thievish murderers are everywhere from Vancouver Island to the Rocky Mountains. . . I I call them murderers, because I have seen them kill mules; and, worse than that, pick the eyes out of a living animal when, wounded and helpless, it lay down to die ; and pounce upon maimed birds, break in their skulls, and deliberately devour their brains whilst the muscles still quivered with life."

This picture is so bad that the regions where magpies are not can consider themselves fortunate.

Of Jays we have nine species, and of course many local varieties. They appear from the accounts of various writers to be very much alike, and the jay nature no more than magpie depravity is to be commended. Dr. Coues, in his delightful volume entitled "Birds of the Northwest," has shown how widespread is our antipathy to the Cat-bird; my own experience leads me to think this ill feeling is more generally shown against the Blue Jay, the one species common to the Middle States. Of course the bird has some good traits, and I am always glad to hear his hearty call through the autumn woods; and the occasional sweet flute-like note he utters is one of the richest of our bird notes,- - a whole bird concert squeezed into a single note that comes rolling down the narrow pathway through the woods. 
The blue jay is a resident bird, and a thoroughly bad one as we see bird-life; but in truth what the jay does openly many a "dear innocent" does behind your back. There is a smack of original sin in every bird that flies. I have seen a dove with redhot temper. But the jay goes for very little himself, and when he eats a nestful of If song-thrushes and murders rose-breasted 1 grosbeaks, I am ready to wage a war of extermination.

But when win-
ter comes and the
world is snowsaucy jays sporting in the bare trees are truly welcome.

The blue jay builds a large nest of coarse sticks, and seems to care little about its being conspicuous, and is ready to defend it, as I can testify. I undertook to remove a young bird nearly ready to fly, when I was attacked by both the old birds and struck not only by their wings, but pecked. My hat protected my face, but one hand received a blow on the back that broke the skin. For days I had watched this pair of jays to see if young birds from other nests were brought as food for their own young. I could not determine that this was the case, and was glad to find that they did bring a good many grasshoppers. My field-glass enabled me to be positive of this.

The Canada Jay, Whiskey Jack, or Moose-bird, is more like the magpie in its habits and has none of 
the blue jay's beauty. Those who have seen much of this bird in its northern home find a great deal to tell about it, but the reports are not such as to excite much interest.

Steller's Jay is a prominent Western species, with habits not unlike those of its Eastern cousin. Dr. Coues says of it, "It is difficult to describe the notes of this jay, he is such a garrulous creature and has such a variety of outcries." And again he remarks, "it will eat anything eatable."

\section{J. K. Lord says of it,-}

"Steller's Jay makes its presence known by the continual utlerance of a discordant scream; hopping perpetually from bough to bough, then darting down to nip an insect, performing short, erratic flights, and jerking its crest of bright feathers up and down, its noisy song seems everywhere. The Blue Jay appears the embodiment of restlessness, and by sheer impudence attracts attention from even the lone hunter. Fond of frequenting the haunts of man, jays are always plentiful near Indian lodges or white men's shanties. By no means epicurean in tastes, they readily devour anything,-seeds, salmon, grasshoppers, or venison. The nest, artfully concealed amidst the thick foliage of a young pine-tree, is composed of moss, small twigs, lichen, and fir-fronds, and lined with deer hair."

The habits of all these jays differ in one respect from those of the common jay of the Middle States, for the latter show no fancy for human habitations. Extreme weather may tempt them to a corn-crib, and they will steal very cautiously to where pigs have been slaughtered, but the familiarity so marked in other species I have never known to be exhibited by the blue jay of the Atlantic seaboard States.

The Raven, that has figured for many centuries in literature and folk-lore, and is looked upon with sus- 
picion by all people other than naturalists, is an abundant bird in the West, and quite rare in the Atlantic seaboard States, except in scattered localities immediately on the coast and among the mountains.

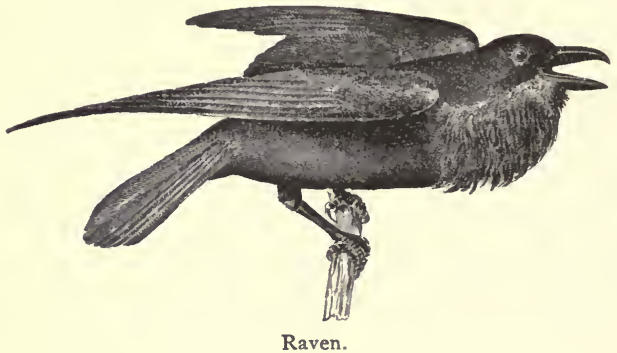

Some years ago a family of seven ravens had their home in a magnificent cedar and holly forest on the Jersey coast. Wandering aimlessly about,-it was in June,-I came upon them suddenly, and their strange cries were thoroughly weird and unbirdlike. I thought then how readily they might be considered as words of any spoken language; and later, that same day, as I was watching the storm-clouds gathering over the ocean, from out them came these same ravens, calling aloud as they approached and uttering cries as they passed over my head and made for their home in the woods. It is not strange that superstition has invested them with wickedness, and laid at their door the blame for many a misfortune.

The Western White-necked Raven does not differ essentially in its habits. 
It would seem entirely unnecessary to refer to the Crow. Everybody knows the bird at sight and supposes he knows the details of its mind, body, and estate, but here "everybody" is mistaken. The ornithologist knows this bird, but the public do not. All that can be said against it is rolled like a sweet morsel under the tongue, but who has spoken in its favor? The Farmers' Clubs throughout the land and State Legislatures and like learned bodies may declaim and enact as they see fit, but the truth remains the truth. The crow is a useful bird in spite of the mischief of which it is guilty, and that is the sum and substance of the whole matter; but if short-sighted farmers will persist in persecuting these birds, and probably they will to the end of time, it is to be hoped that they will learn to discriminate between them and the Fishcrow, which is as absolutely harmless as a swallow. They are a Southern species, but come every March into the Delaware Valley and remain until September. The impression that they come and go with the shad and herring is altogether a mistake. Wilson, who first made known this species to naturalists, gives an account of their gull-like habits as he saw them in the South; but here in the Delaware Valley they are more crow-like and very seldom snatch floating food from the surface of the water. They are not shy, and after the hauling of the seine will come very near to the fish-cabin and pick up such refuse as it finds. The voice of this crow is quite different from that of the common bird and yet not easily described. The two must be compared and then they will be readily recognized. The bird itself 
is smaller, measuring about sixteen inches, while the common crow measures eighteen to twenty inches; but besides this, the general build of the fish-crow is more slender, and the wing-movement varies to a more gull-like manner, which is a peculiarity that we readily detect when familiar with the bird.

Florida, California, and the Northwest each have a crow of their own, but they do not vary in appearance or habits greatly from the typical form of the East. In every country they are cunning birds, and it is probable that no other form of bird-life has advanced so far as have these crows "intellectually."

In the " higher coniferous forests of Western North America, north to Putnam River, Alaska, south to Arizona, east to (and including) Rocky Mountains," is found a "crow" known as Clarke's Nut-cracker.

Dr. Coues says of it,-

"It rarely descends below an altitude of 3000 feet, and has been observed on peaks 10,000 feet high. A hardy bird, finding its food at all seasons, Clarke's Crow is not a true migrant; that is to say, it does not move north and south at regular periods; . . . is an indiscriminate feeder upon vegetable substances, giving preference, however, to the seeds of the pine, berries of the cedar, and acorns."

The Bobolink, Reed-bird, Rice-bird, Ortolan, and I know not what else, is a bird that is thoroughly well known. Popular literature seems better fitted to teach ornithology than the best efforts of scientific naturalists. "Bobolink" has become a household word, and the bird has been pictured until every child carries it in his "reader" or knows it from the dainty pages of juvenile books, now, happily, a feature of every home. Bryant has made "bobolink" classic, 
and Thoreau has fixed the bird's song securely in our lasting literature, saying of these birds as he heard them near Concord, "and the meadow is all bespattered with melody." Their history is a short story: they winter in the south, and coming north in spring, scatter over the country, nesting for the most part in New England and beyond; but a good many hang back when they reach the Middle States and are here all summer. Then the males are black and white, or appear so, and are full of song. Certainly of a bright May morning it is worth a long walk to hear them. This song as summer wanes dwindles to a mere "chink," but this is clear, metallic, and when uttered while the bird is flying high overhead can be heard for a long distance. By the close of summer, too, there is another change, and the bright black-and-white suit is changed to a yellow-brown one; and now the birds southward bound are bobolinks no longer, but reed-birds until they reach the Carolinas, and then they are rice-birds. The poetry is all gone when the birds come back in August: they have left their music behind them, and are now so prosy that the melody of May mornings is forgotten and we are ready to eat the little fellows. It is hard to imagine any one cruel enough to harm a bobolink in May, but it is more difficult to imagine any one capable of resisting in September a reed-bird upon toast.

The Cow-bird, which is perhaps best known as Sheep Blackbird and sometimes as Cow-bunting, is a curious creature. The male bird is bronzed and dark blue, and has some animation when it bubbles over 
with its few peculiarly liquid notes. The female is a nonentity in appearance, and would be in fact, were it not that it is too lazy, too ignorant, or too awkward to build itself a nest and look after it, but having an egg to dispose of, drops it in the nest of some other bird and thinks no more about it. It puts one a little out of patience with evolution that any victim of the cow-bird should be willing to accept the situation, and not only hatch but rear the foundling. A single year's protest would annihilate the species, and they would never be missed. This is a little hard on them, perhaps, but, seen at any time and under any circumstances, they can hardly be considered as interesting, unless it is in autumn when they congregate in quite large flocks, and if the day be windy they seem to be blown about like a windrow of dead leaves. They are migratory after a fashion, coming in March and sometimes quite early in the month, and are often in the low meadows along the Delaware River as late as the middle of November. Indeed, Indian summer seems to be a favorite time with them, and they have an amount of animation then that seems unnatural, a sort of intoxication.

In the Southwest this bird is replaced by the "Bronzed Cow-bird," which seems a strange distinction, as our Eastern bird, in spring at least, is about as "bronzy" as it well can be.

In Western North America, in marshes, east, regularly to Wisconsin, Illinois, Kansas, and Texas, we have the Yellow-headed Blackbird. It is "accidental" in Pennsylvania, and even gets as far away from home as Massachusetts. 


\section{Bonaparte states, -}

"The Yellow-headed Troopials assemble in dense flocks, which, in all their varied movements and evolutions, present appearances similar to those of the Red-winged, which have been so well described by Wilson. They are much on the ground like the Cow Troopial (Cow-bunting of Wilson); on dissection, their stomachs have been found filled with fragments of small insects, which seem to constitute their chief food, though doubtless they also feed on vegetable substances. Their notes resemble those of the Red-winged Troopial, but are more musical. The range of the Yellow-headed Troopial is very extensive, as it is found from Cayenne to the river Missouri; although it passes far north in the western region, yet it does not visit the settled parts of the United States."

The Red-winged Blackbird is almost as well known as the crow. Whether in early spring it is the pair that have their nest in the wet meadow and the male singing con-que-rēe from dawn till dark, or it is some huge flock in autumn that literally, for an instant, blots out the sun, it is the same familiar blackbird that fills a place in every country landscape. Like the crow, it would be sadly missed if exterminated, not only for the pleasure it affords, but because of the great good it accomplishes. I am speaking now of the Middle States. It is a veritable pest in the South when in "clouds" it settles upon the rice-fields, in this respect equalling the destructiveness of the reedbirds; but here in the Delaware Valley the conditions are all different. The red-wings are seen even in winter in scattered flocks of a few individuals. In March these flocks grow larger and there are many more of them. Then the day of breaking flock and mating comes, and with it comes the scattering of sweet song all over the country. Certainly there is music in the blackbird at this time. 
"Why chidest thou the tardy spring?

The hardy bunting does not chide;

The blackbirds make the maples ring

With social cheer and jubilee;

The red-wing flutes his $o-k a$-lee,"

and, fluting it, blots out all the disaster that winter has wrought. There is no early spring-tide note so full of summer; none that warms the landscape so much and tempers the March winds till they are softened to a zephyr. Few suspect the magic of a wild bird's note, but finding it, the world is tinted in more glowing colors.

There is a brief interim in summer when the redwings are but seldom seen. Not that they really leave us, but young and old wander off, and I never traced their wanderings; but in September they are all back, and now, congregated in great flocks, they resort to the long reaches of marshy meadows along the river. Here I have seen them literally by the thousands; and when they are joined, as sometimes happens, by flocks of rusty grakles from the north and the crowblackbirds of the neighborhood, there is a tumult of voices that cannot be described. I have seen an acre of marsh black with birds; so black that the vegetation could only be seen as mere narrow ribbons of light brown. This does not last long, for the purpose of flocking is to migrate, and before the weather becomes cold or very stormy the greater number of these huge flocks have passed southward, but not all. I never knew a winter too cold for them, and about open water, in meadows with bottom springs, and sheltered reedy nooks in woodland tracts a few are 


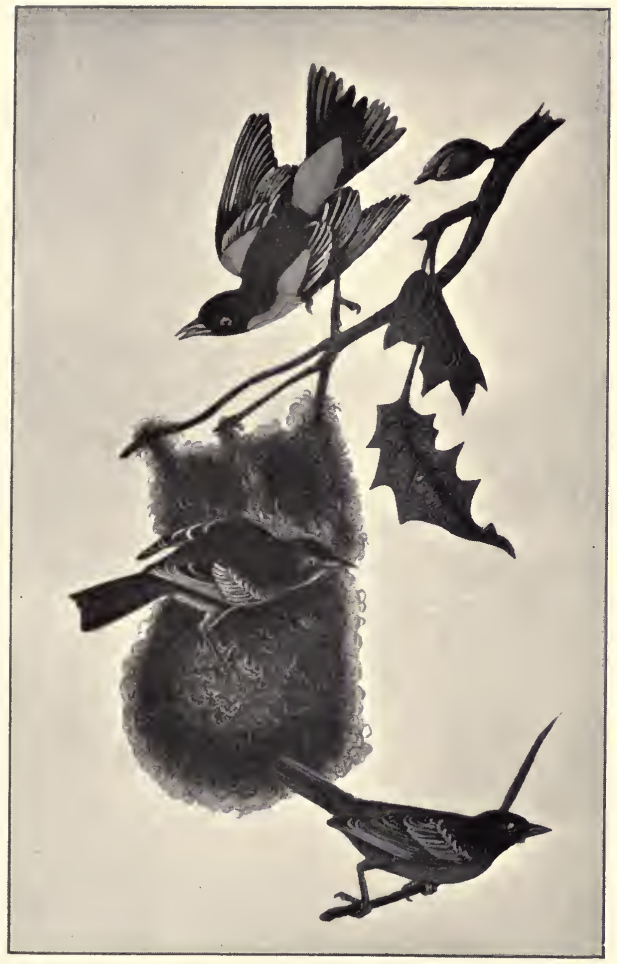

BALTIMORE ORIOLE. 

sure to be found; and when there are warm, sunny days, though it is midwinter, they seek out their spring-tide haunts and the males sing as merrily as in April.

The Western varieties are pretty much the same. Dr. Coues mentions the "Tricolors flocking in vast numbers." These appear to be a much tamer bird than our Eastern form, as he speaks of them as thronging the streets of a town, which is not a habit of our bird, for I never yet saw a Jersey village so small and so sleepy that red-wings would venture into its single street to forage. In this they are unlike the grakles, (to be considered), for they will come into large towns and even nest in trees a little off much-travelled streets.

At first glance it would not appear that red-winged blackbirds and meadow-larks had anything in common, and yet they are really much alike in some respects; so much so that at one time of the year they are closely associated. They breed in the same meadows, but build very different nests; the blackbird's being in tufts of coarse grass or tangled vines off the ground, while the meadow-lark builds on or in the ground, depending upon the long grass to conceal it; but while there are eggs or young to look after the two birds are much together and sing constantly, the lark usually climbing to the top of a tree rather than contenting itself with a fence-post, and there whistling clearly "I see you-you can't see ine," and it takes sharp eyes to make him out, as the bird seems to study a position that makes him one with the leaves. 


\section{Wilson says, -}

"Though this well-known species cannot boast of the powers of song which distinguish that "harbinger of day," the Skylark of Europe, yet in richness of plumage as well as in sweetness of voice (as far as his few notes extend) he stands eminently its superior."

Of course it must be remembered that the meadow"lark" is not a lark at all, but allied to the red-wings and reed-bird on the one hand and orioles on the other. It does not seem to me that Nuttall does our bird justice in the matter of its song.

The Western Meadow-lark, which is now considered but a variety, has a much sweeter and more varied song, and those who have heard it are inclined to believe that it is a difference having true specific

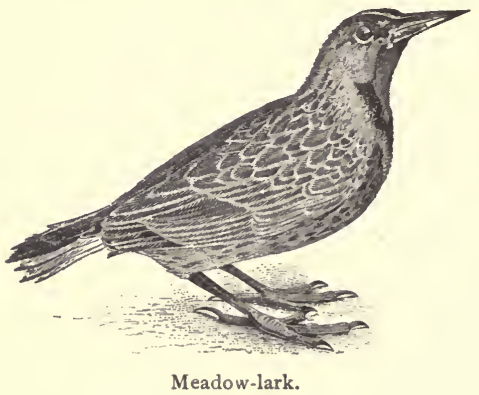

significance. On the other hand, it must be remembered that the difference among birds in the same flock in the Middle States is very marked, and occasionally, when we have a peculiarly bright, sparkling May morning, the meadow-larks will be roused to 
unwonted animation and sing far beyond their usual score of half a dozen notes.

According to Ridgway's Manual, we have six Orioles. Two of these are well-known Eastern birds, the others Western and Southwestern. The habits of the group are much alike wherever the birds are found, the variations such as the immediate surroundings have necessitated or suggested.

In the Eastern and Middle States everybody is familiar with the Baltimore Oriole. The bright orange-and-black plumage, the penetrating whistle, and pendent nests are of themselves sufficient to make the birds very conspicuous, but when we consider that they are fond of the proximity of man (strange taste) and often build their homes overhanging busy village streets, it is no wonder that everybody knows the bird as he does our strect sparrows, and has given it a long list of ridiculous names, as "Fire-robin," "Hang-nest," and "Golden-gabbler." The song naturally commands attention because of its shrill notes, that are so fife-like as to produce an unpleasant sensation. Then, again, there is a long, varied series of pleasing notes that are really charming, but in constant danger of being spoiled by the introduction of discordant shrieks.

Much has been written of the oriole's nest, and certainly it is the most conspicuous of the nests found in our woods. It is a long, narrow bag, that is securely fastened to a pendent branch of an elm or willow usually, and made of such materials as can be readily woven into a coarse fabric.

If you offer the birds bright-colored yarns they 
will not put them on the outside of the nest; but the whole structure is less elaborate now than formerly. They are more like cups suspended by the rims than cylinders. This, it has been suggested, has come about from the fact that long, slender nests concealing the sitting bird and inaccessibly placed are now not needed for safety, the birds so generally nesting near our houses, where their natural enemies are not found. I have seen one nest in an elm-tree but twelve feet from the ground and overhanging a part of a farm-yard where there was constant passing and repassing. When, on the other hand, you occasionally find a nest in a lonely spot away from any human habitation, there you will find the more elaborate structure, and placed where it cannot be reached except by the birds themselves.

A few days after the first appearance of the Baltimore orioles there comes to the same places, and prances about in the same lively manner, a dullcolored black and red-brown bird that we know at once is an oriole, but not the Baltimore. To my mind he is a great improvement over his gaudy and noisy cousin. Fine feathers do not always make a fine bird.

Its song has as many notes as the Baltimore, and none of them on the factory-whistle order. There is just the difference between the song of the Orchard Oriole and that of the Baltimore as between smoothness and roughness, as between the rattle of stones and the gliding of water over them. We would miss the Baltimore in summer, but it would be something like missing the bore we expected; not to have the orchard oriole would be a deprivation. 
The orchard oriole's nest is of simpler construction than that of the other species. Some that I have found were made wholly of pine-needles, and were placed in the upper branches of tall Weymouth pines. Other nests in deciduous trees were made wholly of flexible grasses neatly interwoven, but all were cups, and not deep at that.

During the summer the birds are not associated, although I have known an "Orchard" and a "Baltimore" to have nests in the same tree; but the young of the former and of the latter are found together prior to their autumnal flight to warmer regions.

The Rusty Grakle, or Blackbird, is a migrant only in the Middle States, coming in March and reappearing in October, and in the latter month we can always find an abundance of them in the tide-water marshes of the Delaware. Their summer home is in Northern New England and Canada.

Brewer's Blackbird is a Western species found from "Eastern Kansas and Minnesota to the Pacific."

\section{Dr. Coues says of them,-}

"Several kinds of Blackbirds are abundant in Arizona, but the present surpasses them all in numbers. ... They are eminently gregarious when not breeding."

We have now to briefly consider a bird as familiar to us all as the crow, and that is the Crow-blackbird, or preferably the Purple Grakle. They are both resident and migratory in the Middle States and resident southward. In New England the bird appears to be replaced by the Bronzed Grakle that is found west of the Alleghanies. The Grakle of the Middle States is purple when seen in the hand, and has an 
ivory-white eye that is very beautiful. When seen at a distance the bird appears of a uniform jetty black. Judging from the accounts of the earlier writers, they are not as abundant now as in the early years of the century. Wilson speaks of a flock of one hundred thousand birds. This is several points better than any recent experience can show. In early spring the grakles appear in little colonies, and choosing a cluster of trees that offers security, they build many nests in close proximity; and the care exercised in keeping their voracious offspring supplied with food shows how devoted they are to their own flesh and blood. From early morning until it is quite dark the parent birds pass out into the fields, and soon return with a grasshopper or fat grub, and then out again for more. This is kept up with a regularity that is interesting for several reasons. I have often timed them, and the period of absence from the nest is remarkably uniform. Having determined how many insects are brought to the nest in a given ten minutes, a very close calculation can be made as to the amount of food consumed in a "day" of about ten hours. It needs no slaughtering of scores of birds to determine such facts as these, and I am not sure if the eyes are not better than the shot-gun to determine the feeding habits of nearly all our birds. That grakles pull up sprouting corn can hardly be questioned, but if the corn be tarred they leave it alone, and while walking between the rows they feed upon cutworms innumerable. The doleful accounts of the destruction of the corn crop by these birds, as given by Wilson and repeated by Nuttall, 


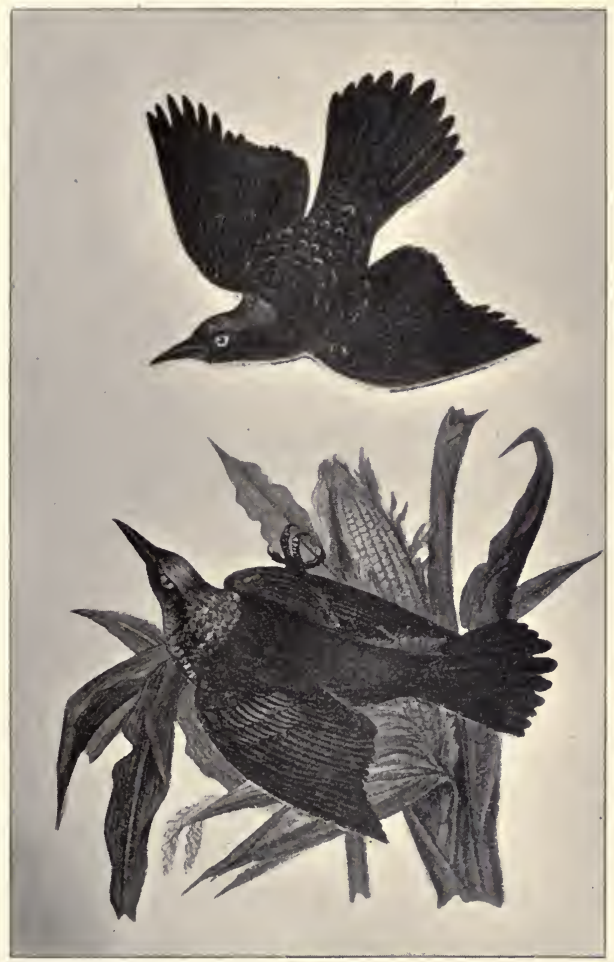

PURPLE GRAKLES. 

are ancient history, at least here in the Middle States.

It is a pleasant thing to hear these grakles twang their loose-strung harps. They slightly uplift their wings, spread their boat-shaped tails, and then utter the strange sound that is neither song nor chirp, but a metallic and sibilant sound combined.

At times these birds may be said to be quite aquatic in their habits. They run along the rivershore hunting food of every kind, for all is good grain that comes to their grist-mill, and have the same teetering walk and tilting of the tail as the sand-pipers exhibit when they walk upon the beach; but the grakles are good swimmers as well, and often light upon the water, swim a short distance, and rise up as easily as a duck; and, too, they can dip down gracefully and seize a morsel of food thrown over from a passing steamboat.

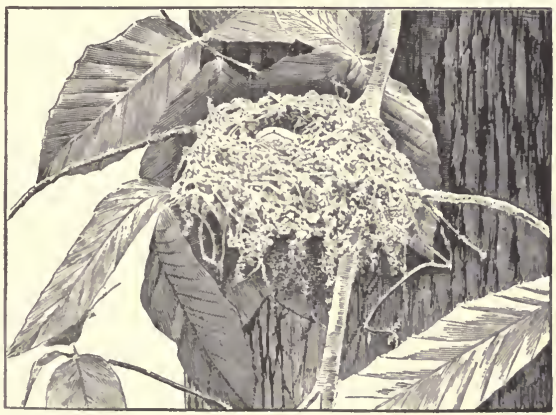

Nest of Acadian Flycatcher. 


\section{CHAPTER V.}

THE GOATSUCKERS, ETC.

$\triangle$ ND what now of that curious bird the WhipA poorwill? It is migratory, and the Delaware Indians said it was not safe to plant corn in the Delaware Valley until these birds had arrived; after that there would be no frost. And so now it is thoroughly delightful to hear for the first time, early in May, the song or cry of this bird, feeling assured that there will be no more frost. Without any intimation of its coming, as if it had dropped from the clouds, this bird finds a secluded nook in the woodlands, and while it is yet day sits as motionless as the lichen-patches that it so much resembles; but as the sun goes down and the dim uncertain light of the gloaming prevails, the bird is roused to activity, and then it is, calls out with ceaseless repetition whippoor-will, whip-poor-will. A pleasant sound at first, but as the summer wears away becomes intolerably monotonous.

The whippoorwill does not enter the Delaware Valley earlier than May I, so far as I have noticed, and remains until October; but during the close of its summer sojourn is more likely to be seen than heard, for as the day closes it occasionally flits through the air, and night after night passes without their uttering their monotonous refrain. During the day 
they squat closely at the side of a prostrate log or on it, but of late I have found horizontal branches of old apple-trees to be favorite places, the dense shade of an orchard where the branches of the trees interlock being nicely suited to their needs and replacing the shade of the forest primeval, now a thing of the past.

The nest is placed on the ground, if a little depression among dead leaves can be called a nest, and therein are laid two speckled eggs. The young are absurdly-shaped mud-colored balls when hatched, but very soon have their wits about them and move with much freedom before they learn to fly. The old birds at this time are excellent actors and can play the wounded bird to perfection; but do not flatter yourself that you can pick them up. They may appear to be at your fingers' ends, but are sure to be out of reach.

In very many respects the Night-hawk is a very different bird from the whippoorwill; certainly it is more active, even diurnal as well as crepuscular, and has no tiresome "song." It comes about the same time of year, and

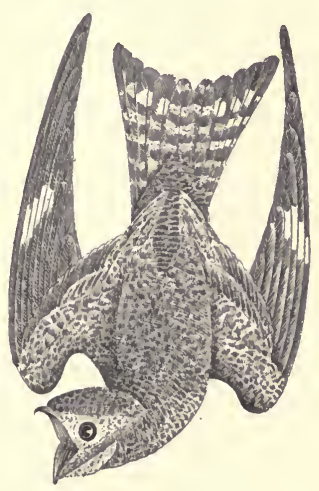

Night-hawk. stays as long, or perhaps a week or two later, a good deal depending upon the character of the weather. 
Like the whippoorwill, it lays its eggs directly on the ground (sometimes on the flat roofs of houses) and particularly in open stony pastures with a southern outlook.

In August and later they seem attracted to towns and their immediate neighborhood, and often dart down into the streets as familiarly as a chimneyswift. Late in the summer they seem to be almost gregarious, and sometimes a hundred or more will be at one time in sight. They are now migrating.

The Chuck-will's-widow is a Southern species that does not venture north of Virginia. Its habits are essentially those of the whippoorwill, the difference in the "song," as indicated by the bird's common name, being the most marked variation. Taken together, these are three most curious birds, and it is not strange that considerable superstition is connected with them in the minds of unlearned people.

There are four Swifts in the United States, allied in habits and familiar through their abundance to the people of the districts they inhabit. In the Eastern or Atlantic seaboard States the omnipresent Chimneyswallow is known to every one. It is a migratory bird, coming early in spring and staying until late. The statement of Nuttall that they all disappear about the first week in August is now quite an error and probably a slip of the pen. Warren records them as late as October 20 , and I have seen them as late as November Io. Their coming is fairly regular, and when here they at once settle into the routine that seems to us outsiders fearfully tiresome. They select their chimney (or a hollow tree in remote, unsettled places), 
and soon after make a nest of little twigs glued together securely against the bricks. They are busy enough when they have but themselves to feed, but a little later, when the eggs are hatched, they have more than double duty to perform, and from very early morning until very late at night they zigzag the air with tireless, rapid wing, and dart every few minutes into the chimney to feed the young birds. Perhaps they do get tired at times, for I have fancied they twitter less constantly then than in August or September when the young can take care of themselves,- - there are two broods, - and it is during clear September sunny afternoons and after sundown that these swifts show us what flight really means. They have aerial races then, generally three joining in the sport, and the celerity with which they dash down the pathless highways of the upper air is simply marvellous, and the faster they fly the louder they twitter. The food of these birds is, of course, insects, and the number they destroy in the course of a season is simply incalculable.

Early in May, when we begin to look for wild flowers in abundance and the fruit-trees are in bloom, the Humming-bird suddenly puts in an appearance and adds a charm to the landscape that remains until October I. They feed upon small insects and not wholly upon nectar, as is popularly supposed, and yet sweets are not by any means unacceptable. They are hot-headed little fellows and fight most fiercely at times, even occasionally with fatal results. They are not exactly gregarious and yet a good many will be found together. My study window that I at present 
The Birds About Us.

occupy is directly upon a village street. On the stone wall there is a trumpet-creeper that has grown about and above the sill, and when this fine oldfashioned vine is in bloom there is no dearth of humming-birds. They come and go continually while the sun shines, and the sound of their wings and funny squeaky voices is almost continuous. 


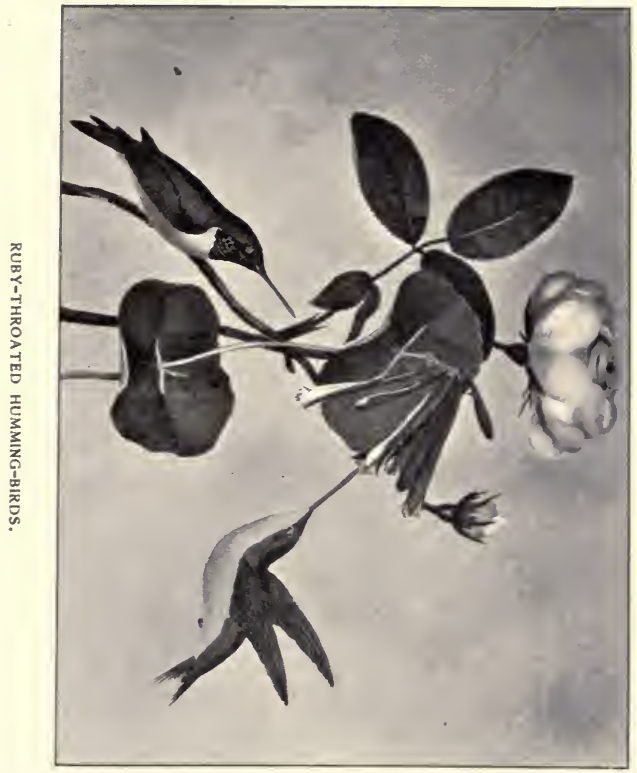





\section{CHAPTER VI.}

THE WOODPECKERS.

$A^{\mathrm{S}}$ a class the Woodpeckers live on trees and find beneath the bark. They can run over an upright trunk of a tree with great rapidity, and move, too, in a sidewise manner that is as quick as direct upward travel. They are not given to clinging, head downward, to the trees as does the nuthatch, but it is by no means an impossible position for them to assume. Their beaks are solid, sharp, and so fashioned that wood may be readily cut away, and this work so frequently indulged in has given rise to the common name, woodpecker. They nest in trees, cutting a deep hole in living or dead wood as they see fit, and without any lining other than a few fine chips in the very bottom of the excavation, lay therein a few pure white eggs. So fond are they of working in wood that they sometimes make elaborate nests in midwinter, and abandon them without so much as once resting there overnight.

As musicians, some of them are excellent drummers, but as vocalists, not one of our United States species is a success. They can call, squeak, squeal, and splutter, but I know of no other utterance not described by these forbidding terms. But as drummers they claim our attention. There come in course 
of time late autumn days when the leafless woods are silent. There is the warm sunshine on the forest floor, there is the lingering green of holly and cedar, but the day is dead. Not even the brilliant scarlet and golden berries of the bitter-sweet tempts any bird. It is all the bitterness of loneliness, - nothing of the sweet of company. The beauty of the Indian summer has led you out into a deserted world, and every thought is tinged with melancholy. You are ready almost at the outset to return, when suddenly, afar off, there is a rapid drumming. A low but resonant note fills the woods. The life you hoped to see and hear is returning. Listen! The loud chirps of hidden sparrows are a response. The woodpecker again and more violently beats his drum, and now a sleepy cardinal awakes and sounds a few clear fife-like notes in reply. When this has been your experience, as it has so often been mine, you will learn to love the music of even a woodpecker.

The largest and most superb of all the tribe is the rare Ivory-billed Woodpecker, that is now found only in "restricted localities in the Gulf States (including Florida) and lower Mississippi Valley." The probabilities are that it will soon be extinct, so far as the United States is concerned. It is too handsome not to tempt every collector, taxidermist, and millinery establishment in the country, and he who protests will be laughed at for his trouble.

In the Middle States and northward we have, all the year round, two little woodpeckers known as the "Hairy" and "Downy," and more usually in the country they are called "Sapsuckers," from the prev- 
alent notion that the sap of trees, in season, supplies them with the bulk of their nourishment. We will return to this subject again. The "Hairy" is the larger of these two species, being about nine inches in length, while the "Downy" is but little over six inches long. So far as my personal observation goes, it is not as abundant anywhere as the "Downy," and wholly absent from many wide tracts within its general range. It is a bird of timber land and not of the open country, and shows little disposition to accommodate itself to a new order of things. Cut down your trees and they will go to some more (to them) hospitable region. Wilson speaks of the hairy woodpecker as a lover of orchards, but when Wilson wrote it was not so long a journey from an orchard to a woodland tract.

But the little downy woodpecker is everywhere. There is not a tree too small for it to consider, and when trees fail altogether, it will climb over an old grape-arbor and be happy in so artificial a surrounding. They come fearlessly into town and visit every shade tree in the streets, and have been seen to peck at a fly on the wrong side of a window-pane.

When the warm weather fairly sets in, a pair of these little woodpeckers will hollow out a commodious nest in a dead tree and rear a brood that seem to be hungrier than most babies, considering the amount of food the parent birds carry to them.

Nuttall says, -

"These birds have a shrill cackle and a reiterated call, which they frequently utter while engaged in quest of their prey. In the au. tumn they feed on various kinds of berries as well as insects."

G $k$ 
I have seen them in winter bore into apples that were dried up and very hard, as I considered them, to get at the seeds, but never could determine whether they drank what little juice there might be left in the fruit. Very often their efforts would dislodge the apple, and I never knew them to follow it to the ground. An open squirrel-nest is sometimes visited in autumn, and the scattered white grubs that are among the accumulated shells of the nuts are, I suppose, the attraction. When deep snows cover the ground-not a feature of recent winters-these little woodpeckers will come to the barns and stables and seek shelter and food there. I have found them at times in cow-sheds and apparently weak from exposure and hunger, at least they were remarkably tame. Vegetable food under such conditions seemed very acceptable.

The Red-cockaded Woodpecker is a Southern bird, discovered by Wilson in North Carolina, and it is said to occasionally wander as far up the coast as New Jersey, and one or two examples collected near Philadelphia have been preserved.

The Arctic Three-toed Woodpeckers, on the other hand, are, as the name indicates, Northern species that do not wander as far south as the Middle States. Of course there are a few exceptions to all such rules, perhaps a good many more than we are willing to admit, but it is quite true that visits to the collections of local collectors sometimes prove "eyeopeners" to the professional ornithologist.

In the Northwest they are common. Dr. Cooper found them 
"quite numerous about Lake Tahoe. . . At the lake they were quite fearless, coming close to the hotel and industriously tapping the trees in the early morning and evening. ... I I noticed their burrows in low pine-trees. . . . I found them silent birds, though probably in the spring they have a great variety of calls."

\section{J. K. Lord records,-}

"Both when on the wing and when clinging against a tree it continually utters a shrill, plaintive cry. Its favorite tree appears to be the Pinus contorta, which grows at great altitudes. I do not think this woodpecker is found (in British Columbia) except on the hilltops."

The Yellow-bellied Sapsucker is a migratory bird, and seen in the Middle States usually only in the spring and autumn; but there are bits of territory in these States wherein the bird is accustomed to remain all summer and breed. There has been much discussion concerning the habits of this peculiar bird, for its anatomy is

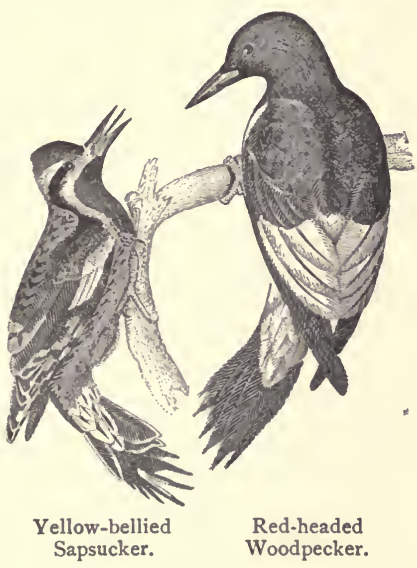
not that of other woodpeckers in some respects. That it is capable of doing an immense deal of harm to trees and does do it seems fully demonstrated, and although a great insect-destroyer, this 
is no adequate return for the damage of which it is the author.

Montague Chamberlain, in a note to Nuttall's account of this bird in his (Chamberlain's) edition of Nuttall, says,-

" The 'sapsucking' habit of this species, denied by some, . . . has been established by (the late) Mr. Frank Bolles.

"For several days Mr. Bolles almost continuously watched a number of these birds while they operated on trees, . . . maple-, oak-, birch-, and ash-trees, and drank the sap as it dripped from these holes. When one set of holes became 'dry' others were drilled, eight to sixteen on each tree, the new holes being made higher up than the old. Some of the birds spent about nine-tenths of the time in drinking sap."

In the face of such facts it is difficult to find any reason for not exterminating such mischief-makers. I have not found in New Jersey any one who has suffered the loss of trees through the attacks of these birds, even in the limited localities where they have been found nesting. Unlike other woodpeckers, this one is an expert fly-catcher.

In a remote corner of one of Pennsylvania's hilly counties, where superb hemlock-trees were still standing, and the ground was so rough and rocky that it was difficult even to clamber over it, I had the good fortune to spend the entire month of November, 1865. I led a wild life, wild as the wary fox, the surly bear, and timid deer. My bed was hemlock boughs, my shelter the overhanging rocks. While struggling to cross a rapid mountain brook, hidden in a dense growth of rhododendrons, I realized for a moment that I might be lost and called to my companions. The reply was a loud cackle or cackling 
laugh that thoroughly startled me. Looking up, I saw on a huge dead hemlock a Pileated Woodpecker, the "Black Log-cock" of which I had heard the barkgatherers speak. The bird had not heard me call, and commenced at once a strange rattling of the dead wood of the old tree, for it had no bark, and at times uttered a loud clicking sound, as a hen's cackle the moment she leaves her nest. Very soon another and then a third came, and the noise made by the three could, I think, have been heard a mile off. At a signal, or alarmed by the same real or fancied danger, they suddenly darted off, flying laboriously but rapidly down the rocky glen. Although I was near the same spot for many days after, I saw no more of them, but at night their call could at times be heard, and I was told that "they never slept unless the night was pitch dark." I do not, however, accept this statement as correct, and yet why should we doubt the assertions of those who have had every opportunity to observe birds and make a habit of doing so?

In June, I867, I rambled for several days in this same old woods and again saw these birds. There were two which I took to be mates, and this proved to be true, as a day later I found them again and saw the tree in which they had their nest. There were never two more noisy, wary, restless birds, and I had to content myself with glimpses now and then, and without a field-glass would probably not have seen them at all.

In April, 1879, I was more fortunate. In Linn County, North Carolina, I found them abundant and 
far less timid. I could get near enough to view them satisfactorily, and here they seemed, too, more deliberate. They detached enormous chips from dead trees, and made as much noise in their work as they did by the incessant click or cackle they found time to utter.

Wilson says, -

"The Pileated Woodpecker is not migratory, but braves the extremes of both the arctic and torrid regions. Neither is he gregarious, for it is rare to see more than one or two, or at the most three, in company. Formerly they were numerous in the neighborhood of Philadelphia, but gradually, as the old timber fell and the country became better cleared, they retreated to the forest. At present few of these birds are to be found within ten or fifteen miles of the city."

By "at present" he referred to eighty years ago, and the "ten or fifteen miles" must now be multiplied by ten at least, although stragglers occasionally are seen in settled districts. A century ago they were common in the great pine forests of New Jersey, but these have been so continually fire-swept, and so much of the larger growth cut out, that probably the bird is now wanting there.

The pileated woodpecker is also found on the $\mathrm{Pa}$ cific coast, and there, too, according to J. K. Lord, is "difficult to obtain from its shy habits, always hiding in the dark pine forests."

A splendid bird, but one no longer very abundant in long-settled districts, is the Red-headed Woodpecker. All the woodpeckers have a bit of red about their heads, but it often is but a mere patch, as if a slight scratch had been bleeding; but in this bird we have with glossy black and white plumage a brilliant 
red head and neck. It is a much more conspicuous bird than the all-red cardinal or black-winged tanager, and of late, if not always, the birds seem to know it and are shy, keeping well among the trees, and quite near their tops at that. This is a sad change and none to their liking. It is not so long ago that the red-headed woodpecker was a bird of the fields, and particularly of the old, weed-grown worm-fences; and he was an expert fly-catcher, and launched out after beetles as gracefully as a kingbird, and never missed his aim. He loved the old apple-orchards, and his presence there was as natural as the bloom in May or the ruddy fruit in October. Dr. Warren suggests that the demand for millinery purposes has brought about the change. Even our new dictionaries do not give us the words that are needed to comment on this matter, and probably the world will not wake up until the birds are gone altogether.

These birds are very fond of wild fruit, and Wilson says are excellent judges of apples; but they eat, as do all woodpeckers, any quantity of insects, and earn and always did earn what they took from the orchard.

The Red-bellied Woodpecker is rare in the eastern portions of the Middle States, but abundant westward. They appear to prefer the hilly regions, or have been driven back by the general destruction of the timber.

\section{Nuttall states,-}

“ His loud and harsh call of 'tshow, 'tshow, 'tshow, 'tshow, reiterated like the barking of a cur, may often be heard, through the course of the day, to break the silence of the wilderness in which his congenial tribe are almost the only residents. On a fine spring morning $I$ have 
observed his desultory ascent up some dead and lofty pine, tapping at intervals, and dodging from side to side, as he ascended in a spiral line; at length, having gained the towering summit, while basking in the mild sunbeams, he surveys the extensive landscape, and almost with the same reverberating sound as his blows, at intervals he utters a loud and solitary 'cur'rh in a tone as solemn as the tolling of the Campanero. He thus hearkens, as it were, to the shrill echoes of his own voice, and for an hour at a time seems alone employed in contemplating, in cherished solitude and security, the beauties and blessings of the rising day."

Perhaps because it is not so "smart" a bird; possibly because it has a good deal more common sense than other woodpeckers; but whether the one way or the other, the Golden-winged Flicker, or Highhole, means to hold his own in the land of his fathers,

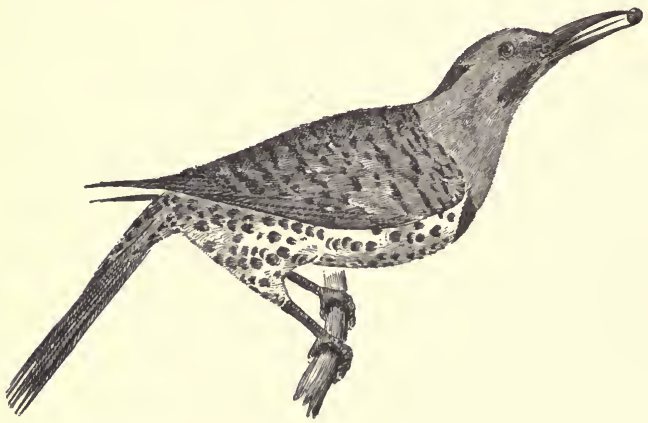

Flicker.

mar it as much as civilization may. If there are no trees it will take to the fences, and if needs be, it can run over the ground a good deal faster than any boy can unless he has been some time in training. But 
the time will never come when we will have no trees, and so the flicker will never be "put to it" for good nesting sites and a chance to drum and hammer to its heart's content.

In the Middle States these birds are both resident and migratory, and migratory in New England. In a general way they are all "woodpeckers," and you notice no characteristic traits when they are in the trees; but in August, when their nesting labors are all over, they often congregate in large numbers in the pasture meadows and then seem quite like another bird. They know that beneath the dry "chips," where the cattle have been browsing, are plenty of fat, black crickets, and, not disposed to thrust their beaks through these unsavory "chips," they deftly turn them over and seize one or more of the surprised insects. I have been told, but never have seen it, that when a "chip" is too large for one bird to manage, "two will tackle it and divide the profits." The voice of the flicker is peculiar, and its common name is derived from its most common utterance, which resembles that word rapidly pronounced and repeated. My own impression has always been that the bird said wake up, wake up, rapidly and often, and when heard about sunrise it certainly is a very suggestive, if not altogether welcome, cry. 


\section{CHAPTER VII.}

THE CUCKOOS, ETC.

WAT of our Cuckoos? There is found in
"Northern Mexico and contiguous portions of the United States, north to Western Indian Territory and Kansas, Southern Colorado, and California," a very curious and interesting bird known as the Roadrunner. As the name suggests, it is a ground-cuckoo, and except that it occasionally perches upon a low bush, is seldom seen except on foot. It is very fleet and is often chased by men on horseback, and gives evidence of excellent endurance, not being readily overtaken.

It is an expert fly-catcher, and feeds also upon lizards and mice. It is easily tamed, and under this artificial restraint proves to be an intelligent and amusing pet. The nest is loosely built of twigs in a low bush.

Very different are the two common cuckoos of the Eastern States: different in appearance, in all habits, and strictly arboreal. I can recall no birds that so seldom leave the trees, and have no recollection of ever seeing one upon the ground. These two cuckoos are known as the "Yellow-billed" and "Black-billed" Cuckoos; but probably a more common name is "Rain Crow," and a more absurd one would be 
hard to imagine. Their peculiar call certainly has nothing to do with any change of weather. They reach the Middle States in April, but late in the month, and they remain until late in September. Their coming is promptly recognized if we are on the lookout for birds, for although they have a knack of gliding silently through the trees, they are compelled to chatter at intervals, and the $k u-k u-k u-k-k-k$ $k u k-k u k-k o o$ they utter is quite unmistakable. Authors have pointed out in considerable detail the differences in the general habits of these two birds, but they have never been very apparent to me. Both are common, although the yellow-billed species is always the most abundant.

This cuckoo is said to be a more persistent nestrobber than the "Black-bill," but as a caterpillareater is much more prominent than as an egg-sucker. It is fond, too, of our wild red and white mulberries, and as this insipid fruit looks so much like a worm, I have often thought that perhaps the bird did not know the difference. Of course the robbing of birds' nests is an ugly record, but there can be no doubt that the immense number of insects destroyed by these birds outweighs any objection that can be urged against them.

A cuckoo's nest is a slovenly affair, and may be found in a tree or bush, high or low, and that young bird is fortunate that does not tumble out of bed long before it can fly. The big greenish-blue eggs do not seem to be highly prized by their owners, and for want of sufficient attention sometimes fail to hatch, but when the young birds have really put in an 
appearance the parents are fully aroused to their responsibilities and look well after them; supply in-

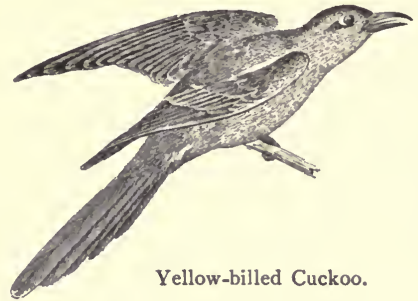
numerable caterpillars and every discoverable form of uncanny slug; and when you happen to go too near the nest, the old birds will go into hysterics, or make believe to,

hoping to completely fool you as to the whereabouts of the nest.

Wilson speaks of this habit as follows:

"While the female is sitting the male is generally not far distant, and gives the alarm by his notes when any person is approaching. The female sits so close that you may almost reach her with your hand, and then precipitates herself to the ground, feigning lameness, to draw you away from the spot, fluttering, trailing her wings, and tumbling over in the manner of the partridge, woodcock, and many other species. Both parents unite in providing food for the young. This consists for the most part of caterpillars, particularly such as infest apple-trees. The same insects constitute the chief part of their own sustenance."

The Black-billed Cuckoo has always been, in my experience, a lover of willow-trees that overhung the water. This, of course, is a mere coincidence, but I have never failed to find them, I believe, while wandering about the creeks that have so generally a row of pollards on one or both banks, or among the weeping-willows that fringe the mill-ponds. From trees on the water's edge the cuckoos will dart out 
at times and seize large butterflies, and when the broad wings of the victims flop about the captor's head, it is very amusing to see the bird try to reach the tree from which it flew. This is not accomplished in the most graceful manner at all times.

Passing by the Trogons and Motmots, that are more birds of Mexico than of the United States, we come to the Kingfisher as next in order, there being but one species in the United States as a whole, and the Texan Kingfisher, which is found only in a limited area on our southwestern borders.

In the Middle States the Common

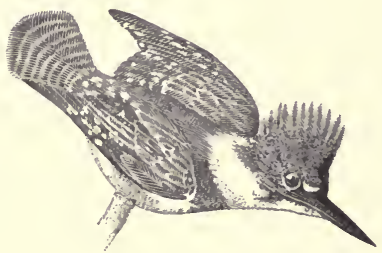

Kingfisher.

Kingfisher is both resident and migratory. When it remains in winter it sometimes roosts in the nest that was occupied during the preceding summer, but more frequently takes refuge in some sheltered nook of an old grist-mill, and fasts when the ice is over all the open water; but this is very seldom the case. In April those that migrated have returned, and the curious cry of the bird is a common feature of every locality where there is water. Nuttall speaks of it as "retiring," but I have found them of late eminently sociable. Many are found in remote localities, but this is because the fishing is good and not because mankind is more or less remote. It is a bird, of late, of our mill-ponds, and if there were 
enough of these " to go round," all the kingfishers would be near at hand. They seem quite content to come within the limits of large towns, provided there is an abundance of food and the ubiquitous small boy is not too inquisitive.

The following is Dr. J. M. Wheaton's account of the nesting habits of the kingfisher as observed by him in Ohio, and it is applicable to the bird wheresoever found :

"The nest of the Kingfisher is an excavation in the face of a high bank of a stream or side of an artificial excavation. The entrance is usually within a couple of feet below the top of the bank and extends inward, usually straight, but sometimes with an angle, from three to six feet. Usually no nest is made, but near the extremity the eggs are deposited in the midst of fish-bones disgorged and excreted. The eggs are from five to seven, usually six, nearly spherical, clear shining white, and of very dense texture. They measure I.30 by 1.05. The birds are very much attached to their nestingsite. One nest on the bank of a gravel-pit I have dug down upon for several successive years, and the birds are not yet inclined to desert the spot. Another bank occupied by these birds was removed by a freshet, and a large sycamore-tree which stood upon it was carried into the middle of the stream, where it remained with large quantities of earth adhering to the roots. In this earth the birds made a tortuous and difficult excavation, and successfully raised their young."

The Carolina Paroquet, which belongs to a different order from the preceding, but is next to it in the system of classification, will be but briefly considered. Ridgway, in the Manual, states:

"Formerly, entire Mississippi Valley, Gulf States, and Southern Atlantic States, north (casually ?) to Michigan, Maryland, or even to Albany, New York, regularly to Ohio, Indiana, Illinois, Nebraska, etc., west to Eastern Colorado and Texas; now nearly exterminated, 
and existing only in comparatively restricted and isolated localities in lower Mississippi Valley and Gulf States."

This is not pleasant reading. "Nearly exterminated" means that we have not had law enough of the proper sort to make extermination impossible. It is quite probable-is it not certain ?- that if any of the remaining parrots ventured into the old haunts they would be immediately slaughtered. This is the usual fate of rare birds, and the professional ornithologists are more at fault than the loafers. 


\section{CHAPTER VIII.}

BIRDS OF PREY.

THERE is much in mere bigness, and I am not looked upon the eagle and the vulture as the very highest types of bird-life, and that people generally were more impressed with a regal falcon than a timid thrush; and in spite of all biological disquisition and learned anatomical treatises and evolutionary philosophy, a bird that outflies all others and preys upon others will be held to be the better bird, and so prove by what it accomplishes that which the systematist denies concerning him. Certainly on viewing bird-life as we ordinarily see it, and particularly so in this country, we are more impressed by a hawk than a sparrow. Their relative sizes have not all to do with this. The hawk asserts himself, thrusts himself upon our notice, and the timid sparrow cowers in his presence. We never forget this, and naturally in studying the birds about us turn from power to weakness, and not from the humble stand-point glance upward towards the powerful; and yet the sparrow and the thrush have a standing in the bird-world that is far more exalted than that of the eagle, falcon, or even the huge king vulture.

We cannot always forget that these birds, except the vultures, are murderers, as we call them. We know 


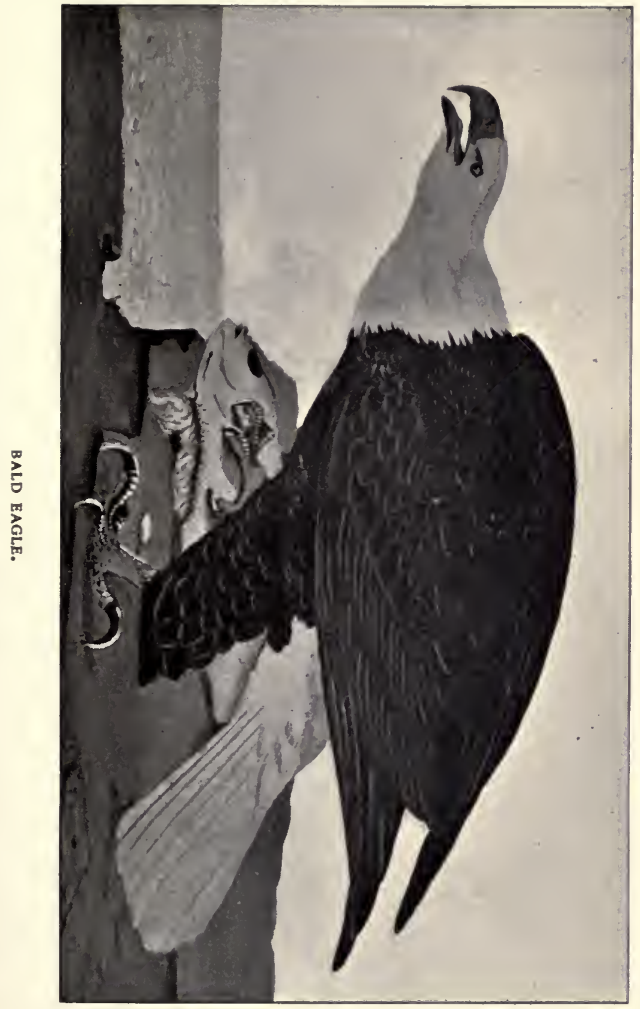



that a hawk will kill a thrush, and so condemn it; but the thrush that eats an earthworm goes scot-free. Of course in this, as in all else, man is very inconsistent; but when we simply see the hawk hovering above an uncared-for mouse, or mark the eagle as he flies directly towards the sun, or follow the manœuvres of falcons that chase each other until above the clouds, and swooping earthward with lightning speed, just clear the ground and rise with fixed pinions to the upper air, we are so filled with honest admiration that the so-called bad qualities are quite overlooked. Birds of prey may be low in the scale of the systematist, but forever they will remain the birds of birds.

There are three groups into which this class is divided, and we all recognize the differences at a glance: the Vultures, the Falcons, and the Owls.

Vultures, while in a sense birds of prey, are carrion-feeders, and this feature, while it makes them repulsive, at the same time causes their usefulness to be recognized, and many of them are almost domesticated, living in our towns and giving as little heed to the people about them as do our poultry. Being unmolested, they are tame, and that might be applied to a great many other birds, - that is, it is possible to have many birds now exceedingly wild become equally tame, equally familiar. I have experimented in this direction for so many years that I am positive the assertion is warranted. Birds, as a class, it must be remembered, are very intelligent. They carefully study the status of affairs, and learn to discriminate between friends and foes. Make a place safe for birds and the birds will find it out and occupy it. 
In the United States we have three vultures, of which the one characteristic of the Pacific coast is much the largest. Ridgway says of it, " now much reduced in numbers and extinct in many localities where formerly abundant."

Lewis and Clarke refer as follows to this bird:

"The buzzard is, we believe, the largest bird of North America. One which was taken by our hunters was not in good condition, and yet the weight was twenty-five pounds. Between the extremity of the wings the bird measured nine feet and two inches. . . . It is not known that this bird preys upon living animals: we have seen him feeding on the remains of the whale and other fish thrown upon the coast by the violence of the waves. This bird was not seen by any of the party until we had descended Columbia River below the great falls."

The vulture common to the Middle States and southward is known almost everywhere as the "Turkey-buzzard." Dr. Coues says our birds are more sluggish and have nothing of the spirit of European vultures, and I can well believe it, for the turkey-buzzard is one wherein enchantment is in proportion to the distance, so far as the spectator is concerned. As a bird of the air, circling for hours with no apparent movement of the wings, this bird is certainly the embodiment of grace; as a bird of the ground, surfeited with unsavory mutton, unable to fly and scarcely to reach the top rail of a fence, the bird is the picture of helpless, gluttonous stupidity.

In the Middle States-and they are rare northward -these birds are both resident and migratory, and being protected by law, are quite tame in some localities. Wherever sheep are raised the "turkey-buzzard" is sure to be found, but I have never known of 
their attacking them. Certainly the farmer does not concern himself about such a possibility. If young animals are attacked they are very helpless and have probably been abandoned as dead. It may be that they do not prefer putrid flesh, but they have been known to be so extremely deliberate in eating a skinned carcass that it was very "loud" before the bones were picked clean.

The discussion whether the sense of smell or that of sight is the vulture's guidance in finding its food has been brought to a close of late by the present general admission that they are chiefly guided by their piercing eyesight. Of course we will always meet with those who will maintain the contrary. Every positive statement is met thus, even the simplest and most obvious facts being daily contradicted. It is pure kindness to the bird that it has no keen sense of smell, and the law that has operated and is operating to bring the varied forms of life into existence could never have evolved a sensitive-nostrilled carrion-feeder. The food must be sweet or the sense of smell deadened. The conditions that operated to produce an appetite for carrion, or even a willingness to eat it, called necessarily for a loss of the sense of smell.

I spent the greater part of the month of September, I888, in Adams County, Ohio, encamped at the "Serpent Mound." The turkey-buzzards were extraordinarily abundant, and I was then struck with two peculiarities I had never noticed in these birds as I had observed them in New Jersey. They were continually croaking, and almost as distinctly as crows; and when the water in Brush Creek was low 
-about every other day-they would wander about the flat stones that formed there the bed of this apology for a creek and appeared to be hunting some kind of living food. They therefore appeared in a new rôle, and I gave the matter considerable attention until I found that the lodged carcass of a drowned calf was the attraction, and only at certain stages of this creek, that rose and fell with every petty shower, could they get a chance to nibble at it. The incident showed, I thought, that food was very scarce, and they must indeed have very keen eyesight to have found this tidbit, hidden as it was among rocks at the foot of a steep wooded cliff.

The Black Vulture is the more Southern species, and is a common feature of many Southern cities as well as the country, and depended upon to some extent as a scavenger. Nuttall's account is as follows:

"Their flight is neither so easy nor so graceful as that of the Turkeybuzzard. They flap their wings and then soar horizontally, renewing the motion of their pinions at short intervals. . . . In the country, where I have surprised them feeding in the woods, they appeared rather shy and timorous, watching my movements alertly like hawks, and every now and then one or two of them, as they sat in the high boughs of a neighboring oak, communicated to the rest, as I slowly approached, a low bark of alarm or waugh, something like the suppressed growl of a puppy, at which the flock by degrees deserted the dead hog upon which they happened to be feeding. Sometimes they will collect together about one carcass to the number of two hundred and upward, and the object, whatever it may be, is soon robed in living mourning, scarcely anything being visible but a dense mass of these sable scavengers, who may often be seen jealously contending with each other, both in and out of the carcass, defiled with blood and filth, holding on with their feet, hissing and clawing each other, or tearing off morsels so as to fill their throats nearly to choking, and occasionally joined by growling dogs, - the whole presenting one of 
the most savage and disgusting scenes in nature, and truly worthy the infernal bird of Prometheus."

This Southern vulture is rarely seen in the Middle States, a straggler now and then being recorded, but inland it goes quite as far north.

As a class the hawks are certainly more attractive than vultures, and there is no more graceful bird, when flying, than the Swallow-tailed Kite, a bird of the "tropical and warm-temperate portions of continental America," and a visitor to the interior States, along the Mississippi River and eastward to Ohio. It is of rare occurrence in Pennsylvania, but is recorded also of New Jersey and New England.

The habits of the bird are such that it deserves encouragement, feeding as it does on insects, snakes, lizards, and such forms of animal-life " as must necessarily be held in check;" but the quotation calls for some comment, for both snakes and lizards are extremely useful, the former in keeping down the mice, the latter in destroying insects. It is unfair to overlook the good accomplished by unattractive forms of life.

\section{According to Wilson,-}

"The Swallow-tailed Hawk retires to the south in October, at which season, Mr. Bartram informs me, they are seen in Florida at a vast height in the air, sailing about with great steadiness, and continued to be seen thus passing to their winter-quarters for several days. They usually feed from their claws as they fly along. Their flight is easy and graceful, with sometimes occasional sweeps among the trees, the long feathers of their tail spread out, and each extremity of it used alternately to lower, elevate, or otherwise direct their course."

The Blue or Mississippi Kite is a bird strictly of 
the Southern States. Its splendid flight-power makes it an attractive bird, and in soaring it often reaches an altitude equal to that attained by the turkey-buzzard. It feeds upon insects, lizards, snakes, and such small fry rather than upon birds.

In Florida occurs the Everglade Kite, a bird discovered in recent years as an inhabitant of that penin. sula. It is stated by W. E. D. Scott that

"their food at this point apparently consists of a kind of large fresh-water snail which is very abundant. . . They fish over the shallow water, reminding one of gulls in their motions; and having secured a snail by diving, they immediately carry it to the nearest available perch, when the animal is dexterously taken from the shell without injury to the latter."

Those who are familiar with wide reaches of meadows in the Middle and New England States must often have seen a broad-winged hawk, of large size, swoop gracefully over the tall grasses, and with quick motions of the wings appear to sweep the tops of the reeds and bulrushes, as if to start from their lurking-places whatsoever of wild life might be hiding there. This is the Marsh-hawk. The male bird is, when matured, of a uniform pale-blue color as seen flying, and the female rich brown, with a white band at the base of the tail. In August, when the bobolinks-now " reed-birds" - and red-winged blackbirds come to the meadows by the thousands, these hawks are ever ready to snap up the unwary or weakly ones, and having learned the significance of a pot-shooter's gun, have been seen to swoop down and carry off many a wounded bird. Mice, too, are captured in great numbers, and this fact should commend the 
bird to all who live in the country. So eager, at times, are these hawks for mice, that they tear open their run-ways in the grass and so find them when otherwise they would have escaped. The marshhawk does not confine himself to the lowlands. They scour our upland fields for mice and so do a vast amount of good, for there can be no question but that our clover-fields sadly suffer from an excess of this pest, a condition that would not obtain were it not for the senseless prejudice against snakes.

Dr. Coues says, -

"The Marsh Harrier belongs among the 'ignoble' birds of the falconers, but is neither a weakling nor a coward. . . . Still, under ordinary circumstances, its spirit is hardly commensurate with its physique, and its quarry is humble."

The Sharp-shinned Hawk is not likely to have any friends among the farmers, and at this we cannot wonder. Its impudence would be against it even if it did no harm, but its fondness for young poultry is undeniable. I was told the following by an old lady some years ago, but do not believe it, as the imagination of the narrator was known to be lively. She said that finding a brood of young chickens some distance from the house, she gathered them up in her apron and was about to start home, when a sharp-shinned hawk-a cunnin' little blue hawk, she called it-dashed down and took one from her lap.

These small hawks vary greatly in numbers in some localities. I have known them to be very abundant and to work sad havoc among the small birds of the neighborbood, and then to become very rare, almost none being seen for a year or more. While 
resident in the Middle States they are more generally noticed in the autumn and winter, and seem to follow the flocks of tree-sparrows and Peabody-birds.

Dr. Wheaton's account of his observations of this hawk is most interesting:

"The sharp-shinned hawk is one of the most daring and dashing of the family, frequently and successfully visiting the barn-yard for food, and often attacking birds of nearly its own weight. Sometimes, however, he fails to obtain his prey, either from over-confidence in his own abilities or under-estimation of the powers of his victim. I once saw an adult bird of this species pounce upon a meadow-lark quietly feeding upon the ground. By some means the attack was only partly successful, and the lark hopped about for a few moments with the hawk upon his back. The ridiculousness of his position seemed to disconcert the hawk, who relaxed his grip, only to find himself attacked by the bill and claws of his victim. Then followed a fierce fight with claws, bills, and wings, in which both contestants appeared equally active and determined. Finally the combatants separated, the hawk flying in one direction, disappointed, dejected, and disgusted, the lark in another, recovering his breath by extraordinary cries of alarm and distress.

"The nest of the sharp-shinned hawk is usually placed in trees, sometimes on rocks. The eggs are white, variously shaded, thickly marked with different shades of brown. They measure about 1.45 by 1.15."

Cooper's Hawk, or Chicken-hawk, as you will, is larger than the preceding, and with the increased size goes increased daring. I have seen one of these birds swoop down upon a decapitated chicken within five paces of the man who was waiting for the chicken to bleed. Dr. Warren says, "For impudent daring this species, without doubt, ranks pre-eminent among the raptorial genera." In general habits it does not differ essentially from the preceding.

The Goshawk is not a common species anywhere. 
It nests in high mountainous regions and north of the United States, and in the river valleys of the Middle States is seen only as a winter visitor. It is a beautiful hawk, but when seen sitting on a dead tree, or slowly flying over the river or flooded meadows, does not suggest that it is really a fiery, high-spirited, or " noble" falcon.

The Red-tailed Hawk, or "Hen-hawk" of the farmers, is too well known a bird to need minute description. It is that fine old hawk that sails in great circles high in air and calls at times to its mate with a shrill scream that startles every chicken and causes chanticleer to look about and caution the hens.

The hen-hawk, or red. tail, may be "rather inactive" sometimes, but there is plenty of "dash" about him when occasion calls for it. This is not displayed in the prosy matter of procuring food, but is an affair of play, perhaps, when, almost out of sight, a pair of them have what

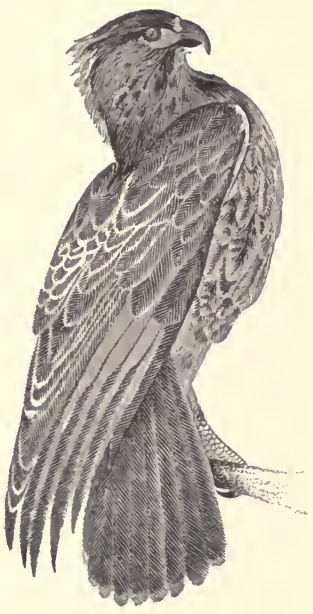

Red-tailed Hawk. appears through the telescope to be a rough-andtumble fight.

The migrations of these birds have often been de- 
scribed. Where do so many hawks come from ? is the question usually asked when they wheel through the air hundreds at a time, and for hour after hour.

The Broad-winged Hawk is not as well known a bird as the red-tail. It is only a winter visitor in New Jersey, I think, but Dr. Warren says it is a resident in Pennsylvania. I have noticed it in November and later, but it practically disappears in early spring, at least from the tide-water portion of the Delaware River Valley.

Dr. Warren says, -

"When in quest of food its flight is in circles. At times, when circling like the Sparrow-hawk, it will stand for an instant beating the air and then descend with great velocity upon its prey, which it secures, not in its descent, but as it is on the rise."

In midwinter, when the meadows are firmly frozen, I have often seen these hawks walking over the flats at low tide, but could not determine what particular kind of food, if any, they were in search of. When disturbed they rose leisurely and perched on a dead tree or an exposed limb of a living tree, and both when leaving the ground and when alighting they utter a rather prolonged, mellow whistle that is pleasing, and very different from the cat-like scream of the red-tailed hawk.

The Red-shouldered Hawk is more generally known as the Winter Falcon; but it has not been my experience that the people living in the country were given to discriminating between these large hawks, calling them by the same name and attributing the same objectionable habits to them all, and no amount of argumentation will ever avail; while the birds 
remain with us persecution will go on, and farmers otherwise intelligent will take pride in ornamenting their barns with hawks, owls, and crows indiscriminately slaughtered. The truth may be mighty, but it does not always prevail. Here, in the case of this bird, we have a mouse- and grasshopper-hawk that does not eat one chicken in a year, and yet it is not safe unless out of gunshot.

Dr. Wheaton says that this hawk visits the barnyard (that is, takes a chicken now and then), but I am very strongly inclined to doubt it. Possibly there was some other attraction. Dr. Warren defends it, and I know it is a capital mouser, and what more in its favor need be said?

It is a common impression that "Feather-boots" and the Black-hawk are quite different birds, and there does appear to be a difference besides the one of color, and that is the true Black-hawk is a more wary bird, acting as if it knew that in the eyes of a taxidermist, if no other, its skin had a special value. These two forms of the one species come to the Middle States quite often as early as November I, and from that time on you can generally find them perched upon hay-stacks, or taking up a position on some lone tree from which there is an unobstructed view of the fields below, and if not disturbed the same bird will stay all winter, provided the supply of mice does not run short.

They are essentially a harmless bird, and seem to have impressed their real standing in the world upon the minds of many people; and certainly they are an ornamental feature of the winter landscape. Stand- 
ing out boldly against a background of untrodden snow, or the cold gray sky of a winter day, they are sure to command attention. Their position then is that of dignified repose; but let a mouse stir in the grass beneath them, or dainty vesper mice venture from their bush nests in the smilax, and instantly this "sluggish, heavy" hawk is all activity.

Audubon's account of this bird runs, in part, as follows :

"When not alarmed it usually flies low and sedately, and does not exhibit any of the courage and vigor so conspicuous in most other hawks, suffering thousands of birds to pass without pursuing them. The greatest feat I have ever seen it perform was scrambling at the edge of the water to secure a lethargic frog. They alight on trees to roost, but appear so hungry or indolent at all times that they seldom retire to rest until after dusk. Their large eyes, indeed, seem to indicate their possession of the faculty of seeing at that late hour. I have frequently put up one that seemed watching for food at the edge of a ditch long after sunset."

The Golden Eagle is now one of those rare birds that, if seen, becomes the talk of the neighborhood, and one is never shot but the fact is recorded in the village paper as a wonderful event. The probabilities are that in Indian times they were abundant during the winter along our river valleys, and not unlikely they were resident. Even so recently as 1800 (I have manuscript records) they were observed, as well as the Bald Eagles, to follow the enormous flights of wild ducks in November, that were then a characteristic occurrence in the tide-water portion of the Delaware Valley. At present this eagle is not uncommon along the sea-coast in winter, but is only seen singly, 
and it is rather seldom that they come inland, unless it is to the mountainous regions.

Of course so bulky a bird preys upon animals and birds of large size, and Dr. Warren has given an amusing account of one kept in confinement, which very readily despatched cats of the largest size and ate a very considerable portion of them.

Lewis and Clarke found this bird on the Pacific seaboard, and remark concerning it,-

"This bird is feared by all his carnivorous competitors, which, on his approach, leave the carcass instantly on which they had been feeding. The female breeds in the most inaccessible parts of the mountains, where she makes her summer residence, and descends to the plains only in the fall and winter seasons. The natives are at this season on the watch, and so highly is this plumage prized by the Mandans, the Minnetarees, and the Ricaras, that the tail-feathers of two of these eagles will be purchased by the exchange of a good horse or gun."

Everybody is supposed to know the whole history of the Bald Eagle, and certainly the adult bird is always recognized at sight. The glistening white head and white tail mark it at once as the eagle, and I am not positive that the bird possesses any particularly interesting phase of habit or character. It is neither brave nor cunning, and when the fish-hawk will provide it with fish it is quite willing that it should do so.

J. K. Lord found them stupid to a marked degree on the Pacific coast in winter. He says,-

"They collect, young and old together, round the Sumass Lake, and as the cold becomes intense they sit three and four on the limb of a pine-tree, or in a semi-stupid state, all their craft and courage gone, blinking and drowsy as an owl in daytime. 
"I have often, when walking under the trees where these halftorpid monarchs of the air sit side by side, fired and knocked one out from betwixt its neighbors without causing them the slightest alarm. . . This eagle is by far the most abundant of the falcon tribe in British Columbia, and always a conspicuous object in ascending a river; he is seated on the loftiest tree or rocky pinnacle, and soars off circling round, screaming like a tortured demon, as if in remonstrance at such an impudent intrusion into its solitudes."

The Gyrfalcons are circumpolar birds, and one, the Gray Gyrfalcon, comes within our northern boundaries in winter. They are superb birds, particularly the white one, which is often immaculate, but usually with some dark markings.

Nuttall says of one variety of the gyrfalcon,-

"Next to the eagle, this bird is the most formidable, active, and intrepid, and was held in the highest esteem for falconry. It boldly attacks the largest birds."

The Duck-hawk, or, as we sometimes hear it called, the Peregrine Falcon, is only common in limited localities, but may be found occasionally in every part of the continent. It has not been long since it was found nesting in a hemlock near the Delaware Water Gap in Pennsylvania, and "up" the river they seem to remain until early autumn, when they come "down" and are found sparingly about tide-water all winter, but especially do they seek the salt marshes and the sea-coast. Dr. Cooper says of one he saw on the Pacific coast, "I have seen one pursue a swallow, and, turning feet upward, seize it flying with perfect ease." The common name duck-hawk comes from the fact that this bird preys upon wild fowl, and being so powerful and active, it can easily strike down a flying duck. 


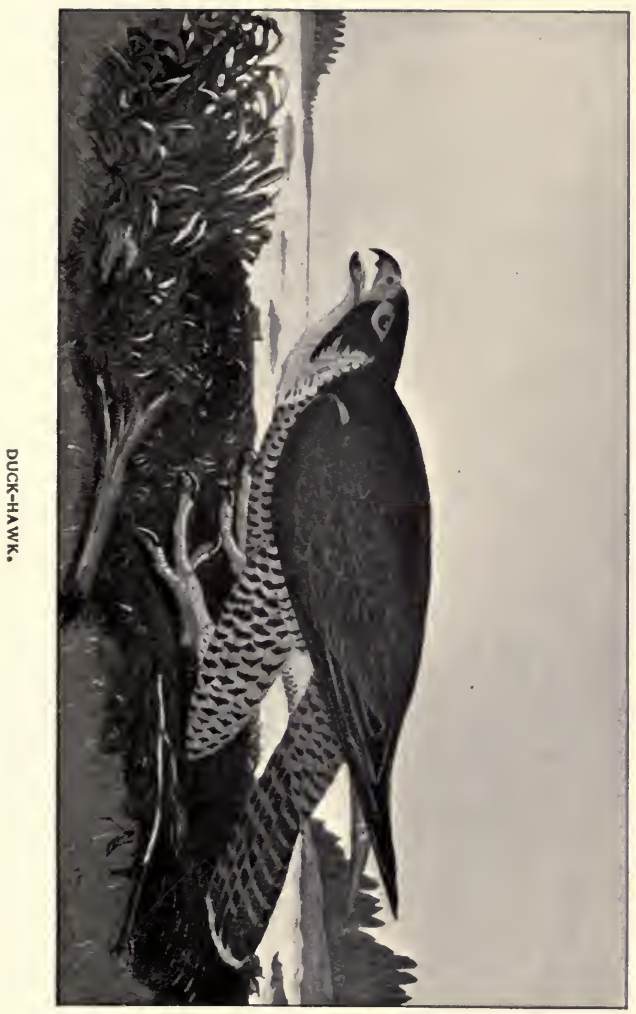



A much smaller and far more destructive bird is the common Pigeon-hawk, also a true falcon, and abreast of any of its fellows in all falconine traits. It is a northern species that comes southward in autumn, and as single birds, or in pairs, wander about where there are small birds in abundance. They are very fatal to the flocks of horned larks, chase flocks of blackbirds until they scatter them, and have been known to enter dove-cots and destroy the pigeons. Wilson supposes that they do not winter in the Middle States, but this is an error.

The Sparrow-hawk is everywhere, and equally happy whether the thermometer registers zero or $100^{\circ}$ in the shade. Give it a chance to go mousing and it asks nothing, except perhaps an opportunity to vary its diet with a sparrow.

I do not know that these beautiful birds care much for dense forests, and I seldom have seen them in our great tide-water marshes; but is there a field in the whole land over which, at some time, they have not hovered? Their flight is not ma-. jestic like the eagle's, nor as erratic as the swallow's, but there is a grace in their movements, a general "at-homeness," if I may coin the word, in the air that is

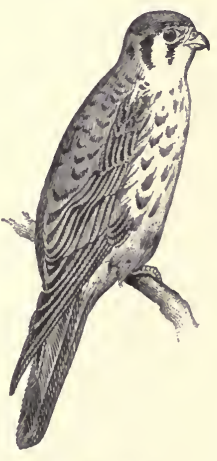

Sparrow-hawk. delightful to witness. Darting with apparent recklessness across the field, suddenly the bird stops, 
pauses motionless in mid-air, and then with a quick vibrating of the wings remains in the one position until satisfied. No! it was not a mouse that time, and on he goes. At short intervals this poising above the ground is followed by a sudden earthward swoop, but the bird comes up again with empty talons. Again and again this happens, and mouse the first is well digested before mouse the second is captured. The "unerring aim" is all moonshine, but there are plenty of lucky swoops, and never a sparrow-hawk went hungry for long.

These little falcons build in trees, using some commodious hollow that perhaps an owl has occupied before them, and here they lay pretty eggs and raise an interesting brood. When nearly ready to fly the young may be tamed thoroughly, and make very amusing but somewhat troublesome pets. One that I had was allowed to alight upon the top of my head, and, bending over, make believe to kiss me. This habit led to perching upon the heads of strangers, and when at last it carried off my uncle's wig and left it dangling in the top of the tall cypress, well out of reach, it was decided that a tame sparrow-hawk might be a nuisance.

Dr. Coues says of this bird, very truly and descriptively, -

"The prettiest and jauntiest of our hawks and yet no prig; a true falcon, if a little one, with as noble mien and as much pluck as the hest among his larger brethren, we can but admire him."

It seems scarcely necessary to enter into any details concerning the familiar Fish-hawk. Wherever they are found they are recognized as harmless,-as 
an addition, indeed, to the landscape; and the hosts of song-birds that seek cover when other hawks come in sight pay not the slightest attention to this one. Brief extracts from Wilson sum up the life-history of this bird:

"This formidable, vigorous-winged, and well-known bird subsists altogether on the finny tribes that swarm in our bays, creeks, and rivers, procuring his prey by his own active skill and industry, and seeming no further dependent on the land than as a mere restingplace, or, in the usual season, a spot of deposit for his nest, eggs, and young. ... .

"The Fish-hawk is migratory, arriving on the coasts of New York and New Jersey about the twenty-first of March, and retiring to the south about the twenty-second of September. Heavy equinoctial storms may vary these periods of arrival and departure a few days, but long observation has ascertained that they are kept with remark. able regularity. ...

"The first appearance of the Fish-hawk in spring is welcomed by the fishermen, as a happy signal of the approach of those vast shoals of herring, shad, etc., etc., that regularly arrive on our coasts and enter our rivers in such prodigious multitudes. . . .

"The nest of the Fish-hawk is usually built on the top of a dead or decaying tree, sometimes not more than fifteen, often upward of fifty, feet from the ground."

The nest, of late years, has been found occasionally placed directly upon the ground.

We now come to a strongly-marked family of birds that have always attracted much attention to themselves, principally because their active day is our night. It is not true of these birds-the owlsthat they can only see when we cannot, and that they are only active when the day is done. There are some that are diurnal, and the others are more strictly crepuscular than nocturnal. An owl is by no means helpless if driven from his retreat at noon- 
tide, but is, of course, not the alert, active, intelligent bird that we see voluntarily coming out in the gloaming, and with great, staring, but not stupid, eyes, surveying the land prior to a night's hunt for mice or small birds.

Ridgway's Manual gives us eighteen species of owls, and the inevitable variety bobs up on nearly every possible occasion. His list commences with the beautiful Barn-owl, a cosmopolitan bird; or at least the various "species" of barn-owl are so much alike that there is no danger of mistaking them for any other. They are smooth-headed, straw-colored, and richly sprinkled with pearly spots; by these signs ye may know them.

The distribution of this owl over the United States is somewhat irregular, and in New England it is rare, and even wanting in many districts. It was accounted rare, too, in the neighborhood of Philadelphia some years ago, but appears to be pretty common now in Central New Jersey, and I suppose also in Eastern Pennsylvania. Warren states that he has not found it breeding in this part of the State, but Gentry has, and I have found several nests on my own farm in Mercer County, New Jersey. These nests were all in hollow trees (old oaks), and in one instance the birds and their brood remained during an entire year. Another nest in the same tree was broken up and one of the old birds captured, but the bereaved widower (or widow) soon got another mate and was to all appearances happy as ever.

The most far-reaching, shrillest scream that I have ever heard uttered by a bird was made by one of 
these owls when captured. The food of the barnowl is mice, and almost exclusively so, and it need not be said, therefore, that it is not only a harmless bird, but an eminently useful one.

The Long-eared or Cat-owl is a well-known species that spends the day in a hollow tree or in dense evergreens. The cry at night has been fancied to resemble that of a cat, hence one of its common names. Nuttall speaks of the cry as plaintive or a " hollow moaning," adding that when many birds are together the sound is "troublesome." We should think it might be.

The following from Warren's "Birds of Pennsylvania" is not only instructive but suggestive. A correspondent informs the author that

"For over twenty years I have had congregated in my lawn from fifty to seventy-five owls. They are peaceable and quiet; only on rare occasions would you know one was about. On dull days and foggy evenings they were flying about in all directions. Never in all that time have I missed any poultry or have they inflicted any injury on anything of value.

" The first I noticed of their presence was the discovery of quite a pile of what appeared to be mice hair and bones, and on investigation found the Norway fir was the roosting-place of to me at that time a vast number of owls. They had ejected the bolus of hair and bones apparently of an army of tree-eating destructive mice, aiding the fruit-grower against one of the worst and most inveterate enemies. . . Their merits would fill sheets, the demerits nil."

\section{Dr. Warren remarks,-}

"Unhappily, during the past four or five years there has been a rapid decrease in the number of these birds in many localities in Pennsylvania; this diminution, I judge, is largely due to the fact that the stuffed heads of these harmless and beneficial owls make an attractive ornament for lovely woman's head-wear." 
The Short-eared Owl is a bird of very different habits, but equally harmless and beneficial. It is largely migratory and to a limited extent resident. Its common name of Marsh-owl is an appropriate one, for these birds appear annually in considerable numbers in the reedy flats and low meadows, and have learned to vary their ordinary diet with a wounded reed-bird now and then. I have often been startled by having one of these birds get up directly in front of me with a broad spread of wing and a grunt that made me for the instant uncertain whether the bird was an owl or a bittern. In the lower or tide-water meadows of the Delaware River this owl occasionally remains throughout the year and nests here. Their nests, under ordinary circumstances, are placed upon the ground, but in one instance, in a huge hollow of an old maple, I found the nest on the bottom of this natural excavation. The opening leading to it was very large, and the whole surroundings in nowise suggested the dark hole that would be chosen by a screech-owl or a sparrow-hawk.

The Barred Owl is not common in all localities, and if there is not considerable uncleared land in which to harbor, is only a casual visitor; but the huge fellow with his pale face and black eyes is not forgotten when we have once seen him. As might be inferred from the size of this owl, it is not averse to a pullet for a meal, and so has brought down upon its head the condemnation of the poultry-keeper; but the damage done in this way is unquestionably greatly exaggerated, and, of course, the good done in destroying mice is held of little or no importance. 
The Great Gray Owl of the north is the largest of our owls. If it is seen at all in the United States, it is as a straggler during winter. Several have been recorded as captured in New England and in Pennsylvania, and Dr. Wheaton mentions its occasional occurrence in Ohio.

"At Hudson's Bay and Labrador these owls reside the whole year, and were found in the Oregon Territory by Mr. Townsend. They associate in pairs, fly very low, and feed on mice and hares, which they seize with such muscular vigor as sometimes to sink into the snow after them a foot deep. With ease they are able to carry off the alpine hare alive in their talons. . . . It is common on the borders of Great Bear Lake, and there and in higher parallels of latitude it must pursue its prey during the summer months by daylight. It keeps, however, within the woods, and does not frequent the barren grounds like the Snowy Owl, nor is it so often met with in broad daylight as the Hawk-owl, but hunts principally when the sun is low."-NutralL.

The Acadian Owl is the smallest member of the family found with us. It is more nocturnal than many others of the family, and this, together with its size, renders its discovery difficult.

In Central New Jersey this owl is not common, its place being filled by the little screech-owl; but I have found that there are a few in every locality where there is an extensive growth of cedars. They are so sensitive to light that they are never voluntarily abroad at that time of day, and when insecthunting after sunset they make no noise, and might readily pass for a whippoorwill. One that I found by accident in a cedar-tree remained in the neighborhood from October until the following August, so it can fairly be considered as a resident species. 
May it not be that they are really more plentiful than we suppose, especially in pine woods or dense cedar swamps?

The Screech-owl, or Red Owl, or Little Gray Owl, may be said to be semi-domesticated, and it is about the only one that comes to town and makes its home in the larger shade-trees, or the spire of some church that is without a bell. In the country a hole in some apple-tree, or a large cavity that was once a clean-cut woodpecker's nest, is the bird's usual home, and here it remains until dusk, when it comes out clicking its bill with a snap like the cocking of a pistol, and then looking about, mutters the melancholy tu-whoohoo-ho-ho-ho, the ending of it a most doleful quaver.

As to its food, mice of course largely supply that, but this owl has a fancy, too, for squabs, and can clean out a dove-cot if so inclined. But for this it would be as harmless as the Acadian owl or "Sawwhet," as it is sometimes called.

Audubon says of the little red owl, "This little fellow is generally found about farm-houses, orchards, and gardens. It alights on the roof, the fence, or the garden-gate, and utters its mournful ditty." I once knew it to go a little nearer to civilization, and with tragic result. The owl went into the terra-cotta cap of the chimney and on down until it reached a stovepipe hole, and then into the pipe to the crook of an " elbow," and there it rested. Some time after a fire was started in the stove and it "smoked" to some purpose, and the cause was only ascertained by a violent trembling of the pipe and a chattering that would have founded a ghost story years ago. When 
the pipe was taken down, very deliberately emerged a most solemn-looking owl that had had enough of man's contrivance,- - so very much, indeed, that it laid down and died.

The Great Horned or Eagle-owl is found over all of Eastern North America. It is a splendid, stately bird, and when seen perched upon a tall tree, backed by a glowing sunset, is a picture to be remembered. It is essentially a bird of the woods, or at least of remote localities with some heavy growths of timber, and there it proclaims its presence by a loud hoo-hoohoo-hor-hor.

In New Jersey it is principally seen as a winter visitor in the settled portions of the State, but holds its own in the backwoods.

They feed upon small mammals generally, and in winter, when pressed for food, attack the poultry. A word in their favor is that they attack and devour skunks. Strange taste!

The Snowy Owl should be seen alive, and in an evergreen forest, to be fully appreciated. It is then truly a superb bird. This owl is an arctic species, and yet does not require a particularly cold winter to induce it to come very far south of its proper habitat. When they do come in the late autumn southward, they generally follow the sea-coast and do not spread over the back country, but of course there are exceptions, and it was such a case that I witnessed, the birds being on the Delaware River shore, seventy miles from the sea. They are found less frequently in the interior States in winter. In New England their appearance is regular. 


\section{Wilson says, -}

"The usual food of this species is said to be hares, grouse, rabbits, ducks, mice, and even carrion. Unlike most of his tribe, he hunts by day as well as by twilight, and is particularly fond of frequenting the shores and banks of shallow rivers, over the surface of which he slowly sails, or sits on a rock a little raised above the water, watching for fish."

\section{Nuttall draws this pretty pen-picture:}

"His white robe renders him scarcely discernible from the overwhelming snows where he reigns, like the boreal spirit of the storm. His loud, hollow, barking growl,'whowh,'whowh, 'whowh hăh, hăh, $h a ̆ h, h a ̆ h$, and other dismal cries, sound like the unearthly ban of Cerberus; and heard amidst a region of cheerless solitude, his lonely and terrific voice augments rather than relieves the horrors of the scene."

The beautiful Hawk-owl is another arctic bird that but rarely comes even to Southern New England, but which does come even to New Jersey. As the name indicates, the bird is as much a hawk as an owl, a connecting link, as it were, and this has the more significance in that the bird is diurnal.

In the West there occurs in great abundance the Burrowing-owl, or, as Dr. Coues states it,-

"It is the only bird of its family inhabiting, in any numbers, the entirely treeless regions of the West, and may be considered characteristic of the plains. Wherever it can find shelter in the holes of such animals as wolves, foxes, and badgers, and especially of the various species of marmot squirrels, there it is found in abundance, and in not a few instances small colonies are observed living apart from their ordinary associates in holes apparently dug by themselves."

J. K. Lord, in his "Naturalist in British Columbia," remarks, - 
"Living near the water, but occasionally wandering amongst the grass, are quantities of brilliant green snakes, the green racer. . . . Not only does it bask on the grassy banks, or if frightened glide through the herbage with arrow-like rapidity, but climbs trees with the ease and rapidity of a squirrel. In pursuit of tree-frogs, its favorite food, the snakes so nearly resemble green succulent branches that I have often put my hand on them when hirds'-nesting or seeking for insects. It always startled me, though I constantly took them in my hand as I should a plant or a caterpillar for examination. This snake's general residence is in the hole of a ground-squirrel, which is also chosen as a nesting-place by the Western burrowing-owl.

"I dug out several squirrel-holes whilst at this camp; in one I found two eggs of the burrowing-owl, the female owl, a racer-snake, and an old lady-squirrel. The burrowing-owl is strictly of diurnal habits, and feeds principally on crickets, grasshoppers, large beetles, and larvæ. I do not think it ever captures small animals or birds; a peaceful, harmless bird, with little to boast of in appearance, voice, or wisdom."

The Pygmy-owl is the smallest of the race, and found only on the Pacific coast. Lord's account is, in part, as follows :

"Their flight-short, quick, and jerking, similar to that of the sparrow-hawk-is quite unlike the muffled, noiseless flap of the nightowl, as it sails along over marsh and meadow in pursuit of mice, lizards, or any benighted rodent that has incautiously strayed from its place of safety. The food of this little owl is entirely insectivorous, its favorite morsel a fat grasshopper or field-cricket : not that it by any means refuses or objects to breakfast on an early riser, be it beetle or butterfly. . . .

"When in pursuit of food the owls perch on a small branch near the ground, sit bolt upright in an indolent, drowsy manner until their quick eye detects an insect moving on the plain; then they pounce suddenly upon it, hold it down with their small but powerful claws, and with their sharp beaks tear the captive to pieces. . . H Hunger satiated, they return to their tree, and, cuddling lovingly together, sit and doze away their time, protected from the blazing rays of the mid-day sun by the foliage of the sturdy oak. . . . 
"Early in May two small eggs were laid,-a large knot-hole in the branch of the oak being selected as the nesting-place. . . .

"The Indians, without exception, hold this little owl in terrible dread. To see one in the day or to hear its feeble cry, not unlike a stifled scream, is a fatal omen to brave or squaw; the hearer or near relative is sure to die ere the end of the moon. To kill one is an unpardonable heresy." 


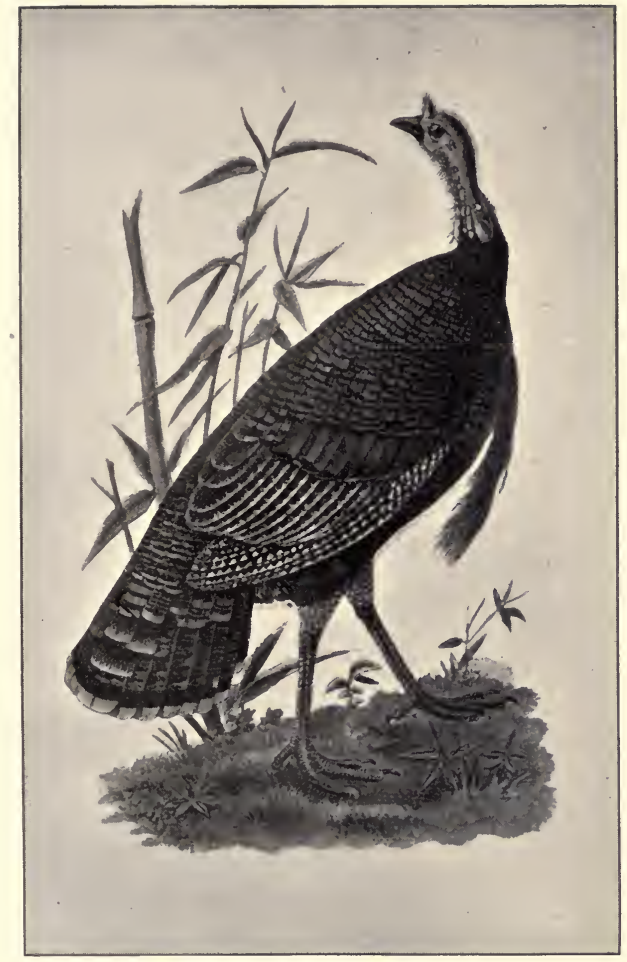

WILD TURKEY. 



\section{CHAPTER IX.}

\section{GAME-BIRDS AND PIGEONS.}

RY "Game-birds" is meant those that are popularly known as Grouse, Quails, Partridges, Ptarmigan, and the Wild Turkey. Of these so-called gallinaceous birds we have a considerable variety, and but for the greed of sportsmen, want of conscience of pot-shooters, and asininity of legislators, would have scattered over the whole country a vastly greater number of individual birds; for we hear the cry of late from every quarter, "Game is getting scarce." Nevertheless, everybody chases the last bird to death, saying, "If I didn't, some one else would."

In the extreme South and Southwest there are a few doves and pigeons peculiar to those regions; but in the United States generally there are but the Wild Pigeon and Turtle-dove, and the former is pretty nearly blotted out of existence.

The common Eastern Quail, or Bob-white, is to all a familiar bird. It probably has not a single habit not thoroughly well known. It is a resident bird, except when nesting, gregarious, and if not harassed beyond all endurance would be quite tame and familiar. It appears to know that at certain seasons it is free from molestation, and comes out into the 
road, dusts itself in the lane, and, perching on a fencepost, whistles the two short, clear notes that have given it one of the many common names by which we know it. When the brood is young it is so well cared for that we do not often see either parents or offspring; but in autumn, when the young are strong of wing, a greater caution comes upon them all, and they endeavor to keep quite clear of man. They are not equal to it, and suffer in consequence, being chased by dogs and hunters until their life must be a veritable burden; but in winter, when the deep snows have come, these same quails come without hesitation to the farm-yard and ask a portion of the poultry's daily meal. They are tame again, and, being so, are very entertaining.

The Mountain-partridge, or Quail of California, is " much the largest and handsomest of this country. Its distribution is limited and rather peculiar, as it inhabits almost exclusively the mountain ranges of Oregon and California." This bird in a general way has the habits of the Eastern bird.

There are several others in the Southwest, their habits varying only so much as the country calls for. They are reported as affording good sport, and what persecution they suffer in that direction now will be as nothing to what is in store for them when the now sparsely-settled region is more generally occupied. The Pacific slope and the Western plains beyond the Mississippi are the homes of the grouse of this country. It is true that we have one species still here in the East, and formerly had two, and that there are ptarmigan in Canada and Northern New 
England, but not until we get far westward of all this region do the grouse become a really prominent feature of the avi-fauna.

The Dusky Grouse is one of these Western forms. Dr. Lord says of it,-

"It arrives at Vancouver Island, at Nesqually, and along the banks of the Fraser River about the end of March and beginning of April. The male bird, on its first arrival, sits on the summit of a tall pinetree or on a rock, announcing his arrival by a kind of love-song,-a sort of booming noise repeated at short intervals, and so deceptive that I have often stood under the tree where the bird was perched and imagined the sound some distance away: It is extremely diffcult to see this bird when you know it is in the tree, so much does it resemble a knob or the end of a dead branch. Soon after their arrival they pair, but during the whole nesting-time the male continues the booming noise."

The Canada Grouse, as its name implies, is a northern bird that ranges more beyond our boundaries than within them, but is found in "the timber districts in Northern New England." They are a bird of the pine and spruce woods, and on products of this vegetation they are said largely to feed.

The Ruffed Grouse, which in the Middle States is usually called the "Pheasant," may be said to be "the survivors of a once numerous tribe," as we speak of Indians; for certainly, common as this bird still is, it is as nothing compared to half a century ago, and judging from references in old manuscripts presumably to this bird, they at one time or at the settlement of the country were extremely abundant. "Their drumming in the woods would sound often as if every hive of bees was swarming."

Wilson says of this bird,- 
"Its favorite places of resort are high mountains covered with the balsam pine, hemlock, and such like evergreens. Unlike the Pinnated Grouse, it always prefers the woods; is seldom or never found in open plains; but loves the pine-sheltered declivities of mountains near streams of water. This great difference of disposition in two species, whose food seems to be nearly the same, is very extraordinary. In those open plains called the Barrens of Kentucky the Pinnated Grouse was seen in great numbers, but none of the Ruffed; while in the high groves with which that singular tract of country is interspersed the latter, or Pheasant, was frequently met with, but not a single individual of the former.

"The native haunts of the Pheasant being a cold, high, mountainous, and woody country, it is natural to expect that as we descend thence to the sea-shores, and the low, flat, and warm climate of the Southern States, these birds should become more rare, and such indeed is the case. In the lower parts of Carolina, Georgia, and Florida they are very seldom observed, but as we advance inland to the mountains they again make their appearance. In the lower parts of New Jersey we indeed occasionally meet with them, but this is owing to the more northerly situation of the country, for even here they are far less numerous than among the mountains. . . .

"The manners of the Pheasant are solitary; they are seldom found in coveys of more than four or five together, and more usually in pairs or singly. They leave their sequestered baunts in the woods early in the morning, and seek the path or road to pick up gravel and glean among the droppings of the horses. In travelling among the mountains that bound the Susquehanna, I was always able to furnish myself with an abundant supply of these birds every morning without leaving the path. If the weather be foggy or lowering, they are sure to be seen in such situations. They generally move along with great stateliness, their broad fan-like tail spread out. . . ."

The ruffed grouse in what may be called "ancient history" is more interesting than the present humdrum life it is forced to lead. In the woods and swamps of Central New Jersey these birds used to congregate in winter by the thousands. As they were rare in summer, it was supposed (and rightly) 
that they came down from the mountains a few miles up the river and above tide-water. It was, in the closing years of the last century, a common sport, indulged in by all on the farms, to surround these birds, and when "a great host were gathered in a few trees, to fire at a given signal." The old flint-locks, loaded with bits of nails and cut pieces of sheet-lead, seem now to be poor weapons indeed, but they wrought fearful havoc, and the representatives from different farms would go home each laden with a "big mess of pa'tridges." In those days, too, they were netted in open places in the woods, and every man who went into the woods to cut firewood or fence-rails took a gun with him, and usually brought home some of these birds. A century has brought about wonderful changes in the bird-world, and while we are engaged in contemplating what is, and sometimes regretting the absence of what was, we seem never willing to consider what will be. It is a great mistake. The pheasant would still be found even in our smallest bits of swamp and woodland, even away from the mountains, if given a chance.

To stock a locality in May and kill every bird in November, as is done with quails, does not promise much for the future.

"Ptarmigan may be said to be simply Grouse which turn white in winter. They are the only members of this family of birds in which such a remarkable seasonal change of plumage occurs. All the Ptarmigans are Grouse of boreal or alpine distribution, only reaching sea-level in the higher latitudes, elsewhere confined to mountains." -Cours.

"The Willow Ptarmigan ranges through boreal 
America from Labrador to Alaska." This bird and the Rock Ptarmigan, which appears to be more a dweller of the open country than the preceding, feed on berries and other products of the scanty herbage of the far north, and even eat lichens, which they find by burrowing in the snow.

\section{Nuttall states,-}

"These birds search out their food chiefly in the morning and evening, and in the middle of the day are observed sometimes to bask in the sun. Like the Eskimo, . . . whose lot is cast in the same cold and dreary region, they seek protection from the extreme severity of the climate by dwelling in the snow; it is here they commonly roost and work out subterraneous paths."

These birds are not the only ones that work out subnivean passages to reach their food. The late Dr. Lockwood has given us an excellent account of the manner in which the little snow-birds cleared away the snow and got at the berries of poke-weed; and even used "their snow dug-out . . . as a cozy asylum from the cutting wind by day."

The Prairie-chicken, or Pinnated Grouse, has been too long and too well known to need further description. This is a bird of the prairies, and was supposed to have been found all the way eastward to the Atlantic coast, Nuttall speaking of their occurrence on the grouse plains of New Jersey. These plains, or the "barrens," are now innocent of anything like a grouse; but on Martha's Vineyard the Heath-hen is still living and, it is said, carefully preserved. It is said to be a bird of open woods rather than open country and to feed upon acorns. The heath-hen was not uncommon in New Jersey in colonial days, and was 
not exterminated until within the past fifty years, a few remaining in the "barrens," or grouse plains, as Nuttall called them.

The Cock of the Plains is thus described by Dr. J. K. Lord:

“These grouse live entirely on the open sandy plains, their principal food being the wild-sage, which imparts such a rank, unpleasant flavor to the flesh that one might almost as well chew the bitter bush as eat any part of a sage-cock. It is almost impossible to obtain the cocks in full nuptial costume, when their necks are fringed with the most delicate pinnated feathers. The meeting of two cocks is sure to result in a fight, during which the greater part of these ornamental feathers are usually torn out. Unless the birds are killed prior to a hostile encounter, their plumage is never perfect, as they only have these fine neck and back plumes at mating-time.

"It is impossible for any one to avoid being at once impressed with the extraordinary adaptation of the sage-cock's color to the localities in which he lives; the mottlings of brown, black, yellow, and white are so exactly like the lichens covering the rocks, the stalks of the wild-sage, and the dried leaves, bunch-grass, and dead twigs scattered over the sandy wastes, that it is impossible to make them out to be birds when they crouch close to the ground. Their greatest enemies are eagles and large falcons, which, ever soaring over the plains or perching on some lofty rock-pinnacle, scan the far distance for any moving objects on which to pounce. The poor sage-cocks have no shelter; not a tree or shrub save the pungent sand-plant is there to hide them; but their marvellous coloration compensates for lack of other protection, deceiving even the sharpeyed birds of prey."

"The Sharp-tailed Grouse," according to the same author, " is alike estimable, whether we consider him in reference to his field qualities, or viewed as a table dainty, when bowled over and grilled. Though his flesh is brown, yet for delicacy of flavor I'll back him against any other bird in the Western wilds. . . . Its favorite haunt is on open grassy plains, -in the morning keeping itself concealed in the thick, long grass, but coming in about mid-day to the streams to drink and dust itself in the sandy banks; it seldom goes into the timber. 
and if it does, always remains close to the prairie, never retiring into the depths of the forest.

"They lay their eggs on the open prairie in a tuft of grass or by the foot of a small hillock, nesting early in the spring, and laying from twelve to fourteen eggs. . . . They first appear in coveys or broods about the middle of August. . . . About the middle of September and on into October they begin to pack; first two or three coveys get together, then flock joins flock, until they gradually accumulate into hundreds. On the first appearance of snow they begin to perch, settling on high, dead pine-trees, the dead branches being a favorite locality."

The Wild Turkey, that in the seventeenth century was common and in the eighteenth abundant, has in this nineteenth been exterminated over the greater portion of its original range. West of the Mississippi it is yet found, but as we approach the Rocky Mountain region another species takes its place. Dr. Warren reports that it is still found in Pennsylvania, but at scattered points, and they will soon be rooted out even from them. He says also, that people have expressed to him the view that some of the so-called wild turkeys are domestic birds that have wandered off and become "as wild and cunning as the typical Meleagris gallopavo which in former years was abundant." There is excellent reason for believing that this is quite true, for it is well known that the birds are both given to wandering and to great cunning in concealing their nests and eggs.

Of the pigeons and doves of the United States, the Passenger-pigeon of the country eastward, and well remembered by many people, is the most interesting; but comparing what we read with what we see nowadays, it is quite evident that this bird, like the turkey, 
will soon be a matter of history. In many localities, especially along our Atlantic seaboard tier of States, the bird is now quite unknown where fifty years ago it annually made its appearance. In enormous numbers these pigeons would come, remain a few days, and pass on. The

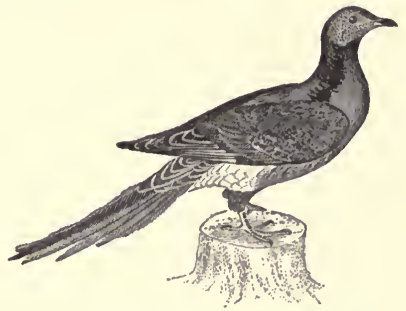

Wild Pigeon.

graphic account given by Audubon, that was ridiculed so by European naturalists, is true to the letter. In November, I 865, I saw a flock that must have contained three or four thousand birds. This was in Monroe County, Pennsylvania. Since then I have seldom seen even single birds. Dr. Warren reports them as scattered about the State, but nowhere in great numbers. They will soon disappear from this section, and the same will happen in the West. They are captured there by "netting," and the opinion has been expressed, and with good reason, that "the pigeon will soon join the buffalo on that list so disgraceful to humanity, 'the extinct' species, -a list that will be filled rapidly if a check is not put on men's avarice and the law's shameful negligence." (Chamberlain.)

The following is from Wheaton's "Birds of Ohio:"

"Mr. Read states that in the spring of 1851 they appeared ' in vast numbers in the fields, feeding upon the dead grasshoppers, the 
remains of the countless hordes which well-nigh devoured "every green thing" during the preceding summer and fall,' a statement which will surprise ornithologists who have been accustomed to consider birds of this family as exclusively vegetarian."

The Turtle-dove is everywhere well known. In the Middle States it is both resident and migratory, and while shy and keeping much out of sight, is nevertheless not a rare bird nor one difficult to find if you take the trouble to look it up. At certain seasons they are often seen in public roads dusting themselves, and I have known them to build their nests very near to dwellings; but for all this, they are a bird of the out-of-the-way nooks and corners of the farms, and keep pretty close to the woods the greater part of the time. Their flight-power is very good, and when you startle them they speed away with a whistling of the wings that is as characteristic as the $a^{\prime}-k \circ \bar{o}-k \circ \bar{o}-k \circ o$ that we hear all day long from April until the end of summer.

Doves are not, like the wild pigeon, gregarious, and yet we sometimes see a great many in a very short space of time; but however abundant, it is always a close association of individuals that move quite independently. They do not seem to "flock" like blackbirds.

This dove is found as far west as Arizona, and Dr. Coues states that it there builds its nest sometimes in such thorny bushes that it seemed impossible the bird should itself escape injury. This was to protect itself and young against reptiles of many kinds. Even in such a benighted region the doves are very abundant. 
"The Ground-dove is a native of North and South Carolina, Georgia, the new State of Louisiana, Florida, and the islands of the West Indies. In the latter it is frequently kept in cages, is esteemed excellent for the table, and honored by the French planters with the name of Ortolan. They are numerous in the sea islands on the coast of Carolina and Georgia; fly in flocks or coveys of fifteen or twenty; seldom visit the woods, preferring open fields and plantations; are almost constantly on the ground, and when disturbed fly to a short distance and again alight. They have a frequent jetting motion with the tail ; feed on rice, various seeds, and berries."-WiLson. 


\section{CHAPTER X.}

THE SHORE BIRDS.

WHILE, in considering the habits of the many birds to which we have referred, we have been as much about the wet meadows as the dry fields, and along the river-shore as in the upland woods, nevertheless, the birds that have been brought to notice were essentially land birds with the exception of the kingfisher, which we can only think of as associated with the quiet mill-pond or some little creek where the silvery minnows flash in the ripples. But there are birds that can only exist by the water, or at least depend upon it for their food-supply. Every land bird can live on the river-shore or near the ocean, but not all "shore birds" can wander from the watery wastes, or exchange the dusky avenues of a forest for the swamps, the marsh, the treacherous quicksands, and the banks of the river.

The shore birds of the United States are divided into six groups or families, some of very few and others of many species, making sixty-five in all. The greater number of these are birds of the sea-shore, some seldom leaving it, and others only at certain seasons, when they follow up the main watercourses for long distances, and, leaving them, pass to the shores of our most insignificant creeks. But these 
instances are comparatively few, and it is only where there are large bodies of water that shore birds generally are likely to be found. Unless large, these birds are not conspicuous, and while nearly all have pleasant, piping notes, they cannot be considered as musical. To the world at large they are of interest as excellent eating; if not that, they are ignored. They are extremely entertaining, however, to the naturalist, and whoever is fond of seeing the birds that Nature has designed for certain localities in those localities, will regret that many such are yearly becoming less abundant. This is particularly true of many "shore birds," and what Turnbull, in his beautiful volume on "Birds of East Pennsylvania," has said of "Birds which have disappeared" will bear repeating.

"Since the eastern provinces have become more densely popnlated many of the larger and more wary species of birds have changed their course of migration, and now reach the arctic regions by a route taking them towards the interior of the continent; and there are also some formerly known as summer visitants which have now a more southern limit. Parrots, for example, are at the present day [this was written in 1868] rarely found north of the Carolinas; while Wild Turkeys, which were once abundant, although still to be met with in suitable localities, are now in very limited numbers. In a rare tract printed in 1648, entitled 'A Description of New Albion,' - a name at one time applied to this part of the country, -we read of four or five hundred Turkeys forming a single flock. The Pinnated Grouse is another interesting bird which has become nearly extinct [quite so now] in East Pennsylvania, and entirely so, it is believed, in New Jersey. The Whooping Crane may also be said to have disappeared, not even a straggler having been seen for some years. It likewise seems to have been once very plentiful, for we read in Hakluyt's 'Voyages,' ed. 1589, fol. 729, that Captain Philip Amadas and his fellow-adventurers, who visited and explored the coast in 1584, 
' having discharged their harquebus-shot, such a flock of Cranes (the most part white) arose, with such a crye, redoubled by many ecchoes, as if an armie of men had showted together.' The Brown or Sandhill Crane has not been seen in this region for many years past, although it is still not uncommon in the West. The learned Professor Kalm, who travelled in this country in $1748-49$, and resided some time at Swedesborough, New Jersey, noticed this bird on its northern flight about the middle of February. At that time they usually alighted, but remained for a short time only, every spring, in comparatively limited numbers; but he was assured by a colonist, above ninety years of age, that in his youth (or about the year 1670 ) Cranes came in hundreds. The Rough-billed Pelican was also frequent on the Hudson and the Delaware, but is now a very rare visitant to the last-mentioned river only.

"While ornithologists, however, have to deplore the diminution in the number of the more conspicuous birds which has taken place during the last century, it is gratifying to find a very sensible increase in the number of other species. Many of the Warblers, for example, then considered rare, are now found to be abundant, $-\mathrm{a}$ beneficial increase, for which we are no doubt indebted to the fact of our efficient game-laws providing for the protection of insectivorous birds. But, on the other hand, the constant shooting of 'Bay Snipe' and shore birds generally by market gunners, always on the watch for their arrival, has seriously reduced the flocks of many species formerly known to abound in districts now but thinly peopled by this interesting class. The late Mr. George Ord assured the writer that, during his excursions to the coast with Wilson, the distinguished ornithologist, the Avocet, Stilt, and other Waders which are becoming rare in our day were then quite plentiful, so that there is every reason to fear that in the course of a few years more they also may disappear.

"In Chesapeake Bay, the winter resort of a great variety of wild fowl, birds, although still numerous, are, through the same influences, becoming every year less abundant, and unless the present reprehensible and most destructive system of shooting-wholesale slaughter it may with propriety be called-be rigidly put down [it since has been], the decrease will, in all likelihood, become permanent, to the great regret of every true-minded naturalist. We have but to look into the history of some of the birds of the British Islands as a warning against the continuance of the destroying influences to which many of those of our own country are now subjected. Dur- 
ing the past thirty years the Rapacious Birds of Great Britain have undergone an amount of persecution so determined and systematic that many of the species have altogether disappeared; and as by the latest records of the meetings of the British Association assembled at Norwich, it would appear that even sea-fowl are now in danger of extirpation [they are now protected], owing to the extraordinary demand for their plumes and feathers for marketable purposes, it may not be out of place for the ornithologists of this great continent to consider the propriety of protecting, even now, some of the species thus proclaiming by their scarcity that the time may not be far distant when we, too, may have to lament their loss."

The Phalaropes, or "Coot-footed Snipe," as I have heard them called, are represented by three species, all occasionally seen, but nowhere abundant, except on the sea-coast at intervals. These curious birds look like sand-pipers, but do not act like them. They are swimmers rather than waders, and when seen at a little distance are remarkably duck-like. They are all migratory, and in the Middle States and New England are seen in spring and autumn, generally at the latter season. They appear on our inland waters as well as along the coast, and doubtless many a specimen is shot and goes the way of all game-birds, the naturalists of the neighborhood not suspecting that such a bird was about. I have twice seen examples of two of the species on the counter of a game dealer in Philadelphia, and I have seen the Red Phalarope several times on the Delaware River, more than one hundred miles from the ocean.

The red phalarope breeds in the highest northern regions, and is said to have an unusual method of conducting the preliminary courtship: the female captures a mate, and after the eggs are laid lets him 
attend to the monotonous matter of hatching them. It is significant that the female is somewhat larger and a finer-feathered fowl. In other words, the sexes are badly mixed, the female laying the eggs, but the male being the real mother. Such things have been known in unfeathered bipeds.

Wilson's Phalarope is not a northern bird in the sense that the others are, as it breeds in the United States. It is not uncommon westward from the Mississippi Valley, but rare in the Atlantic seaboard States. Warren reports it, however, in Pennsylvania, saying that "at Erie Bay small flocks of these phalaropes are sometimes to be seen in the fall swimming in the water like ducks."

The Lobe-foot, as this bird is known to many, is stated by Dr. Cooper, in his work on the ornithology of the Pacific seaboard, to pass "in spring and fall through Washington Territory [now State] in small flocks, which associate sometimes with the sandpipers, but appear to prefer wetter feeding-grounds, wading in the shallow creeks at low tide, and even swimming on the ocean several miles off shore." This is equally applicable to our Eastern phalaropes as seen in March off shore and on the beaches of New Jersey.

In the United States there are two beautiful wading birds that have considerable in common and yet are not even generically related. These birds are the Avocets and the Stilts. The Avocet is one of our largest wading birds, and is beautifully marked, being largely black and white. The upward curve of the bill at once distinguishes it from other waders. They were formerly very abundant on the New Jersey 
coast at certain seasons, but are far less so at the present time. They are not mentioned by Warren as a bird of Pennsylvania, yet specimens have been killed on the shores of the Delaware within the boundaries of that State.

While a strictly shore bird in the Middle States, they are very abundant on the Western plains and in the States bordering on the Mississippi. Dr. Coues has given an excellent account of them as seen in the far West.

The Stilt, or Black-necked Stilt, is another curious bird, in that its legs seem rather too long for the bird's comfort, but they have never appeared to be a real hinderance, and, as has been stated, "as waders they are a great success." At present they are much more abundant in the West-the far West-than along our Atlantic seaboard, except in Florida. This was probably not true of the bird originally, for the gradual disappearance only commenced about the beginning of the present century.

Of these birds, Dr. Coues remarks as follows:

"Avocets and Stilts correspond with each other in habits as closely as they do in form. One of the most marked physical differences is found in the structure of the feet. Avocets have a hind toe, which the Stilts have not, and their feet are almost completely webbed, so that they are among the best swimmers of the long-legged fraternity. Stilts, on the contrary, scarcely swim at all, and never except on an emergency. When the Avocets are wading about, it often happens that they get beyond their depth, when, instead of rising on wing, they keep on as if nothing had happened to take them off their feet."

The Woodcock is so highly prized as a dainty morsel, and is so persistently pursued in season by 
the sportsman, that the natural history of the bird is very well known. In the Middle States it comes

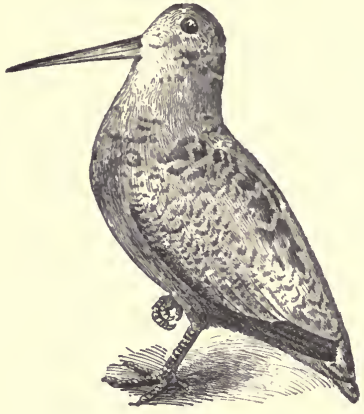

Woodcock. usually in February if the weather is mild, and in March if the spring is backward, and knowing the country pretty well, if an old bird, locates about some bubbling spring around which the ground is soft and warm, and where the sun shines for a good part of the day. There are always such places in every county, and the bird can thrive very well even if there are a good many cold snaps after its arrival. Quite early it has got through with its peculiar courtship, and the eggs placed upon the bare ground are a matter of great care to both parents.

Nuttall's account of the courtship is as follows :

"During the mating season, in the morning as well as evening, but more particularly the latter, the male in the vicinity of his mate and nest rises successively in a spiral course like a Lark. While ascending he utters a hurried and feeble warble, but in descending the tones increase as he approaches towards the ground, and then becoming loud and sweet, pass into an agreeable, quick, and tumultuous song. As soon as the performer descends the sound ceases for a moment, when with a sort of stifled utterance, accompanied by a stiff and balancing motion of the body, the word blaik, and sometimes paip, paip, is uttered." 
The Snipe, Gray Snipe, English Snipe, and Wilson's Snipe, as it is variously called, is another familiar migratory bird that is common to our marshy meadows, both a short distance inland from the ocean and across the continent. It breeds in the northern regions, as a rule; but to assert that it does not remain south of New England and breed is absurd. There was never a summer, I think, that these birds were not seen on the Delaware meadows after the annual spring flight had gone north, and I have found them breeding or with young birds on more than one occasion. Warren gives instances of its being found in summer in Pennsylvania. It may be true that the majority of such over. staying birds are

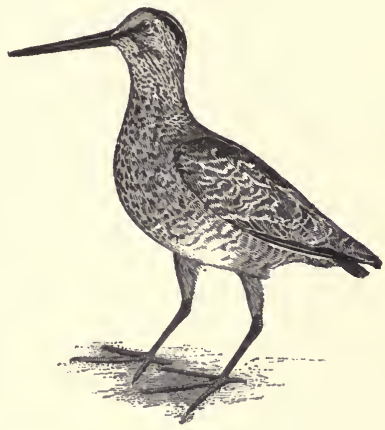

English Snipe. "crippled;" but, injured or sound, they rear their young all the same, and twenty years ago I suggested that such wounded birds had brought into existence birds that were content on their northward migration to themselves nest in the locality where they were born.

The Dowitcher, or Robin Snipe, is a sea-coast or . salt-marsh bird that comes in the spring, goes north to breed, and returns in early autumn. They do not 
wander far inland in the Middle States, but in the interior of the continent, along our large rivers, they are abundant in the early autumn or late summer southward migration.

The true Sand-pipers are all most interesting birds, and as so many of them are common to our inland streams and one is almost a land bird, they are pretty generally known. Along our river-shores particularly these birds congregate in large numbers, and in August, when all nesting duties are over, to see a troop of "tell-tales" or "yellow-legs" running over the muddy flats at low tide and hear their mellow whistling, as they take wing and go speeding off to other watery wastes, is a pleasant experience to him who loves a rational outing, - an outing not merely for muscular exercise, but for mental. To realize what bird-life is we must do a great deal more than merely collect the creatures and measure to the thousandth of an inch their hind toes. It is necessary to see the bird in life, and this phase of bird-life, where we have the animal on land yet forever in the water so far as length of limb will permit, is one of the most entertaining. But it is not only along the river-shore that we find the sandpipers. There is a dainty spotted one that is at home even among the upland fields, and is as content with a tiny brook as where the water is miles in width. It is a bird, too, of our mill-ponds, and its cheery peet-weet is as certain a sign of the coming of warm weather when we first hear it as is that of any bird of the field or forest. With few exceptions, the sandpipers are strictly migratory and breed in the far 
north. Their breeding habits probably are much the same, and what the birds do at such times and in that region has best been described by Seebohm in his classic little volumes, "Siberia in Europe" and "Siberia in Asia." In the tundras he found the sandpipers nesting, and scattered through the pleasant pages of these charming books we get glimpses of the life of these birds, that, so far as we know them at home, are visitors only.

Many of these sand-pipers that are fairly common to our sea-coast marshes are birds of the interior. Dr. Warren records them as occurring at Erie Bay in Pennsylvania, and in the far West many are very abundant; much more so, indeed, than in our Eastern districts.

Of the inland species, the Spotted Sand-piper, known so generally as the "Teeter-Tiltup," from its quaint way of bobbing both head and tail as it walks, deserves especial mention.

Wilson's account is as follows :

"This very common species arrives in Pennsylvania about the twentieth of April, making its first appearance along the shores of our large rivers, and, as the season advances, tracing the courses of our creeks and streams towards the interior. Along the rivers Schuylkill and Delaware and their tributary waters they are in great abundance during the summer. This species is as remarkable for perpetually wagging the tail as some others are for nodding the head; for whether running on the ground, or on the fences, along the rails, or in the water, this motion seems continual; even the young, as soon as they are freed from the shell, run about constantly wagging the tail. About the middle of May they resort to the adioining cornfields to breed."

This sand-piper is the only one that ventures quite 
within the limits of our villages. I have seen it along roadsides very often, but never so tame as in a village in Monroe County, Pennsylvania, where it followed a little creek that passed through the place, and ran under a simple bridge and was not disturbed by passing teams. It would leave the water and skurry over the dusty wagon-tracks, dodging the horses as do the English sparrows, and when induced to fly, only moved a few yards away.

The Solitary Sand-piper, a little larger and darkercolored bird than the preceding, is another species that leaves what might be considered its proper haunts and comes very close to civilization. The name "solitary" is not altogether a well-chosen one. These birds appear in spring, and we often see a considerable number of them together. They are then usually about the wet meadows, and have a decided fancy for newly-ploughed fields where water lies in

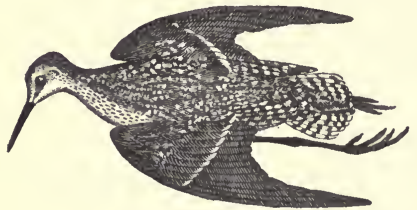

Solitary Sand-piper. the furrows; and again, it is nothing unusual for one to be surprised in or very near a barn-yard, hunting for insects in the very black, fetid, and repulsive pools. I have often been surprised at the actions of these birds when startled and forced to leave a spot to which they have been attracted. With a flirt of their slender wings they dart off, and gradually rise to an immense height and sometimes 


wholly disappear. I have known two, three, and four minutes to elapse, and then, like lightning from a clear sky, the bird would suddenly reappear, touching the ground lightly with its dainty feet and raising its wings straight up above its back, as if to celebrate the victory of having escaped and returned in safety. Again and again I have flushed the poor solitary, and it invariably flew two or three miles, I judge, before returning.

There has been from time to time some discussion of the habits of this bird so far as its breeding is concerned. Speaking for the Delaware River Valley, I can say that while the bird is migratory and might by casual observers be considered as generally so, a few do remain within the limits of Pennsylvania and New Jersey during the summer. I have seen them during the months of June and July in both the States mentioned, and I found a pair once in great distress because an enormous bull-frog had swallowed their newly-born young. It is foolish for theoretical ornithologists to dispute such statements. There is no possibility of any one mistaking this bird for any other, and as I have known the two species well and for many years, it borders on the ridiculous to suggest that the two-the spotted and the solitary-were confounded.

A beautiful upland and dry-ground sand-piper is well known to many as the Grass Plover,-an unfortunate name, as it is not a true plover,-and it is also called Bartram's Tattler. "It inhabits at different seasons nearly all of North America, and in winter pushes its migration even to Central and South 
America." In the Middle States it is both migratory and resident. Dr. Warren records, as observations of this bird in Pennsylvania,-

"This species resides during the breeding season in grass-fields and highlands. . . . O Often in the summer these birds alight on fences along the roadside, in trees, etc., and raise their long wings to their full extent. When breeding these birds are found singly or in pairs, and they are then quite unsuspicious, often allowing a very near approach before they take to wing or run off and hide in the grass, but in the late summer when assembled in flocks they become exceedingly shy and difficult of approach. ... Its ordinary note is a rather loud, yet soft and pleasing-whistle, but when breeding it frequently utters a loud, prolonged, and tremulous piercing scream, which, when heard at considerable distance, sounds very much like the sudden cry of a child in great distress."

It is in August that flocks of these birds are scattered over the country, and of late so very shy are they that we can hear their mellow whistle but cannot see the birds. They are early birds, too, and before sunrise will scour a field for food and be up and off before the cows are turned into the pasture. I had often noticed the whistling birds overhead, but never could find them except in the air, and now I know the reason. This bird is not as abundant in Eastern Pennsylvania and New Jersey as in Wilson's day.

George Ord's note to Wilson's account is as follows :

" Bartram's Sand-piper is known to our shooters by the name of Grass Plover. It breeds in low grounds, in the State of New Jersey. When watching its nest it is fond of sitting upon fences, and on alighting it throws up its wings in the manner of the Willet. In the early part of August it begins to migrate; it then flies high, and may be easily recognized by its whistling notes, which resemble those of 
the Tell-tale. In the middle of June I observed this species in the vicinity of Burlington, New Jersey, but I could not discover its nest."

With the birds of the vicinity of Burlington I am very familiar, and I have never found the nest of this bird there; but I am confident that it breeds in the highlands of Bucks County, Pennsylvania, on the opposite side of the Delaware River.

In April and again in late July, and from then until the weather cools, there are two pretty little sandpipers that make for me the sandy ocean-shore exceedingly attractive; these are the Least and Semipalmated "Peeps," as they are so generally called. The Least Sand-piper is the more abundant of the two, and comes with more regularity along our rivers, especially in autumn; but they are best seen running on the beaches of old ocean, following the receding wave and never being overwhelmed by the incoming deluge. Flush them and the cheery "peep" sounds loud and clear above the roar of the ocean, and with what confidence they speed over the troubled water, almost venturing to touch it with their toes as it rushes madly beneath them! This is one of the many sights in the bird-world that I never tire of.

The true Plovers, of which there are many kinds, are an interesting family, and coming within the scope of sportsmen's game-birds, are well known to people who measure a bird only by the toothsome qualities of its flesh. To some people, however, a whistling quail is as dear a song-bird as is the melancholy thrush or exultant grosbeak.

The larger forms, as the Black-bellied and Golden Plover, are migratory birds that nest well up in the 
arctic circle, and return southward in August, when they are objects of much interest to the sportsman. The first named keep principally along the sea-coast, and are rare in the far West. Occasionally they appear in fields in our river valleys, and then may be readily mistaken for the Golden Plover, as their movements and flight are quite alike. Its voice, however, is more shrill and chattering than that of the other large plover, which, known generally as the "Bull-head," appears pretty regularly in the Middle States about September I, and remains for three or four weeks. Occasionally a large flock will settle in a field and remain for several days, or until the gunners find them out, which usually is soon after their arrival, for their whistle is only too well known, and they have not learned the wisdom of keeping quiet. When feeding they appear to have sentinels posted about, for the alarm-cry is sure to be heard as you approach, and it requires a great deal of patience to get within gunshot, - that is, when these birds have come inland. On the immediate sea-coast they are watchful, but not as difficult to approach.

The Semi-palmated Plover is a smaller, strictly migratory form that nests north of the United States.

There are found in the Middle States in summer, especially on the sea-coast, and at times along our rivers, two beautiful little plovers, known as the "Piping" and "Wilson's." The former reaches us about April, and in flocks of a few individuals run about the sand on the sea-shore in a most lively manner and utter a variety of cries that are all more or less pleasing, blending as they do with the roar 
of the ocean. When this sound, coming from the throats of many plovers, is heard after dark, it is particularly striking, as wild and weird as the whistling of the wind through the rigging of a ship at sea.

This little plover nests on our sea-coast, and makes most violent demonstrations and pleads piteously when the eggs are approached. I found them nesting in the meadows back of Holly Beach, on the New Jersey coast, in June, 1893.

In August many scores of these birds come up the Delaware River as far as tide-water extends, feeding on the gravel-bars and mud-flats at low tide, and occasionally following up the courses of the creeks until they find themselves well into the country.

Wilson's Plover is less common, but not at all rare on the Southern New Jersey coast, and, like the piping, comes up our rivers, and when there is quite the same in habits as the preceding. It is not unusual to find on one sand-bar these two plovers, the sanderling, and a few "peeps." They run in and out among the little hills and hollows in the mud, each uttering its own cry, and together filling the air with a pleasant piping and twittering that is, as a whole, musical. Flush them and they will get up as one flock, but before they have gone far will separate and keep apart until the cause of alarm has gone, when they reassemble, and as one happy family pursue their insect-hunting, each after its own fashion, but all without a trace of quarrelling. The little minnows that are often left in pools at low tide are eaten by all these little plover. 
The genuine, or literally "upland," plover is the familiar "Killdeer." It is migratory, but it makes a long stay with us in the Middle States. It sometimes comes by the middle of February, and is said to be always fol-

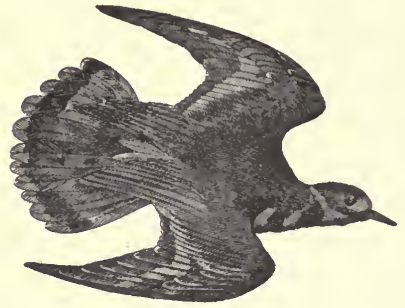

Killdeer. lowed by the snipe. Not always immediately followed, however. We first find the killdeer along the river, and if the ground, upland, is frozen, they will remain there; but very soon they come to their old haunts in the dry fields, and add a great deal of life to what is apt to be a rather commonplace locality. They find in time a safe spot, as they think, to lay their eggs, and then are all anxiety for fear some one will step on them. If you come near they make a great ado and imitate lameness to perfection, but you cannot pick them up, for all that.

\section{Wilson says,-}

"Nothing can exceed the alarm and anxiety of these birds during the breeding season. Their cries of killdeer, killdeer, as they winnow the air overhead, dive and course around you, or run along the ground counterfeiting lameness, are shrill and incessant. The moment they see a person approach they fly or run to attack him with their harassing clamor, continuing it over so wide an extent of ground that they puzzle the pursuer as to the particular spot where the nest or young are concealed, very much resembling in this respect the Lapwing of Europe. During the evening and long after 


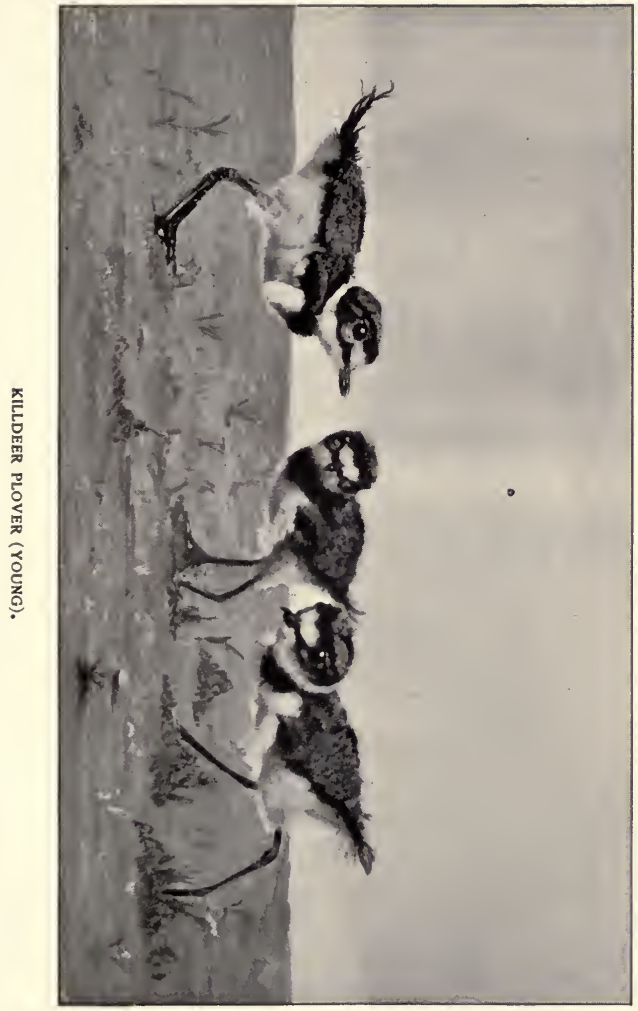



dusk, particularly in moonlight, their cries are frequently heard with equal violence, both in the spring and fall. From this circumstance, and their flying about both after dusk and before dawn, it appears probable that they see better at such times than most of their tribe. They are known to feed much on worms, and many of these rise to the surface during the night. The prowling of Owls may also alarm their fears for their young at those hours; but whatever may be the cause, the facts are so."

The Turnstone is a marine bird, a dweller on the sea-coast, and when found inland may be looked upon as a mere straggler; literally a storm-tossed bird; for it is well known that sea-birds have been driven many miles inland when the coastwise storm has been of unusual violence. In spring and autumn they are moderately common. They breed in the arctic regions.

"This bird is naturally of a wild and solitary disposition, coursing along the shore by pairs or in small families which have been bred together. The Turnstone, while flying, often utters a loud twittering note, and runs at times with its wings lowered, but is less swift in its movements than most of the Sand-pipers, and more patient and intent in obtaining its fare. Like the Woodpeckers, it is content to search over the same place for a considerable length of time; the mechanism of its bill seems well provided for this purpose, and it is often seen in this way turning over stones and pebbles from side to side in search of various worms and insects."-NUTTALl.

It is said that they make entertaining pets, and thrive very well under what must be very changed conditions for them.

The Oyster-catcher, which Turnbull says, in his "Birds of East Pennsylvania," is also called the "Flood-gull," is recorded as "rather scarce." It certainly varies in respect to numbers from year to year, and probably in the Middle States has perma- 
nently ceased to be other than a rare bird. There are few people to be met with now along shore who can recall these birds as occurring in any considerable numbers, although they profess to know them. Nuttall's statement of their being "common" in New Jersey is no longer applicable. 


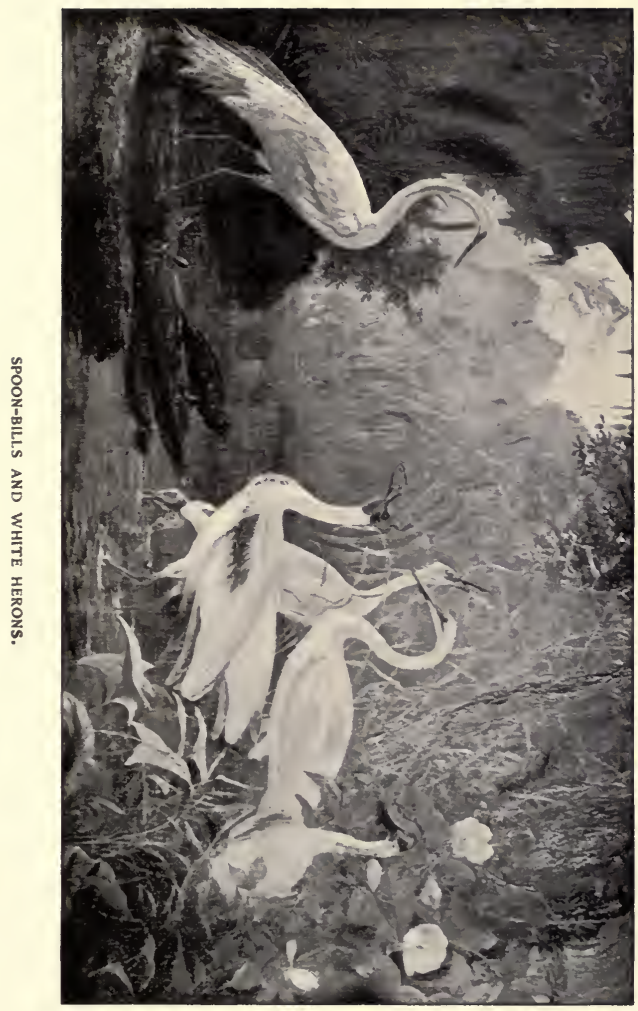





\section{CHAPTER XI.}

HERONS, RAILS, ETC.

IT was as far back as 185 I or 1852 that I overheard the remark that there was a freshet on the meadows and many strange birds about. My curiosity was excited, for I had been taken to the meadows and seen them under all their summer aspects. But what of this wide reach of lowlands now with a "freshet" on them? It had recently been raining, that I knew; but the fields were dry and all about seemed just as usual, but fresher after the continuous downpour that for three days had kept me housebound. I was beginning to feel abundant self-confidence, and longed to be in some measure my own master. I asked no questions, but early in the morning stole off to the wonderful meadows. As I approached I saw no change, but directly after perceived that familiar pastures were glittering with water. I kept upon the higher ground and followed a path leading to the creek. It was all so strange, and in the brilliant sunshine of a June morning every bird seemed unnaturally large and sang with an earnestness that almost startled me. The bushes hid the creek at every point, and I drew them aside that I might stand alone on the bank where in time past 
I had been brought as a great treat. How exciting it was to be alone! I had no thought of fear, and knew, of course, nothing of my danger. As I pushed aside the branches of low bushes and peeped through at the wide creek with its high, overhanging elms on either bank, I saw a huge bird that was taller than myself. It uttered a loud cry, and, spreading its wide wings, flew to the other shore. How I stared at the wonderful sight! and there, in full view, were others of these great birds, some blue, some white, and all birds bigger than myself. Were these birds the "freshet" of which I had heard? Hour after hour I stood there, looking as I have never since looked at birds; looked and wondered, and never knew that the water was slowly rising, inch by inch, until I stood in it ankle-deep. Then it was, and there on the creek-bank, I was found by anxious searchers, and slowly made to understand that I had been snatched from the grave. That was more than forty years ago, and to this day I am willing to stand ankle-deep in water to watch the stately herons come and go whenever there is a freshet on the meadows.

The large and stately birds that are known as herons, ibises, the spoon-bill, and egrets, are not confined to the Southern States, and a feature only of impenetrable forests. They come, except the spoonbill and flamingo, every spring well up into the Middle States and northward to New England; and some of them find the sheltered springs and open waters of New Jersey and Pennsylvania sufficiently hospitable even in winter, and so make the more attractive those rather desolate places. But the day 
of their abundant presence is forever over. The disgraceful persecution to which for some years they have been subjected, and the indifference of the general public, has caused their numbers to be so greatly lessened that some of the larger species are well-nigh exterminated. What were common birds in their season, half a century ago, are now rarely seen; and those that were tame, permitting a near approach, are now so exceedingly shy that we can only get the most unsatisfactory glimpses. It is often the case that we must be content with the view of herons "flying over," and never, apparently, settling anywhere.

It was a habit, too, at one time of herons to nest and roost in communities; these "heronries" being a not unusual feature where there was a growth of heavy timber not far from water. The herons now are wise enough to build singly, and locate their nests in the most secluded places. The struggle for existence has been a violent one and the herons have been worsted. Scarcely a word of protest has been heard, and none that has proved effectual. Heron plumes became fashionable and the birds were doomed.

This class of birds are, one and all, absolutely harmless and unfit for food, although occasionally some of them are eaten. There is not the slightest excuse for killing them, any more than an excuse could be offered for shooting a swallow. There is no need now for ornithologists to collect additional specimens: that plea for collecting is worn threadbare. Their anatomy and habits are thoroughly known, 
and all needed information can be had from scores of books.

Naturally, the whole tribe of herons are disposed to be sociable, and as willing to frequent a mill-pond as the retired and wooded banks of far-off rivers. All they ask is not to be disturbed. The nightherons have been known to lodge in trees in a large town, and this uncommon occurrence might be a common one but for the positively brutal indifference of the average man, who will pernit these inoffensive and beautiful birds to be shot at, even if he does not indulge in the sport (?) himself. There should be an almost prohibitive tax on the modern breechloader. I have seen a man deliberately shoot at an overflying heron, just to see if his gun would carry that far. Fortunately, it did not. If I had tried my gun on him in the same way, there would have been a great rumpus; but the bird, of the two creatures, was much the more valuable.

It is not improbable that our blue, white, and nightherons and the bittern would all become as familiar as the storks are in Europe if they had the same immunity from persecution granted to the fish-hawk. I say this, because experimentation in a slight way has gone far to demonstrate it; and it is well known that birds learn very quickly where they are free from annoyance and where subjected to it. The migratory birds that nest in a locality with comfort during one season will be pretty sure to return the next; but rob them of their eggs or young and they will give the place a wide berth thereafter.

In some respects the Roseate Spoon-bill is the 


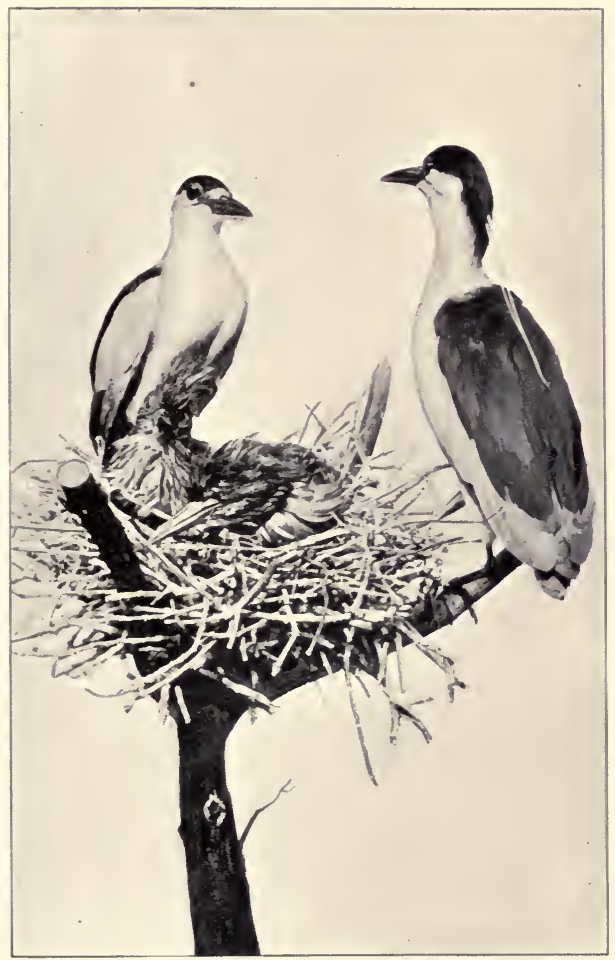

NIGHT-HERONS AND NEST. 

most remarkable of all our birds of this class. Its common name accurately describes and readily distinguishes the bird from the herons or ibises. It is roseate, not a uniform red like the Scarlet Ibis, and the bill is flattened and rounded at the end. The time was, and not long ago, that the spoon-bills were moderately abundant in Florida and along the seaboard of the Gulf States. Now they are rare. Chamberlain says "the plume-hunters have almost exterminated them there" (in Florida).

Spoon-bills are nocturnal in habit; act generally as the herons; are gregarious and shy, posting a sentinel when feeding.

Including the above, there are some twenty of these long-legged and long-necked birds, and their habits are very much alike wherever we find them. Some are migratory, and yet are not particularly sensitive to a low temperature, as individual birds winter as far north as the Middle States.

The Scarlet Ibis is now scarcely a bird of the United States, but the White Ibis remains, and is a splendid bird. It is strictly a Southern species, that wanders irregularly northward along the Atlantic coast, even as far as New Jersey, and farther inland up the Mississippi Valley. Nuttall quotes Bartram to the effect that the ibises "fly in large flocks or squadrons, evening and morning, to and from their feedingplaces or roosts, and are usually called Spanish Curlews. They subsist principally on crayfish, whose cells they probe, and with their strong pinching bills drag them out."

Nuttall adds, "Sometimes, according to Bartram, 
during the prevalence of high winds and in thunderstorms, they may be seen collected into numerous flocks, driving to and fro, or turning and tacking about high in the air, during which evolutions with the contending currents of the wind their silvery plumage gleams and sparkles with unusual brilliance as it reflects the flashing light from amidst the dark and hovering clouds." This superb sight was noted by Bartram in the eighteenth century, but few have seen it in the present one, and the bird will be a matter of "ancient" history before long.

The Glossy Ibis, so well known the world over, is not a common bird anywhere in the United States, and only a "visitor" north of Florida. The following is taken from Bonaparte's very full account of these birds, as he had observed them both in Europe and in this country:

"Let it come whence it may, the Glossy Ibis is only an occasional visitant of the United States, appearing in small flocks during the spring season, at very irregular periods, on the coast of the Middle States. The specimen Mr. Ord described, and which produced a strong sensation even among experienced gunners and the oldest inhabitants as a novelty, was shot on the seventh of May, 1817, at Great Egg Harbor, and we have seen others from the same locality and obtained at the same season, as also from Maryland and Virginia. A beautiful specimen, preserved in the American Museum at New York, was shot a few miles from that city in June, 1828. . . United States specimens that have come under my observation were all adults. During their stay among us they occupy places near marshes and grounds subject to be overflowed, where there are no trees, but abundance of grass and plenty of their favorite food. They search for this collected in flocks of from thirty to forty, and explore the ground with great regularity, advancing in an extended line, but closely side by side. When they wish to leave one side of the meadow for another, they do not take wing, but walk to the 
selected spot. When they have alighted on a newly-discovered rich spot of ground, they may be observed on it for hours, continually boring the mud with their bill. They never start and run rapidly like the Curlew and Sand-piper, but always walk with poised and measured steps, so that Elian says the Ibis's motions can only be compared to those of a delicate virgin. The body is kept almost horizontal, the neck much bent, like the letter $\mathrm{S}$, and lifting their feet high. If alarmed, or when about to depart, they rise to wonderful heights, ascending first in an inclined but straight flight, and then describing a wide spiral, the whole flock are heard to cry out in a loud tone, their voice resembling that of geese; finally, having reached what they consider the proper height. taking a horizontal direction, they soon disappear from the sight. Their flight is vigorous and elevated, their pectoral muscles being very thick; they fly with the neck and legs extended horizontally, like most Waders, and as they float along, send forth from time to time a low and very hoarse sound. Their food consists chiefly of small aquatic testaceous mollusca, and they do not disdain such small worms and insects as they may meet with. They are supposed to live chiefly on leeches (whence their Tuscan name Mignattajo), but erroneously, none of these having ever been found in their stomachs either by Prof. Savi or myself."

The Wood Ibis is asserted not to be common "anywhere within our borders," but Dr. Coues says that it is abundant about Fort Yuma, and he has given a most entertaining account of the bird in his "Birds of the Northwest ;" but Fort Yuma, it may be said, in passing, is very much otherwise than in the Northwest, and is so thoroughly tropical as to have the thermometer run up to $115^{\circ}$ in the shade. Florida, on the Atlantic seaboard, is its proper home, and as a straggler we get an occasional glimpse of one even in New Jersey. Dr. Warren mentions several instances of its occurrence in Pennsylvania.

In our common Bittern we have in New England and the Middle States a moderately well known bird, but one that, by reason of its retiring habits and 
rather nocturnal ways, is better known by name than by personal observation. Still, the bittern is not difficult to approach, and when it gains a little confidence, or has its young to look after, may be seen to advantage if you are not too demonstrative. Why is it, by the way, that women are never content with observing a sitting bird? Even if it is a thrush in the middle of his song, the chances are she will scream and "shoo!" Queer things. The bittern in the Middle States is both resident and migratory. It builds a nest of sticks and grass, the sticks being the foundation, in the marsh, where the bird lives the greater part of the time; and if you pass by at mid-day, the chances are you will not know that such a bird is anywhere near you. If you do flush it, you see a pair of brown wings lazily flapped, see an awkward neck thrust out ahead and a pair of long legs that almost dangle. You hear a kwok, very like the gag preliminary to vomiting, and then, settled to work, a graceful flight, if the bird intends to go any distance. I remember one bittern that spent the summer on my meadows that invariably, when flushed, flew to the hill-side near by, a distance of about seven hundred yards, and alighted on the same tree always. When I passed by, and was nowhere near the nest in the marsh, the bird would promptly return. This bittern, from March to November, remained, I think, daily in the one small tract of marshy meadow.

At night the bittern makes a most curious sound, which has been described as "booming." I was always of opinion that the sound was made while the bird had its beak in water, but it seems not, and 
when I have seen a bird in this position I have heard another "booming." The sound is made by forcing the air from its crop through the throat, and is expelled with a curious noise that sounds like $a m$-băh when heard at a distance, but has a different sound and a not readily described one when you hear it near by. Indeed, the sound is not a uniform one, and even varies at times with the same bird. This "booming" is kept up until pretty late, but is very rarely heard except after sundown. I have never heard it in the winter.

Of all our water-birds, I have always had the strongest liking for the Least Bittern. It is beautiful, gentle, readily tamed, and has when in its own haunts a quiet, winning way about it that is captivating. They are abundant every year in a tract of marshy meadows along the Delaware, and there are not at all shy. It has a habit, that I have often noticed, of walking out into the open meadow and picking up grasshoppers with a dexterity that is very marked, and when apparently no longer hungry, it throws its head back and rests it between its wings so that the beak is pointed directly upward. Is this to aid digestion? The position is maintained but for a minute or two, and then the bird runs off to the marsh and is out of sight. When startled, the bird will often raise its wings and give perhaps half a dozen strokes, and then drop again into the weeds; but the discharge of a gun near will rouse all its energy, and the bird will dart off with rapidly vibrating wings and sometimes pursuing an erratic snipe-like course. Except when disturbed, it is a silent bird, but utters 
an alarm-cry that is a heron-like quä, but not louder, usually, than the cry of a snipe.

The nest is a mere shallow saucer of dead reeds and grass, and the eggs are of a greenish-white color that is so much like the surrounding sickly, halfbleached vegetation at the surface of a marsh that they are quite inconspicuous. The bird, when sitting, is not readily disturbed, and if it thinks you don't see it, will let you pass by without any movement on its part. Such, at least, has been my experience. Chamberlain mentions " a cooing note . . . that is low, soft, and sweet," uttered during the nesting season. This I may have heard, but never associated with these bitterns.

These birds, which come to New Jersey about April I 5, do not remain, like the preceding, and spend a winter about a warm, bubbling spring, - that is, do not do so voluntarily, but occasionally one has been found out of season. Such birds were doubtless in some way disabled, for it is hard at times to distinguish them from the king-rails that are so common in the same marshes, and many are killed every year, and necessarily some are slightly wounded. Such birds would not migrate or attempt it, and may possibly be able to survive an "open" winter. In the height of " reed and rail" shooting the least bittern will often, when flushed, take refuge in a tree and assume a very unbird-like attitude, so that it is not readily seen unless you follow the bird in its flight. Its colors blend well with the surroundings, and, as a whole, the bird bears a good deal of resemblance to a broken branch. 
Of the true herons there are several species in the United States, of which in the New England and Middle States the Great and Little Blue Herons are the best known. The former is a migratory species and also resident. In New Jersey and Eastern Pennsylvania there is annually a considerable number of these birds from April to October, but during the winter the number is small. When they come, in early spring, and have no shelter, they are very shy, and seem much more intent upon guarding against surprise than upon securing food. At times they will appear in the level, open meadows, and fish in the ditches, but never wander near to any bushes or clump of trees in which some foe may,be lurking. Later, when the foliage is out and there is "cover" in the larger trees, these birds will sit in them by the hour motionless and silent, but at dusk they will fly abroad and utter a hoarse cry at brief intervals. Still, they are in no sense nocturnal, and can be found food-hunting at all hours of the day. This food consists of anything in the way of an animal that can be swallowed, an exception probably being young turtles. I have known one of these great blue herons to swallow nearly every one of a large school of catfish. Frogs, of course, are eagerly snapped up, and meadow-mice, crayfish, and even coleopterous larvæ are not overlooked. One that I had in captivity demonstrated how strictly omnivorous they are so far as regards a meat diet.

The Little Blue Heron is in most of its habits the same as the preceding, with a tendency to remain quiet in the daytime. They come in small numbers 
as far north as New Jersey, and are more common along the coast than inland.

The American Egret and the Snowy Heron, to the casual observer, might be thought to be the same birds as the preceding two, but white instead of blue. When the four species are together, as I have seen them, feeding in flooded meadows, they have a very marked similarity in all their movements. They walk gracefully, carry themselves in a stately manner, and when flying are the embodiment of grace. They float easily rather than laboriously fly.

“ Unfortunately, and to man's or woman's discredit, very few of these birds are now to be seen: they have been slaughtered for their plumes." This, written of one species, is applicable to all. This is the sad state of affairs in Florida, and in the Middle States it is even worse. Practically, all our heronries are deserted. It was the habit of these birds to build in colonies, and in the space of an acre of woodland would be a great number of nests. Now, when the herons breed the nest is in some most solitary place, and there will not be another pair of birds within several miles. In many respects the herons are no longer interesting. A single bird or a single pair have become a matter of curiosity, but the "troops" that added so much to the landscape years ago have gone from us forever.

It may not be long before we are reduced to the little "Fly-up-the-Creek" as the sole representative of the herons, and even these little fellows are in some danger, as I have heard of their being eaten. This bird, which is the Green Heron, and nicknamed 


$$
d
$$



more than all other birds put together, is migratory. It is first seen in the Middle States about April I, and winter has fairly set in before it retires to a more congenial clime. As a general thing they have escaped serious molestation, and in many localities are very tame. I have often walked within ten steps of them without their being alarmed, and more often have had them come very near to me when I was sitting on a ditch-bank watching the aquatic life before me. I have known them to walk to the very door of a spring-house, on the watch for minnows, and pay little attention to the milkmaid, when she appeared. A little brook with fish and frogs, a few trees near by for a "heronry," and these little fellows are happy. Gain their confidence, as you readily can, and they will prove a constant source of amusement, and, better than that, if there can be somethin's better, they will help in keeping down the grasshoppers; and if they are not equal to swallowing a meadowmouse, they can and will chase him out of the pasture.

The nest of this little heron is but a mere matter of a few loosely-laid sticks, and the four or five eggs are in constant danger of tumbling to the ground, and this untoward fate does sometimes befall the young birds.

The Night-heron, which is known so generally as the "Quok," a name derived from the bird's ordinary cry when flying, is in some respects a more interesting bird than any other of the family. It is still abundant and, not being extremely timid, is readily observed. As its name implies, it is nocturnal, and yet it is by no means blind in broad day. 
light. It is both migratory and resident in the Middle States, but the number that remain during the winter is comparatively small, and these overstaying birds are rather forlorn creatures if the weather is very cold. As they sit huddled together loosely wrapped in their feathers, with shoulders up and heads down and their bills quite out of sight, they might readily be mistaken for inanimate objects were it not that they have a very keen sense of hearing and move if you come very near the trees in which they are resting. That they appreciate warmth is shown by the fact that in winter these birds will feed at noon when the warm springs have a flood of noontide sunshine resting over them, and will stay at home during the night, this being reversed in moderate winter weather and during the summer.

Early in May, in days gone by, these birds collected by hundreds at the heronries and nest building commenced; now single nests are usually found, although we often see ten or more birds togther about their feeding-grounds. In 1860 there was an enormous heronry near the Delaware River, where a large creek enters it in Burlington County, New Jersey. This was disturbed and the birds so harassed by boys stealing the eggs that early in the summer the spot was suddenly and entirely deserted, and since then, in that vicinity, the birds that still come year after year build their nests far apart, and seem in all their nesting habits to have instituted a complete change.

The night-heron feeds principally upon fish, but has also a fancy for salamanders, for I have twice seen them on a wooded hill-side near the springs, 
rummaging among the dead leaves, and I can imagine no other reason for their doing so, unless it was to catch the little black salamanders that were there and at that time extremely abundant. Again, in confinement, these birds seem to prefer the batrachian to fish.

The Yellow-crowned Night-heron is a southern species that very seldom wanders as far north as the Middle States. I have seen it on the Delaware meadows as far up the river as the limit of tidewater.

Of true Cranes we have three species, of which, as we have seen, two were once seen on the Atlantic coast as far north as New Jersey. Peter Kalm, writing from New Jersey under date of February 17, 1749, says, -

"Cranes were sometimes seen flying in the daytime to the northward. They commonly stop here early in spring for a short time, but they do not make their nests here, for they proceed on more to the north. Certain old Swedes told me that in their younger years, as the country was not yet much cultivated, an incredible number of cranes were here every spring, but at present (1749) they are not so numerous. Several people who have settled here eat their flesh when they can shoot them. They are said to do no harm to corn or the like."

As given by Ridgway, the present range of the Whooping-crane is as follows: "Interior of North America, north to the Saskatchewan, south to Florida and Central Mexico."

This crane is said to be of "the most imposing appearance of any [bird] of this country." It is more than four feet in length, and when seen on the open prairie is often mistaken for quite different objects than birds of any kind. Dr. Coues, in "Birds of the 
Northwest," gives amusing instances of mistakes of this kind.

The Brown or Sandhill Crane is a little smaller bird, and slate-gray varying to brown, instead of pure white, like the preceding. Except in Florida, not found east of the Mississippi River. Mr. Dall found these cranes breeding in Alaska on the Yukon River, the eggs "laid in a small depression on the sandy beach, without any attempt at a nest."

The following from Wilson, while purporting to be an account of the whooping-crane, applies also to the sandhill crane, which he appears to have considered the young of the former. This account is of interest now more particularly, because it is descriptive of a phase of bird-life on the Atlantic coast of New Jersey now forever passed away.

"This is the tallest and most stately species of all the feathered tribes of the United States; the watchful inhabitant of extensive saltmarshes, desolate swamps, and open morasses in the neighborhood of the sea. Its migrations are regular and of the most extensive kind, reaching from the shores and inundated tracts of South America to the arctic circle. In these immense periodical journeys they pass at such a prodigious height in the air as to be seldom observed. They have, however, their resting stages on the route to and from their usual breeding-places, the regions of the north. A few sometimes make their appearance in the marshes of Cape May in December, particularly on and near Egg Island, where they are known by the name of Storks. The younger birds are easily distinguished from the rest by the brownness of their plumage. Some linger in these marshes the whole winter, setting out north about the time the ice breaks up. During their stay they wander along the marsh and muddy flats of the sea-shore in search of marine worms, sailing occasionally from place to place, with a low and heavy flight, a little above the surface, and have at such times a very formidable appearance. At times they utter a loud, clear, and piercing cry, which may be 
heard at the distance of two miles. They have also various modu. lations of this singular note, from the peculiarity of which they derive their name. When wounded, they attack the gunner or his dog with great resolution, and have been known to drive their sharp and formidable bill at one stroke through a man's hand."

The march of civilization has not made such sad inroads upon the rails and gallinules as upon the herons and birds after their kind. The low growths of the marshes are too rank to be successfully searched by the omnipresent gunners, and a vast number of birds that are with us in season escape the dangers to which they have been subjected and live to come again. It is to be noted, too, that some attention is paid to the bird's welfare, and during the nesting season they are protected. But laws or no laws, a showy crane or plumed heron has a trivial money value, and is sure to be shot down sooner or later, even if sitting at the time on its nest. Certainly birds, because not fit to eat, should not be overlooked by the law-makers. They have as much right to live as quails or grouse, and besides being useful, have a value in being ornamental, which is something to be considered, but seldom is. There is no unavoidable reason why some birds once common are now rare. It is not man's mere presence that does the mischief, but his fiendish greed and brutal indifference to the welfare of life generally.

In the Clapper-rail of our sea-coast, the Kingrail of the fresh-water marshes, and the Virginia Rail of both localities, we have three well-marked species that are very alike in all respects, the Virginia rail being a small edition of either of the others. Of 
course there are well-marked specific differences, but the resemblances are very strong, and in their habits the birds seem to vary only as their respective localities render necessary.

The rank growth of rush-like grass upon the lowlying flats near the sea-coast affords a moderately secure home for the clapper-rail from April until cold weather drives them southward. They do not go much north of New Jersey, but there they are really very abundant, although the number is decreasing in consequence of the reckless destruction of their nests, thousands of eggs being gathered. These birds announce their coming by a quaint cackle that, when uttered by hundreds at once, as sometimes happens, sounds like the spring-tide rattling of innumerable frogs.

The King-rail is a rarer bird, found only in freshwater marshes, and is found in pairs or singly, rather than in colonies; yet it sometimes happens that more than one pair will occupy a very limited bit of marsh. In a marshy tract of about three acres in extent I have yearly, for just twenty years, found a pair of king-rails, and usually find their nest. Unlike the salt-water birds, they do not cackle continuously, but when excited utter a kek-kek-kek that tells you the bird is near, but you cannot accurately locate the sound. It varies from a high key to a low one so rapidly that you get the impression there are a number of birds immediately about you.

They are hard to flush, preferring to run rather than take wing. They nest in the tall grasses, and the young leave the nest and run through the grass when 


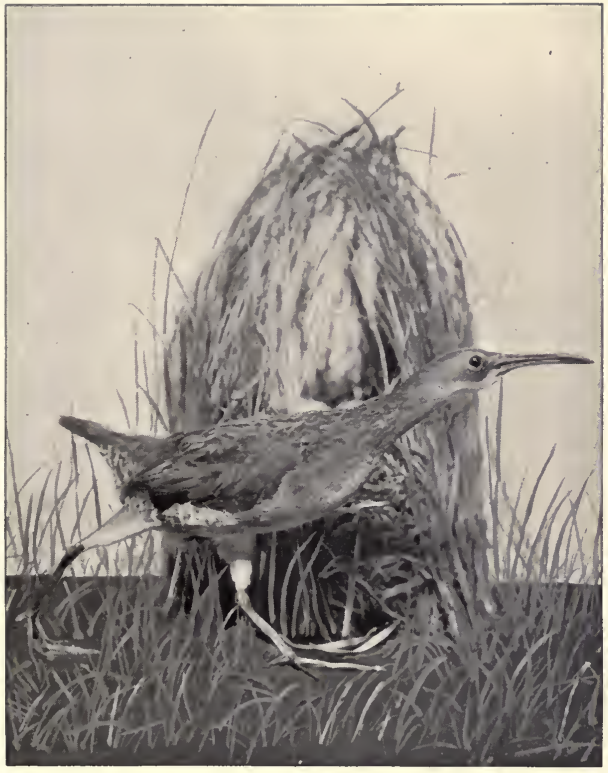

CLAPPER-RALL AND NEST. 

very young, and being of a uniform dark-gray color, look not unlike meadow-mice when in motion.

In August these birds, both old and young, extend their wanderings to the river-shore and associate to some extent with the smaller rail-birds. They are excellent swimmers, and to some extent crepuscular in habit, as I have found them occasionally in the "open" meadows after sunset and on bright moonlit nights.

The Virginia Rail, which is a very much smaller bird than the preceding, does not differ in its habits at all. It comes to the Middle States about the same time, frequents the same localities, and leaves at about the same time in autumn. They are more abundant, however, wander farther from the larger watercourses, and nest in swampy sink-holes and about quicksand meadows where there are numerous springs. They are quicker on their feet than on their wings, and can literally walk on water,-that is, on floating grass that would not bear their weight as a lifeless body. This running over the water is partly accomplished by a quick motion of the wings which is scarcely noticeable.

In August and September great numbers of these rail-birds leave their more retired nesting-places and throng the tide-water marshes, where, associated with the soras, they run the gauntlet of a thousand gunners; but so numerous are they that their ranks are never so depleted that a year's rest and nesting does not restore their numbers.

The Sora is, in the knowledge of most people, the rail. The others are birds either never seen or heard of, or chance occurrences, but everybody is sup- 
posed to know the little rail as well as the chipping sparrows in the garden; better, in fact, for they are a common bird upon the table when in season. This bird comes to the Middle States in May and goes on northward, breeding in the New England States as a rule, but Dr. Warren states that it nests in various parts of the State (Pennsylvania). In the early summer the habits of this rail-bird are precisely those of the other species, and the clicking sound they make not unlike that of the king-rail, but not so loud. Late in July these birds begin to congregate on the marshes of our larger rivers, and where there is an abundant food-supply there the rails will gather in hundreds. It is no uncommon occurrence for two men, one pushing the boat and the other shooting, to bag one hundred of these birds in a day. Their flight at this time of the year is so slow that the bird when it rises presents an easy mark; but when it is satisfied to run rather than fly, it is difficult for a spaniel to overtake it.

In every marsh, particularly towards the close of summer, besides the various species mentioned, will be found a few little Yellow-breasted Rails. They offer in habits no peculiarities; and in the same localities where these birds occur are found two rail-like birds that present a rather striking appearance as seen standing on the edge of a little pool, or running a few steps before taking wing. These birds are the Gallinules. There are two, known as the Purple and Florida Gallinules, and as seen stalking along the grassy shore of some retired pond or quiet reach of river-shore, the two birds look very much alike. 
They are migratory, but both occur throughout the United States except on the Pacific coast. The Florida gallinule is much the more common of the two. In the valley of the Delaware they are rather shy, especially when nesting, but in August, like the king-rails, are apt to be noisy when excited or alarmed. Their utterances at this time are a good deal like the imitative sounds made by the yellow-breasted chat. One reason, perhaps, why these birds are not more generally known is that they keep very much in the background during the day, and are active in the early evening. This trait led me to consider these gallinules rare on the upper tide-water meadows of the Delaware; but I learned recently that in fact they were not uncommon, and one of them nested every year in the swamps some distance back from the river valley. Dr. Warren considers the purple gallinule as extremely rare in Pennsylvania, and the latter, the Florida gallinule, as uncommon. This may be true of the interior of the State, but not of the Delaware Valley and of Southern New Jersey. The Florida gallinule nested on the shore of the millpond in Bristol, Pennsylvania, in the early summer of $\mathrm{I} 893$, and is a familiar bird to all the gunners of that neighborhood.

The common Coot is so seldom seen, except swimming on our ponds and inland creeks, and, of course, the rivers, that to most people it is much more like a duck than a rail-bird, and is known very widely as the "Crow-duck," about as absurd a name as could well be imagined.

The coot is migratory in the Middle and New 
England States, and yet the time they are absent from the Middle States is quite short, for they are seen early in April and often late in November. In September, or perhaps mid-August, the coot begins to become common in the Delaware Valley, and many

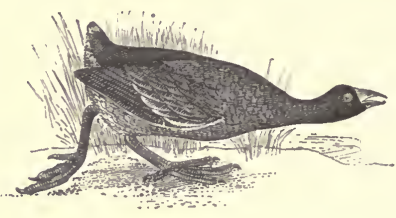

Coot. tarry through our Indian summer in November, if we have one; but they do not all desert the Middle States in the early spring. They breed on Crosswicks Creek, in Burlington County, New Jersey, and have done so for years ; and during the past summer (I 893) I observed a pair on the Delaware River in the early part of July, and saw others in the first few days of August. The nest of the coot is made of reeds and placed among them, being safely secured to the growing stems, but not, as has been stated, so fixed that it rose and fell with the tide.

Coots, as I have observed them in New Jersey, are both diurnal and nocturnal, always prefer deep water, frequent mill-ponds, are not shy, and do not leave the water except by flight, or very rarely. Occasionally they wander up ditches leading into the creeks, and so get farther inland than usual. If surprised, they dive and swim down the ditch with incredible velocity, and soon find their way into the open water. As an article of food coots are absolutely worthless. 


\section{CHAPTER XII.}

DUCKS, GEESE, AND SWANS.

THE birds mentioned in the heading of this chapter are familiar to all, as they are represented by domesticated forms and are not restricted to any particular locality, the Swans being less common than the others, because ornamental rather than useful. Geese, Ducks, and Swans as "wild fowl," however, are vastly different from their tamed representatives. The latter have lost all their charm, unless the stateliness of the swan be worthy of exception; but these birds seen on the broad waters of the Chesapeake, or far north, in their breeding haunts, are in all things the superiors of their subdued cousins of the public parks.

Ducks, Geese, and Swans are represented in North America by fifty-three species, there being three swans (one only in Greenland), two treeducks (only found in Mexico and in limited districts adjoining that country's northern boundary), seven or eight geese, and the rest true ducks. The greater number of these birds are widely scattered, and are a prominent feature not only of our sea-coast at certain seasons, but follow up all our watercourses and reach the interior of our country pretty thoroughly. Strong of wing, mere distance has no significance 
for them. The flock of ducks that sports about the river here to-day may to-morrow be hundreds of miles away. This tremendous power of flight makes migration scarcely a task, and as a result the greater number of wild fowl breed in the far north. Were it not for this, the list of recently extinct species would soon be swelled to a very significant extent. As it is, the numbers of many species have materially decreased and one, at least, has disappeared.

Under date of November 9, I748, Peter Kalm, a Swedish naturalist then staying in Southern New Jersey, wrote,-

"All the old Swedes and Englishmen born in America, whom I ever questioned, asserted that there were not near so many birds fit for eating at present as there used to be when they were children, and that their decrease was visible. They even said that they had heard their fathers complain of this, in whose childhood the bays, rivers, and brooks were quite covered with all sorts of water-fowl, such as wild geese, ducks, and the like. But at present there is sometimes not a single bird upon them; about sixty or seventy years ago, a single person could kill eighty ducks in a morning, but at present you frequently wait in vain for a single one. A Swede above ninety years old assured me that he had in his youth killed twentythree ducks at a shot. This good luck nobody is likely to have at present, as you are forced to ramble about for a whole day without getting a sight of more than three or four. . . . The wild Turkeys, and the birds which the Swedes in this country call Partridges and Hazel-hens, were in whole flocks in the woods. But at this time a person is tired with walking before he can start a single bird.

"The cause of this diminution is not difficult to find. Before the arrival of the Europeans the country was uncultivated and full of great forests. The few Indians that lived here seldom disturbed the birds. They carried on no trade among themselves, iron and gunpowder were unknown to them. One-hundredth part of the fowl which at that time were so plentiful here would have sufficed to feed 
the few inhabitants; and considering that they cuitivated their small maize-fields, caught fish, hunted stags, beavers, bears, wild cattle, and other animals whose flesh was delicious to them, it will soon appear how little they disturbed the birds. But since the arrival of great crowds of Europeans things are greatly changed : the country is well peopled and the woods are cut down; the people increasing in this country, they have by hunting and shooting in part extirpated the birds, in part scared them away; in spring the people still take both eggs, mothers, and young indifferently, because no regulations are made to the contrary. And if any had been made, the spirit of freedom which prevails in the country would not suffer them to be obeyed. But though eatable birds have been diminished greatly, yet there are others which have rather increased than decreased in number since the arrival of the Europeans."

The practical extermination of wild fowl, especially on inland waters, which long ago was supposed would soon be accomplished, has not yet taken place, and even on rivers where there is much steamboat travel and endless loafing in pleasant weather, and no laws on the subject of fowl-shooting, the ducks and even geese are more abundant to-day than when Kalm wrote one hundred and forty-five years ago. This, however, has no real bearing upon the general statement as made, that our wild fowl are decreasing in numbers, extraordinarily abundant as they are in some localities. Again, they are driven more and more from their old feeding-grounds and congregate in waters so wide and open that approach is extremely difficult. The question of primary importance is, Cannot some check be put to the wholesale slaughter that at many points still goes on? Certainly it is to be hoped so, and the fate that has overtaken the herons be averted from less showy but more valuable birds. 
The two swans that are found in the United States are migratory. The Trumpeter Swan is the Western species, found "chiefly from the Mississippi Valley, and northward, to the Pacific, Hudson's Bay, Canada. Casually on the Atlantic coast. Breeds from Iowa and Dakota northward. In winter, south to the Gulf." (Coues.) As the common descriptive name indicates, these birds have a loud cry or trumpet-call that is even said to be "startling," so strange and unbirdlike is its character. Hearne, Nuttall quotes to the effect that he had heard them "in serene evenings after sunset make a noise not very unlike that of a French horn, but entirely divested of every note that constituted melody." Dr. Newberry, in the "Pacific Railroad Reports" (1857), says,-

"The Trumpeter Swan visits California with its congeners, the Ducks and Geese, in their annual migrations, but, compared with the myriads of other water-birds which congregate at that season in the bays and rivers of the West, it is always rare; . . . frequently, while at Fort Vancouver, their trumpeting drew our attention to the long converging lines of these magnificent birds, so large and so snowy white as they came from their northern nesting-places, and, screaming their delight at the appearance of the broad expanse of water, perhaps their winter home, descended into the Columbia."

The Whistling Swan is the Eastern species, although it winters on the Pacific coast, and it comes trooping southward in October, or later, and passes southward until it reaches the Chesapeake, where many tarry, but many more go farther south. It is only occasionally that a swan is seen on the Delaware, but in Peter Kalm's time and up to I 800 the bird was not uncommon as far north as the tide-water portion of 
the Delaware Valley. Old maps and deeds refer to Swan Point and Swan Island too frequently not to indicate that the names came in use through the one-

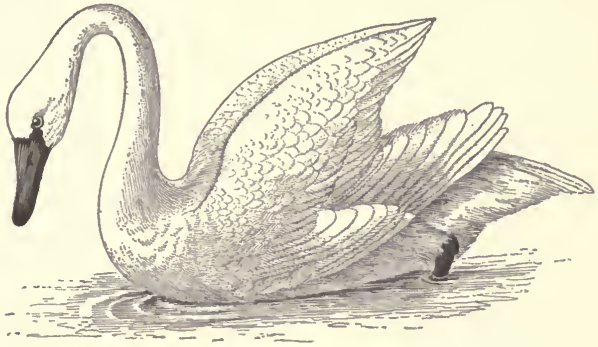

Whistling Swan.

time occurrence of these birds. Dr. Warren speaks of these birds as common at certain seasons on Lake Erie and along the rivers. Steamboats have effectually driven them from the Delaware. According to Mr. Dall, who saw these birds in numbers on the Yukon River, "the eggs are usually in a tussock quite surrounded by water, so that the female must sometimes sit with her feet in the water." The swans when flying utter a shrill note, like phwée-ōo-ōo. You hear the same cry occasionally when the wind screams through ice-coated telegraph-wires.

In the Wild Geese we have birds of a more commonplace character, yet they are very interesting outside of the attractions they possess for the sportsman. There is a wealth of suggestiveness in hearing the "honk" of wild geese in early spring that would 
make the bird very welcome had they no value otherwise, or forever kept beyond the rifle's range.

Of the seven or eight species of geese found in this country, the Canada Goose and Brant on the Atlantic coast and the White-fronted and Snow Goose on the Pacific side are probably the most abundant. These birds all breed in the far north, and enter the United States in autumn and return in spring.

In the more densely settled regions, even where there are no large towns upon our river-banks for many miles, the appearance of geese on our Eastern rivers is not any more a common occurrence. It is true that these birds are killed every autumn by professional gunners, but the flocks that fly over far exceed in number the few that tarry even for a day. Contrary winds and dense fogs sometimes force the migrating geese to stop where they would never voluntarily halt, as in open fields, on mill-ponds, and in the river within sight of town. Such haps on their part generally prove to be mishaps. It is along the seacoast, or in the far West, along the great river valleys, that wild geese are to be seen in their glory, and when followed persistently by the professional gunners, in their misery. Wilson says of the Canada goose, in part, as follows:

"The flight of the Wild Geese is heavy and laborious, generally in a straight line, or in two lines approximating to a point, thus >; in both cases the van is led by an old gander, who every now and then pipes his well-known honk, as if to ask how they come on, and the honk of 'all's well' is generally returned by some of the party. Their course is in a straight line, with the exception of the undulations of their flight. When bewildered in foggy weather they appear 
sometimes to be in great distress, flying about in an irregular manner, and for a considerable time over the same quarter, making a great clamor. On these occasions should they approach the earth and alight, which they sometimes do to rest and re-collect themselves, the only hospitality they meet with is death and destruction from a whole neighborhood already in arms for their ruin."

There are three narrow-billed ducks that are called in Eastern waters "Sawbills," or "Sheldrakes." One is a buff-breasted bird, common enough in season on the sea-coast; another a red-breasted bird, that frequents inland waters much more than does the preceding; and the "Hooded" or "Black-and-white Sawbill." These are all very handsome species and of no value as food, being intolerably fishy. They enter into the list of what gunners call " trash ducks," and I do not wonder.

The Sheldrakes all breed in the northern regions, and in the United States are strictly migratory. Of the thirty-four or five species of ducks there are some few that are strictly marine, a few that never seek salt water, and the rest find themselves equally at home, whether along our coast, on our lakes, or following the tortuous courses of our many rivers.

In the Middle States the Mallard, Black Duck, the two Teal, the Widgeon, Sprig-tail, Golden-eye, and Wood-duck are all common to our inland waters, even going well upland and feeding on the mill-ponds.

Occasionally, wild ducks remain within the boundaries of the United States, but the great majority go into British America and nest in the northern wilderness. It is not improbable, however, that many of these birds, even so recently as two centuries ago, 
nested much southward of the present limits of their migrations in spring. Indefinite references to "wild fowl" in summer in old colonial records and travellers' journals and some manuscript records, seem to imply that many ducks were to be seen about our large watercourses during what is now their nesting season.

The single duck that may be said to be a fixed resident is the Wood-duck, and it is highly probable that these birds were once extremely abundant and went about in flocks. The mallard and black duck, the gadwall and possibly the teal were resident to

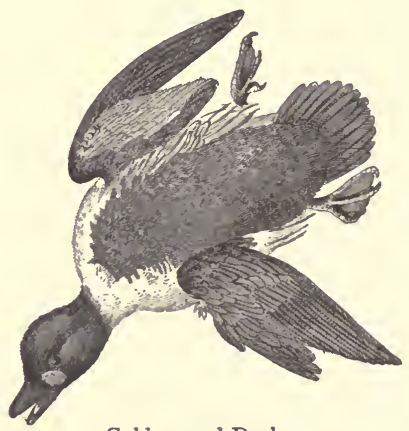

Golden-eyed Duck.

some extent in the seventeenth century, and the first two named are still found breeding south of Canada. That some non-mated ducks are always about, even in summer, is unquestionable. It occasionally happens that long after the migratory ducks have gone north, 
in spring, we have a high freshet in some river valley and a general flooding of the lowlands. At such a time single ducks of several species are very sure to make their appearance. I once spoke of this to an old gunner, and he told me that these "odd birds were mostly drakes." But where are they in ordinary stages of the water? They are not seen at all times, and so can scarcely be included with the "pensioners," or slightly wounded ducks we see occasionally in Chesapeake Bay,-birds just enough crippled not to be able to migrate.

When for some undeterminable reason wild ducks venture upon our rivers, close to the danger-line of a town's limits, they exercise a wonderful deal of ingenuity, and would not be detected by the ordinary passer-by. The keen-eyed duck-hunter spies them out occasionally and outwits them; but the tables are as often turned, and every one escape. It is really remarkable how many ducks come and go, up and down our rivers, unseen by the people living on the bank of the stream. The gunners bring into the town many a duck that is known only to the inhabitants as a dead bird; the living one they never saw; and yet a flock of ducks feeding on a broad expanse of water is well worth seeing. The glossy green heads of Mallards, the bald pates of Widgeon, the great loose-feathered topknot of a Butter-ball, the delicate gray plumage and tapering tail of a Sprig-tail, the parti-colored Shoveller, to gether, or singly, give a picturesqueness to some wide reach of the river that is worth a long journey to see. The extreme timidity of these birds makes this well- 
nigh impossible. The birds are all here, and at times many kinds are congregated, but they have learned from sad experience how dangerous it is to be abroad where man is, and so keep at a long distance. They feed early in the day or in the gloaming, and hide most effectually during the mid-day hours. This is as we find them on the Eastern rivers, but in the West, where they are always far more numerous, they lose much of this excessive caution, and as a consequence are slaughtered by the thousands.

The beautiful wood-duck is still abundant and has been able to hold its own, because of its timidity at certain seasons and ability to hide successfully in the smallest bits of cover. Scenting or hearing danger, it will disappear in a little clump of weeds, and if tracked by a dog, will dive and completely baffle the persistent spaniel. The nesting habits of the woodduck are thus described by Wilson:

"On the eighteenth of May I visited a tree containing the nest of a Summer-duck, on the banks of Tuckahoe River, New Jersey. It was an old grotesque white oak, whose top had been torn off by a storm. It stood on the declivity of the bank, about twenty yards from the water. In this hollow and broken top, and about six feet down on the soft decayed wood, lay thirteen eggs snugly covered with down, doubtless taken from the breast of the bird. . . .

"This tree had been occupied, probably by the same pair, for four successive years in breeding-time; the person who gave me the information, and whose house was within twenty or thirty yards of the tree, said that he had seen the female, the spring preceding, carry down thirteen young, one by one, in less than ten minutes. She caught them in her bill by the wing or back of the neck, and landed them safely at the foot of the tree, whence she afterwards led them to the water. Under this same tree, at the time I visited it, a large sloop lay on the stocks nearly finished, the deck was not more than twelve feet distant from the nest; yet notwithstanding the presence 
and noise of the workmen, the ducks would not abandon theil old breeding-place, but continued to pass out and in as if no person had been near. The male usually perched on an adjoining limb and kept watch while the female was laying, and also often while she was sitting. ...

"The Summer-duck seldom flies in flocks of more than three or four individuals together, and most commonly in pairs, or singly. The common note of the drake is peet, peet; but when, standing sentinel, he sees danger, he makes a noise not unlike the crowing of a young cock, oe eek / oe eek / Their food consists principally of acorns, seeds of the wild oats, and insects. . . .

"Among other gaudy feathers with which the Indians ornament the calumet, or pipe of peace, the skin of the head and neck of the Summer-duck is frequently seen covering the stem."

It is not strange that the wood-duck should have strongly attracted the attention of the Indians. Its wondrous beauty naturally appealed to a savage people fond of personal decoration and bright colors. They carved the head of this duck in steatite as an ornamental smoking-pipe, and we find it also moulded in clay in the elaborate pottery of the mound-builders.

Of our black duck, so common on inland waters as well as the " ponds" of our sea-coast marshes, Ord, the biographer of Wilson, remarks,-

"Of all our ducks this is perhaps the most sagacious and the most fearful of man. In the neighborhood of Philadelphia they are found in great numbers; they are, notwithstanding, hard to be obtained, in consequence of their extreme vigilance and their peculiar habits. During the day they chiefly abandon the marshes and float in considerable bodies on the Delaware, taking their repose with the usual precaution of employing wakeful sentinels to give notice of danger. In the evening they resort to the muddy flats and shores, and occupy themselves throughout the greater part of the night in seeking for food. When searching ont their feeding-grounds every individual is on the alert, and on the slightest appearance of an enemy the whole mount and scatter, in such a manner that in a flock of a hundred it 
would be difficult to knock down more than two or three at one shot. Their sense of smell is uncommonly acute, and their eyesight, if we may judge from their activity at night, must be better than that of most species. When wounded on the water they will immediately take to the shore, if in the vicinity, and conceal themselves under the first covert, so that one accustomed to this habit can have no difficulty in finding them."

Along the Atlantic seaboard the marine ducks, or such as are found in that region in abundance and but sparingly inland, are known as migratory birds now, whatever in the distant long ago might have been their breeding habits. Prominent among these are the " Red-head" and " Canvas-back," so highly prized as food ; the two "Broad-bills," the "Whistler," "Butter-ball," and Ruddy Duck. As sea-coast "fowl," spending their time in feeding where they can and eluding the gunners if they can, these birds do not present any marked habits that are of special interest. In the northwest some of these ducks breed within the limits of the United States, but now probably never do so south of the northern boundary of Maine, or in its northernmost counties.

The Eider-ducks, so well known for the down they provide, or rather are forced to yield up to man, are marine species, and yet occasionally have been met with as far inland as the Great Lakes. The Scoters, or "Coots," are three in number, that are found at sea along our sea-coast in autumn and winter. They are migratory, and in the west are found also on our large rivers and the lakes. They breed in the north. Of the American Scoter, as it is called, Wilson writes as follows, and the quotation will as well apply to the others as seen on our coast: 


\section{Ducks, Geese, and Swans.}

"This duck is but little known along our sea-coast, being more usually met with in the northern than southern districts, and only during the winter. Its food is shell-fish, for which it is almost perpetually diving. That small bivalve so often mentioned, small muscles, spout-fish, called on the coast razor-handles, young clams, etc., furnish it with abundant fare, and wherever these are plenty the Scoter is an occasional visitor. They swim, seemingly at ease, amidst the very roughest of the surf, but fly heavily along the surface and to no great distance. They rarely penetrate far up our rivers, but seem to prefer the neighborhood of the ocean, differing in this respect from the Cormorant, which often makes extensive visits to the interior." 


\section{CHAPTER XIII.}

PELICANS, CORMORANTS, AND PETRELS.

I T is a fact that probably but few have thought of, that, in the absence of all human testimony, we could build up a natural history of this country as it was just prior to the Columbian discovery. Possibly this record, based upon bones, would be as substantially correct as that which we are disposed to accept, based upon the vague references to animal life scattered through the "Journals" and "Records" of this and that early traveller in North America. Those who had the opportunity of seeing this country when, zoologically speaking, it was in its prime, seem one and all to have been especially unfitted for telling us what we now would like to know, and have left behind them details reflecting little credit upon themselves or their successors. The history of the Indian and wild life generally would be invaluable now, and what we have is rubbish. But the Indian has unintentionally left some records that go a good way in leading us to shrewdly guess the whole truth.

It is apparent to any one familiar with natural history that our Atlantic sea-coast and the valleys of our principal rivers that empty directly into the ocean are now sadly lacking in those bird-features that characterize the Pacific coast and the (until recently) 
Floridian peninsula. We have a few gulls even at our city wharves, but nothing more. This was not always the case. The records of innumerable feasts and countless camp-fires of the Indians remain in the mounds of shells, bones, and ashes that we find along the coast, and in the ash-pits and fire-sites in our river valleys. These tell of great birds in abundance ; but from June to October, I 893, anywhere from Maine to Maryland, were pelicans or cormorants really abundant, or even seen at all? Petrels we have, because they are yet beyond man's fiendish ingenuity to destroy, but not so of the large, sluggish sea-side and river-side dwellers. How utterly absurd it would have sounded in men's ears a century ago to have spoken of the possibility of exhausting the stock of food-fishes in the sea! Yet this is a subject that has received serious attention from legislative budies.

There is marked on an old map of New Jersey a stream flowing into the Delaware River that in the Indian tongue was known as Mechen-tsiholens sippu, or Big-bird Creek, and a bone of a pelican found in an ash-pit on the bank of that stream has always led me to think that this was the bird to which they referred, although not far away from the old Indian village was a spot in the river "that never freezes, and where swans do congregate." When, I wonder, was the last pelican seen on the Delaware, more than one hundred miles from its mouth? Dr. Turnbull says it " has been seen at rare intervals on the Delaware, and on the sea-coast near Cape May." Ridgway reports it " rare along the Atlantic coast of the United States." Dr. Warren states it to be very rare in Penn- 
sylvania, but mentions a sufficient number of instances of its being seen or shot to warrant my inference that at one time the pelican was not uncommon.

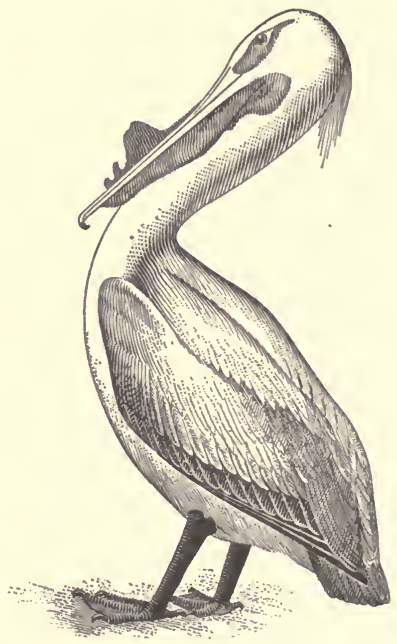

Pelican.

West of the Mississippi it is common. Dr. Coues says, "It formerly bred in immense numbers about Great Salt Lake, where it has decreased in abundance of late." Ridgway found it breeding " in vast bands" about Pyramid Lake in Nevada, the nest being merely a heaping up of the earth to a height of a few inches. Nuttall, quoting Richardson (the author of " Fauna 
Boreali-Americana"), states that in the fur countries they "deposit their eggs usually on small rocky islands on the banks of cascades where they can scarcely be approached, but still are by no means shy. They live together generally in flocks of from six to fourteen, and fly low and heavily, sometimes abreast, at others in an oblique line; and they are often seen to pass close over a building, or within a few yards of a party of men, without exhibiting any signs of fear."

Their food is fish principally, but other forms of animal life are not refused by them.

J. K. Lord, describing the white pelicans as he saw them in British Columbia, says, seeing for the first time their breeding-grounds, "Their nests were on the ground amidst the rushes, ... simply a confused heap of rushes with a lot of down and feathers in the centre. On the water these huge birds swim as easily, buoyantly, and gracefully as swans; and in fishing do not swoop down from a height as does the brown pelican, but thrust their heads under water and regularly spoon up small fish with their immense pouched beaks."

The Brown Pelican is said by Ridgway to belong properly to the "coasts and islands of the Gulf of Mexico and Caribbean Sea, including West Indies; north, regularly, to North Carolina." Beyond that all occurrence is "accidental," and I wish a great many more "accidents" would occur in the course of nature; it would 'liven up matters considerably.

Moseley, in his "Naturalist on the 'Challenger,' " says that as the ship steamed into the harbor of the 
island of St. Thomas "a number of brown pelicans were flying at a moderate height near the shore, and every now and then dashing down with closed wings into the water on their prey like gannets, their close allies. Often several of the birds dashed down together at the same instant." And again, "Flights of brown pelicans kept passing over our heads, flying always almost exactly over the same spot on their way from one feeding-ground to another. We shot a number of them as they flew over, at the desire of the German overseer of the farm where we had left our horses, who wanted the birds for eating. I should have thought a pelican to have been, next to a vulture, almost the least palatable of birds, but the man said they were very good."

In its habits generally this species does not materially differ from the preceding.

Within the boundaries of North America there are found five or six species of cormorants, and several varieties of one or more species. One of these, the Common Cormorant, or "Shag," is found in various parts of the world, Ridgway giving as its range "Europe, together with portions of Asia and Africa; Atlantic coast of North America, south, in winter, to coast of New Jersey." The Double-crested Cormorant is a strictly American species, belonging to "Northeastern North America, south, in winter, to Gulf coast, breeding from Northern United States northward." This latter species ranges extensively throughout the interior of the continent,- that is, in the Mississippi Valley. It was, like the pelican, once known to pass up the valley of the Delaware and 
Susquehanna, but is reported now by Dr. Warren to occur in Pennsylvania only on the lake-shore in Erie County. Dr. Turnbull says they are "rare;" many, however, pass along the coast to winter farther south.

As the cormorant feeds almost exclusively on fish, if not quite so, it is necessarily an expert swimmer and diver. It can remain a long time, too, under water. "The activity the bird displays under water is almost incredible to those who have not seen its performances, and in a shallow river scarcely a fish escapes its keen eyes and sudden turns, except by taking refuge under a stone or root, or in the mud that may be stirred up during the operation, and so avoiding observation."

This bird builds a conical nest of sticks with a depression at the top. In some localities this and the preceding are found nesting in the same place. They choose cliff-sides, surfaces of rocky islands, and sometimes trees. They are soon fouled by the excrement of the birds, and with the ground immediately surrounding "generally look as though bespattered with whitewash."

Moseley, in " Naturalist on the 'Challenger,' " gives the following amusing anecdote of a species of cormorant he saw in the South Pacific at Kerguelen Land.

"An idea of the relations of the various birds to one another in the siruggle for existence will be gained from the following incident : I saw a cormorant rise to the surface of the water, and lifting its head, make desperate efforts to gorge a small fish which it had caught, evidently knowing its danger, and in a fearful hurry to get it down. Before it could swallow its prey, down came a gull, snatched the fish after a light struggle, and carried it off to the rocks on the shore. Here a lot of other gulls immediately began to assert their right to a 
share, when down swooped a skua from aloft, right on to the heap of gulls, seized the fish, and swallowed it at once.

"The shag (cormorant) ought to learn to swallow under water, and the gull to devour its prey at once in the air. The skua is merely a gull which has developed itself by fighting for morsels."

On the Pacific coast are two well-marked species of cormorant, known respectively as the "Violet Green" and "Brandt's."

J. K. Townsend, in his "Narrative of a Journey across the Rocky Mountains to the Columbia River" (1839), says of the "Violet Green" species,-

"This most splendid of all the species of cormorants yet discovered inhabit - in considerable numbers the rocky cape at the entrance of the Columbia River, upon the sides of which it often rests, and no doubt rears its young within the natural cavities which front the tempestucus ocean, and in situations wholly inaccessible to man. Sometimes many weeks elapse in which not a single cormorant is seen, when suddenly a flock of fifty or sixty is observed to enter the bay, every individual of which immediately commences an assiduous search for the small fish and mollusca which constitute its food. It never ascends the river, but keeping almost constantly around the cape, under shelter of the enormous breakers which are incessantly dashing against it, successfully defies all attempts to shoot it. . . .

"The Indians of the Northwest coast make cloaks of the skins of this bird, sewed together. It is probably even more numerous to the north of Cape Disappointment, and must necessarily frequent less inaccessible places."

\section{Of Brandt's Cormorant the same author states, -}

"This species inhabits the Columbia River, and is not uncommon. It is seldom seen near the sea, but is mostly observed high up upon the river. It is, like most species of its genus, partially gregarious, and is fond of resting in company. The old trees which are fastened in the bottom of the river, and protrude above the surface, and the isolated rocks in the stream, are its favorite places of resort. Here it sits, sometimes for hours together, indolently gazing into the water, and only leaving its perch to seize an unsuspecting fish which 
may happen to pass near it. It is very shy and cautious, and is seldom killed even by the Indians, who are fond of its flesh."

In parts of Florida there is (or was?) found a curious cormorant-like bird, known locally as the "Water-turkey" and "Snake-bird." Ridgway gives its range as "the whole of tropical and subtropical America, north to South Carolina, Southern Illinois, and Western Mexico."

The following is George Ord's account, in part, as given in his edition of Wilson's "Ornithology :"

"It generally swims with its body immerged, especially when apprehensive of danger, its long neck extended above the surface, and vibrating in a peculiar manner. The first individual that $I$ saw in Florida was sneaking away to avoid me, along the shore of a reedy marsh, which was lined with alligators, and the first impression on my mind was that I beheld a snake; but the recollection of the habits of the bird soon undeceived me. On approaching it, it gradually sank, and my next view of it was at many fathoms' distance, its head merely out of the water. To pursue these birds at such times is useless, as they cannot be induced to rise, or even expose their bodies.

"Wherever the limbs of a tree project over, and dip into, the water, there the Darters are sure to be found, these situations being convenient resting-places for the purpose of sunning and preening themselves; and, probably, giving them a better opportunity, than when swimming, of observing their finny prey. They crawl from the water upon the limbs, and fix themselves in an upright position, which they maintain in the utmost silence. If there be foliage, or the long moss, they secrete themselves in it in such a manner that they cannot be perceived, unless one be close to them. When approached, they drop into the water with such surprising skill, that one is astonished how so large a body can plunge with so little noise, the agitation of the water being, apparently, not greater than that occasioned by the gliding of an eel."

To this account Ord added as follows, contributed by William Bartram : 
"Here is in this river, and in the waters all over Florida, a very curious and handsome bird, the people call them Snake-birds; I think I have seen paintings of them on the Clinese screens, and other Indian pictures; they seem to be a species of Colymbus, but far more beautiful and delicately formed than any other that I have ever seen. They delight to sit in little peaceable communities, on the dry limbs of trees, hanging over the still waters, with their wings and tails expanded, I suppose to cool and air themselves, when at the same time they behold their images in the watery mirror. At such times, when we approach them, they drop off the limbs into the water as if dead, and for a minute or two are not to be seen; when on a sudden, at a great distance, their long slender head and neck appear, like a snake rising erect out of the water; and no other part of them is to be seen when swimming, except sometimes the tip end of their tail. In the heat of the day they are seen in great numbers, sailing very high in the air, over lakes and rivers."

Under the general name of Petrel, which is a familiar one to all, are included a large number of birds, of which about twenty-five are found on the coasts of this continent. They are subdivided by reason of certain anatomical features into Fulmars, Shearwaters, and Petrels.

Of the Giant Fulmar, which occasionally reaches on the Pacific coast as far north as Oregon, Moseley states, based on observations made in the South Atlantic,-

"Whilst we were at work on the beach crowds of birds began to assemble, especially the Giant Petrel, or 'Breakbones,' the 'Nelly,' or 'Stinker,' of sealers. This bird in its habits is most remarkably like the vulture.

"It soars all day along the coast on the lookout for food. No sooner is an animal killed than numbers appear as if by magic, and the birds are evidently well acquainted with the usual proceedings of sealers, who kill the sea-elephant, take off the skin and blubber, and leave the carcass. They settled down here all round in groups, 
Pelicans, Cormorants, and Petrels. 26I

at a short distance, a dozen or so together, to wait, and began fighting amongst themselves, as if to settle which was to have first bite.

"The birds gorge themselves with food just like the vultures, and are then unable to fly."

In the North Atlantic there is a smaller species of these fulmars, known as the Noddy. It is a strictly arctic bird that comes southward as far as New England in winter. In its general habits it is said to be much the same as the "Breakbones" of the tropic seas.

The Shearwaters, of which there are several species, are strictly marine birds, their occurrence inland being so very rare that it has no significance. It is

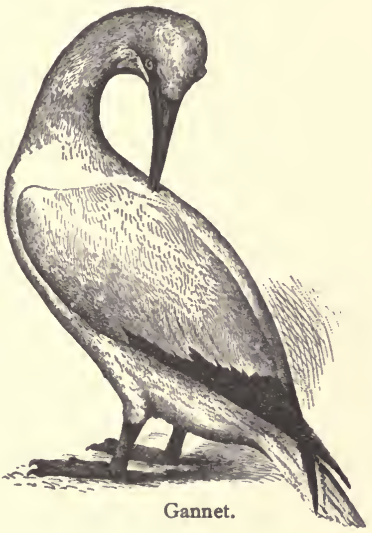
well known that a very strong wind and general storm brings many birds not usually seen even near shore, not only to the coast, but sometimes carries them inland for some miles. This, however, is very different from voluntarily leaving the open sea and following the course of some (to the bird) insignificant river. Nuttall says of them,-

"Their course in the air is exceedingly swift and powerful. With their long wings outstretched and almost motionless, they sweep over 
the wild waves, fearless of every danger, flying out in vast curves, watching at the same time intently for their finny prey. Like the Petrels, these Shearwaters are often seen to trip upon the water with extended feet and open wings; they likewise dive for small fish, and find an advantage in the storm, whose pellucid mountain waves bring to view the shiny prey to more advantage; the birds are therefore often seen most active at such times."

In a little island, an outlier of St. Thomas, Moseley found a species of this genus (Puffinus) "nesting in holes amongst the grass, laying a single, large white egg. The birds allowed themselves to be caught in the nest with the hand."

The Petrels, that we know so well, also, as Mother Carey's Chickens, are many in species, but do not differ materially in habits. Of such as come within the limits of North American waters, Ridgway mentions about a dozen, and a good many others, some of which may possibly get occasionally out of bounds; for these birds have, as Dr. Moseley has stated, "reduced the science of flight to the condition of a fine art." Storms occasionally drive them inland, but they never come voluntarily beyond the limits of salt water. It frequently happens that a single petrel will appear close astern of an outward-bound vessel and remain day after day at about the same distance from the steamer, and when the boat turns into port the petrel will suddenly disappear. I have not seen them follow the vessel far beyond the breakwater when it turned into Delaware Bay. Their flightpower is something wonderful.

Dr. Moseley says of the petrels,-

"They were our constant companions in the Southern Ocean, following the ship day after day, dropping behind at night to roost on 
the water, and tracing the ship up again in the early morning by the trail of the debris left in its wake."

\section{Wilson, writing of this habit, says,-}

"It is indeed an interesting sight to observe these little birds in a gale, coursing over the waves, down the declivities, up the ascents of the foaming surf that threatens to burst over their heads; sweeping along the hollow troughs of the sea, as in a sheltered valley, and again mounting with the rising billow, and, just above its surface, occasionally dropping their feet, which, striking the water, throw them up again with additional force; sometimes leaping, with both legs parallel, on the surface of the roughest wave for several yards at a time. Meanwhile they continue coursing from side to side of the ship's wake, making excursions far and wide, to the right and to the left, now a great way ahead, and now shooting astern for several hundred yards, returning again to the ship as if she were all the while stationary, though perhaps running at the rate of ten knots an hour I But the most singular peculiarity of this bird is its faculty of standing, and even running, on the surface of the water, which it performs with apparent facility. When any greasy matter is thrown overboard, these birds instantly collect around it, and facing to windward, with their long wings expanded and their webbed feet patting the water; the lightness of their bodies and the action of the wind on their wings enable them to do this with ease. In calm weather they perform the same manœuvre, by keeping their wings just so much in action as to prevent their feet from sinking below the surface."

On the Atlantic coast, the Wandering Albatross is said occasionally to reach northward as far as Florida; but there are other species that on the Pacific coast are quite common, as the "Black-footed" and "Shorttailed" species. The bird, however, is familiar by name to every one, and the reader of the "Ancient Mariner" has doubtless fancied, more or less correctly, what this strange bird is like.

Nuttall says of it,- 
"Like the Fulmar, the constant attendant upon the whale, the Albatross, no less adventurous and wandering, pursues the tracks of his finny prey from one hemisphere into another."

Dr. Moseley, already frequently quoted, found these birds nesting on Marion Island (South Pacific). The nests were on the ground, made of grass, moss, and earth, well compacted. The birds while sitting are extremely tame. They remained in this case when approached, and needed some stirring up with a stick to induce them to move.

Much has been written concerning the flight of the Albatross, and, indeed, this feature of its habits is much the most attractive, judging from what has been observed of the birds when not on the wing. Collingwood, in his "Rambles in the China Seas," says of the yellow-billed albatross, that they

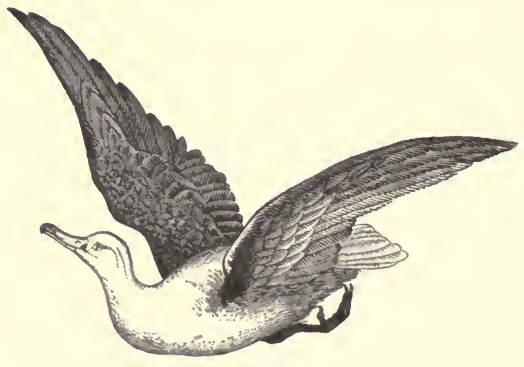

Albatross.

" are singularly graceful in their flight. They swim well and rapidly, and when leaving the water assist themselves to rise by their feet, running quickly for some distance along the surface until they are fairly above the water. How they propel themselves in the air 


\section{Pelicans, Cormorants, and Petrels. 265}

is difficult to understand, for they scarcely ever flap their wings, but sail gracefully along, swaying from side to side, sometimes skimming the water so closely that the point of one wing dips into it, then rising up like a boomerang into the air, then descending again, and flying with the wind or against it, apparently with equal facility. Now and then, but seldom, they give two rapid flaps with their wings, but to see this they must be watched."

\section{Dr. Moseley says, in regard to their flight,-}

"I believe that Albatrosses move their wings much oftener than is suspected. They often have the appearance of soaring for long periods after a ship without flapping their wings at all, but if they be very closely watched, very short but extremely quick motions of the wings may be detected. The appearance is rather as if the body of the bird dropped a very short distance and rose again. The movements cannot be seen at all unless the bird is exactly on a level with the eye. A very quick stroke, carried even through a very short arc, can of course supply a large store of fresh momentum. In perfectly calm weather Albatrosses flap heavily." 


\section{CHAPTER XIV.}

\section{GULLS AND TERNS.}

I $T$ is safe to say that whoever has seen a sea-coast has seen a sea-gull; and many a person who has spent all his days in an inland town may be likewise familiar with these birds, for they wander at times very far from the ocean, and are a feature of many a river valley almost as much as of the borders of the restless ocean. And whoever has seen has also heard the sea-gull, and will never forget the doleful creaking sound, so like that made by a rusty-hinged sign-board on a windy day. They are, whether seaward or inland, restless as swallows, but more deliberate in their flight and far less dainty in their habits. The floating carcass is as valued a morsel as the liveliest fish that swims.

The term "Gull" as commonly used includes a large number of birds, which the ornithologist tells us are not true gulls, but Skuas, Jaegers, and Kittiwakes. These differ anatomically, of course, from each other and the gulls proper, though in a general way, both in appearances and habits, they are essentially one; but the birds mentioned as not true gulls do not come inland to the same extent. We see a hundred gulls probably to one of the skuas or jaegers. These birds get the latter name, which means "hunter," from the fact that they are in a certain 
sense birds of prey. They attack other sea-birds and rob them of the food they have secured by honorable effort. This, of course, makes them overbearing, fierce, and like, in their ignoble features, our inland preying birds. These birds are in the northern hemisphere, largely confined to the arctic regions, coming southward in winter.

Moseley, writing of these birds as seen by him in the South Atlantic, says, "The skua is a gull which has acquired a sharp curved beak and sharp claws at the tips of its webbed toes. The birds are thoroughly predaceous in their habits, quartering their ground on the lookout for carrion, and assembling in numbers where there is anything killed in the same curious way as vultures." They not only rob the gulls, but one species eats birds, which they drag from their nests in the ground.

Of true gulls and their dainty cousins, the terns, there are nearly twoscore species. They are much alike in habits, yet vary exceedingly in size. In plumage, too, there is great variation; but notwithstanding this, there is a family likeness that is unmistakable. A tern is a small gull, and a gull an overgrown tern. The differences between Larus and Sterna are plain enough to the specialist, but do not stand out so prominently as to catch the eye of the casual observer. George Ord, in his edition of Wilson, referring to the advantages of seeing rather than reading of or hearing about birds, says of sea-gulls, -

"The zealous inquirer would find himself amply compensated for all his toil by observing these neat and clean birds coursing along the rivers and coast, enlivening the prospect by their airy movements : 
now skimming closely over the watery element, watching the motions of the surges, and now rising into the higher regions, sporting with the winds, while he inhaled the invigorating breezes of the ocean and listened to the soothing murmurs of its billows."

And of a well-known species, common to the Atlantic seaboard and our Eastern river valleys, he says,-

"The Laughing Gull, known in America by the name of the Black-headed Gull, is one of the most beautiful and most sociable of its genus. They make their appearance on the coast of New Jersey in the latter part of April, and do not fail to give notice of their arrival by their familiarity and loquacity. The inbabitants treat them with the same indifference that they manifest towards all those harmless birds which do not minister either to their appetite or their avarice, and hence the Black-heads may be seen in companies around the farm-house, coursing along the river-shores, gleaning up the refuse of the fishermen and the animal substances left by the tide; or scattered over the marshes and newly-ploughed fields, regaling on the worms, insects, and their larvæ, which, in the vernal season, the bounty of Nature provides for the sustenance of myriads of the feathered race.

"On the Jersey side of the Delaware Bay, in the neighborhood of Fishing Creek, about the middle of May, the Black-headed Gulls assemble in great multitudes, to feed upon the remains of the Kingcrabs which the hogs have left, or upon the spawn which those curious animals deposit in the sand, and which is scattered along the shore by the waves. At such times, if any one approach to disturb them, the Gulls will rise up in clouds, every individual squalling so loud that the roar may be heard at the distance of two or three miles.

"It is an interesting spectacle to behold this species when about recommencing their migrations. If the weather be calm, they will rise up in the air, spirally, chattering all the while to each other in the most sprightly manner, their notes at such times resembling the singing of a ben, but far louder, changing often into a haw, ha ha ha haw ! the last syllable lengthened out like the excessive laugh of a negro. When mounting and mingling together, like motes in the sunbeams, their black heads and wing-tips, and snow-white plumage, give them a very beautiful appearance. After gaining an immense 
height, they all move off, with one consent, in a direct line towards the point of their destination.

"This bird breeds in the marshes."

As in so many other instances, these birds are by no means as numerous now as when Ord wrote, more than sixty years ago, yet the bird is still here, but probably has altogether abandoned the great majority of its breeding-grounds in New Jersey and northward. Chamberlain says it has been driven away from Nantucket.

The Herring Gull of our coast-the Middle States -and of our harbors and rivers is well known to all. It follows up the Delaware to above Trenton, New Jersey, and Dr. Warren reports it on the Susquehanna, below Lancaster, Pennsylvania, and "is a rather common spring and fall migrant on Lake Erie."

Where, as along the sea-shore, there is ever so much to see, a single gull or even a flock of many birds attracts little attention. They pass up and down the coast, following the schools of fish or watching for such flotage as comes within their extended bill of fare. We glance at their glistening plumage, admire their graceful flight, and when they are out of sight they are straightway forgotten. But it is not so with the single gulls upon the river: they are too prominent here to be passed by unheeded. It occasionally happens that we have a storm that drives the gulls inland (and such storms drive people in-doors too much), and the river that was monotonous yesterday is almost tumultuous to-day. The wind-tossed waves, the cloud-flecked sky, the roar of gusty blasts in the leafless trees, the wild clamor of 
excited crows, the screaming of the gulls,- - these make a morning worth seeing; it is a day that thrills, and we go back, as it were, to a time when the river and the valley were fresh and new. These are the sights and sounds that we are occasionally treated to now; but now they are the exception, the time was when they were the rule. We are reduced now to two species of gulls and not many of them; but when the old travellers of two centuries ago were exploring this river (how strangely that sounds to us!) they saw sights that have now forever passed away. When Dankers and Sluyter went from Trenton (Falls of Delaware) to Chester, Pennsylvania, and had to row their boat sometimes against tide, the gulls followed them, I think, as they will now keep astern of a tugboat, watching for scraps.

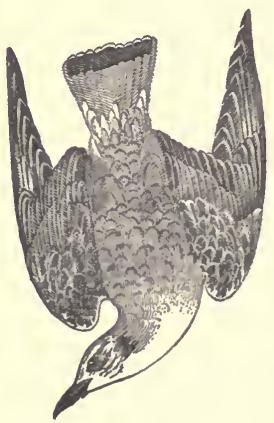

Gull. Perhaps they saw a pelican on the shore, or a crane; they did not fail to start from their fishing-grounds whole troops of herons, blue and white, large and small, and all noisy as a modern convention.

It is seldom that the upriver gulls ever go far inland, and when they do, it is only to sail high up in the air, and so within sight of the open water. I refer now to the Herring Gull. Occasionally the Blackheaded Gull will throng the flood-meadows when 
there is a spring freshet, and these not only fly low, but walk about the grassy meadows that are out of water as if they were within hearing of old ocean and feeding in the salt marsh.

" Gulls are shy birds, and are caught with difficulty. They fly in flocks, and carry on their fishing avocations in the sea near the shore. Sometimes they cover the rocks, and when disturbed they rise with frightened screams. Occasionally, they may be observed on the shore, crouched with wings half extended, and apparently enjoying the warmth of the sand. They walk with a most dignified carriage. On water they swim with ease, but seldom dive, preferring to take their prey as it appears at the surface. In the air they fly slowly yet gracefully, and often sweep in circles, as if displaying their agility. The web-footed birds glory in the agitations of the sea; nothing gives them so much delight as a violent storm, for instinct or experience has taught them that a storm casts up the mollusks and other of the sea inhabitants which are usually beyond their reach, and brings them to the surface or leaves them on the beach.

"How often, as we have watched the horizon darken and the storm-clouds gather, have we marked the striking contrast as the white gulls and sea-swallows now rose and now fell above the waves, waiting in eager expectation for their coming feast!"-MoQuiNTANDON.

The Sea-swallows, or Terns, are seemingly all that a bird should be: beautiful in plumage, graceful in movement, gentle, and absolutely incapable of doing any harm; yet we read of their practical extermination in some localities because of a demand for their wings to trim hats. The people that are guilty of such monstrous cruelty are fiends, whether the men who shoot, the men who buy, or the women that wear these beautiful birds.

Terns are somewhat more marine in their habits than the gulls. They less seldom, I think, come inland and do not remain day after day, when chance 
brings them from the sea-coast to the river. In migratorial movements they are found inland occasionally, and two species are known to our larger watercourses and the lakes. The name sea-swallow is peculiarly fitting to these birds, as they are forever in the air. They do not dip down and swim for a while, but keep watch from above and plunge down, straight as an arrow, into the water. Terns, because they fly with their beaks pointed straight down, have been likened to huge mosquitoes, which is hardly fair to the birds, for they do not play any of the mean parts that go to make up the insect's despicable existence.

There are some fourteen or more terns found on the sea-coast of North America, and they are pretty well distributed, no one locality having more than a fair share. They mostly feed on fish, are gregarious, and when nesting prefer to do so in company with others of their own kind, or with other and larger birds. They utter sharp, shrill cries, and accompany these with a threatening click of the bill when you approach too near their nests, which, on the Jersey coast, are on the ground, sometimes with a bit of dead grass or sea-weed, but as often a mere bare depression in the sand. I have sometimes wondered how it was that the nests were not destroyed by the winds, as I have found many on sandy beaches where the sands were forever shifting, and seemed to threaten the burial of both birds and eggs.

The Common Tern, which is known by a long series of names, as "Wilson's Tern," "Summer Gull," and "Mackerel Gull," is found in Europe as well as in this country, and wanders into the forbidding 
regions of the far north. It has no fancy, however, for extremely cold weather, and winters in a mild climate. We see them first in mid-spring, and they nest along our Atlantic seaboard.

\section{Wilson's account is as follows :}

"About the middle or twentieth of May this bird commences laying. The preparation of a nest, which costs most other birds so much time and ingenuity, is here altogether dispensed with. The eggs, generally three in number, are placed on the surface of the dry drift grass, on the beach or salt marsh, and covered by the female only during the night, or in wet, raw, or stormy weather. At all other times the hatching of them is left to the heat of the sun. These eggs measure an inch and three-quarters in length by about an inch and two-tenths in width, and are of a yellowish dun color, sprinkled with dark brown and pale Indian ink. Notwithstanding they seem thus negligently abandoned during the day, it is very different in reality. One or both of the parents are generally fishing within view of the place, and on the near approach of any person, instantly make their appearance overhead, uttering a hoarse jarring kind of cry, and flying about with evident symptoms of great anxiety and consternation. The young are generally produced at intervals of a day or so from each other, and are regularly and abundantly fed for several weeks, before their wings are sufficiently grown to enable them to fly. At first the parents alight with the fish, which they have brought in their mouth, or in their bill, and tearing it in pieces, distribute it in such portions as their young are able to swallow. Afterwards they frequently feed them without alighting, as they skim over the spot; and as the young become nearly ready to fly, they drop the fish among them, where the strongest and most active has the best chance to gobble it up. In the mean time, the young themselves frequently search about the marshes, generally not far apart, for insects of various kinds; but so well acquainted are they with the peculiar language of their parents, that warn them of the approach of an enemy, that on hearing their cries they instantly squat, and remain motionless until the danger be over."

Of the other terns little need be said. Their habits do not vary sufficiently from what has already 
been said of the species that is so well known to those who, during summer, tarry at the sea-shore.

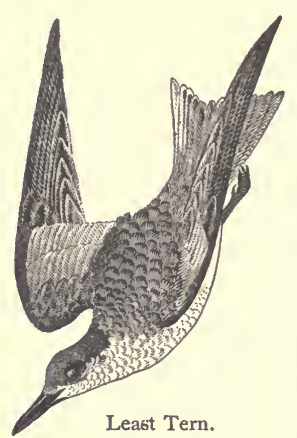

But a word concerning the Least Tern, and this, too, from Wilson:

“This beautiful little species looks like the preceding in miniature, but surpasses it far in the rich, glossy, satin-like white plumage with which its throat, breast, and whole lower parts are covered. Like the former, it is also a bird of passage, but is said not to extend its migrations to so high a northern latitude, being more delicate and susceptible of cold. It arrives on the coast somewhat later than the other, but in equal and perhaps greater numbers; coasts along the shores and also over the pools in the salt marshes in search of prawns, of which it is particularly fond; hovers, suspended in the air, for a few moments above its prey exactly in the manner of some of our small Hawks, and dashes headlong down into the water after it, generally seizing it with its bill; mounts instantly again to the same height, and moves slowly along as before, eagerly examining the surface below."

Wilson visited, in Cape May County, New Jersey, a spot where these birds were nesting, and describes his experiences as follows :

"During my whole stay these birds flew in crowds around me, and often within a few yards of my head, squeaking like so many young pigs, which their voice strikingly resembles. A Hummingbird, that had accidentally strayed to the place, appeared suddenly among this outrageous group, several of whom darted angrily at him; but he shot like an arrow from them, directing his flight straight towards the ocean. I have no doubt but the distressing cries of the 
Terns had drawn this little creature to the scene, having frequently witnessed his anxious curiosity on similar occasions in the woods.

"The Lesser Tern feeds on beetles, crickets, spiders, and other insects, which it picks up from the marshes, as well as on small fish."

The Skimmer, Razor-bill or Cut-water, is a most curious bird that comes from southern waters late in spring as far north as New Jersey, but seldom continues beyond Sandy Hook. Of course, southward, it is seen earlier. As in the case of probably every species of sea-bird nesting on the ground, these skimmers are now far less numerous than when Wilson studied them in the marshes of Cape May. During a long stay in that neighborhood, with excellent opportunities to see what birds were then about, in 1892 , I saw but one specimen, and that my guide could give me no name for or information about. $\mathrm{He}$ had seldom seen them. Wilson tells us that this bird

" is most frequently seen skimming close along shore, about the first of the flood, at which time the young fry, shrimp, etc., are most abundant in such places. There are also numerous inlets among the low islands between the sea-beach and main land of Cape May where I have observed the Shearwaters, eight or ten in company, passing and repassing at high water particular estuaries of those creeks that run up into the salt marshes, dipping, with extended neck, their open bills into the water, with as much apparent ease as Swallows glean up flies from the surface. On examining the stomachs of several of these, shot at the time, they contained numbers of a small fish. . . .

"The voice is harsh and screaming, resembling that of the Tern, but stronger. It flies with a slowly flapping flight, dipping occasionally, with steady expanded wings and bended neck, its lower mandible into the sea, and with open mouth receiving its food as it ploughs along the surface. It is rarely seen swimming on the water, but frequently rests in large parties on the sand-bars at low water. One of these birds which I wounded in the wing, and kept in a room beside me for 
several days, soon became tame and even familiar. It generally stood with its legs erect, its body horizontal, and its neck rather extended. It frequently reposed on its belly, and stretching its neck, rested its long bill on the floor. It spent most of its time in this way, or in dressing and arranging its plumage with its long scissors-like bill, which it seemed to perform with great ease and dexterity. It refused every kind of food offered it, and I am persuaded never feeds but when on the wing."

Dr. Coues says that these birds go in true flocks, and not mere loose assemblages like terns, and that they are largely nocturnal or crepuscular. "Their mode of feeding is not exactly made out, but it is believed they skim over the surface with the body inclined downward, the bill open, and the under mandible in the water, so they really take their prey in a manner analogous to the feeding of whales." 


\section{CHAPTER XV.}

THE DIVING BIRDS.

THIS group consists of the Auks, Murres, Guillemots, Auklets, Puffins, Loons, and Grebes. Of the five subgroups mentioned in order, none belong inland, but of course "stragglers" of some of them have been carried inland, and so swell the lists of birds found in such and such a locality. The loons and grebes, on the other hand, are quite at home in fresh water, and add no little to the charm of many a watery waste that is now pretty closely shorn of the features designed for it by Nature.

The Great Auk is extinct. Nature had nothing to do with its destruction. Comment is unnecessary. The Little Auk survives and seems equal to holding its own, the odds not being so decidedly against it. In winter they come as far south as the New Jersey coast. The late Dr. Lockwood has given an amusing account of one of these birds that was kept for some time in confinement. It was one of many that in the winter of 1877 not only appeared upon the coast, but came inland. "They were so gentle and unsuspicious, and so comical, for on the land their gait was a tipsy waddle." One was picked up six miles from sea, and entirely beyond tidal reach. It was ill at ease in the air of a close room, standing upright on 
the floor, but when offered a tub of water, "seemed crazed with delight. It dived and splashed, but was puzzled by its close quarters, and could not realize that the tub's sides were so inconveniently near."

"There is much," says Dr. Lockwood, "to wonder at and to admire in the sea-dove's ways when in her own element. .... When it suits they can ride the crest like the stormy petrel. But see! that gorgeous wave approaching, and that Dovekie goes right through it as an arrow through a cloud of smoke. ... It can float like a bubble and progress like a shot."

The Guillemots are entirely marine, according to Nuttall, but the inevitable river stragglers have occasionally turned up. They are arctic birds that wander southward in winter and are not abundant at any time, even off the coast. They are strong flyers, moving rapidly in direct lines, and at but a slight distance above the water. They are expert divers, and move under the water with much rapidity. They feed on crustaceans, fish, and such animal food as comes in their way. They are commonly known as Sea-pigeons.

The Puffin, which is at once recognized by its enormous box-like beak, is another of the arctic birds, or semi-arctic, that wanders down the Atlantic coast in winter as far south as New Jersey. One is said to have been killed on the Delaware River near Philadelphia in 1876 . Occasionally they have been found a few miles inland in New Jersey after an unusually violent storm.

Of the Divers, or Loons, and Grebes we have 


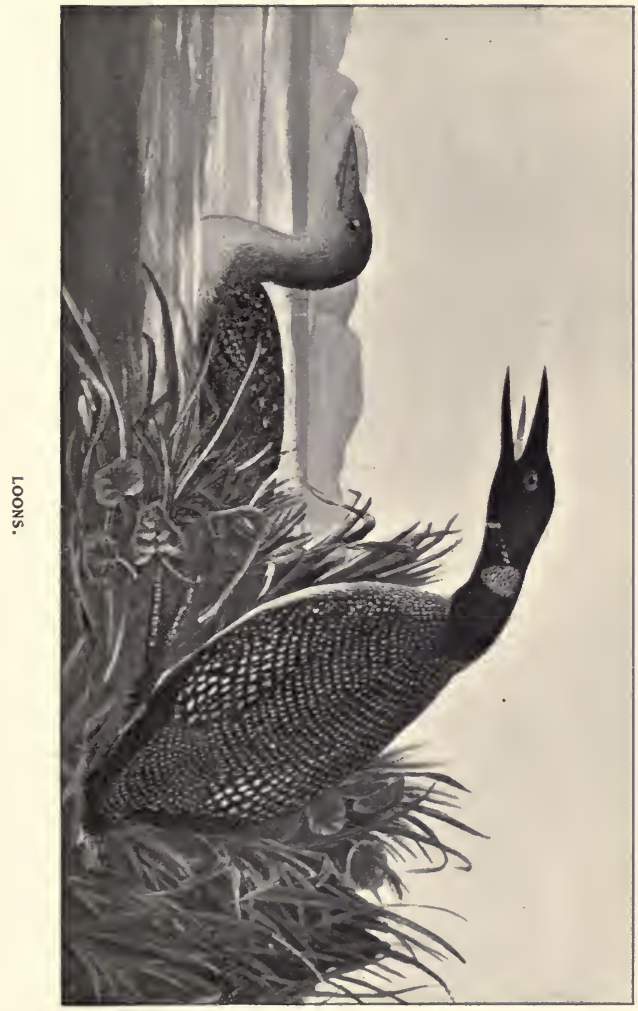



eleven species. Of these, the Red-throated Loon is not common in the Middle States, but is found along the coast. It breeds in the far north. It has been found on the Delaware in midwinter (young birds), and probably was carried by strong winds across the State, rather than followed up the course of the river from its mouth.

The Loon, or "Great Northern Diver," by which name it appears to be known only in the books, is black and white and as big as a goose. Once seen, therefore, it cannot be mistaken. It is a migratory bird principally, but breeds in the United States, along the northern tier of States. But its migratory movements are not very regular,- that is, the lines of its travel may vary a little; and of one matter concerning them there can be no doubt: they do not all go northward to spend the summer. The loon is seen on the upper Delaware River, sparingly, every summer. In 1893 I saw them in tide-water as late as June (first week), and again in the first week of September.

\section{George Ord says,-}

"The Loon is restless before a storm; and an experienced master of a coasting vessel informed me that he always knew when a tempest was approaching by the cry of this bird, which is very shrill, and may be heard at the distance of a mile or more. The correctness of this observation I have myself since experienced in a winter voyage on the southern coasts of the United States."

Occasionally the loons will leave the rivers and take up their quarters in some retired mill-pond. Of course they are soon discovered and shot at until killed or worried to death. Such loons have their 
revenge at times. A miller told me of a "speckled goose" he had shot, and invited some friends to share the subsequent feast with him. "It was the meanest goose I ever tackled," was his concluding remark.

In autumn, sometimes during the winter, and again in early spring, there are seen upon our rivers and larger ponds active duck-like birds, that swim away from you rapidly if they think they are being watched, and dive with startling suddenness if you attempt to chase them. They are literally quick as a flash, and dodge the coming charge of shot unless it happens that your aim was not good, which is very probable. These birds are pretty, and occasionally when they rise up from the water and flap their wings they show a silvery glistening breast that is very beautiful. These birds are migrants and seek the far north to breed, but are found with us off and on for nearly nine months of each year. They are typical divers. One of them-Holboell's Grebe-is rare in the Middle States, but by no means unknown to the Delaware Valley; the other is the Horned Grebe, and is more frequently seen. Dr. Coues "found it breeding at various points in Northern Dakota, as along the Red River, in the prairie sloughs, with Coots, Phalaropes, and various Ducks, and in pools about the base of Turtle Mountain in company with $P$. californicus and the Dabchick."

This Dabchick, or Devil-diver, is so plain a bird and so generally insignificant that it comes and goes without causing the slightest ripple either on the water or in our minds; yet the little fellow is cunning and a real attraction to our mill-ponds, where it 
seems more at home than on the river. This diver, or grebe, is a strictly American species, but no one of our writers appears to have grown enthusiastic over it. It is one of my favorites, for it is fearless and comes directly into town, and takes genuine delight in dodging the stones that boys will throw at it on every occasion. It is not deterred from swimming in the streams of its forefathers, even though befouled with factory refuse. Again, it will keep you company, when paddling about in the solitary crooks and turns of little inland creeks, keeping you in sight, but never in your way; lively by action, but uttering no useless words; a type of companion hard enough to find among the unfeathered bipeds.

This completes the undertaking as outlined in the opening pages. I promised to conclude with the Dabchick and have done so; but one duty remains: to beg the Diver's pardon for speaking ill of it when thinking of the tuneful thrushes. I trust what I have said in proper place will make amends for the unintentional slight; and now I have but to hope that this glance at North American bird-life will aid in bringing about a proper feeling for all our birds,a feeling that will induce us all to make serious efforts to check the persecution to which they are subjected. It will be a sorry day when the ornithological literature of our country will be classed by librarians as a department of Ancient History. 



\section{N DEX.}

\section{A.}

Accentors, 65 .

Albatross, 263.

Auk, Great, 277.

Little, 277.

Auklets, 277.

Auks, 277.

Avocet, 202.

B.

Bittern, 223.

Least, 225.

Blackbird, Brewer's, 135 .

Red-winged, 29, 49, 129.

Sheep, 127.

Yellow-headed, 128.

Bluebird, 31, 52, II5.

Bobolink, I26.

Bob-white, 52, 187.

Breakbones, 260.

Bunting, Beautiful, IIr.

Black-throated, III.

Lazuli, III.

Painted, III.

Varied, III.

Butcher-birds, 74 .

Butter-ball, 247.

c.

Canary, ro3.

Cat-bird, 50, 52, 68, 121 .

Cedar-bird, 75 .

Chat, Yellow-breasted, 56, 63 .

Chatterer, Bohemian, 76.
Chebec, 118.

Chewink, 68, 105.

Chickadee, 37.

Chimney-swallow, 140.

Chippy, 95, 99.

Chuck-will's-widow, 140 .

Cock of the Plains, I93.

Coot, 237.

Cormorant, Brandt's, 258.

Common, 256.

Double-crested, 256.

Violet-green, 258.

Cow-bird, 127.

Bronzed, 128.

Cow-bunting, 127.

Crane, Brown, 232.

Sandhill, 232.

Whooping, 23 r.

Cross-bills, 91.

Crow, 125 .

Fish, 125.

Crow-blackbird, 135 .

Cuckoo, Black-billed, I54. Ground, 154.

Yellow-billed, 154, 156.

D.

Dabchick, 280.

Darter, 259.

Devil-diver, 280.

Dickcissal, 1 II.

Dipper, American, 53.

Dove, Ground, 197.

Turtle, 187, 196.

Duck, Black, 245, 249. 
Duck, Broad-billed, 250.

Canvas-back, 250.

Eider, 250.

Golden-eyed, 245 .

Red-headed, 250.

Ruddy, 250.

Sprig-tailed, 245 .

Whistler, 250.

Wood, 246.

E.

Eagle, Bald, 172.

Golden, 172.

Egret, American, 228.

Euphonia, Blue-headed, 84.

\section{F.}

Falcon, Peregrine, I74.

Winter, 170.

Feather-boots, I7r.

Finch, Foxie, 104.

Grass, 95.

Grasshopper, 96.

Indigo, 88, 1 10.

Purple, 90.

Sea-side, 97.

Sharp-tailed, 96 .

Fire-robin, 133 .

Flicker, Golden-winged, 152.

Flood-gull, 215.

Flycatcher, Acadian, 117.

Fork-tailed, II3.

Great-crested, II4.

Least, II8.

Olive-sided, 116 .

Say's, Ir5.

Traill's, 118.

Yellow-bellied, II7.

Flycatchers, Tyrant, II3.

Flysnapper, 75.

Fly-up-the-Creek, 228.

Fulmar, Giant, 260.
G.

Gallinule, Florida, 236.

Purple, 236.

Gannet, 26r.

Gnatcatcher, Blue-gray, 32.

Goatsuckers, 138.

Golden-gabbler, 133 .

Goose, Brant, 244.

Canada, 244.

Snow, 244.

White-fronted, 244

Goshawk, 168 .

Grakle, Purple, 49, 135 .

Rusty, I35.

Grass Plover, 209.

Grebe, Holboell's, 280.

Horned, 280.

Grebes, 277.

Greenlets, 67.

Grosbeak, Black-headed, IIO.

Blue, Iro.

Cardinal, 107.

Evening, 89.

Pine, 96.

Rose-breasted, II, 78, rog.

Grouse, Canada, 189.

Dusky, 189.

Pinnated, 192.

Ruffed, 189.

Sharp-tailed, 193.

Guillemots, 277.

Gull, Black-headed, 268.

Herring, 269.

Laughing, 268.

Mackerel, 272.

Summer, 272.

Gyrfalcon, 174.

H.

Hang-nest, 133.

Hawk, Black, 17x.

Broad-winged, 170. 
Hawk, Chicken, 168.

Cooper's, 168.

Duck, 174.

Fish, 176.

Marsh, 166 .

Red-shouldered, 170.

Red-tailed, I69.

Sharp-shinned, 167.

Sparrow, 49, 175 .

Hawks, 165.

Hazel-hen, 240.

Heron, Great Blue, 227.

Green, 228.

Little Blue, 227.

Night, 229.

Yellow-crowned, 23 I.

Snowy, 228.

High-hole, 152.

Humming-bird, 8I, I4I.

I.

Ibis, Glossy, 222.

Scarlet, 221.

White, 221.

Wood, 223.

\section{J.}

Jaegers, 266.

Jay, Blue, 52, I2I.

Canada, I22.

Steller's, 123.

K.

King-bird, II4.

Kingfisher, Common, 157.

Texan, 157 .

Kinglet, Golden-crowned, 33.

Ruby-crowned, 33.

Kite, Blue, 165.

Everglade, 166.

Swallow-tailed, 165.

Kittiwakes, 266.
L.

Lark, Horned, II9.

Meadow, I3I.

Western, I32.

Linnets, 92.

Lobe-foot, 202.

Long-spur, Lapland, 88, 94 .

Loon, 279.

Loons, 277.

M.

Magpie, I2x.

Mallard, 245.

Martin, 77.

Mocking-bird, 5 I.

Moose-bird, 122.

Mother Carey's Chickens, 262.

Motmots, 157.

Murres, 277.

Myrtle-bird, 5 I.

N.

Night-hawk, I39.

Noddy, 26r.

Nut-cracker, Clarke's, I26.

Nuthatch, White-bellied, 35.

Red-bellied, 35 .

O.

Oriole, Baltimore, I53.

Orchard, I34.

Orioles, r33.

Ortolan, $\mathbf{2} 6$.

Ouzel, 53.

Oven-birds, 56,65 .

Owl, Acadian, I8I.

Barn, I78.

Barred, r8o.

Burrowing, 184 .

Cat, 179.

Great Gray, 18r. 
Owl, Great Horned, I83.

Q.

Hawk, I84.

Little Red, II4, 182.

Long-eared, 179.

Pygmy, r85.

Short-eared, 180.

Snowy, I83.

Owls, I78.

Oyster-catchers, 215.

\section{P.}

Paroquet, Carolina, I58.

Partridge, Mountain, I88.

Peabody-bird, 98.

Pelican, 253.

Brown, 255.

Petrel, 262.

Pewee, 54, II5.

Wood, I 6.

Phalarope, Red, 20I.

Wilson's, 202.

Phalaropes, 201.

Phœebe-bird, xx5.

Black, II5.

Pigeon, Passenger, I94.

Wild, I87.

Pigeon-hawk, 168.

Pine-finch, 93.

Pine-linnet, 93.

Pine-siskin, 93.

Pipilo, 106.

Pipit, Sprague's, 55.

Plover, Black-bellied, 2 I I.

Golden, 2 I I.

Killdeer, 214.

Piping, 212.

Semi-palmated, 212.

Wilson's, 212.

Prairie-chicken, I92.

Ptarmigan, Willow, rg2.

Puffins, 277.
Quail, 187.

Head, 96.

R.

Rail, Clapper, 233.

King, 234.

Virginia, 235.

Yellow-breasted, 236.

Raven, I23.

White-necked, I24.

Razor-bill, 275.

Red-bird, Cardinal, II, 52.

Summer, 84, 107.

Winter, I07.

Redpolls, 92.

Redstart, 6r.

Reed-bird, 126.

Rice-bird, 126.

Robin, 29, 52.

Swamp, 26.

Rut-runner, 95.

S.

Sand-piper, Least, 2 II.

Semi-palmated, 2 II.

Solitary, 208.

Spotted, 54, 207.

Sapsucker, 144.

Yellow-bellied, 147.

Sawbills, 245.

Scoter, 250.

Sea-swallow, 27 r.

Shearwater, 26r.

Sheep Blackbird, I27.

Sheldrakes, 245.

Shrike, Great Northern, 74.

Loggerhead, 74.

Shrikes, 74.

Skimmer, 275.

Skua, 266. 
Snake-bird, 259.

Snipe, 205.

English, 205.

Gray, 205.

Robin, 205.

Wilson's, 205.

Snow-bird, 88, rov.

Snow-bunting, 93.

Snow-flake, 88, 93.

Sora, 235.

Sparrow, English, 4I, 78.

Field, 99.

Marsh, 82, I02.

Song, rul.

Swamp, 102.

Tree, 98.

Vesper, 95.

White-crowned, 97.

White-throated, 98.

Spoon-bill, 220.

Stilt, 202.

Swallow, Bank, 77, 80.

Barn, 77, 82.

Chimney, 140 .

Cliff, 77, 79.

Crescent, 79.

Eave, 79.

Rocky Mountain, 79.

Rough-winged, 77, 83 .

Violet-green, 77.

White-bellied, 77, 82.

Swallows, 54, 77.

Swamp-robin, 26.

Swan, Trumpeter, 242.

Whistling, 242.

Swift, 140.

T.

Tanager, Hepatic, 84 .

Louisiana, 84.

Scarlet, II, 84

Teal, 245.
Tern, Least, 274.

Wilson's, 271.

Thrasher, 48, 52 .

Thrush, Hermit, 26.

Olive-backed, 28.

Swainson's, 28.

Varied, 30.

Wood, 24.

Titlark, 55 .

Titmouse, Black-capped, 37 .

Crested, 38, 44.

Tree-creeper, Brown, 39.

Tricolors, 131.

Trogons, 157.

Troopial, Yellow-headed, 129.

Turkey, Wild, I94, 240.

Turkey-buzzard, 162.

Turnstone, 215.

Turtle-dove, 196.

\section{v.}

Veery, 25.

Vireo, Red-eyed, 68.

Warbling, 68, 72.

White-eyed, 68, 70 .

Yellow-throated, 68.

Vulture, Black, I6r.

w.

Wagtails, 65.

Warbler, Black and White Tree. creeping, 60 .

Black-throated Green, 58.

Hooded, 60.

Parula, 60.

Summer, 58.

Worm-eating, 60.

Yellow Red-poll, 57.

Yellow Rumped, 59.

Warblers, 55.

Water-thrushes, 56,65 .

Water-turkey, 259. 


\section{INDEX.}

Waxwing, 76.

Whippoorwill, 52, 138.

Whiskey Jack, 122.

Widgeon, 245.

Woodcock, 203.

Woodpecker, Arctic Three-toed, 146.

Downy, 144 .

Hairy, 144.

Ivory-billed, 144.

Pileated, 149.

Red-bellied, 151.

Red-cockaded, 146 .

Red-headed, 150.
Woodpeckers, 52, I15, 143.

Wood-robin, 52.

Wood-warblers, 56.

Wren, Bewick's, 46.

Cactus, 46.

Carolina, 44.

House, 4I.

Marsh, 47, 82.

Winter, 43,54 .

$\mathbf{Y}$.

Yellow-birds, 93.

Yellow-throat, Maryland, 62 




ำ

学等

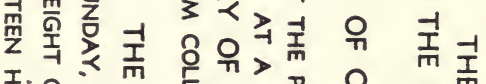

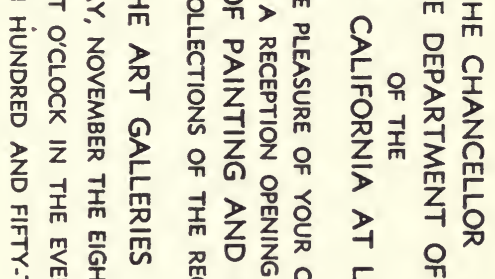

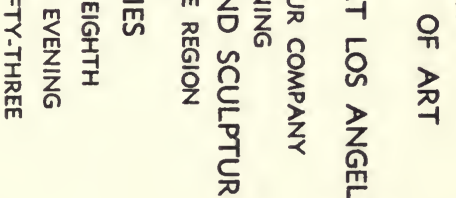




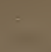

$-$

$=$

in

둥

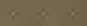

둘

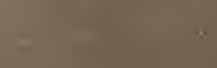

a. 